\author{
UNIVERSIDADE DE SÃO PAULO \\ FACULDADE DE FILOSOFIA, LETRAS E CIÊNCIAS HUMANAS \\ DEPARTAMENTO DE GEOGRAFIA \\ PROGRAMA DE PÓS-GRADUAÇÃO EM GEOGRAFIA FÍSICA
}

\title{
DELIMITAÇÃO DE UNIDADES CLIMÁTICAS LOCAIS NO PARQUE NACIONAL CAVERNAS DO PERUAÇU
}

Sérgio Serafini Júnior

Dissertação apresentada ao Programa de Pós-Graduação em Geografia Física, do Departamento de Geografia da Faculdade de Filosofia, Letras e Ciências Humanas da Universidade de São Paulo, para obtenção do título de Mestre em Climatologia.

(VERSÃO REVISADA)

Orientador: Prof. Dr. José Bueno Conti 
DEDICATÓRIA...

Dedico aos grandes amores da minha vida....; meus filhos Pedro, Isadora e Vitória e minha esposa

Valéria. 
O RESUMO

O Parque Nacional Cavernas do Peruaçu constitui-se numa Unidade de Conservação localizada ao norte de Minas Gerais, abrangendo parte dos municípios de Januária, Itacarambi e São João das Missões, totalizando uma área de 56.000 ha.

Atravessado pelo curso médio do rio Peruaçu, esta Unidade de Conservação é considerada uma das regiões cársticas mais importantes do Estado de Minas Gerais por agregar um enorme valor científico para a arqueologia e paleontologia, contendo inúmeros sítios arqueológicos e espeleológicos, com representações rupestres e material fóssil, contribuindo assim, para as principais áreas de pesquisa científica realizadas na área.

Além da notória importância arqueológica e paleontológica, o Parque Nacional Cavernas do Peruaçu é, também, uma área que reserva com bastante riqueza elementos naturais físicos e bióticos que, associados às características atuais dos padrões de uso e ocupação do solo, configuram-se como unidades de paisagem segundo a perspectiva geossistêmica emoldurada por BERTRAND (1971) para a escala de análise local.

Com base na identificação e delimitação dessas unidades de paisagem, a proposta deste trabalho foi registrar os dados de temperatura e umidade relativa do ar em cada uma destas unidades de modo a permitir a montagem de um banco de dados relacional onde fosse possível associar a variação climática destes atributos à variação fisionômica de cada um dos ambientes abordados.

Considerando a variação da temperatura e umidade relativa do ar em relação ás unidades de paisagem, foi possível delimitar as unidades climáticas locais do Parque Nacional Cavernas do Peruaçu, apontando os valores limites entre cada uma delas.

\section{PALAVRAS-CHAVE}

Peruaçu, Climatologia, Clima local, Paisagem, Geossistema. 


\begin{abstract}
Peruaçu's Caves National Park constitutes in a Unit of Preservation located in the north of Minas Gerais, embracing part of Januária's Municipal districts, Itacarambi and São João das Missões, totalizing an area of 56.000 ha.

Crossed by the average course of the Peruaçu river, this Unit of Preservation is considered one of the most important karstic regions of the Minas Gerais's State for aggregating an enormous scientific value for the archaeology and paleontology, contend countless archaeological ranches and speleological, with rupestrial and material representations fossil, contributing this way, for the main areas of scientific research accomplished in the area.
\end{abstract}

Besides the notorious archaeological and paleontological importance, Peruaçu's Caves National Park is, as well, an area that reserve with a lot of physical natural and biotic elements wealth that, associates to the current characteristics of the use and occupation standards of the soil, they configure as units of landscape according to the perspective geosystemic framed by BERTRAND (1971) for the scale of local analysis.

With base in the identification and delimitation of these units of landscape, the proposal of this work was to register the temperature data and relative humidity of the air in each one of these units to allow the montage of a database relation where was possible to associate the climatic variation of these attributes to the variation physiognomic of each one of the boarded environments.

Considering the variation of the temperature and relative humidity of the air in ace units landscape relation, it was possible to define the local climatic units of the Peruaçu's Caves National Park, pointing the limits values between each one of them.

\title{
KEY WORDS
}

Peruaçu, Climatology, Local climate, Landscape, Geosystem. 


\section{OS MEUS AGRADECIMENTOS}

Como já é sabido por aqueles que trilharam o mesmo caminho de dedicação a um trabalho de pesquisa de pós-graduação, é fundamental a participação e colaboração conjugada de um grande número de pessoas que, por um motivo ou outro, acabam sendo envolvidas e formando um verdadeiro exército.

Normalmente, na maioria dos agradecimentos redigidos nas teses que tive a oportunidade de ler, percebi que o autor elenca os colaboradores mais próximos e mais ativos em suas pesquisas, finalizando o parágrafo de forma generalizada para agradecer os demais.

Ora! No meu caso, tantas páginas foram escritas em virtude da ajuda de cada um dos envolvidos que resolvi dedicar o espaço que fosse necessário para agradecer nominalmente cada um dos colaboradores, correndo o risco de esquecer-me de alguém ou mesmo fazendo deste um espaço cansativo e sem importância para os demais leitores, mas acreditando que terei manifestado meu agradecimento à altura.

Depois da minha família para a qual reservei a dedicatória, a pessoa de maior influência na escolha da área de estudo, chama-se Cecília Alarsa que, além da amizade de tantos anos, apresentou-me o Parque Nacional Cavernas do Peruaçu... confiando-me, inclusive, a grande aventura de participar da elaboração do seu Plano de Manejo. A você Ciça, meu especial obrigado!

Dentre tantos obrigados especiais que tenho a fazer, quero dirigir um deles para meu orientador, o professor Doutor José Bueno Conti que, sábia e pacientemente, atendeu-me prontamente com o objetivo de amenizar questões que antes das conversas na sua sala, me pareciam obstáculos intransponíveis. Obrigado professor Conti!

Outro professor que gostaria de agradecer chama-se Emerson Galvani pela oportunidade que me deu de participar das disciplinas de climatologia por ele ministradas, onde tentei absorver o máximo de informação e experiência possível. Muito melhor que isso, acredito ter feito um amigo. Valeu Emerson! Incluo entre estes, o Prof. Dr. Felisberto Cavalheiro que hoje se mantém vivo na minha memória pela lição de vida que, despretensiosamente, dava àqueles que o cercavam. Felis! Vendo-nos aí de cima, acredito que pode também sentir a emoção do meu agradecimento. 
Entre tantos que o cercavam, destaco o Professor Yuri que, honrosamente, assumiu a cadeira antes ocupada pelo Felis e que, como tal, pode me dar grande e valiosa contribuição. Obrigado Professor Yuri.

Não poderia deixar de agradecer ao Laboratório de Biogeografia e Climatologia na figura do Rogério, responsável pelo empréstimo de parte dos equipamentos levados a campo. Obrigado Rogério.

Muito longe da Universidade, mais especificamente no próprio Parque Nacional Cavernas do Peruaçu, outro pelotão de pessoas se dispôs a ajudar-me na logística de campo, desde o transporte até a alimentação.

O primeiro desta lista é o Quincas que, munido com boa vontade, profissionalismo e uma possante moto me possibilitou sob condições adversas, chegar a todos os lugares planejados. Além disto, foi ele o responsável em abastecer-me de ótima cachaça produzida em seu alambique e assim poder esquecer a forma geométrica que se encontravam nossos traseiros após quilômetros rodados em estradas de terra e buracos. Obrigado Quincas!

Substituindo o Quincas em alguns momentos, agradeço também o Nilsinho, sem o qual não teria praticado as diferentes formas de se cair de uma motocicleta na lama e na chuva, felizmente sem comprometer os trabalhos de campo.

Outro cara que devo parte do sucesso dos trabalhos de campo chama-se Isaías. Grande Isaías que, com seu caso de amor (uma caminhonete) ajudoume levar toda a tranqueira mais pesada para lá e para cá, oportunidade que demos muitas risadas e firmamos uma grande amizade. Valeu Isaías!

Alem destes, agradeço também Seu Norinho, Dona Anita e seu filho Lú que me receberam com o carinho de uma família, principalmente em momentos que a saudade dos filhos e esposa era maior. Obrigado, obrigado e obrigado por aqueles momentos.

Agradeço também a equipe do IBAMA local (Emerk, Evandro, Flávio, Leonardo, Hélio, Peixe e Zé Santana) que através de conversas informais, me permitiram conhecer melhor o universo ambiental e social em que estava vivenciando. Obrigado a todos vocês! Aproveito aqui para pedir que me 
desculpem por alguma "questão" que ainda tenha ficado pendente, esperando poder contar com vocês posteriormente.

Quero manifestar meus agradecimentos também ao Senhor João Barbosa Oliveira (Gerente do Parque Estadual Veredas do Peruaçu) e toda sua equipe pela recepção e boa conversa. Obrigado Sr. João!

Como uma andorinha só não faz verão, agradeço a colaboração dada pela equipe de consultores do Plano de Manejo do Parque Nacional Cavernas do Peruaçu que, durante os trabalhos de campo, reuniões e seminários me ofereceram enorme contribuição.

Além deste pelotão de colaboradores e amigos que colecionei durante todo esse tempo, agradeço também as empresas que, de uma forma ou de outra, deram sua contribuição para o desenvolvimento deste projeto. São elas:

- CNPq;

- Geoclock

- Instituto Navegar

- PA Brasil - Consultoria e Planejamento Ambiental Ltda.

- Carambi Indústria de Alimentos Ltda.

A TODOS VOCÊS,..MEU MUITÍSSIMO OBRIGADO. 


\section{SIGLAS UTILIZADAS}

ANT - Ambiente Antropizado

APA - Área de Proteção Ambiental

APP - Área de Preservação Permanente

ART - Artigo

C - Conceição (do Mato Dentro, município de)

$\mathrm{CACH}$. Cachoeira (do Itapemirim, município de)

CEL - Coronel (Pacheco)

CONAMA - Conselho Nacional do Meio Ambiente

CONC - Conceição (do Mato Dentro, município de)

FFL - Formação Florestal

FSA - Formação Savânica

FSA - Formação Savânica Estépica

GDSF - Geossistema da Depressão do Rio São Francisco

GfAA - Geofácie do Ambiente Antropogênico

GfFF - Geofácie da Formação Florestal

GfFS - Geofácie da Formação Savânica

GfSE - Geofácie da Formação Savânica Estépica

GOV - Governador (Valadares, município de)

GPSF - Geossistema do Planalto do Rio São Francisco

GSMC - Geossistema da Serras da Mãe Joana e do Cardoso de Minas

IBAMA - Instituto Brasileiro do Meio Ambiente e dos Recursos Naturais Renováveis

INPE - Instituto Nacional de Pesquisas Espaciais

OMM - Organização Mundial de Meteorologia

PARNA - Parque Nacional

PE - Parque Estadual

PNCP - Parque Nacional Cavernas do Peruaçu

PRECIP - Precipitação

SNUC - Sistema Nacional de Unidades de Conservação

TEMP - Temperatura do ar

UC - Unidade de Conservação

UNESCO - Organização das Nações Unidas para Educação, Ciência e Cultura

UR - Umidade relativa do ar

VIT - Vitória (da Conquista, município de)

ZCAS - Zona de Convergência do Atlântico Sul 


\section{ÍNDICE GERAL}

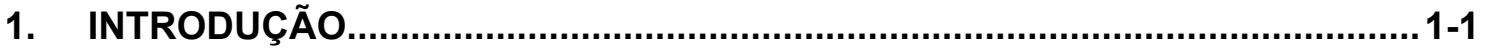

2. O OBJETIVO

3. A METODOLOGIA

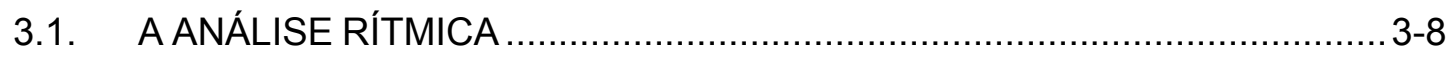

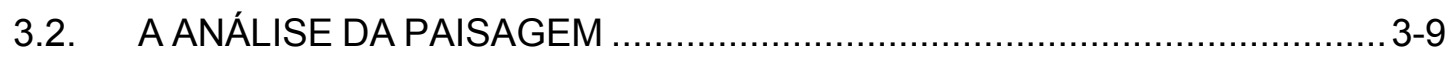

4. A TÉCNICA E OS INSTRUMENTOS UTILIZADOS ..................................... 4-13

4.1. AS FONTES CONSULTADAS PARA A ESCALA REGIONAL ...................4-14

4.2. AS FONTES CONSULTADAS PARA A ESCALA LOCAL ........................4-16

4.3. OS TRABALHOS DE CAMPO ………............................................. $4-17$

4.4. AS TÉCNICAS ADOTADAS E A APRESENTAÇÃO DOS DADOS ............4-21

5. AS CARACTERÍSTICAS GERAIS DA REGIÃO DE ESTUDO …....................5-23

5.1. ASPECTOS SOBRE GEOLOGIA E GEOMORFOLOGIA …...................... 5-31

5.2. ASPECTOS SOBRE A COBERTURA VEGETAL ……........................5-38

5.3. ASPECTOS SOBRE O USO E OCUPAÇÃO DO SOLO ……..................5-47

6. AS UNIDADES DE PAISAGEM DA ÁREA DE ESTUDO..............................6-51

7. O CLIMA DE MINAS GERAIS …………………....................................

8. A CARACTERIZAÇÃO CLIMÁTICA DA REGIÃO DE ESTUDO …................... 8-61

8.1. A CIRCULAÇÃO REGIONAL DA ATMOSFERA …................................. $8-62$

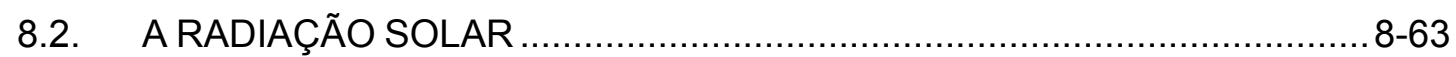

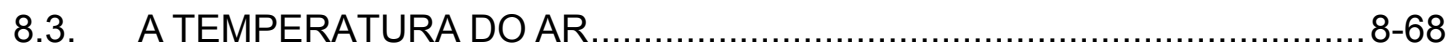

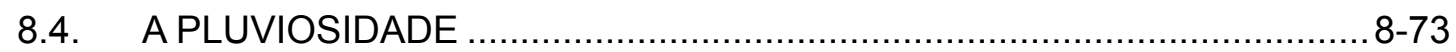

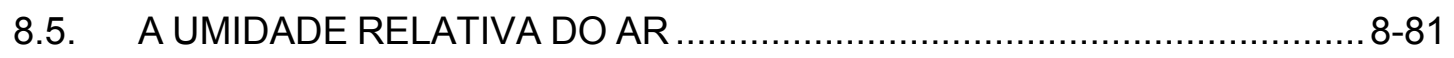

9. A CARACTERIZAÇÃO CLIMÁTICA LOCAL SAZONAL ...............................9-86

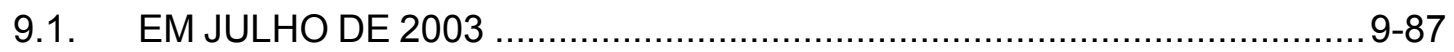

9.1.1. A CIRCULAÇÃO ATMOSFÉRICA E TIPOS DE TEMPO ASSOCIADOS

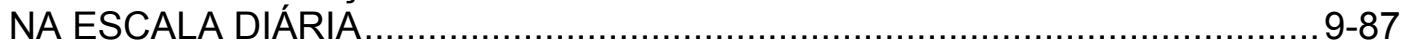

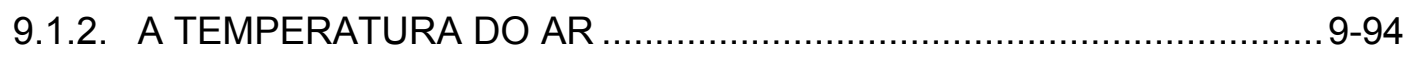

9.1.3. A UMIDADE RELATIVA DO AR ................................................ $9-106$

9.2. EM JANEIRO DE 2004 ……................................................... $9-116$

9.2.1. A CIRCULAÇÃO ATMOSFÉRICA E TIPOS DE TEMPO ASSOCIADOS

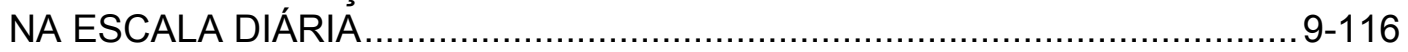

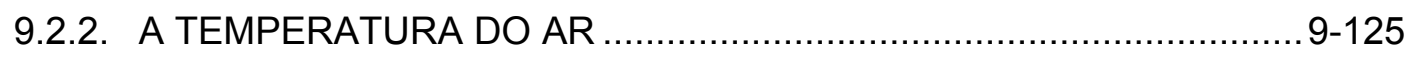

9.2.3. A UMIDADE RELATIVA DO AR .................................................. $9-134$

10. OS RESULTADOS OBTIDOS..........................................................10-143

11. AS CONSIDERAÇÕES FINAIS …………..................................11-148

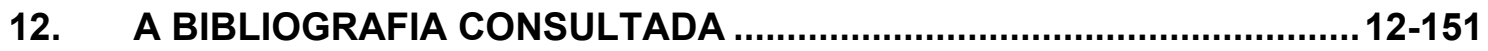

ANEXOS 


\section{RELAÇÃO DE ANEXOS}

ANEXO A: ESTAÇÕES METEOROLÓGICAS DO INMET DE MINAS GERAIS.

ANEXO B: ESTAÇÕES METEOROLÓGICAS DOS ESTADOS DA BAHIA, ESPÍRITO SANTO, RIO DE JANEIRO, SÃO PAULO, MATO GROSSO DO SUL, GOIÁS E DISTRITO FEDERAL E MAIS PRÓXIMAS À MINAS GERAIS.

ANEXO D: AUTORIZAÇÃO DO IBAMA PARA REALIZAÇÃO DE TRABALHO DE CAMPO EM JANEIRO DE 2004 (CÓPIA DIGITALIZADA).

ANEXO E: DECRETO DE CRIAÇÃO DA APA CAVERNAS DO PERUAÇU.

ANEXO F: DECRETO DE CRIAÇÃO DO PE VEREDAS DO PERUAÇU.

ANEXO G: DECRETO DE CRIAÇÃO DO PARNA CAVERNAS DO PERUAÇU.

ANEXO H: RADIAÇÃO SOLAR MÉDIA MENSAL (M/JM²) DE MINAS GERAIS (1961 1990).

ANEXO I: TEMPERATURA DO AR MÉDIA $\left({ }^{\circ} \mathrm{C}\right)$ MENSAL DE MINAS GERAIS (1961 1990).

ANEXO J: PLUVIOSIDADE ACUMULADA (MM) DE MINAS GERAIS (1961 - 1990).

ANEXO K: UMIDADE RELATIVA DO AR (\%) DE MINAS GERAIS (1961 - 1990).

ANEXO L: LOCALIZAÇÃO DOS PONTOS DE AMOSTRAGEM E ASPECTOS GERAIS DO PARQUE NACIONAL CAVERNAS DO PERUAÇU.

ANEXO M: UNIDADES DE PAISAGEM (GEOSSISTEMAS E GEOFÁCIES) DOS PONTOS DE AMOSTRAGEM DO PARQUE NACIONAL CAVERNAS DO PERUAÇU.

ANEXO N: VALORES MÉDIOS DIÁRIOS DE PRESSÃO ATMOSFÉRICA, NEBULOSIDADE, PLUVIOSIDADE, TEMPERATURA E UMIDADE RELATIVA DO AR, REGISTRADOS EM JULHO DE 2003.

ANEXO O: VALORES MÉDIOS DIÁRIOS DE PRESSÃO ATMOSFÉRICA, NEBULOSIDADE, PLUVIOSIDADE, TEMPERATURA E UMIDADE RELATIVA DO AR, REGISTRADOS EM JANEIRO DE 2004. 


\section{ÍNDICE DOS GRÁFICOS}

GRÁFICO 01: DISTRIBUIÇÃO MENSAL DAS TEMPERATURAS MÉDIAS TOTAIS REGISTRADAS NO ESTADO DE MINAS GERAIS.

GRÁFICO 02: VOLUME DE CHUVA ACUMULADO NAS ESTAÇÕES METEOROLÓGICAS DO INMET ENTRE 1961 E 1990.

GRÁFICO 03: VolUmE DE CHUVA ACUMULAdO MENSALMENTE NO ESTADO DE MinAS GERAIS ENTRE 1961 E 1990.

GRÁFICO 04: IDENTIFICAÇÃO DO PERÍODO SECO E ÚMIDO NO ESTADO DE MINAS GERAIS, SEGUNDO A EXPRESSÃO MATEMÁTICA "P $\leq 2$ T" EM CADA ESTAÇÃO METEOROLÓGICA DO INMET DE MINAS GERAIS.

GRÁFICO 05: VARIAÇÃO DIÁRIA MÉDIA DA PRESSÃO BAROMÉTRICA REGISTRADA NO MÊS DE JULHO NO PARQUE NACIONAL CAVERNAS DO PERUAÇU.

GRÁFICO 06: VARIAÇÃO DIÁRIA MÉDIA DA NEBULOSIDADE REGISTRADA NO MÊS DE JULHO no PaRque nacional CaVernas do PeRuaçu.

GRÁFICO 07: VARIAÇÃO DIÁRIA MÉDIA DA TEMPERATURA DO AR REGISTRADA NO MÊS DE JULHO No PARQUe Nacional CAVERnAS do PERUAÇU. 9-93

GRÁFICO 08: VARIAÇÃO DIÁRIA MÉDIA DA UMIDADE RELATIVA DO AR REGISTRADA NO MÊS de JULHo no Parque Nacional CaVernas do PERUaçu. 9-94

GRÁFICO 09: DISTRIBUIÇÃO DE FREQÜÊNCIA (\%) DA TEMPERATURA ( $\left.{ }^{\circ} \mathrm{C}\right)$ REGISTRADA NO Parque nacional CaVernas do Peruaçu (Julho de 2003). 9-96

GRÁFICO 10: DISTRIBUIÇÃO DE FREQÜÊNCIA (\%) DA TEMPERATURA MÉDIA ( $\left.{ }^{\circ} \mathrm{C}\right)$ DOS pontos de amostragem no Parque nacional CaVernas do Peruaçu (Julho de 2003). 9-96

GRÁFICO 11: TEMPERATURA MÉdIA ( ${ }^{\circ} \mathrm{C}$ ) DOS PONTOS DE AMOSTRAGEM DISTRIBUÍDA Segundo as cotas altimétricas do Parque nacional Cavernas do Peruaçu (JULHO DE 2003). 9-97

GRÁFICO 12: DISTRIBUIÇÃO DE FREQÜÊNCIA (\%) DA TEMPERATURA MÉDIA $\left({ }^{\circ} \mathrm{C}\right)$ DOS PONTOS DE AMOSTRAGEM SEGUNDO OS COMPARTIMENTOS GEOMORFOLÓGICOS DO PaRque nacional CaVernas do Peruaçu (Julho de 2003). 9-100

GRÁFICO 13: TEMPERATURA MÉDIA $\left({ }^{\circ} \mathrm{C}\right)$ REGISTRADA NAS UNIDADES DE PAISAGEM DAS geofácies do Parque Nacional CaVernas do Peruaçu (JULHo de 2003).... 9-101 GRÁFICO 14: TEMPERATURA MÉDIA $\left({ }^{\circ} \mathrm{C}\right)$ DOS GEOSSISTEMAS DO PARQUE NACIONAL CAVERnas do PERuaçu (JuLHo de 2003). 9-103

GRÁFICO 15: DISTRIBUIÇÃO DE FREQÜÊNCIA (\%) DA UMIDADE RELATIVA DO AR (\%) REgistrada no PARQue Nacional CAVERnas do PERUaçu (JULHo de 2003).. 9-107 
GRÁFICO 16: DISTRIBUIÇÃO DE FREQÜÊNCIA (\%) DA UMIDADE RELATIVA DO AR MÉDIA (\%) dos pontos de amostragem no Parque nacional Cavernas do Peruaçu (JULHO DE 2003). 9-108

GRÁFICO 17: UMIDADE RELATIVA DO AR MÉDIA (\%) DOS PONTOS DE AMOSTRAGEM DISTRIBUÍDA SEGUNDO AS COTAS ALTIMÉTRICAS DO PARQUE NACIONAL CAVERNAS DO PERUAÇU (JULHO dE 2003). $9-108$

GRÁFICO 18: DISTRIBUIÇÃO DE FREQÜÊNCIA (\%) DA UMIDADE RELATIVA MÉDIA DO AR (\%) DOS PONTOS DE AMOSTRAGEM SEGUNDO OS COMPARTIMENTOS GEOMORFOLÓGICOS do Parque nacional CaVernas do Peruaçu (JuLho de 2003). 9-111

GRÁFICO 19: UMIDADE RELATIVA MÉDIA DO AR (\%) REGISTRADA NAS UNIDADES DE paisagem das geofácies do Parque nacional CaVernas do Peruaçu (JUlHo de 2003).

GRÁFICO 20: UMIDADE RELATIVA MÉDIA DO AR (\%) DOS GEOSSISTEMAS DO PARQUE Nacional CaVernas do Peruaçu (JULHo de 2003). 9-113

GRÁFICO 21: VARIAÇÃO DIÁRIA MÉDIA DA PRESSÃO BAROMÉTRICA REGISTRADA NO MÊS DE JANEIRO DE 2004 No PARQUe Nacional CAVERnAS do PERUaÇu. $9-122$ GRÁFICO 22: VARIAÇÃO DIÁRIA MÉDIA DA NEBULOSIDADE REGISTRADA NO MÊS DE JANEIRO DE 2004 NO PARQUE NACIONAL CAVERNAS DO PERUAÇU. 9-122

GRÁFICO 23: VARIAÇÃO DIÁRIA MÉDIA DA TEMPERATURA DO AR REGISTRADA NO MÊS DE JANEIRO DE 2004 NO PARQUE NACIONAL CAVERNAS DO PERUAÇU. 9-123

GRÁFICO 24: VARIAÇÃO DIÁRIA MÉDIA DA UMIDADE RELATIVA DO AR REGISTRADA NO MÊS DE JANEIRO DE 2004 No PARQUE NaCIONAL CAVERnAS do PERUaÇu. $9-123$

GRÁFICO 24: VARIAÇÃO DIÁRIA DA PLUVIOSIDADE ACUMULADA REGISTRADA NO MÊS DE janeiro de 2004 no Parque nacional Cavernas do Peruaçu, associada aOS EPISÓDIOS DE ZCAS.

GRÁFICO 26: DISTRIBUIÇÃO DE FREQÜÊNCIA (\%) DA TEMPERATURA $\left({ }^{\circ} \mathrm{C}\right)$ REGISTRADA NO PaRque Nacional CaVernas do Peruaçu (JANeiRo de 2004). 9-126

GRÁFICO 27: DISTRIBUIÇÃO DE FREQÜÊNCIA (\%) DA TEMPERATURA MÉDIA $\left({ }^{\circ} \mathrm{C}\right)$ DOS pontos de amostragem no Parque nacional CaVernas do Peruaçu (Janeiro DE 2004)

GRÁFICO 28: TEMPERATURA MÉDIA $\left({ }^{\circ} \mathrm{C}\right)$ DOS PONTOS DE AMOSTRAGEM DISTRIBUÍDA SEgundo as cotas altimÉtricas do PaRque nacional CaVernas do PeruaÇu (JANEIRO DE 2004). $9-128$

GRÁFICO 29: DISTRIBUIÇÃO DE FREQÜÊNCIA (\%) DA TEMPERATURA MÉDIA $\left({ }^{\circ} \mathrm{C}\right)$ DOS PONTOS DE AMOSTRAGEM SEGUNDO OS COMPARTIMENTOS GEOMORFOLÓGICOS DO Parque nacional Cavernas do Peruaçu (Janeiro de 2004). 9-130 
GRÁFICO 30: TEMPERATURA MÉDIA ( $\left.{ }^{\circ} \mathrm{C}\right)$ REGISTRADA NAS UNIDADES DE PAISAGEM DAS

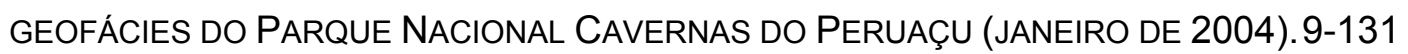
GRÁFICO 31: TEMPERATURA MÉdIA $\left({ }^{\circ} \mathrm{C}\right)$ DOS GEOSSISTEMAS DO PARQUE NACIONAL CAVERNAS DO PERUAÇU (JANEIRO DE 2004). 9-132

GRÁFICO 32: DISTRIBUIÇÃO DE FREQÜÊNCIA (\%) DA UMIDADE RELATIVA MÉDIA (\%) DOS pontos de amostragem no Parque nacional Cavernas do Peruaçu (Janeiro DE 2004). 9-135

GRÁFICO 33: UMIDADE RELATIVA MÉDIA (\%) DOS PONTOS DE AMOSTRAGEM DISTRIBUÍDA Segundo as cotas altimétricas do Parque nacional Cavernas do Peruaçu (JANEIRO DE 2004). $9-135$

GRÁFICO 34: DISTRIBUIÇÃO DE FREQÜÊNCIA (\%) DA UMIDADE RELATIVA MÉDIA (\%) DOS PONTOS DE AMOSTRAGEM SEGUNDO OS COMPARTIMENTOS GEOMORFOLÓGICOS DO PARQue Nacional CAVERnas do PERUaÇu (JANEIRO dE 2004). 9-137

GRÁFICO 35: UMIDADE RELATIVA MÉDIA (\%) REGISTRADA NAS UNIDADES DE PAISAGEM DAS GEOFÁCIES (JANEIRO DE 2004). 9-139

GRÁFICO 36: UMIDADE RELATIVA MÉDIA (\%) DOS GEOSSISTEMAS DO PARQUE NACIONAL CAVERNAS DO PERUAÇU (JANEIRO DE 2004). $9-140$ 


\section{ÍNDICE DAS FIGURAS}

FIGURA 01: ESTRUTURA HIERÁRQUICA DAS UNIDADES DE PAISAGEM ADOTADAS NESTE TRABALHO (APENAS OS NÍVEIS IV, V E VI).

FIGURA 02: MAPA DE LOCALIZAÇÃO DAS ESTAÇÕES METEOROLÓGICAS DO INMET

UTILIZADAS NESTE ESTUDO.

FIGURA 03: PONTOS VISITADOS (PONTOS DE AMOSTRAGEM) NO PARQUE NACIONAL CAVERnAS do PERUAÇU. 4-18

FIGURA 04: INSTRUMENTOS UTILIZADOS PARA REGISTRO DE DADOS ENTRE OS DIAS $01 \mathrm{~A}$ 30 DE JULHO DE 2003 E 05 A 27 DE JANEIRO DE 2004 NO PARQUE NACIONAL CAVERnas do PERUAÇu.

FIGURA 05: Localização do Parque Nacional CaVernas do Peruaçu. $5-24$

FIGURA 06: TIPO DE REPRESENTAÇÃO RUPESTRE ENCONTRADA NO PARQUE NACIONAL

CAVERNAS Do PERUAÇU. $5-25$

FIGURA 07: VEREDA EXISTENTE AO LONGO DO ALTO CURSO DO RIO PERUAÇU. $5-27$ figura 08: LocalizaÇão da Área de Proteção Ambiental CaVernas do Peruaçu,

Parque Estadual Veredas do Peruaçu e Parque nacional Cavernas do PERUAÇU.

FIGURA 09: TRECHO DO COMPARTIMENTO GEOMORFOLÓGICO DA DEPRESSÃO DO SÃO FRANCISCO. 5-33

FIGURA 10: TRECHO DO COMPARTIMENTO CARSTIFICADO. 5-34

FIGURA 11: TRECHO DA ZONA DE TRANSIÇÃO. ........................................................ $5-35$

FIGURA 12: TRECHO DO COMPARTIMENTO DO PLANALTO DOS GERAIS. 5-36

FIGURA 13: COMPARTIMENTOS GEOMORFOLÓGICOS DO PARQUE NACIONAL CAVERNAS DO PERUAÇU.

FIGURA 14: FORMAÇÕES VEGETAIS DEFINIDAS PELO IBGE (2004) NA ESCALA 1:5.000.000 PRESENTES No PARQUE NACIONAL CAVERNAS do PERUAÇU.

FIGURA 15: FORMAÇÕES VEGETAIS PREDOMINANTES NO PARQUE NACIONAL CAVERNAS

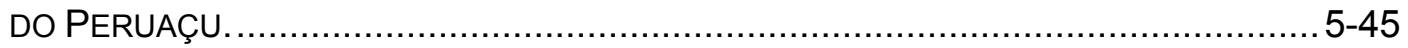

FIGURA 16: TRECHO DA ÁREA DE ESTUDO OCUPADA PELA FORMAÇÃO FLORESTAL...... 5-46 FIGURA 17: TRECHO DA ÁREA DE ESTUDO OCUPADA PELA FORMAÇÃO SAVÂNICA........5-46 FIGURA 18: TRECHO DA ÁREA DE ESTUdO OCUPADA PELA FORMAÇÃO SAVÂNICA ESTÉPICA. $5-47$

FIGURA 19: ÁREA DEGRADADA PRESENTE NO AMBIENTE DA FORMAÇÃO FLORESTAL. .. 5-50 FIGURA 20: DELIMITAÇÃo dOS GeOSSISTEMAS NO PARQUe NACIONAL CAVERNAS dO PERUAÇU. $6-53$ 
FIGURA 21: VISTA GERAL DAS UNIDADES GEOSSISTÊMICAS IDENTIFICADAS NO PARQUE Nacional Cavernas do Peruaçu. $6-54$

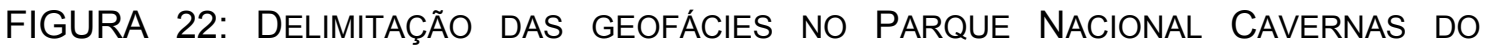

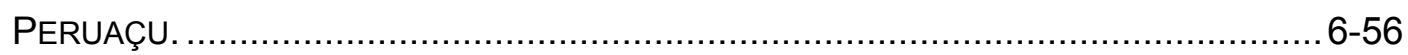

FIGURA 23: OS CLIMAS ZONAIS DO BRASIL. ................................................... $7-59$

FIGURA 24: ClimAS REgIONAIS DO ESTAdO DE MINAS GERAIS, SEGUNDO O IBGE (2005), COM DESTAQUe PARA O PARQUE NACIONAL CAVERNAS do PERUAÇU................... 7-60

FIGURA 25: RADIAÇÃO SOLAR (MJ/M²) MÉDIA ESTIMADA PARA O TOPO DA ATMOSFERA NO MÊS DE JULHO NO ESTADO DE MINAS GERAIS. $8-66$

FIGURA 26: RADIAÇÃO SOLAR (MJ/M²) MÉDIA ESTIMADA PARA O TOPO DA ATMOSFERA NO MÊS DE JANEIRO NO ESTADO DE MINAS GERAIS. 8-67

FIGURA 27: Temperatura MÉdia $\left({ }^{\circ} \mathrm{C}\right)$ NO Estado de MinAs GeRAIS, ENTRE $1961 \mathrm{E}$ 1990.

FIGURA 28: TeMPERATURA MÉdiA $\left({ }^{\circ} \mathrm{C}\right)$ NO Estado de MinAs GeRAIS, DOS MESES DE DEZEMBRO, JANEIRO, FEVEREIRO E MARÇO ENTRE 1961 E 1990.

FIGURA 29: Temperatura mÉdia $\left({ }^{\circ} \mathrm{C}\right)$ NO Estado de Minas Gerais, dos meses de JUNHO, JULHO, AGOSTO E SETEMBRO ENTRE 1961 E 1990. 8-73

FIGURA 30: Volume de CHUVA (MM) ACumulado No Estado de Minas GeRAIS ENTRE 1961 E 1990.

FIGURA 31: Volume de CHUVA (MM) ACUMULAdO NO ESTAdO DE MinAs GeRAis, NOS MESES DE DEZEMBRO, JANEIRO, FEVEREIRO E MARÇO ENTRE 1961 E 1990. 8-78

FIGURA 32: VolUme DE CHUVA (MM) ACUMULAdO NO ESTAdO DE MinAs GERAIS, NOS MESES DE JUNHO, JULHO, AGOSTO E SETEMBRO ENTRE 1961 E 1990. 8-79

FIGURA 33: UMIDADE RELATIVA DO AR (\%) MÉDIA NO ESTADO DE MINAS GERAIS DOS MESES DE DEZEMBRO, JANEIRO, FEVEREIRO E MARÇO ENTRE 1961 E 1990. 8-84

FIGURA 34: UMIDADE RELATIVA DO AR (\%) MÉDIA NO ESTADO DE MINAS GERAIS DOS MESES DE JUNHO, JULHO, AGOSTO E SETEMBRO ENTRE 1961 E 1990 8-85

FIGURA 35: PASSAGEM dE UMA FRENTE FRIA SOBRE O OCEANO NA ALTURA DA REGIÃO SUL DO BRASIL (INDICADA PELAS SETAS PRETAS), REGISTRANDO O DESVIO (INDICADO PELA SETA VERMELHA) DE UMA FAIXA DE INSTABILIDADE SOBRE O INTERIOR NORTE DE Minas GeRAis (MOlduRA AZUL), ONDE ESTÁ localizado O PARQUE NACIONAL CAVERnAS Do PERUAÇU. 9-88

FIGURA 36: REGISTRO DA PASSAGEM DA TERCEIRA FRENTE FRIA SOBRE O TERRITÓRIO MINEIRO, PRÓXIMO Á PATOS DE MINAS NO DIA 11 DE JULHO DE 2003, QUANDO FOI OBSERVADO UM LIGEIRO AUMENTO DA NEBULOSIDADE NO PARQUE NACIONAL CaVernas do Peruaçu. 9-90 
Figura 37: Temperatura média $\left({ }^{\circ} \mathrm{C}\right)$ No Parque nacional CaVernas do Peruaçu NO MÊS DE JULHO DE 2003.

FIGURA 38: UMIDADE RELATIVA MÉDIA DO AR (\%) DO PARQUE NACIONAL CAVERNAS DO PERUAÇU NO MÊS DE JULHO DE 2003

FIGURA 39: REGISTRO DA PASSAGEM DA TERCEIRA FRENTE FRIA SOBRE O TERRITÓRIO MINEIRO, PRÓXIMO A PATOS DE MINAS E PIRAPORA (INDICADA PELAS SETAS VERMELHAS) ENTRE OS DIAS 2 E 3 DE JANEIRO DE 2004. 9-116

FIGURA 40: CAMPOS DE TEMPERATURA DE BRILHO MÉDIO, OBTIDOS ATRAVÉS DO SATÉLITE GOES 08, MOSTRANDO A PRESENÇA DA ZCAS NO PERÍODO DE 02 A 06 DE JANEIRO DE 2004, COM DESTAQUE NA REGIÃO DE ESTUDO (MOLDURA VERMELHA). 9-117

FIGURA 41: CAMPOS DE TEMPERATURA DE BRILHO MÉDIO, OBTIDOS ATRAVÉS DO SATÉLITE GOES 08, MOSTRANDO A PRESENÇA DA ZCAS NO PERÍODO DE 10 A 20 DE JANEIRO DE 2004, COM DESTAQUE NA REGIÃO DE ESTUDO (MOLDURA VERMELHA).

FIGURA 42: CAMPOS DE TEMPERATURA DE BRILHO MÉDIO, OBTIDOS ATRAVÉS DO SATÉLITE GOES 08, MOSTRANDO A PRESENÇA DA ZCAS NO PERÍODO DE 25 A 29 DE JANEIRO DE 2004, COM DESTAQUE NA REGIÃO DE ESTUdO (MOLDURA VERMELHA). $9-121$

Figura 43: Temperatura média $\left({ }^{\circ} \mathrm{C}\right)$ do Parque nacional CaVernas do Peruaçu NO MÊS DE JANEIRO DE 2004

FIGURA 44: FISIONOMIA XEROMÓRFICA ENCONTRADA NO COMPARTIMENTO GEOMORFOLÓGICO CARSTIFICADO.

FIGURA 45: UMIDADE RELATIVA dO AR MÉdIA (\%) DO PARQUE NACIONAL CAVERNAS DO PERUAÇU NO MÊS DE JANEIRO DE 2004.

FIGURA 46: UNIDADES CLIMÁtICAS LOCAIS DO PARQUE NACIONAL CAVERNAS DO PERUAÇU. 10-147 


\section{ÍNDICE DOS QUADROS}

QUADRO 01: RELAÇÃO DE INSTRUMENTOS UTILIZADOS NA COLETA DE DADOS PRIMÁRIOS.

QUADRO 02: ENQUADRAMENTO DOS AGRUPAMENTOS VEGETAIS SEGUNDO SUAS RESPECTIVAS FORMAÇÕES. ................................................................... $5-44$

QUADRO 03: TAXONOMIA ESTABELECIDA PARA AS UNIDADES DE PAISAGEM DEFINIDAS COMO GEOFÁCIES. 
DELIMITAÇÃO DE UNIDADES CLIMÁTICAS LOCAIS NO PARQUE NACIONAL CAVERNAS DO PERUAÇU (VERSÃO REVISADA) 
A escolha do Parque Nacional Cavernas do Peruaçu para realização de uma pesquisa climatológica foi determinada pela incipiência de trabalhos mais detalhados sobre o assunto, quando foi identificada a necessidade de um estudo mais detalhado vinculado a uma perspectiva de preservação dos sítios arqueológicos ali existentes que são, indubitavelmente, o principal atrativo científico para arqueólogos e paleontólogos, além de pesquisas voltadas para a geologia e biologia.

Dessa predileção pelas pesquisas voltadas para a arqueologia, paleontologia, geologia e biologia, foi mantida uma deficiência de conhecimento da dinâmica climática ocorrente nos diferentes ambientes fisiográficos contidos no Parque Nacional Cavernas do Peruaçu, onde são encontradas áreas de vegetação natural representas por diferentes formações e ambientes antropogênicos, suscitando o conhecimento da variação climática de cada um deles.

Tal deficiência foi constatada na etapa de levantamento bibliográfico, quando foi notado um acervo de estudos climatológicos pouco significativos na área de estudo e que, geralmente, são incluídos em trabalhos pesquisa de forma sucinta sem relação relevante entre os objetos pesquisados e os aspectos climáticos, propriamente dito, restringidos às classificações genéricas válidas para escalas de análise menores como, por exemplo, são as classificações de Köppen e Gaussen, pouco significativos para a compreensão climática mais detalhada de uma área como é o Parque Nacional Cavernas do Peruaçu.

Por isso, aquela perspectiva inicial de pesquisa vinculada exclusivamente à preservação de sítios arqueológicos foi suplantada em face de uma análise mais abrangente que contemplasse todo Parque Nacional Cavernas do Peruaçu, convergindo para as questões de qualidade ambiental de toda aquela Unidade de Conservação em face das características fisionômicas ali encontradas.

Com os resultados obtidos acredito estar contribuindo para ampliar o conhecimento do Parque Nacional Cavernas do Peruaçu que se mostrou como um rico campo de estudos para as ciências da Terra, haja vista, muita coisa ainda estar por ser descoberta.

Em linhas gerais, além desta introdução, este trabalho está estruturado em mais onze capítulos que pretendem expor de forma clara todo o processo 
investigatório percorrido até a proposição das unidades climáticas locais que foram estabelecidas com base na proposta e no levantamento da hipótese apresentada no segundo capítulo.

No terceiro capítulo são apresentados sucintamente os métodos científicos adotados para a análise climática e para a delimitação das unidades de paisagens, seguido pela apresentação no quarto capítulo das técnicas e instrumentos utilizados na coleta dos dados primários e secundários.

Passando para a descrição da área de estudo, no quinto capítulo são feitas algumas considerações gerais sobre o Parque Nacional Cavernas do Peruaçu na condição de área de estudo, onde são considerados os aspectos físicos, bióticos e antrópicos ali predominantes.

Por sua vez, o sexto capítulo trata especificamente das unidades de paisagens definidas neste trabalho enquadradas na escala dos Geossistemas e Geofácies considerando, sobretudo, as características fisionômicas reveladas na descrição dos aspectos da área de estudo contidos no capítulo anterior.

No sétimo capítulo, são contempladas duas classificações climáticas para o Brasil e Minas Gerais, respectivamente, visando o enquadramento da área de estudo numa determinada zona climática zonal para poder entender as variações climáticas locais na condição de normalidade ou anomalia.

Uma vez que a caracterização climática local deve considerar, também, as características atuantes numa escala mais abrangente (escala regional), o oitavo capítulo pretendeu esboçar sucintamente a dinâmica atmosférica atuante sobre o território brasileiro por ser o principal mecanismo de influência das características climáticas do território brasileiro, produzindo tipos de tempo que determinam o comportamento dos atributos climáticos que se manifestam numa evolução rítmica e de caráter habitual.

Ainda no oitavo capítulo, são descritas as variações da radiação solar, da temperatura, umidade relativa do ar e pluviosidade registradas no período climatológico entre 1961 e 1990, sobre todo o território mineiro, com destaque para a região norte deste estado, onde está localizada a área de estudo.

Ampliando a escala de análise para o nível local, no nono capítulo, são apresentadas as características climáticas de temperatura e umidade relativa 
do ar registradas nos trabalhos de campo no Parque Nacional Cavernas do Peruaçu, durante os meses de julho de 2003 e janeiro de 2004.

Neste capítulo pretendeu-se, também, apresentar uma descrição sucinta da dinâmica atmosférica atuante nestes períodos e a influência dessa dinâmica na variação diária dos valores de pressão barométrica, nebulosidade, temperatura e umidade relativa do ar.

No décimo e penúltimo capítulo, é realizada a análise dos resultados com a apresentação das unidades climáticas na escala local do Parque Nacional Cavernas do Peruaçu, na condição de uma proposta preliminar.

Finalizando esta pesquisa, o décimo primeiro capítulo apresenta algumas considerações finais, onde são ressaltados alguns dos pontos mais importantes do que foi observado ao longo do trabalho, buscando uma correlação com as condições de preservação e degradação da área de estudo segundo as unidades de paisagem definidas. No capítulo seguinte, segue a lista do acervo bibliográfico consultado, além de documentos anexos. 
DELIMITAÇÃO DE UNIDADES CLIMÁTICAS LOCAIS NO PARQUE NACIONAL CAVERNAS DO PERUAÇU (VERSÃO REVISADA)

\section{O OBJETIVO}


No cenário ambiental brasileiro, as Unidades de Conservação têm a importante função de preservação do patrimônio natural, dentro das quais, inúmeras são as linhas de pesquisas desenvolvidas.

Entretanto, em grande parte dos trabalhos publicados sobre Unidades de Conservação nota-se pouca atenção dada aos aspectos climatológicos na condição de um estudo relevante para o entendimento de outros aspectos ali inseridos, relegando-o a uma importância secundária e simplificada às classificações genéricas e de pouca aplicabilidade para os níveis mais próximos à superfície.

Por esse motivo, a proposta desta pesquisa foi a delimitação das unidades climáticas locais no Parque Nacional Cavernas do Peruaçu com base nos dados de temperatura e umidade relativa do ar com o objetivo de entendimento do comportamento climático dos diferentes ambientes ali existentes.

Para sustentar tal proposta, foi lançada a hipótese de que, definidas as unidades de paisagens enquadradas na escala local (geossistemas) seria possível obter dados primários de temperatura e umidade relativa do ar com certo grau de homogeneidade climática que permitisse ser agrupadas na condição unidades climáticas locais no Parque Nacional Cavernas do Peruaçu. 
DELIMITAÇÃO DE UNIDADES CLIMÁTICAS LOCAIS NO PARQUE NACIONAL CAVERNAS DO PERUAÇU (VERSÃO REVISADA)

3. A METODOLOGIA 
A metodologia adotada para este trabalho, foi definida com base nos arcabouços teóricos e conceituais que permeiam a análise rítmica climática de MONTEIRO (1969), possibilitando um enfoque geográfico e de forma dinâmica a partir da seqüência habitual das situações atmosféricas registradas na área de estudo.

Um outro conceito adotado corresponde àquele voltada à diferenciação dos diferentes ambientes fisiográficos ali existentes a partir da teoria geossistêmica emoldurada por BERTRAND (1971) como ponto de partida para a identificação das unidades de paisagem.

\subsection{A ANÁLISE RÍTMICA}

A análise climática rítmica, segundo SORRE (1934), corresponde à idéia de ocorrência de estados atmosféricos sobre um determinado lugar em sua sucessão habitual dos tipos de tempo; afirmando e sendo ratificado por inúmeros outros autores que esse ritmo próprio da sucessão habitual "é um dos elementos essenciais do clima".

Com base no mesmo autor (op. cit., 1934), esses estados atmosféricos caracterizam-se "pelas suas propriedades dinâmicas e estáticas da coluna atmosférica, composição química, pressão, tensão dos gases, temperatura, grau de saturação, comportamento quanto aos raios solares, poeiras e matérias orgânicas em suspensão, estado do campo elétrico, velocidade e deslocamento das moléculas, etc.".

Nesta perspectiva, tanto o conceito de "ritmo", quanto o de "sucessão" demandam a interpretação dos fenômenos climáticos em duas principais escalas de grandeza espacial que são a escala regional e local.

Estas escalas de análise, segundo SORRE (op. cit., 1934) correspondem às seguintes descrições:

O clima regional combina climas locais próximos à superfície, onde estes podem ser identificados por algumas características comuns em virtude de um dinamismo atmosférico predominante, subordinados aos elementos geográficos estáticos, como a esculturação do relevo, a proximidade do oceano; entre outros, que exercem extrema importância na intensidade e ritmo climático. 
O clima local, por sua vez, pode ser descrito como a ação dos controles climáticos combinados com a temperatura, pressão, estado elétrico, circulação atmosférica, entre outros, que determinam os diversos estados de "tempo" sobre uma área e sua sucessão rítmica.

Pelo procedimento metodológico da análise rítmica adotada para este estudo é importante que a escala superior (regional) seja contemplada visando, sobretudo, a compreensão da dinâmica atmosférica atuante sobre a região de estudo.

Neste trabalho, o enquadramento do clima regional corresponde à abrangência do Estado de Minas Gerais onde foram abordados os domínios climáticos, seguidos pela caracterização da circulação atmosférica regional predominante e aquela registrada nos meses de julho de 2003 e janeiro de 2004, além das características dos atributos climáticos de temperatura e umidade relativa do ar.

Para a escala climática local, a área correspondente é o Parque Nacional Cavernas do Peruaçu e seu entorno que totalizam $198.000 \mathrm{~m}^{2}$ de área mapeada enquadrada entre as seguintes coordenadas:

- $\mathrm{X} 1=561.930 .1580$

- $\quad X 2=604.682 .6667$

- $\mathrm{Y} 1=8.308 .594 .8340 ; \mathrm{e}$,

- $\quad \mathrm{Y} 2=8.355 .000 .0000$.

\subsection{A ANÁLISE DA PAISAGEM}

Sobre a paisagem, referenciar-se por ela para uma análise geográfica possibilita conduzir os estudos sobre o espaço como uma categoria de análise dinâmica, onde os elementos físicos, bióticos e antrópicos são ativos e complementares; não obedecendo, necessariamente, os limites demarcados pelo processo de transformação deste espaço em território.

Para CRISTOFOLETTI (1997, p. 10), "a paisagem como campo de investigação da geografia permite que o espaço seja compreendido como um sistema ambiental, físico e socioeconômico, que possui uma estruturação, um 
funcionamento e uma dinâmica dos elementos físicos, biogeográficos, sociais e econômicos".

Não obstante, os limites associados a uma paisagem são estabelecidos pela comunhão dos fatores naturais que a formaram, engendrados pela ação do homem como agente transformador desta paisagem natural, homogeneizandoa.

A paisagem é mais do que aquilo que é observado "in loco"; é um sítio que agrega todo um legado da evolução natural e histórico do ambiente em que se encontra, o qual moldou aquela paisagem; e que ainda recebe e deixa registrar todas as influências dos tempos atuais na condição de um processo (grifo meu) de transformação constante dessa paisagem. Portanto, uma ótima fonte de conhecimento e estudo para a Geografia.

No seu relato sobre a história da filosofia, ARANHA (1996) afirma que a paisagem é um elemento bastante presente já desde o período pré-socrático (Séc. VI a.C.), quando Heráclito, de Éfaso, já afirmava que "a natureza é um perpétuo vir a ser, isto é, um constante movimento de transformação" (P. 108).

Segundo a mesma autora (op. cit. 1996), essa época reflete o momento de passagem do pensamento mítico para o racional, onde o espaço e a natureza passaram por novas abordagens, rejeitando as interferências dos agentes divinos na explicação dos fenômenos, possuindo grande vínculo com as ciências até o século XVII, quando as ciências escolheram seus próprios métodos e separaram-se da filosofia.

Para o presente trabalho, a delimitação e a análise das unidades de paisagem adotadas basearam-se no pensamento moderno no qual o conceito de geossistema foi emoldurado por BERTRAND (1971), a partir do qual é possível realizar uma abordagem sistêmica dos elementos naturais e antrópicos.

Para este autor (op. cit., 1971), a paisagem "não é uma simples adição de elementos geográficos disparatados. É sim, numa determinada porção do espaço, o resultado da combinação dinâmica e, portanto, instável dos elementos físicos, biológicos e antrópicos que, reagindo dialeticamente uns sobre os outros, fazem dela um conjunto único e indissociável em perpétua evolução" (P. 02). 
No seu sistema taxonômico, estabelece seis níveis de classificação espaçotemporal da paisagem que são: (i) Zona; (ii) Domínio; (iii) Região Natural; (iv) Geossistema; (v) Geofácie; e, (vi) Geótopo, como podem ser observados na estrutura hierárquica apresentada na Figura 01, mostrando apenas os níveis iv, v e vi.

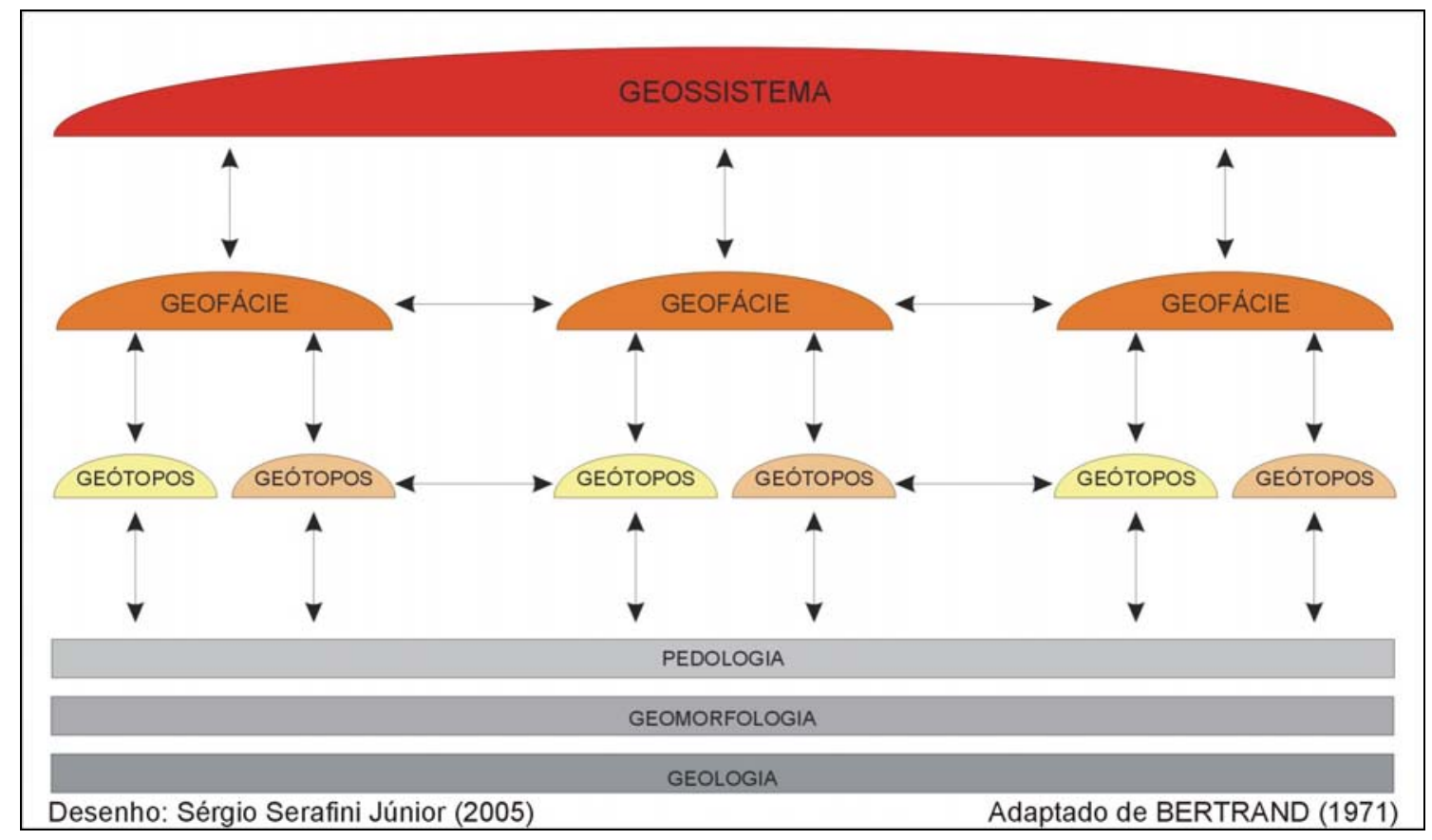

FIGURA 01: Estrutura hierárquica das unidades de paisagem adotadas neste trabalho (apenas os níveis iv, $v$ e vi).

Inserindo a área de estudo neste sistema taxonômico a partir da perspectiva dos objetivos proposto neste trabalho, as unidades de paisagem definidas estão inseridas no âmbito dos geossistemas e geofácies que o autor define da seguinte forma:

Geossistema é uma paisagem nítida e bem circunscrita que pode ser identificada instantaneamente nas fotografias aéreas [...] resultante da combinação local e única de todos os fatores (declividade, clima, rocha, manto de decomposição, hidrologia das vertentes) e de uma dinâmica comum (mesma geomorfogênese, pedogênese idêntica, mesma degradação antrópica da vegetação) [...] caracterizando-se assim, por certa homogeneidade fisionômica, por uma forte unidade ecológica e biológica. 
É uma unidade dimensional compreendida entre alguns quilômetros quadrados e algumas centenas de quilômetros [...] correspondendo a dados ecológicos relativamente estáveis que, correspondem à dinâmica climática ativa nesta escala.

Pode-se admitir que exista na escala considerada uma sorte de 'contínuo' ecológico no interior de um mesmo geossistema, enquanto que a passagem de um geossistema para outro é marcada por uma descontinuidade ecológica.

Geofácie corresponde a um setor fisionomicamente homogêneo, onde se desenvolvem uma mesma fase de evolução geral do geossistema [...]. Representa uma pequena malha na cadeia das paisagens que se sucedem no tempo e no espaço no interior de um mesmo geossistema [...]. Estas unidades fisionômicas se unem então numa mesma família geográfica que são os geofácies. (BERTRAND, G., 1971 - pág. 11 a 16). 
DELIMITAÇÃO DE UNIDADES CLIMÁTICAS LOCAIS NO PARQUE NACIONAL CAVERNAS DO PERUAÇU

\section{A TÉCNICA E OS INSTRUMENTOS \\ UTILIZADOS}


Durante a elaboração deste trabalho muitas foram as fontes utilizadas para obter as informações necessárias, indo desde a pesquisa bibliográfica para conhecimento dos estudos já realizados na área por outros pesquisadores até a ida ao campo para coleta de dados climáticos.

Em vista disso, o procedimento de coleta das informações apresentadas foi estruturado segundo as escalas de análise aqui abordadas (regional e local), como segue.

\subsection{AS FONTES CONSULTADAS PARA A ESCALA REGIONAL}

A caracterização climática regional aqui apresentada baseou-se, notoriamente, em dados bibliográficos reunidos de diferentes fontes.

Do Instituto Nacional de Meteorologia (INMET, 1992) foram obtidas as normais climatológicas registradas numa série histórica de 30 anos (1961 a 1990) que, na data de publicação destes dados, dispunha de uma rede de 32 estações meteorológicas instaladas no Estado de Minas Gerais.

Entretanto, cabe observar que dentre as 32 estações, 22 delas estavam concentradas na porção centro-sul de Minas Gerais, deixando extensas áreas descobertas de registros na porção centro-norte, como mostra a Figura 02.

Posteriormente ao encerramento do $2^{\mathrm{a}}$ período normal climatológico definido pela Organização Mundial de Meteorologia (1961 a 1990), nessa porção norte já foram instaladas 35 novas estações meteorológicas, algumas delas desde a década de 80 . No entanto, devido ao elevado custo destes dados não foi possível considera-los na análise regional deste trabalho, que será apresentado mais adiante.

Além das estações localizadas nesse Estado, foram consideradas, também, outras que se localizam nos Estados vizinhos (Bahia, Espírito Santo, Rio de Janeiro, São Paulo, Mato Grosso do Sul, Goiás e Distrito Federal), mais especificamente, aquelas localizadas próximas das divisas interestaduais, por compreendê-las importantes para a identificação da continuidade da variação climática no território mineiro. 


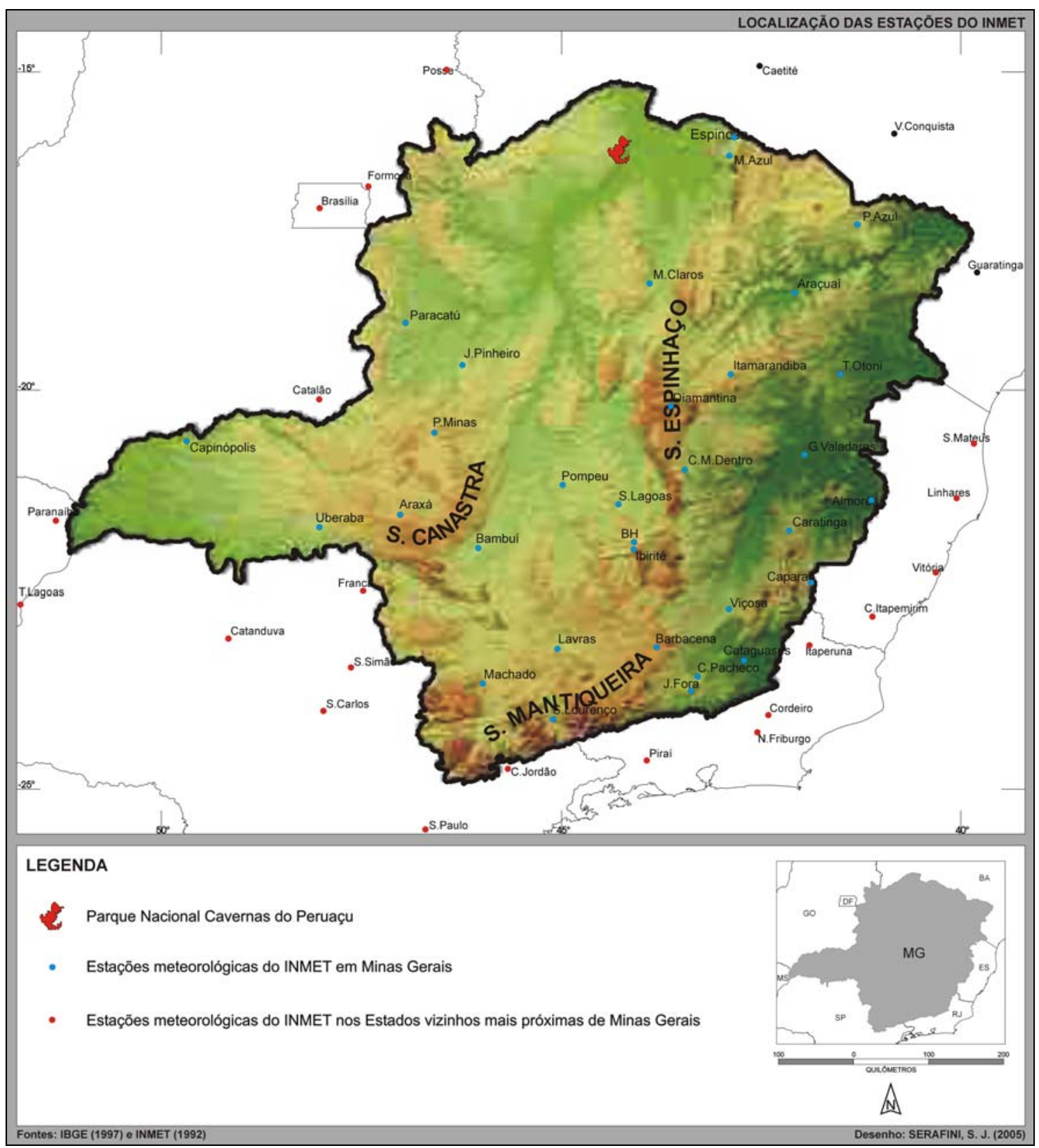

FIGURA 02: Mapa de localização das estações meteorológicas do INMET utilizadas neste estudo.

Nos ANEXOS A e B, são listados mais detalhadamente os dados das estações meteorológicas do INMET localizadas em Minas Gerais e nos Estados vizinhos consideradas para a caracterização climática regional.

Do Instituto Nacional de Pesquisas Espaciais (INPE, 2003 e 2004) foram obtidas as informações sobre a circulação atmosférica predominante sobre o Estado e Minas Gerais nos meses em que foram realizados os trabalhos de campo (julho de 2003 e janeiro de 2004), obtendo, também, as imagens do satélite METEOSAT na banda do Infravermelho termal que detecta a energia 
refletida pelas diferentes superfícies da Terra que está sendo imageada, possibilitando a observação dos sistemas atmosféricos.

Da Marinha do Brasil (2003 e 2004), foram obtidas as cartas sinóticas do mesmo período dos trabalhos de campo que foram utilizadas, complementarmente, para identificação e entendimento da circulação atmosférica atuantes sobre a área de estudo, possibilitando uma melhor compreensão da dinâmica climática.

Do Instituto Brasileiro de Geografia e Estatística (IBGE, 1997) foi adotada a malha municipal brasileira disponível em arquivo digital, para a produção do material cartográfico deste trabalho na forma de mapas climáticos em que constam os limites estaduais entre Estado de Minas Gerais e seus vizinhos e municipais de Cônego Marinho, Itacarambi e Januária.

Também do IBGE (2003 e 2004), foram utilizadas as informações cartográficas temáticas apresentadas na escala 1:5.000.000 sobre os climas, os biomas e as vegetações do Brasil.

Do Instituto Brasileiro do Meio Ambiente e dos Recursos Naturais Renováveis (IBAMA, 2005) foram utilizadas as informações recentemente produzidas pela equipe interdisciplinar responsável pelo diagnóstico do Parque Nacional Cavernas do Peruaçu, constando informações sobre a geologia, a geomorfologia, o relevo e a vegetação que compõem o Plano de Manejo desta Unidade de Conservação1.

\subsection{AS FONTES CONSULTADAS PARA A ESCALA LOCAL}

Do IBAMA (op. cit, 2005), foram obtidas as informações reunidas nos trabalhos de campo executados pela mesma equipe interdisciplinar, também, responsável pela elaboração do diagnóstico ambiental do Parque Nacional Cavernas do Peruaçu nesta escala mais detalhada.

Das informações levantadas em campo abordando aspectos físicos, bióticos e antrópicos por esta equipe foram utilizadas aquelas sobre a hidrografia, geomorfologia, vegetação, fitogeografia e padrões de uso e ocupação do solo da área de estudo e seu entorno.

1 O Plano de Manejo do Parque Nacional Cavernas do Peruaçu já foi aprovado pelo IBAMA mas até a data do fechamento deste trabalho (julho de 2005) ainda não havia sido disponibilizado para consulta. 


\subsection{OS TRABALHOS DE CAMPO}

O procedimento técnico adotado para a realização dos trabalhos de campo autorizado pelo IBAMA (ANEXOS C e D), partiu da necessidade inicial de observação geral da área de estudo com um levantamento das diferenças fisiográficas naturais e antrópicas ali presentes para a posterior coleta de dados.

Para isto, foi necessária a identificação das principais unidades de paisagem realizada inicialmente em gabinete com o uso de material cartográfico e de sensoriamento remoto, subsidiado por dados bibliográficos que serão apresentadas mais detalhadamente no Capítulo 6 deste trabalho.

Já tendo sido definidos os ambientes que seriam amostrados na área de estudo e seu entorno, foram selecionados 35 pontos identificados com a numeração seqüencial de 1 a 35.

Entre eles, alguns não puderam ser visitados nos dois trabalhos de campo em decorrência dos conflitos agrários gerados pelo processo de desapropriação das propriedades inseridas no Parque Nacional Cavernas do Peruaçu envolvendo Ministério Público, IBAMA e associação de moradores.

Outro motivo que impediu a visita nos dois trabalhos de campo de alguns pontos de amostragem foi a impossibilidade de acesso pelas péssimas condições das vias de acesso, principalmente em janeiro de 2004, período em que as chuvas dificultaram ainda mais o trânsito e até mesmo encobriram algumas das áreas visitadas em julho de 2003.

Entre os 35 pontos, aquele identificado como "Ponto 22", foi anulado devido a problemas nos registros dos dados. Portanto, todas as análises climáticas da área de estudo foram realizadas com base nos registros coletados em 34 pontos que são mostrados na Figura 03. 


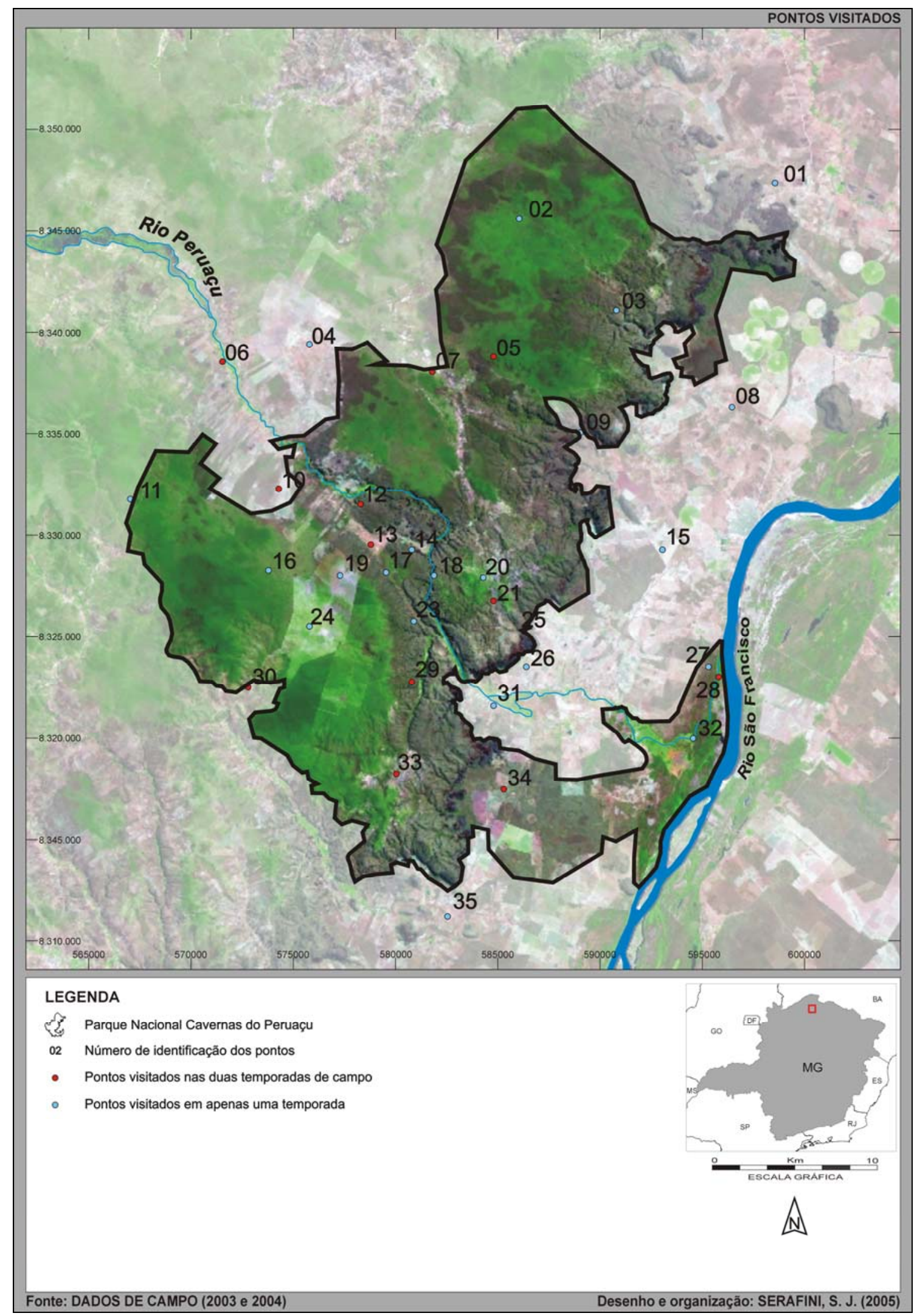

FIGURA 03: Pontos visitados (pontos de amostragem) no Parque Nacional Cavernas do Peruaçu. 
Estes registros correspondem aos dados de temperatura e umidade relativa do ar, pressão barométrica, nebulosidade e pluviosidade2, registrados entre os dias 01 a 30 de julho de 2003 e 05 a 27 de janeiro de 2004, compreendendo o intervalo horário entre $06 \mathrm{~h} 00 \mathrm{mim}$ e $18 \mathrm{~h} 00 \mathrm{mim} 3$, obtidos da seguinte forma:

Para a obtenção dos valores de pressão atmosférica registrada na área de estudo, foi utilizado um barômetro eletrônico fixado no Ponto nº 19 (UTM / X = 577.500, UTM / Y = 8.327.750, $Z=780$ metros). Segundo informação do fabricante deste equipamento, há uma margem de erro de no máximo $20 \%$.

Quanto aos dados de temperatura e umidade relativa, estes foram registrados através de instrumentos analógicos e eletrônicos (data logger) alojados em abrigos meteorológicos de madeira;

Os dados pluviométricos da área de estudo foram obtidos de três fontes distintas. São elas: (i) A primeira fonte corresponde a uma série histórica de 37 anos registrada pela Indústria de Alimentos Carambi Ltda. para controle de sua produção de tomates, localizada na depressão do rio São Francisco, dentro do perímetro urbano da cidade de Itacarambi, distando da área de estudo, aproximadamente dois quilômetros; (ii) A segunda fonte corresponde aos coletados num pluviômetro instalado no ponto $\mathrm{n}^{\circ}$. 19 especialmente para os trabalhos de campo desta pesquisa; e, (iil) A terceira fonte foi obtida de um registro histórico realizado por um funcionário do parque, próximo ao ponto $\mathrm{n}^{\circ}$. 19, sendo considerado apenas os dados correspondentes aos períodos de julho de 2003 e janeiro de 2004.

Os dados sobre nebulosidade foram obtidos através de observação direta do céu, referenciado pela escala de octantes que divide a abóbada celeste em oito partes iguais, possibilitando a inferência aproximada de quantas frações

2 Os registros pluviométricos realizados nos trabalhos de campo foram feitos durante o período ininterrupto de 24 horas, acumulando chuva iniciada entre 09h00mim de um dia e 09h00mim do dia seguinte.

3 Sobre o período de 05 a 27 de janeiro, foi considerada uma correção horária de 1 hora em decorrência do horário de verão em vigor naquele ano. 
oitavas estavam recobertas por nuvens, sendo marcada numa planilha desenhada para este fim.

$\mathrm{Na}$ fase de tratamento dos dados de nebulosidade os valores registrados na escala oitantes foram convertidos em valores relativos (\%), pretendendo uma melhor interpretação deste parâmetro.

A seguir, no Quadro 01, estão compiladas as referências básicas dos equipamentos utilizados em campo, seguidas pela Figura 04, onde estes são mostrados indexados ao Quadro 01.

QUADRO 01: Relação de instrumentos utilizados na coleta de dados primários.

\begin{tabular}{|c|c|c|}
\hline $\begin{array}{l}\text { REFERÊNCIA NA } \\
\text { FIGURA } 04\end{array}$ & INSTRUMENTO & FUNÇÃO / MEDIÇÃO \\
\hline A & $\begin{array}{l}\text { ABRIGO METEOROLÓGICO } \\
\text { PORTÁTIL DE ESTACA }\end{array}$ & PROTEÇÃO DOS INSTRUMENTOS \\
\hline B & PSICRÔMETRO ASPIRADO & $\begin{array}{l}\text { UMIDADE RELATIVA E } \\
\text { TEMPERATURA }\end{array}$ \\
\hline C & $\begin{array}{l}\text { PLUVIÔMETRO DE } \\
\text { GARRAFA }\end{array}$ & MEDIÇÃO DA ALTURA DA CHUVA \\
\hline D & TERMÔMETROS & TEMPERATURA DO AR \\
\hline E & DATA LOGGER (2 CANAIS) & $\begin{array}{l}\text { REGISTRO DE TEMPERATURA E } \\
\text { UMIDADE RELATIVA }\end{array}$ \\
\hline $\mathrm{F}$ & BÚSSOLA & ORIENTAÇÃO DO VENTO \\
\hline G & BARÔMETRO ELETRÔNICO & PRESSÃO BAROMÉTRICA \\
\hline $\mathrm{H}$ & COMPUTADOR PORTÁTIL & $\begin{array}{l}\text { COLETA E ARMAZENAMENTO DOS } \\
\text { DADOS }\end{array}$ \\
\hline I & ANEMÔMETRO & VELOCIDADE DO VENTO \\
\hline
\end{tabular}

Organização: Sergio Serafini Júnior (janeiro de 2004) 


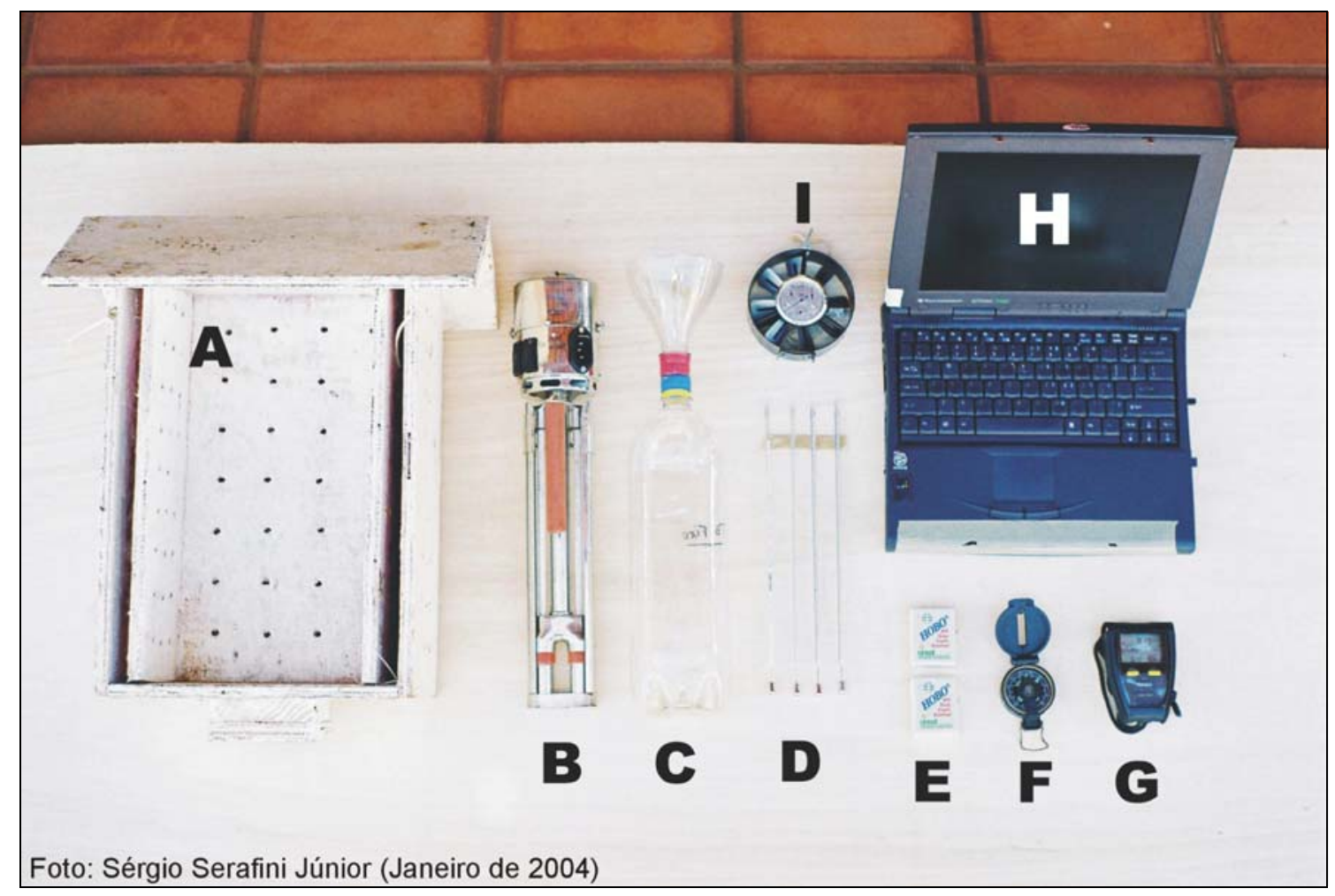

FIGURA 04: Instrumentos utilizados para registro de dados entre os dias 01 a 30 de julho de 2003 e 05 a 27 de janeiro de 2004 no Parque Nacional Cavernas do Peruaçu.

\subsection{AS TÉCNICAS ADOTADAS E A APRESENTAÇÃO DOS DADOS}

Em virtude da grande quantidade de dados registrados em campo (dados brutos) estes foram organizados estatisticamente com o objetivo de extrair as informações mais importantes para a análise proposta.

Dentro do universo estatístico, as principais técnicas aqui utilizadas correspondem à obtenção da média e da distribuição de freqüências que serão utilizadas para identificar as maiores ocorrências de um dado valor dentro do limites máximos registrados.

Como os dados registrados estão associados a um ponto dentro da área de estudo, a observância dos seus valores médios e a freqüência com que aparecem, foram utilizados como referência para se projetar as condições climáticas predominantes num determinado ambiente e num determinado período do ano.

Além do tratamento estatístico foram considerados, também, os aspectos sobre a fisionomia da paisagem e as atividades humanas associadas às condições 
climáticas médias, possibilitando a identificação de ambientes climáticos homogêneos distintos e passíveis de se constituírem como unidades.

Para a construção dos mapas climáticos foi utilizado o software SURFER (versão 7.0), que realiza projeções numéricas relacionadas a um banco de dados composto por informações sobre o eixo da coordenada (X) e abscissa (Y) e variável numérica $(Z)$ associada aos valores médios dos atributos climáticos aqui considerados.

Por se tratar de projeções automáticas, estas extrapolam informações numéricas sobre áreas não visitadas, ou seja, sobre pontos nas retas $X$ e $Y$ que não constam no banco de dados, gerando erros progressivos quanto maior for o distanciamento entre o ponto amostrado e aquele interpolado. Portanto, os mapas climáticos apresentados são aproximações do comportamento real na forma de modelos. (grifo meu)

Visando um melhor agrupamento dos valores médios e totais sazonais (verão e inverno), neste trabalho o verão corresponde ao período quadrimestral dezembro, janeiro, fevereiro e março, enquanto que o inverno corresponde aos meses de junho, julho, agosto e setembro sem, contudo, considerar as datas exatas de início e término de cada uma destas estações do ano. Por isto, neste trabalho, foi adotada a denominação de "períodos" de verão e inverno, em substituição à denominação de "estações do ano".

Quanto à radiação solar, é sabido que há uma redução de seus valores após entrar na atmosfera. Entretanto, devido à limitação instrumental não foram realizadas medições de radiação solar na superfície, utilizando-se apenas de valores estimados de radiação incidente no topo da atmosfera para elucidação dos processos climáticos ocorrentes na dimensão horizontal através da circulação atmosférica geral e regional. 
DELIMITAÇÃO DE UNIDADES CLIMÁTICAS LOCAIS NO PARQUE NACIONAL CAVERNAS DO PERUAÇU

\section{AS CARACTERÍSTICAS GERAIS DA REGIÃO DE ESTUDO}


Localizado na porção Norte do Estado de Minas Gerais, o Parque Nacional Cavernas do Peruaçu (PNCP) abrange parte dos municípios de Januária, Itacarambi e São João das Missões, totalizando uma área de 56.000 ha., como apresentado na Figura 05.

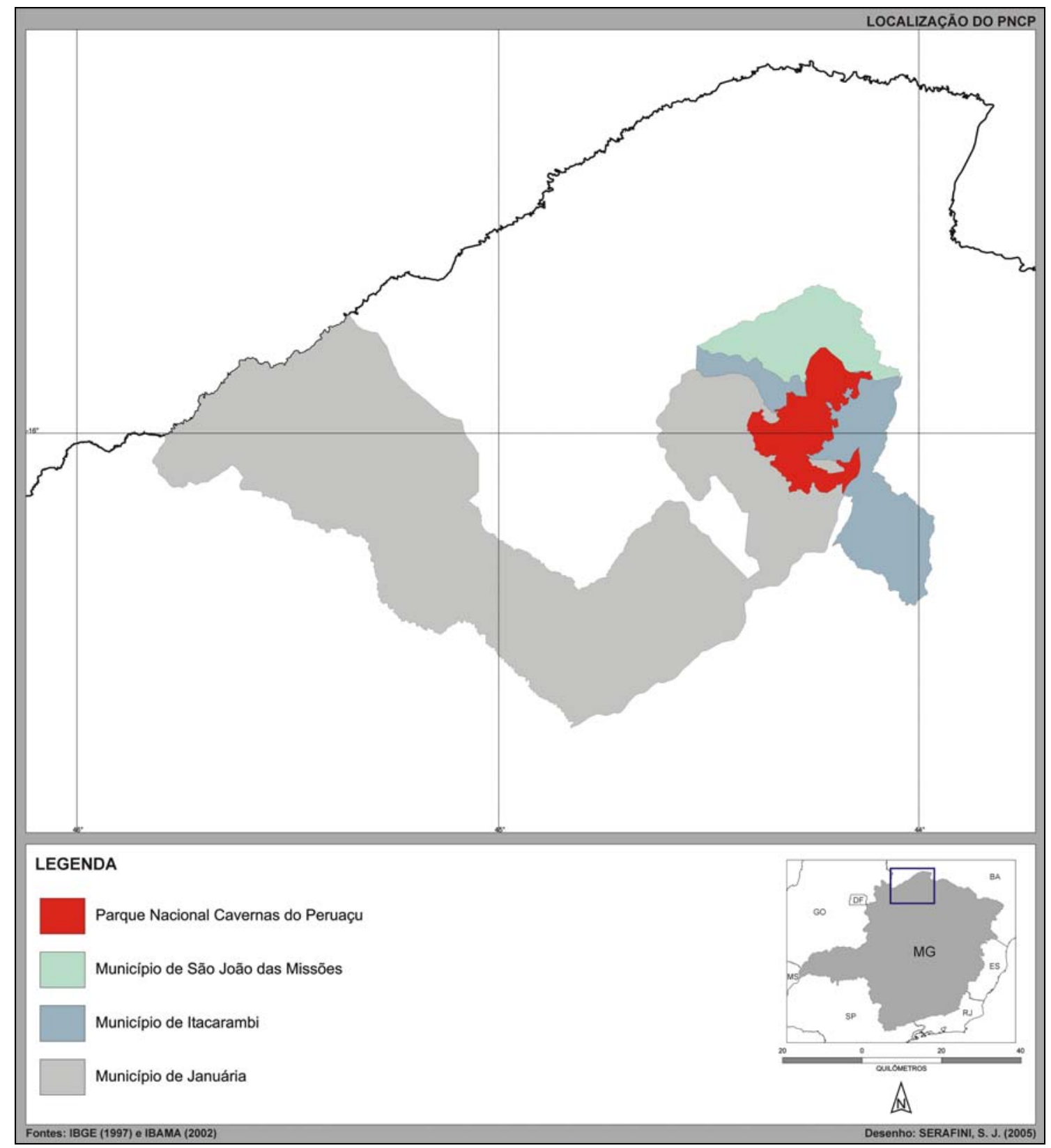

FIGURA 05: Localização do Parque Nacional Cavernas do Peruaçu.

Peruaçu é o nome dado ao rio afluente esquerdo do rio São Francisco possuindo uma extensão aproximada de $100 \mathrm{~km}$, compondo extensas veredas no seu curso médio superior que entrecortam vegetação de cerrado, vale dissecado sobre ambiente cárstico no seu curso médio inferior, finalizando seu 
trajeto no rio São Francisco que se encontra numa área deprimida e topografia predominantemente aplainada.

O seu curso médio, já encaixado sobre uma plataforma cárstica, o rio Peruaçu é considerado uma das regiões cársticas mais importantes do Estado de Minas Gerais por agregar um enorme valor científico para a arqueologia e paleontologia, contendo inúmeros sítios arqueológicos e espeleológicos com representações rupestres e material fóssil, localizados dentro dos limites do Parque Nacional Cavernas do Peruaçu (Figura 06).

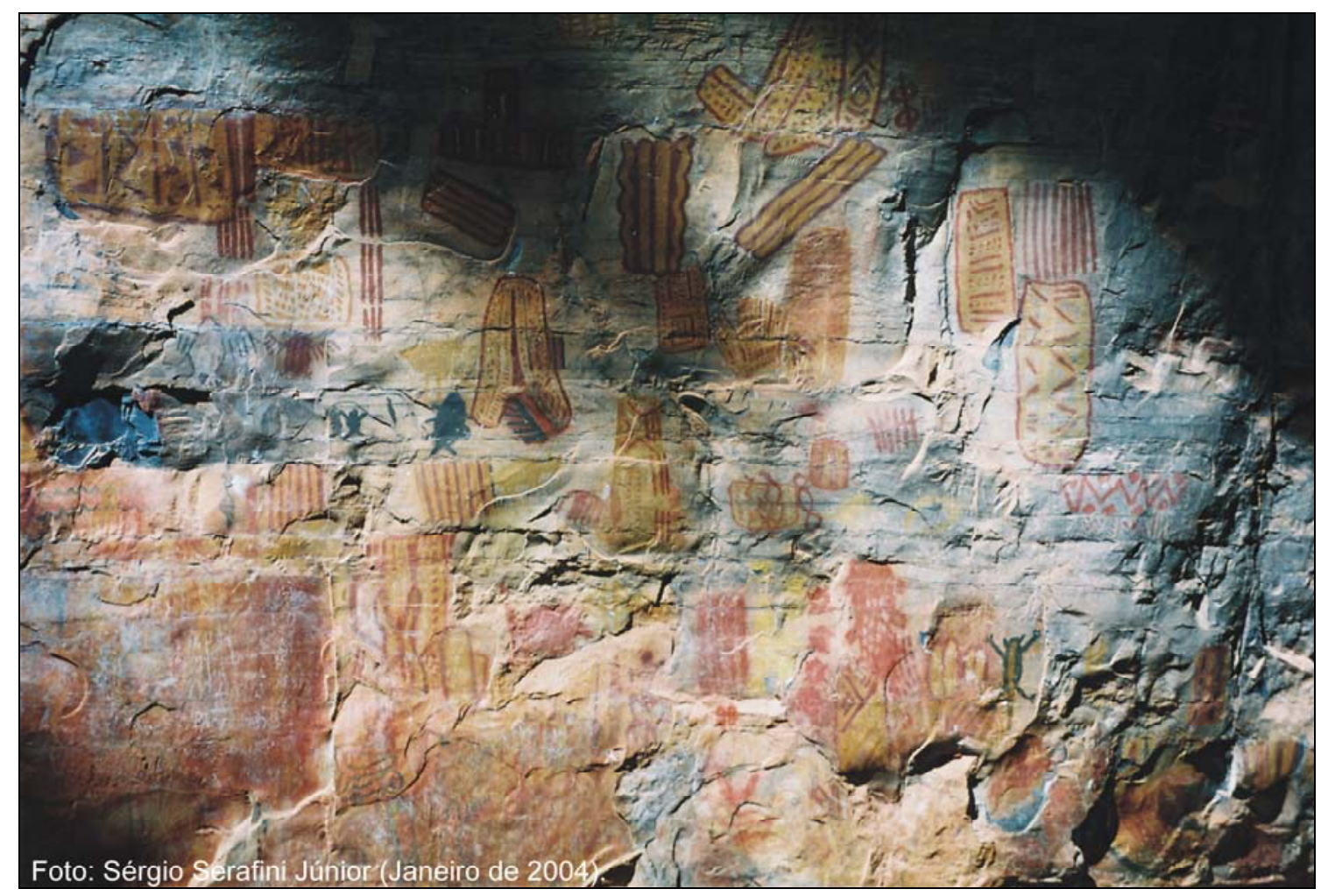

FIGURA 06: Tipo de representação rupestre encontrada no Parque Nacional Cavernas do Peruaçu.

Em vista do seu valor ecológico e científico reconhecido, nas décadas de 80 e 90 foram criadas três Unidades de Conservação, como estratégias de proteção desse patrimônio, além da proximidade de uma reserva indígena que faz divisa ao norte com o Parque Nacional Cavernas do Peruaçu.

Em 1989, por meio do Decreto $n^{\circ}$. 98.182, de 26 de setembro (ANEXO E) foi criada uma Área de Proteção Ambiental na esfera Federal, denominada APA Cavernas do Peruaçu, circundando toda a bacia hidrográfica do rio Peruaçu. 
Em linhas gerais, uma Área de Proteção Ambiental exerce o papel funcional de fixar zonas destinadas ao exercício das atividades humanas, respeitando as áreas de maior importância ecológica e de preservação permanente, garantidas legalmente pelo Código Florestal (Lei Federal $n^{\circ} .4 .771$, de 15 de setembro de 1965), onde a estratégia de gerenciamento visa compatibilizar as atividades humanas com a preservação da vida silvestre, uma vez que numa APA pode ser estabelecida em área de domínio público ou privado sem a desapropriação das terras envolvidas.

Malgrado, no âmbito da APA Cavernas do Peruaçu, tal estratégia de gerenciamento norteada pela sustentabilidade entre as atividades humanas e vida silvestre apresentou resultados pouco satisfatórios em relação à preservação das áreas naturais pretendida, sobretudo, das áreas de preservação permanente (APP), onde estão localizados os ambientes de veredas, evidenciando sérias condições de degradação decorrente do avanço de atividades agropastoris sobre elas.

De modo geral, os ambientes de veredas (Figura 07) saltam aos olhos pela diversidade biológica advinda da proximidade de cursos d'água, formando corredores contínuos de matas sendo utilizados como extensos caminhos naturais de fauna, ocupando uma condição ecológica de destaque para o equilíbrio de inúmeras espécies de animais que utiliza-os como seu berçário, fonte de alimentação e proteção da vida silvestre.

Em 27 de setembro de 1994, através do Decreto $n^{\circ}$. 36.070 (ANEXO F), foi criado o Parque Estadual Veredas do Peruaçu, sobrepondo-se a APA na porção montante da bacia do rio Peruaçu, totalizando uma área de 30.702 ha.

Caracterizando-se como um instrumento legal mais restritivo às atividades humanas, o PE Veredas do Peruaçu mantém um elevado grau de preservação dentro de seus limites.

Particularmente os limites norte, noroeste e oeste do PE Veredas do Peruaçu são ajustados ao próprio curso do rio Peruaçu (alto e médio curso), acompanha do o caudal do rio e suas veredas, favorecendo maior grau de preservação desse ambiente somente na porção pertencente a esta Unidade de Conservação (margem direita). 


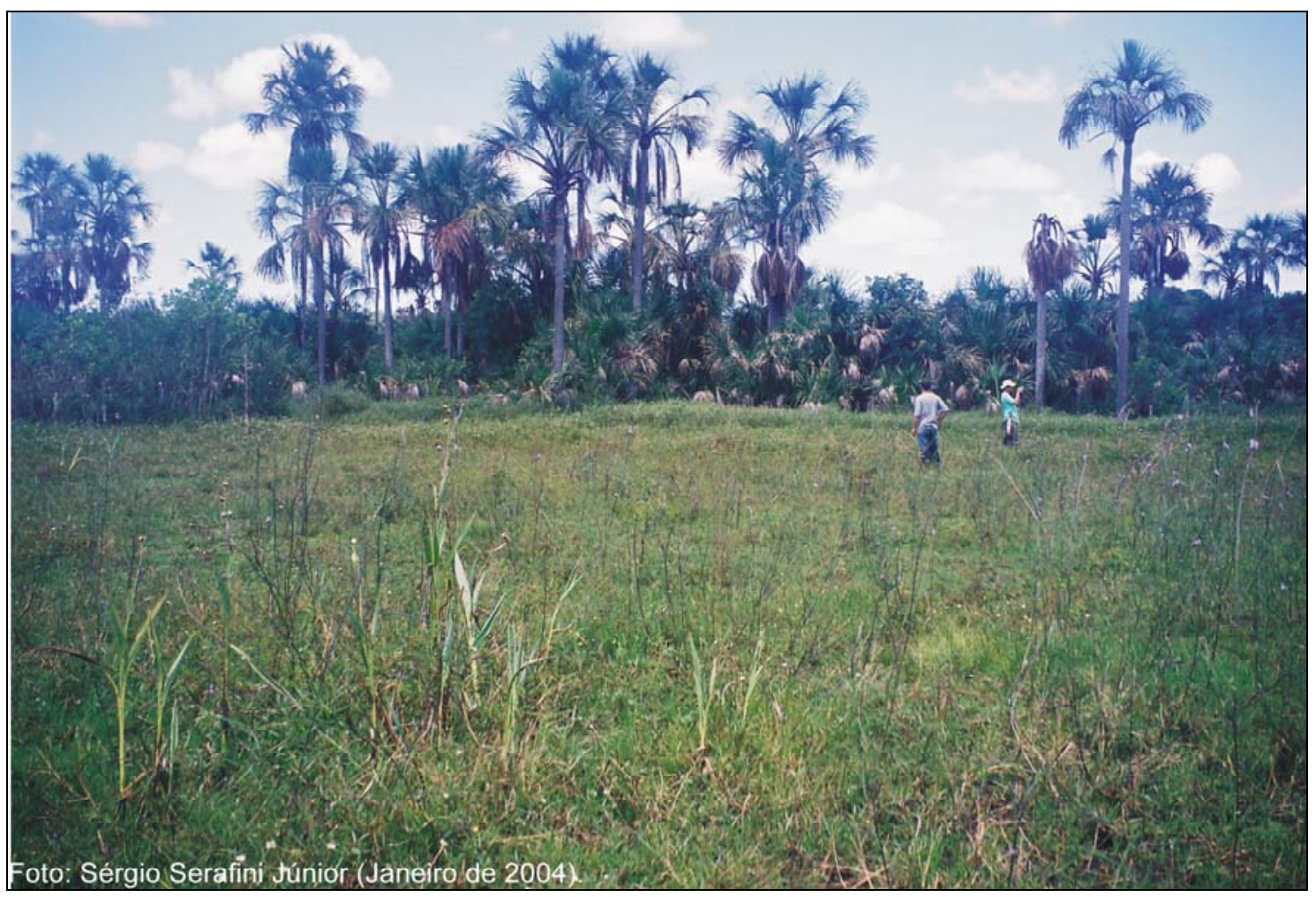

FIGURA 07: Vereda existente ao longo do alto curso do rio Peruaçu.

Paradoxalmente, na margem esquerda desse rio, isto é, fora da área de proteção desse Parque Estadual, tantos os ambientes de veredas, como o próprio cerrado evidenciam o grau de degradação decorrente das atividades humanas, contrariando os pressupostos de preservação das áreas que apresentam importância ecológica postulados para a APA Cavernas do Peruaçu.

Mediante a condição de proteção integral garantida às Unidades de Conservação enquadradas na condição de parque (Estadual e Nacional), juntamente com a importância do curso médio do rio Peruaçu, em 1999, através do Decreto de 21 de setembro (ANEXO G), foi criado o Parque Nacional Cavernas do Peruaçu que, sobrepondo-se à APA Cavernas do Peruaçu reúne uma área de 56.000 ha., dentro dos quais se encontra a formação geológica cárstica e os principais sítios arqueológicos e paleontológicos. 
Anteriormente ao ano da criação desse parque, segundo MOURA (1997):

Outra tentativa de preservação efetiva foi articulada junto a Organização das Nações Unidas para Educação, Ciência e Cultura (UNESCO), onde existe um projeto para considerar o vale do rio Peruaçu como Patrimônio Mundial da Humanidade. Em 1997, uma missão dessa instituição esteve no Brasil, visitando a região, estudando e discutindo os problemas que limitam as ações de preservação, procurando soluções e avaliando as possibilidades da solicitação de tombamento do Peruaçu. (P. 18); sem uma posição concreta (grifo meu).

Tal importância científica dada ao vale do rio Peruaçu, mais especificamente ao trecho pertencente ao Parque Nacional Cavernas do Peruaçu, está concentrada na sua estrutura cárstica que, segundo KOHLER (Apud. MOURA, 1997) "são regiões-chave para o estudo da paleontologia, arqueologia e principalmente mudanças globais ocorridas no Quaternário”.

As depressões fechadas e os condutos subterrâneos
funcionam como armadilhas para reter qualquer material
(mineral ou orgânico) existente em sua bacia. A calcita, mineral
proveniente da dissolução e precipitação das rochas
carbonáticas, funciona como uma lápide petrificada sobre
depósitos, fossilizando-os e preservando-os para serem
descobertos e analisados pelos pesquisadores que estudam o
passado de nosso planeta. (Apud, MOURA, 1997)

Na Figura 08, são apresentadas as localizações das Unidades de Conservação criadas ao longo do curso do rio Peruaçu. 


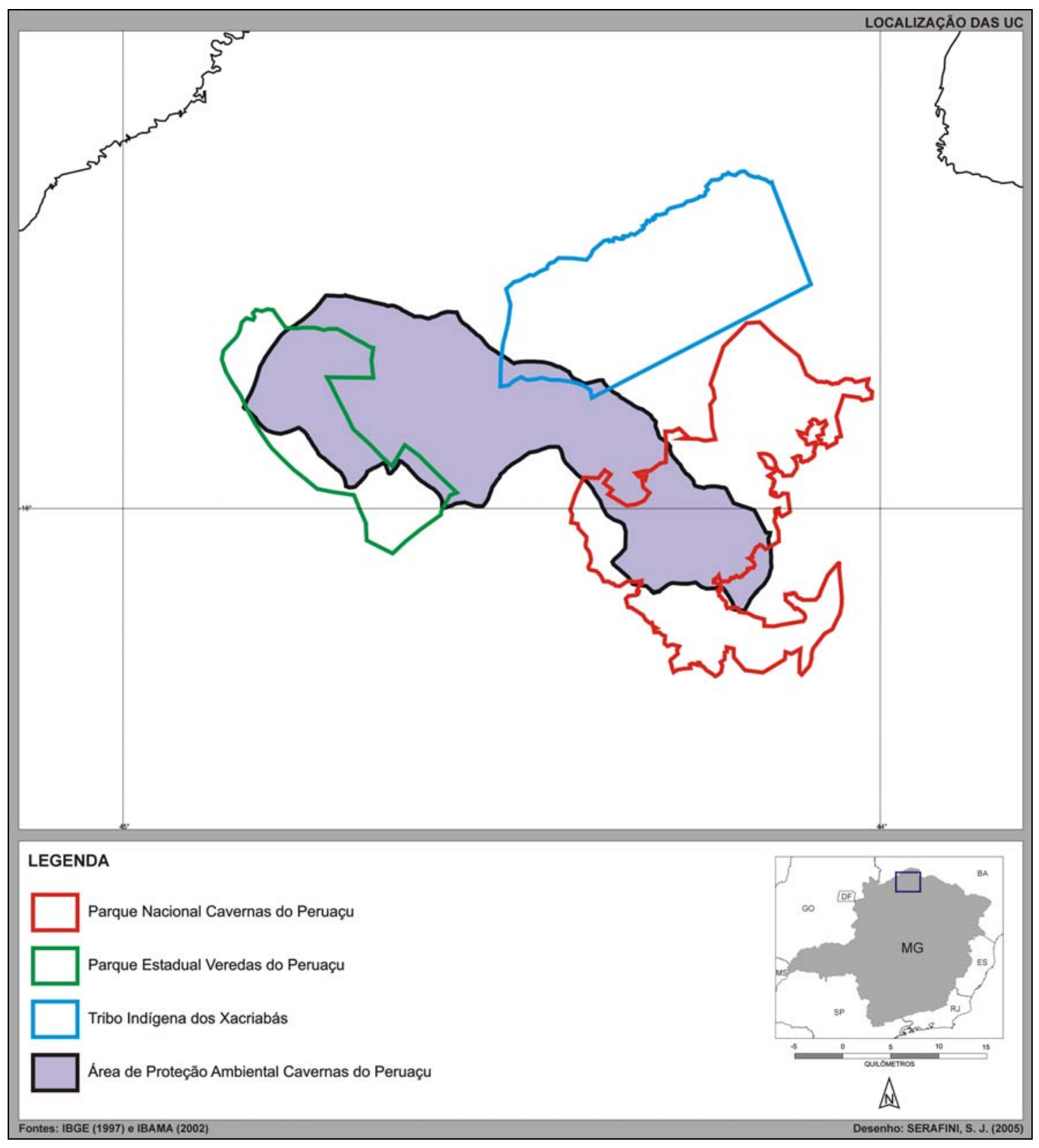

FIGURA 08: Localização da Área de Proteção Ambiental Cavernas do Peruaçu, Parque Estadual Veredas do Peruaçu e Parque Nacional Cavernas do Peruaçu.

A saber, foi no período Quaternário (1,8 milhões de anos até o presente) que ocorreram os principais processos naturais de modificações das condições ambientais que resultaram transformações mundiais significativa na paisagem para os tempos atuais, possibilitando grandes avanços no entendimento do planeta, principalmente com o uso do método de datação pelo Carbono 14.

Além da notória importância arqueológica e paleontológica voltada principalmente para pequenos grupos de pesquisadores, o Parque Nacional Cavernas do Peruaçu, é também uma área que reserva com bastante riqueza 
os aspectos naturais observados sob as categorias ecológicas e paisagísticas, sobre as quais, foi registrada uma crescente exploração turística.

Inicialmente, a criação do Parque Nacional Cavernas do Peruaçu não garantiu efetivamente sua proteção integral. Sobre isto, MOURA (op. cit. 1997) relata que na área...

Criou-se um grande e crescente interesse de firmas de turismo interessadas no chamado 'turismo ecológico. Entretanto, os órgãos de governo responsáveis pela preservação e fiscalização do uso não têm exercido essas funções, nem cumprido os compromissos com a preservação do patrimônio nacional na medida em que, a própria região necessita. Além disso, alguns proprietários locais têm-se mostrado indiferentes a toda esta ameaça de destruição, tomando atitudes que chegam a afetar a estabilidade do meio ambiente, por não serem devidamente informados a respeito das melhores alternativas de uso racional do espaço. (P. 17)

Somente após algum tempo de sua criação o Parque Nacional Cavernas do Peruaçu , o IBAMA passou controlar as atividades humanas ali pré-existentes e proibindo definitivamente o acesso de visitantes ou qualquer outro uso até a consolidação do seu Plano de Manejo.

Basicamente, um Plano de Manejo constitui-se num documento orientador de todas as atividades a serem desenvolvidas, priorizando as características de cada uma das Unidades de Conservação com o objetivo de garantir suas características originais, necessitando para isto, de um minucioso diagnóstico geo-ambiental, tornando-se obrigatório através do Sistema Nacional de Unidades de Conservação (SNUC).

No âmbito do SNUC e do Decreto de criação do Parque Nacional Cavernas do Peruaçu, mais especificamente no seu Artigo $5^{\circ}$, é disposto o prazo máximo de cinco anos para a elaboração do Plano de Manejo desta Unidade de Conservação, a contar da data de publicação deste Decreto.

Cumprindo a exigência legal, o Plano de Manejo foi elaborado tendo a participação multidisciplinar de técnicos especializados na análise dos 
parâmetros físicos, bióticos e antrópicos que, com a autorização do IBAMA, muitas informações foram aproveitadas para este trabalho.

\subsection{ASPECTOS SOBRE GEOLOGIA E GEOMORFOLOGIA}

A paisagem da região de estudo se insere no contexto da margem esquerda do rio São Francisco, sendo fortemente condicionada pelo arcabouço geológico da região na qual está inserida, com altitudes que variam entre $440 \mathrm{~m}$ na depressão do rio São Francisco e 830 m no planalto.

Segundo ROBERTSON (Apud, IBAMA, 2005), o vale do rio São Francisco apresenta entre 20 e $30 \mathrm{~km}$ de largura, com um fundo aluvial relativamente plano, sendo margeado por escarpamentos erosivos abruptos, com pelo menos $200 \mathrm{~m}$ de altitude que se desenvolveram em camadas sub-horizontais de sedimentos carbonáticos do Grupo Bambuí.

Os poucos cursos d'água perenes que cortam estas escarpas apresentam um entalhamento vertical muito acentuado em relação a sua largura.

O rio Peruaçu, que é uma destas drenagens perenes, nasce na região de planaltos desenvolvidos sobre os pacotes sedimentares (arenitos, siltitos e concreções látero-manganesíferas), de idade Cretácea, da Formação Urucúia.

No seu médio curso, flui sobre as rochas carbonáticas e pelíticas, de idade Proterozóica, do Grupo Bambuí e, posteriormente, em seu baixo curso, na depressão do rio São Francisco, sobre coberturas inconsolidadas, de idade Cenozóica.

De acordo com RADAMBRASIL (Apud, IBAMA, 2005.), a evolução geomorfológica da região do alto e médio curso do rio São Francisco, teve como condicionantes iniciais os eventos geológicos do Pré-Cambriano.

As características geomorfológicas atuais foram impressas nesse arcabouço geológico pretérito, resultantes de uma evolução iniciada no Cretáceo Superior e desenrolada, principalmente, durante a Era Cenozóica, quando se delinearam as configurações atuais.

King (Apud, IBAMA, 2005), descrevendo a geomorfologia do "Brasil Oriental", definiu cinco ciclos erosivos que reduziram a paisagem do Brasil Central à condição de aplainamento em escala regional. 
Segundo este autor (op. cit., 2005), durante o Jurássico, se desenvolveu um ciclo erosivo anterior à separação Brasil-África, que reduziu a paisagem à condição de aplainamento excepcionalmente intenso. Este ciclo foi denominado de Superfície Gondwana e representa, na área de estudo, o hiato erosivo que corta as rochas carbonáticas do Grupo Bambuí.

Posteriormente, no Cretáceo, em função do arqueamento crustal que culminou com a separação Brasil-África, ocorreu um rejuvenescimento do relevo, que alterou o nível de base e favoreceu uma intensa sedimentação. Este ciclo se encerrou com extenso aplainamento, que foi denominado pelo mesmo autor de Pós-Gondwana, sendo responsável pela deposição da Formação Urucuia.

A partir do soerguimento continental oligocênico, que culminou com a instalação do rift sanfranciscano, iniciou-se o ciclo erosivo-deposicional da Superfície Sulamericana, caracterizado pela ocorrência de solos de caráter colúvio-aluvionares, que mantêm sua integridade sobre os diferentes tipos litológicos que recobrem.

De acordo com Braun (Apud, IBAMA, 2005.), todo o relevo atual do Brasil foi esculpido sobre esta superfície, através dos ciclos erosivos posteriores. Segundo King (Apud, IBAMA, 2005.), depósitos sedimentares encontrados em cavernas da região central de Minas Gerais indicam que as mesmas foram abertas abaixo do planalto terciário correspondente a esta superfície.

Com a execução de trabalhos de campo para elaboração do Plano de Manejo do Parque Nacional Cavernas do Peruaçu foi realizado um levantamento geomorfológico mais recente (IBAMA, 2005) com a delimitação de quatro unidades distintas apresentadas a seguir.

Compartimento da Depressão do São Francisco

Este compartimento da Depressão do São Francisco está localizado entre 440 e 500 metros de altitude, sendo marcado por um relevo aplainado com ondulações suaves e morros testemunhos de rochas carbonáticas que se ressaltam em meio à planície.

A origem da depressão é associada à dinâmica do rio São Francisco (Figura 09), que preencheu uma área rebaixada por abatimento tectônico, com depósitos coluvionares e aluvionares. 
A presença de morros testemunhos dos calcários, imersos nos sedimentos da planície, constitui uma evidência do recuo da escarpa calcária no sentido oeste, através de erosão remontante.

É um compartimento intensamente ocupado por atividades antrópicas voltadas, predominantemente, para produção pecuária de corte.

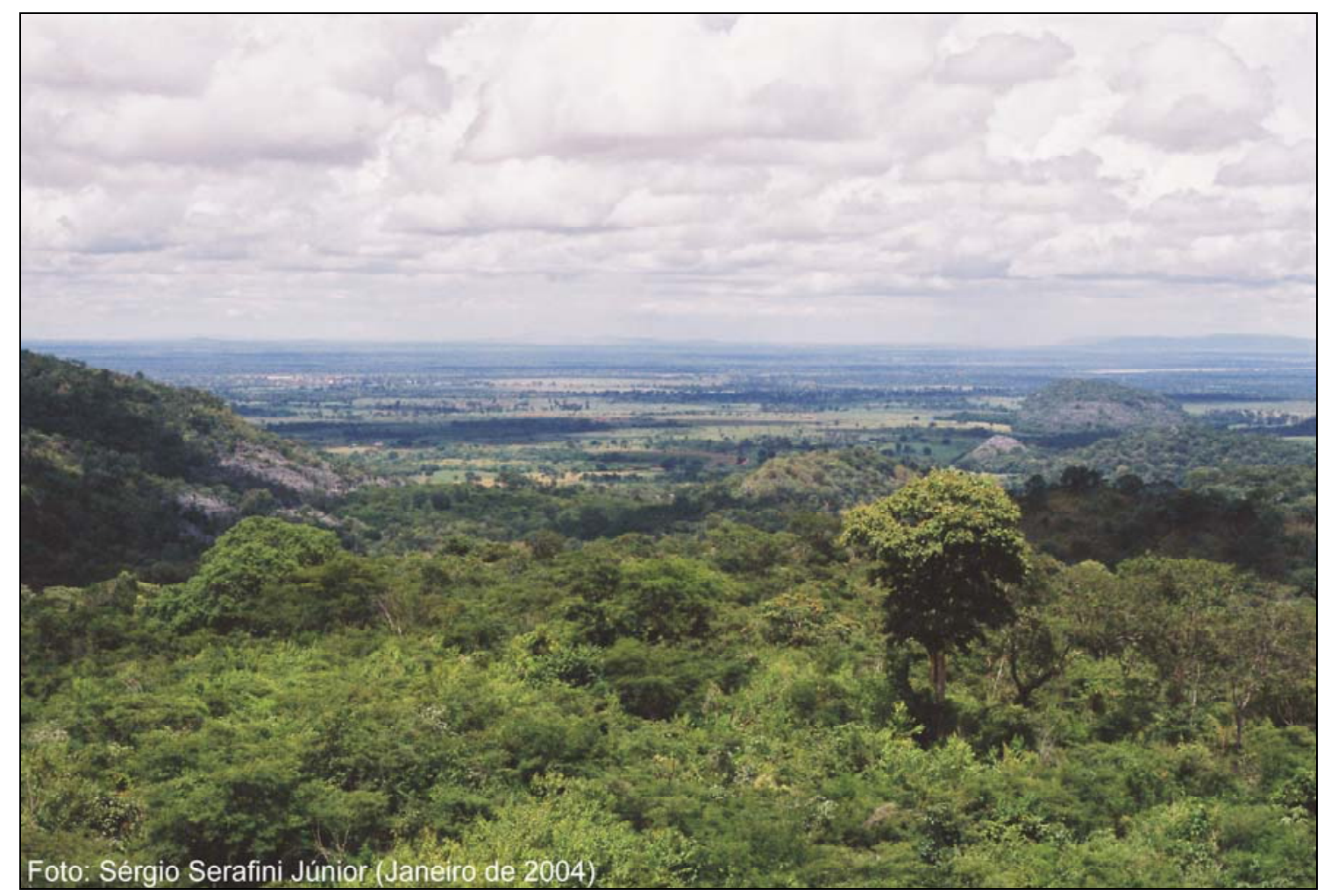

FIGURA 09: Trecho do compartimento geomorfológico da Depressão do São Francisco.

- Compartimento Carstificado

Este compartimento carstificado está situado entre 500 e 720 metros de altitude, caracteriza-se pelo relevo acidentado decorrente a sua litologia calcária, passível de dissolução e pela ausência de uma rede de drenagem contínua, exibindo grande variedade de feições cársticas, tais como cavernas, dolinas de abatimento, vales cársticos, maciços fissurados, torres ruiniformes, sumidouros, ressurgências, paredões escarpados e caneluras de dissolução de variadas dimensões, restringindo o grau de uso e ocupação do solo (Figura 10). 


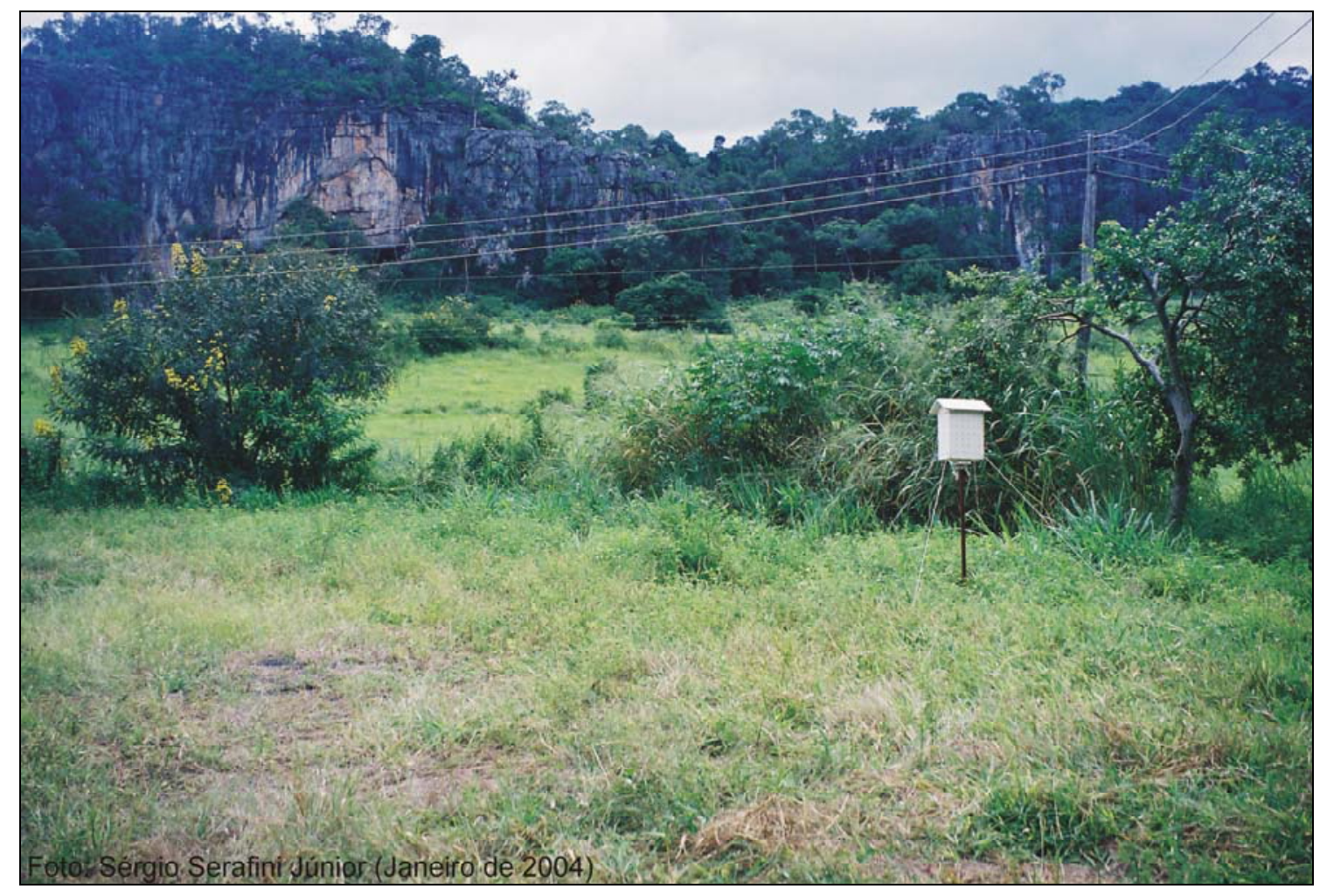

FIGURA 10: Trecho do compartimento carstificado.

- Compartimento da Zona de Transição

Este compartimento da zona de transição está situado, aproximadamente, entre as cotas 720 e 760 metros e caracteriza-se pela ocorrência de um relevo aplainado (Figura 11), cuja monotonia da paisagem é quebrada pela presença de morros tabulares, marcando a transição entre o relevo de baixos gradientes do Planalto dos Gerais (descrito a seguir) e o relevo acidentado do Compartimento Cárstico. 


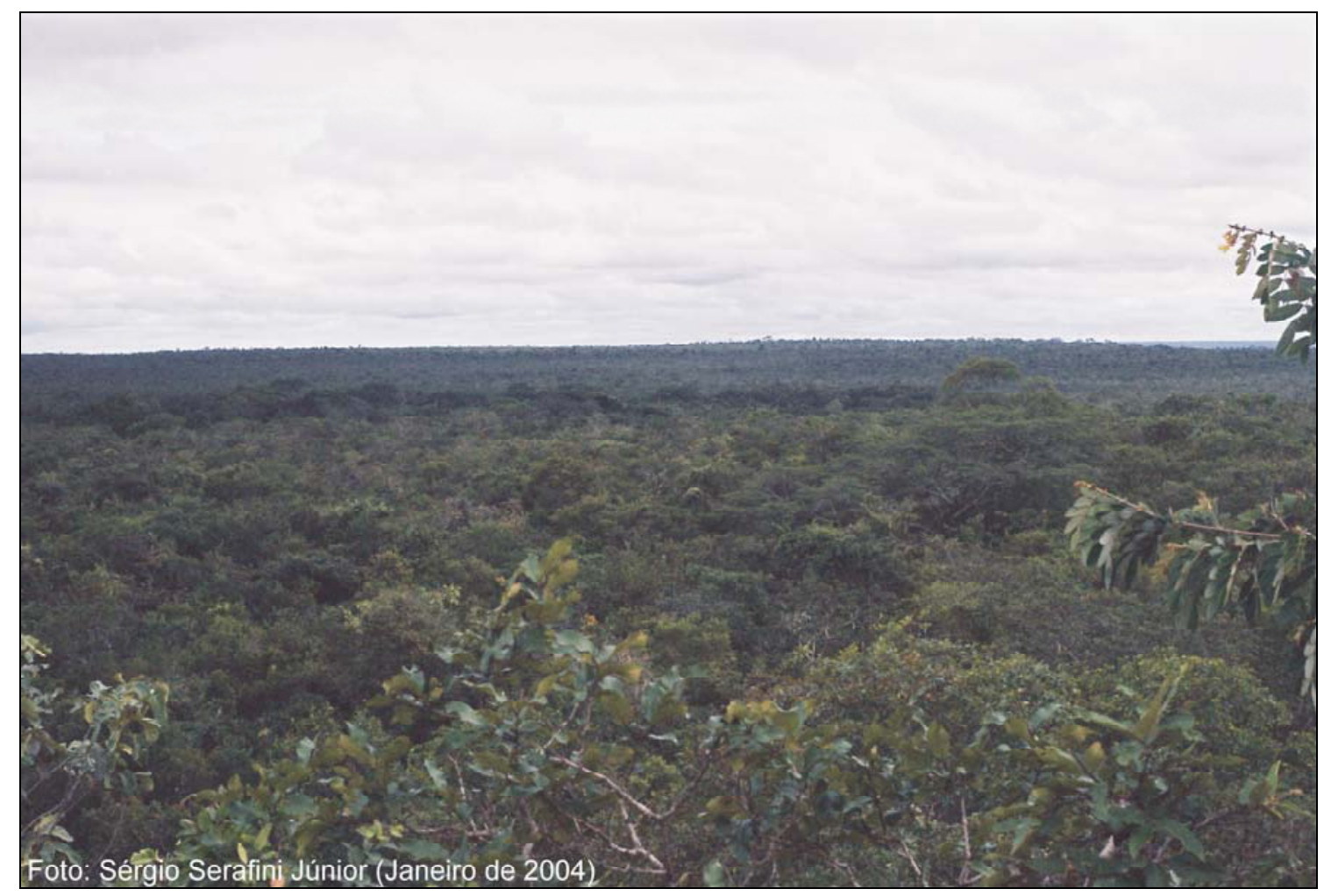

FIGURA 11: Trecho da Zona de Transição.

- Compartimento do Planalto dos Gerais

Este compartimento do planalto dos gerais está situado acima da cota 760 metros, sendo marcado por um relevo aplainado, com ondulações suaves e amplos interflúvios, evoluindo para uma chapada a partir da cota $800 \mathrm{~m}$, onde se observa uma paisagem de topo plano com densidade de drenagens muito baixa (Figura 12).

Neste compartimento situam-se as cabeceiras e o alto curso do rio Peruaçu que, neste trecho, apresenta-se na forma de veredas, em função dos baixos gradientes e do afloramento do nível d'água, sendo caracterizado por extensas planícies inundadas. 


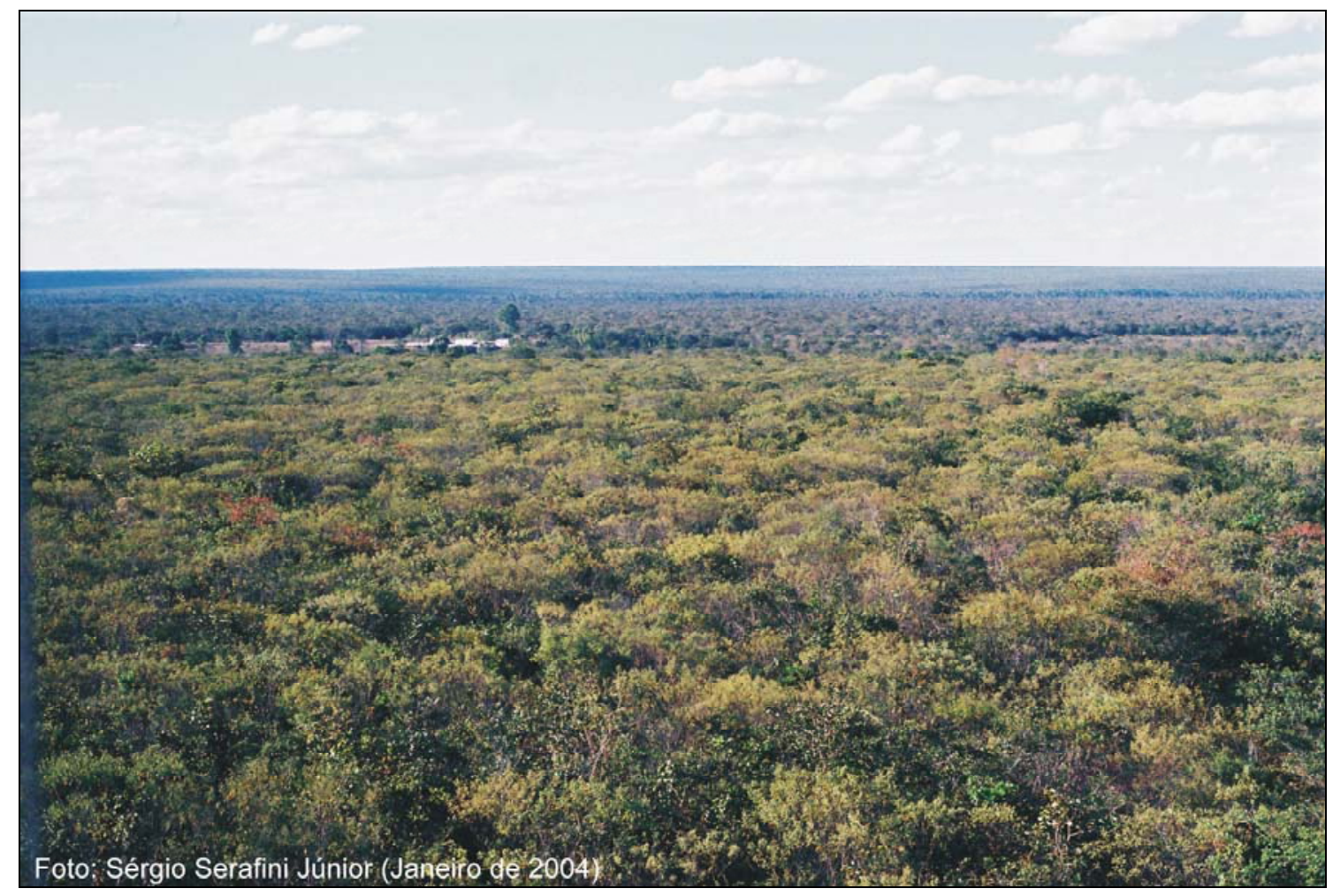

FIGURA 12: Trecho do compartimento do Planalto dos Gerais.

A seguir, na Figura 13, é apresentada a distribuição dos compartimentos geomorfológicos do Parque Nacional Cavernas do Peruaçu. 


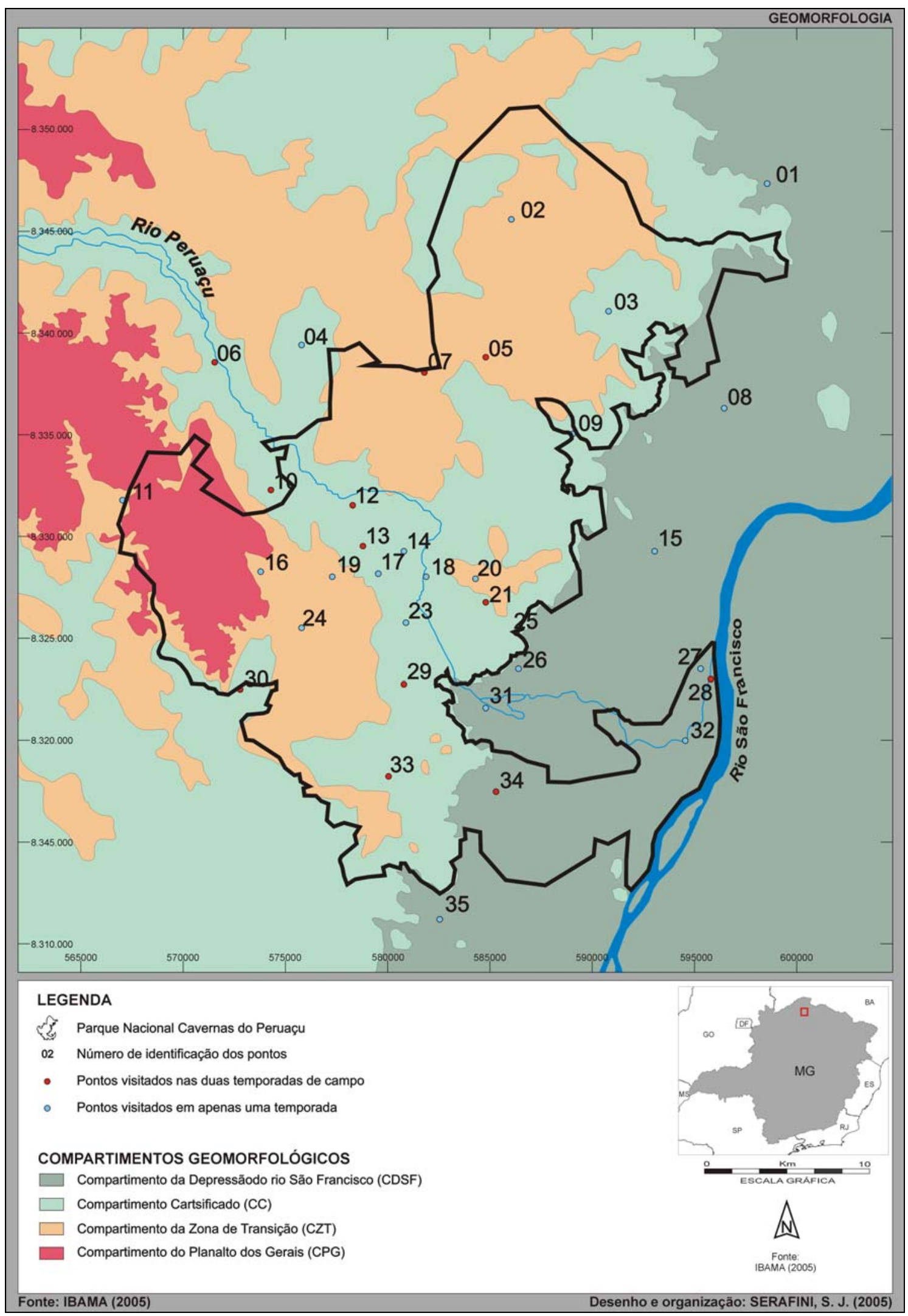

FIGURA 13: Compartimentos geomorfológicos do Parque Nacional Cavernas do Peruaçu. 


\subsection{ASPECTOS SOBRE A COBERTURA VEGETAL}

Com base na distribuição dos biomas brasileiros apresentada pelo IBGE (2004) e adotada neste trabalho, no Estado de Minas Gerais são encontrados os Biomas Mata Atlântica, Cerrado e Caatinga, dentre os quais apenas o Cerrado e a Caatinga são encontrados na região de estudo.

O Bioma Cerrado, também reconhecido como savana, caracteriza-se pela existência de dois estratos que se caracterizam assim: (I) estrato arborescente de pequenas árvores tortuosas, espaçadas e ditadas de cascas espessas e comumente corticosa, macia à unha; e, (ii) estrato baixo formado por gramíneas, subarbustos e arbustos.

Segundo DIAS (Apud, PEIXOTO \& LÍDIO, 1993):

Os cerrados se encontram assentados sobre sedimentos do período Terciário, que formam as superfícies de pediplanos [...]. Essas superfícies funcionam como gigantescas esponjas (sic) que retêm temporariamente as águas das chuvas que se infiltram nos solos, liberando-as lentamente, durante os meses de seca, alimentando assim, as nascentes dos riachos e veredas.

No período anual mais seco, a vegetação savanícola apresenta sua fisionomia mais ressecada onde as gramíneas ficam mais pardacentas e fáceis de queimar, o solo ressecado e duro na superfície e as árvores parcialmente desfolhadas, aspecto este que lhes confere a qualidade semidecidual.

Segundo o IBGE (op. cit., 2005) a cobertura vegetal predominante no Cerrado é constituída pelas Formações Savânica e Florestal e são encontradas nas seguintes fisionomias:

- Savana Florestada (cerradão);

- Savana Arborizada (cerrado);

- Savana Parque (campo cerrado); e,

- Savana Gramíneo-Lenhosa (campo graminoso).

Especificamente a Savana Arborizada, encontrada na área mapeada, constituise numa vegetação semidecídua composta por um estrato arbóreo formado por 
elementos xeromorfos entre três e 10 metros de altura, um estrato arbustivo, também composto por elementos xeromorfos e um estrato herbáceo composto de gramíneas.

Quanto à Formação Florestal, esta é composta pelas seguintes florestas:

Floresta Estacional Decidual (Floresta Tropical Caducifólia); e,

Floresta Estacional Semidecidual (Floresta Tropical Subcaducifólia).

Ambas estão associadas ao clima com duas estações bem marcadas, tendo como efeito a estacionalidade foliar dos elementos arbóreos dominantes que estão adaptados à estação da seca.

A diferença entre estas duas formações florestais está na quantidade de perda foliar em relação ao tempo de estiagem. Enquanto que na Floresta Estacional Semidecidual há uma perda de 20 a $50 \%$ de folhas, na Floresta Estacional Decidual essa perda fica acima dos $50 \%$.

Essa variação está relacionada diretamente com a capacidade de armazenamento de água no solo. Isto é, solos mais profundos possuem mais capacidade de retenção, condicionando o predomínio da vegetação decidual.

\begin{abstract}
[...] não existe uma divisão exata entre estas formações vegetais, mas um gradiente no incremento da biomassa, iniciando com a presença exclusiva de gramíneas (campo graminoso), aumentando aos poucos a densidade e o porte de indivíduos lenhosos (arbustos, arvoretas e árvores) até atingir uma estrutura florestal, quando se caracteriza o cerradão. Portanto, existem situações intermediárias que tanto podem ser definidas numa categoria como em outra, sendo bastante subjetivo o ponto exato de separação. O porte da cobertura vegetal aumenta em uma razão direta com a fertilidade e profundidade do solo, desde o campo graminoso até o cerradão. (op. cit. IBAMA, 2005)
\end{abstract}

Quanto à Caatinga, sua mais importante tipologia vegetal é a Savana Estépica que se constitui como uma vegetação estacional decidual, tipicamente campestre, em geral com espécies lenhosas, espinhosas, suculentas e que nascem sobre solo raso e quase sempre pedregoso. São árvores baixas, 
raquíticas, com troncos finos, muitas vezes microfoliadas ou providas de acúleos, a maioria delas adaptada fisiologicamente à escassez de água.

Na caatinga, os contrastes fisionômicos são bem acentuados entre as estações das chuvas quando a vegetação é tomada por folhagem verde e da seca quando a vegetação perde suas folhas e é tomada pela cor acinzentada.

Em relação à Caatinga, FERNANDES (Apud, IBAMA, 2005) divide-a em três categorias:

Caatinga, propriamente dita, que correspondem a diversas comunidades vegetais xéricas, garranchentas, por vezes com plantas espinhosas, suculentas ou áfilas, com intensa caducifolia no estio e variando entre o padrão arbóreo e arbustivo, definidas como caatinga, agreste, sertão e seridó, podendo ser agrupada em caatinga arbórea e caatinga arbustiva;

Carrasco que possui aspecto arbustivo-arbóreo, denso, em regra não espinhento, com indivíduos delgados portadores de ramificações muito intricadas, duras e difíceis de varar e, praticamente, sem estrato herbáceo, podendo, também, ser uma mescla de espécies de cerrado e caatinga;

Formações Residuais da própria caatinga que incluem matas úmidas, matas secas (Floresta Estacional Decidual) cerradão, cerrado, palmeirais e campos.

No âmbito da área de estudo, o Parque Nacional Cavernas do Peruaçu encontra-se inserido em região de transição entre os Biomas Cerrado e a Caatinga, onde são encontrados diferentes tipos de vegetação, existindo na maioria das vezes, comunidades indiferenciadas onde as floras se interpenetram constituindo as transições florísticas ou contatos edáficos.

Especificamente em relação à caatinga, na classificação tipológica da vegetação elaborada pelo IBGE (op. cit. 2004) a região de caatinga existente próxima à área de estudo, configura-se como uma Área de Tensão Ecológica onde são encontradas associações da Savana Estépica (caatinga propriamente dita) com as Formações Florestais Deciduais e Semideciduais (denominadas de matas secas) e de Savana em função da localização em áreas serranas, brejos e outros bolsões que apresentam condições climáticas mais amenas. 
Assim, de acordo com a divisão fitogeográfica apresentada pelo IBGE (op. cit., 2004) na escala 1:5.000.000 e projetada na área de estudo são encontradas as seguintes fisionomias vegetais:

Floresta Estacional Decidual, localizada nas porções centro e centro-oeste, formando uma faixa alongada no sentido nordeste - sudoeste;

Floresta Estacional Semidecidual, fazendo limite com a Floresta Estacional Decidual, ocupando a faixa oriental da área de estudo;

Área de Tensão Ecológica, representando uma faixa de contato entre a Savana Estépica e Floresta Estacional, ocupando as áreas próximas ao curso do rio São Francisco; e,

Avizinhando-se aos limites oeste e leste do Parque Nacional Cavernas do Peruaçu, está a Savana Arborizada e a Floresta Estacional Decidual com vegetação secundária e atividades agrárias, como mostra a Figura 14.

Para tal distribuição, cabe observar que a escala adotada pelo IBGE (op. cit. 2004), traz consigo as generalizações espaciais inerentes a ela, impossibilitando a identificação detalhada das variações contidas nestas categorias abrangentes de formação vegetal ali presentes onde são encontradas com bastante freqüência as vegetações secundárias e as atividades agrárias tanto dentro, como fora da área de estudo.

Sobre isto, BERTRAND, (Op. Cit, 1971) afirma que "a noção de escala é inseparável do estudo da paisagem", desde que considerada tanto no espaço e no tempo, dentro da qual são reunidos elementos da paisagem que apresentam certo grau de homogeneidade que se sob/sobrepõem hierarquicamente aos níveis escalares superior/inferior. (grifo meu)

No levantamento fitogeográfico realizado numa escala mais detalhada para a elaboração do Plano de Manejo do Parque Nacional Cavernas do Peruaçu, foram identificadas diferentes fisionomias vegetais, ratificando a condição fisiográfica em que a área de estudo está numa zona de transição entre o cerrado e a caatinga, além da ocorrência de áreas de tensão ecológica.

Nos resultados apresentados pela equipe de biólogos, foram identificados dez tipos de vegetação diferenciados por detalhes específicos à particularidade de cada ambiente visitado que, como tal, se limitavam a pequenas manchas 
formando um complexo mosaico de tipos de vegetação que poderiam seguramente representar unidades de paisagem menores enquadradas na escala dos geótopos fugindo, portanto, da escala de análise proposta no início deste trabalho. Estes dez tipos de vegetação são:

- Floresta estacional semidecidual;

- Vegetação secundária de floresta estacional decidual;

- Savana florestada;

- Savana arborizada fechada ou savana estépica;

- Savana arborizada aberta;

- Vegetação secundária de savana ou campo cerrado;

- Floresta estacional decidual sanfranciscana;

- Floresta estacional decidual do carste;

- Vegetação hiperxerófila; e,

- Campos hidromórficos.

Adequando tal nível de detalhamento à escala das unidades de paisagem dos geossistema e geofácie estes 10 tipos de vegetação foram reagrupados segundo a um grau de homogeneidade fisionômica mais abrangente e representada pelo nível das formações vegetais que, neste trabalho foram classificadas segundo a seguinte divisão taxonômica:

- Formação Florestal (FFL), (Figura 16);

- Formação Savânica (FSA), (Figura 17);

- Formação Savânica Estépica (FSE), (Figura 18) 


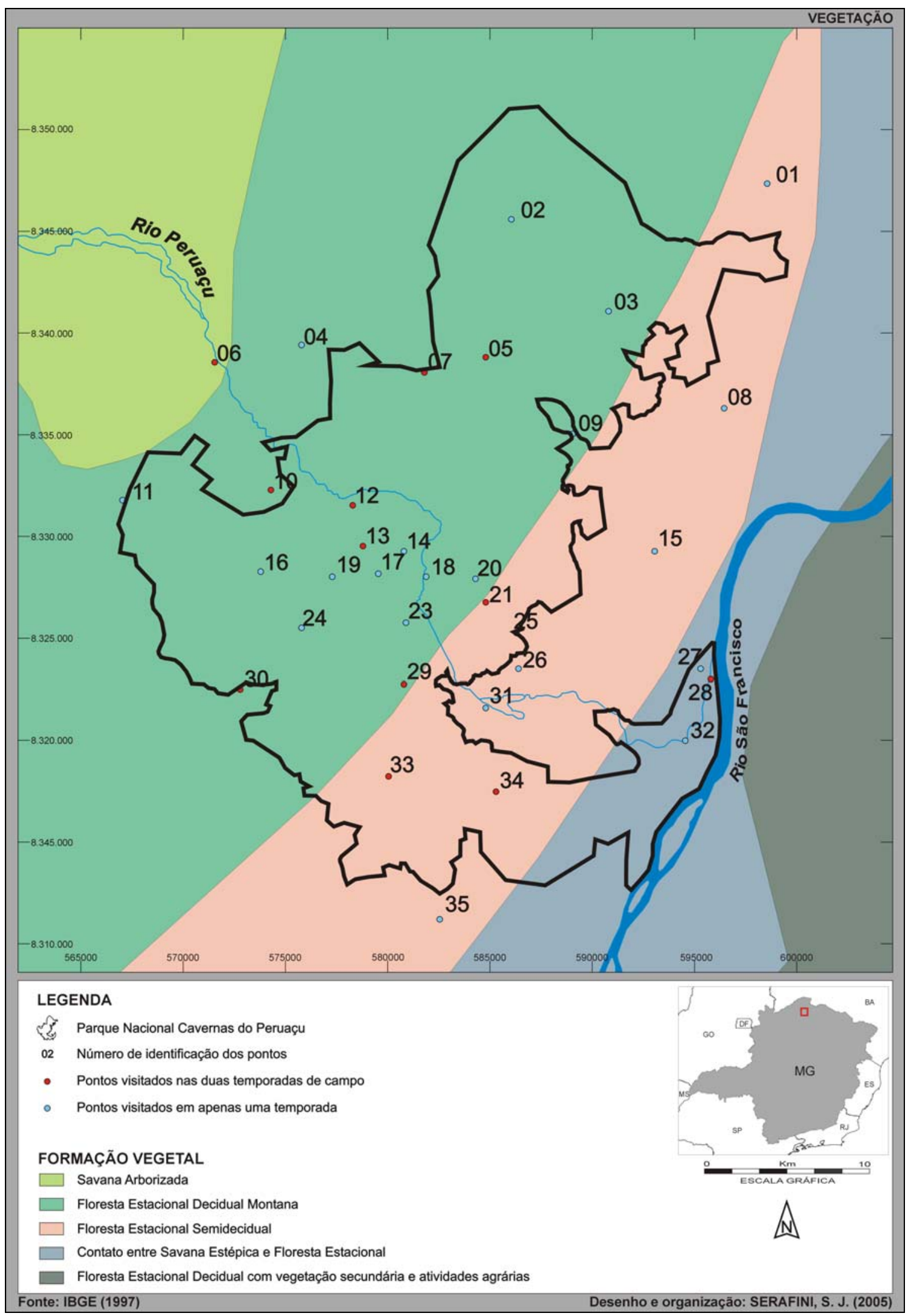

FIGURA 14: Formações vegetais definidas pelo IBGE (2004) na escala 1:5.000.000 presentes no Parque Nacional Cavernas do Peruaçu. 
Para o melhor entendimento, no Quadro 02, estão relacionadas às formações vegetais que foram agrupadas para este trabalho segundo os tipos de vegetação definidas no Plano de Manejo e apresentadas na Figura 15.

Em relação às áreas identificadas naqueles resultados como pastagem, plantações, urbanização (vilarejos, bairros rurais e cidades) e áreas degradadas, neste trabalho, foram agrupadas na categoria de Ambientes Antropizados (ANT).

QUADRO 02: Enquadramento dos agrupamentos vegetais segundo suas respectivas formações.

\begin{tabular}{|c|c|}
\hline AGRUPAMENTO VEGETAL & FORMAÇÃO \\
\hline FLORESTA ESTACIONAL SEMIDECIDUAL & \multirow{4}{*}{ FORMAÇÃO FLORESTAL } \\
\hline $\begin{array}{l}\text { VEGETAÇÃO SECUNDÁRIA DE FLORESTA ESTACIONAL } \\
\text { DECIDUAL }\end{array}$ & \\
\hline FLORESTA ESTACIONAL DECIDUAL SANFRANCISCANA & \\
\hline FLORESTA ESTACIONAL DECIDUAL DO CARSTE & \\
\hline SAVANA FLORESTADA & \multirow{3}{*}{ FORMAÇÃO SAVÂNICA } \\
\hline SAVANA ARBORIZADA ABERTA & \\
\hline $\begin{array}{l}\text { VEGETAÇÃO SECUNDÁRIA DE SAVANA OU CAMPO } \\
\text { CERRADO }\end{array}$ & \\
\hline SAVANA ARBORIZADA FECHADA OU SAVANA ESTÉPICA & \multirow{3}{*}{$\begin{array}{l}\text { FORMAÇÃO SAVÂNICA } \\
\text { ESTÉPICA }\end{array}$} \\
\hline VEGETAÇÃO HIPERXERÓFILA & \\
\hline CAMPOS HIDROMÓRFICOS & \\
\hline
\end{tabular}

Fonte: IBAMA (2004) 


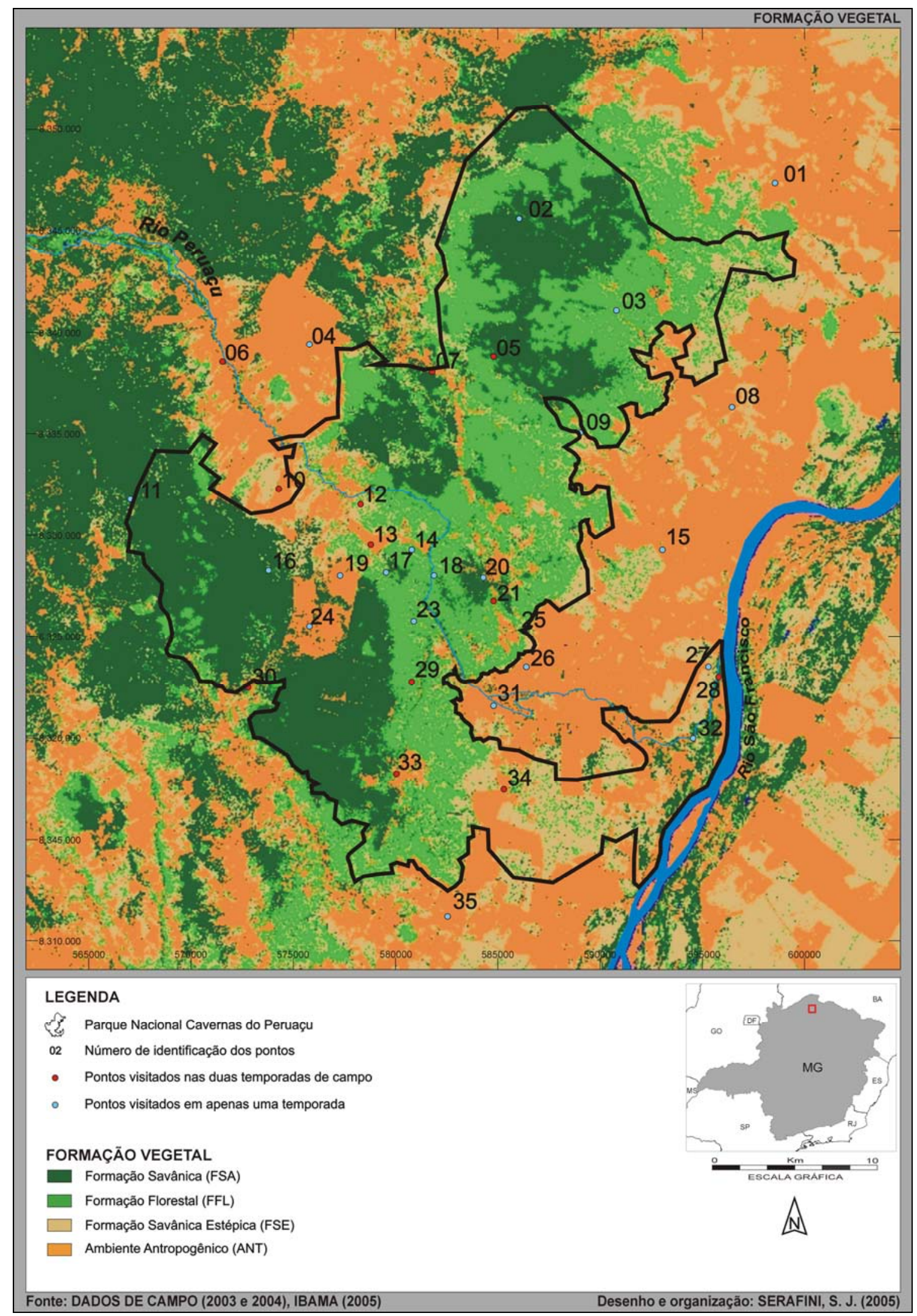

FIGURA 15: Formações vegetais predominantes no Parque Nacional Cavernas do Peruaçu. 


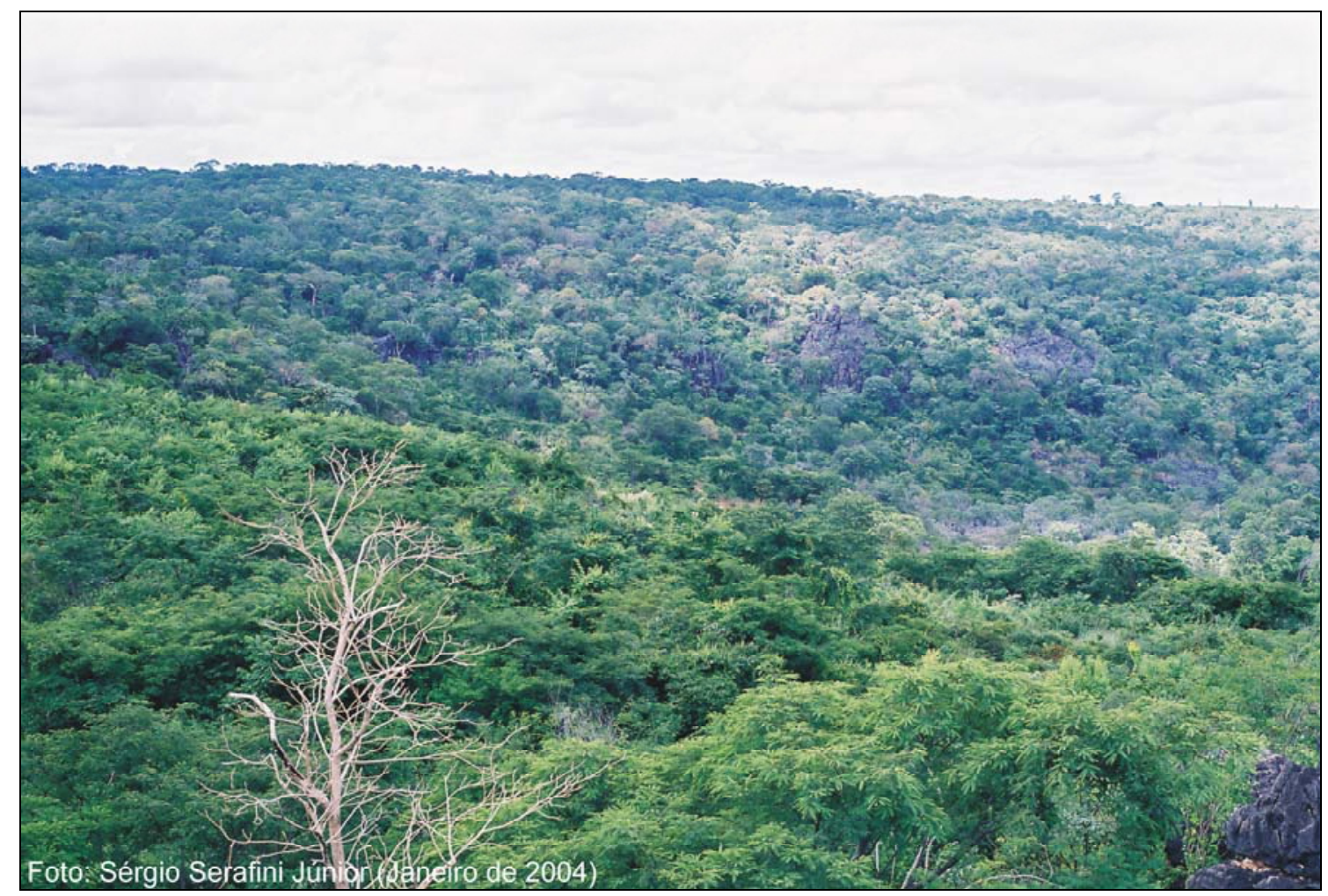

FIGURA 16: Trecho da área de estudo ocupada pela Formação Florestal.

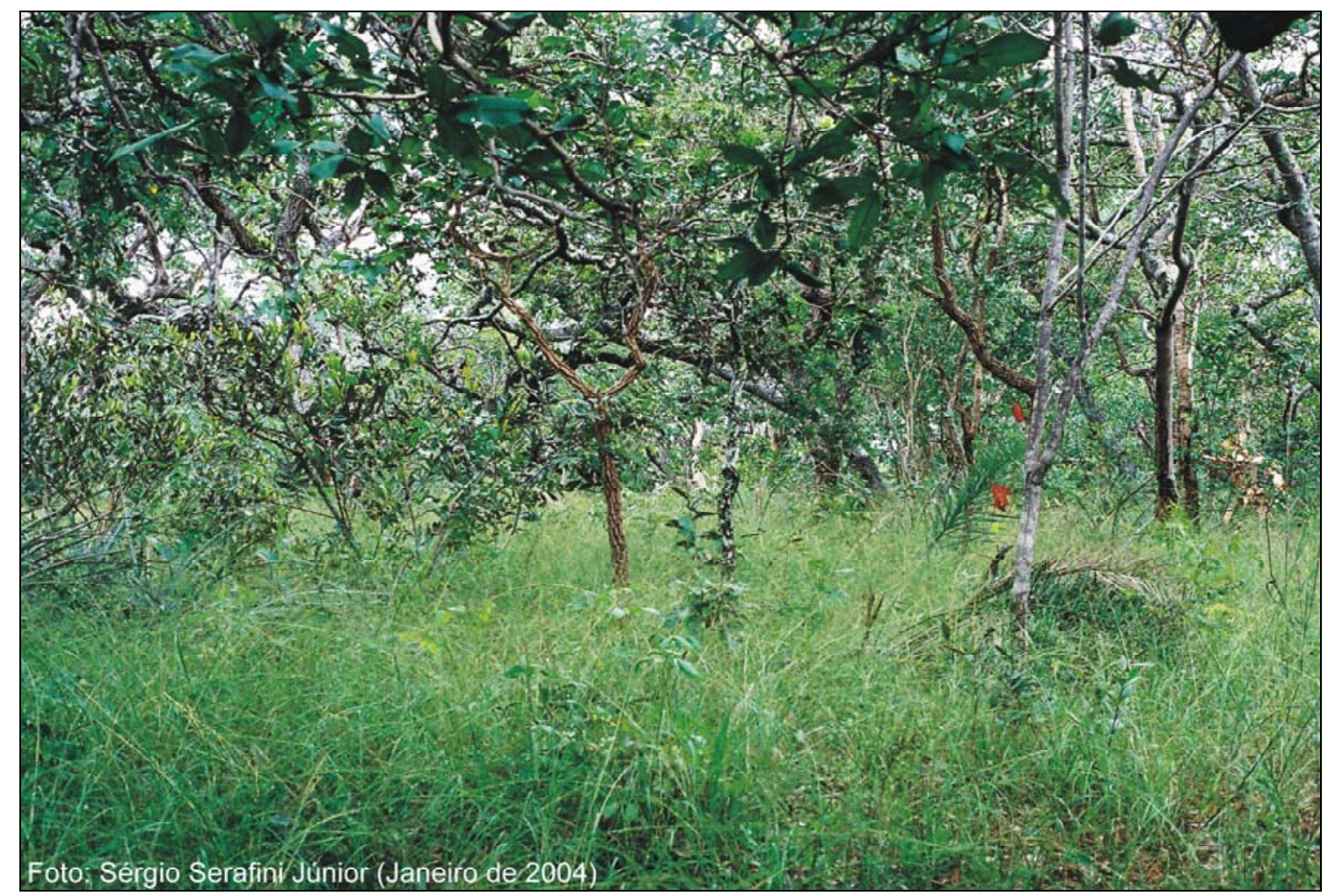

FIGURA 17: Trecho da área de estudo ocupada pela Formação Savânica. 


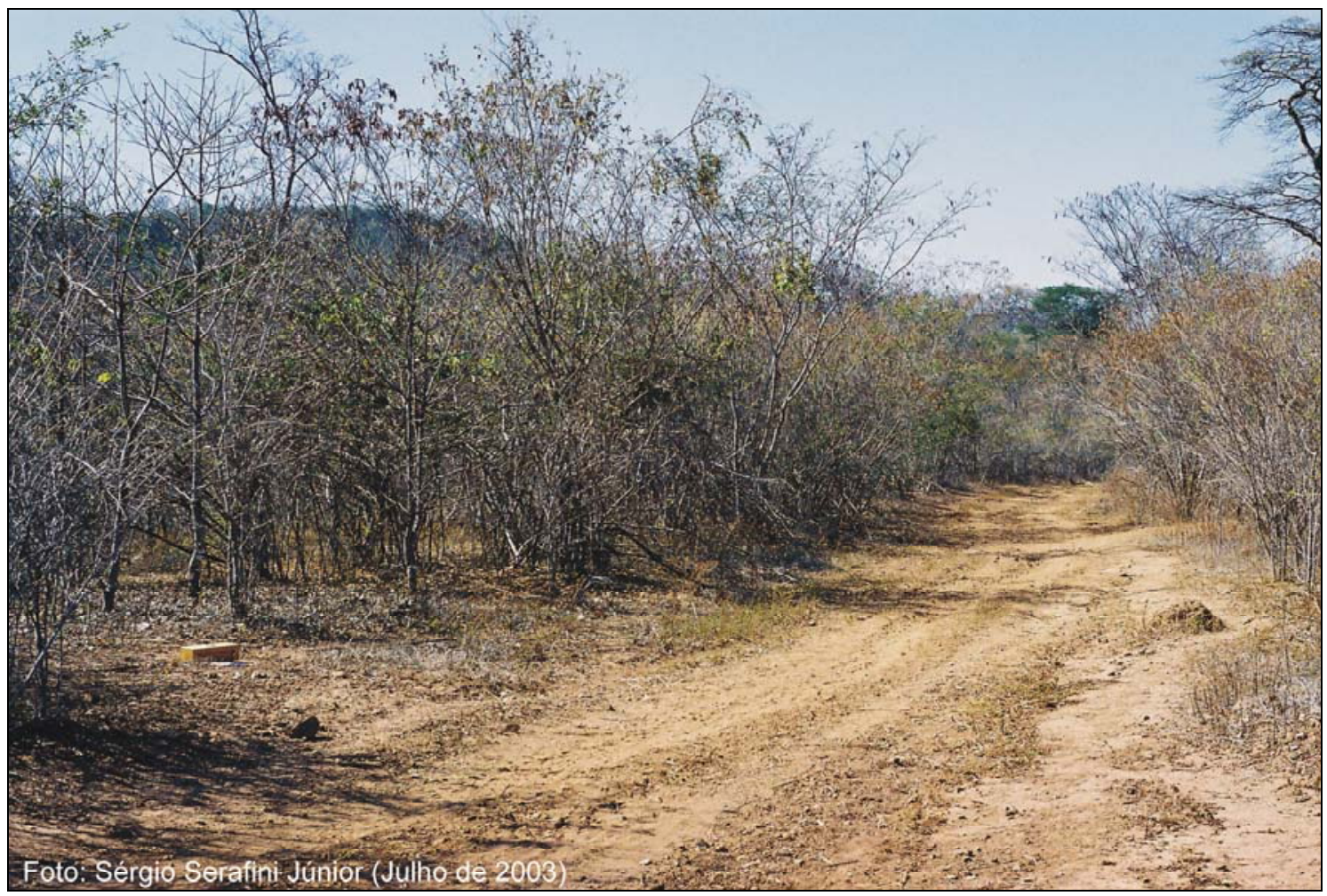

FIGURA 18: Trecho da área de estudo ocupada pela Formação Savânica Estépica.

\subsection{ASPECTOS SOBRE O USO E OCUPAÇÃO DO SOLO}

Os aspectos de uso e ocupação do solo apresentado a seguir foram baseados no relatório sobre este tema elaborado recentemente (2004) para compor o Plano de Manejo do Parque Nacional Cavernas do Peruaçu e nas observações realizadas durante o período de trabalho de campo.

Cabe observar que o mapa referente a este parâmetro é o mesmo apresentado na a caracterização da vegetação (FIGURA 15: Formações vegetais predominantes no Parque Nacional Cavernas do Peruaçu)

A região norte de Minas Gerais caracteriza-se pela predominância de atividades econômica ligadas à agricultura, onde são encontradas grandes propriedades rurais voltadas preferencialmente para a produção pecuária de corte, além de atividades complementares associadas ao extrativismo e pesqueiro mais freqüentes nas pequenas propriedades de produtores rurais que, notoriamente, são a maioria. Em virtude dessa economia majoritária de pequenos produtores rurais a representatividade econômica da região norte de Minas é incipiente. 
Observando as formas de uso e os padrões de ocupação do solo predominantes na área de estudo e seu entorno, constata-se que as características dos terrenos quaternários da depressão do rio São Francisco foram favoráveis à sua exploração econômica rural, onde são encontradas vastas extensões de terras ocupadas por produção pecuária desenvolvida por poucas grandes propriedades.

Contrariamente a estas grandes propriedades que representam um número pequeno, são numerosas as comunidades agrícolas e pequenas propriedades ali encontradas que estão distribuídas entre os três municípios.

$\mathrm{Na}$ porção de montante do Parque Nacional Cavernas do Peruaçu, as atividades são praticamente agrícolas, sediadas pelo Distrito de Várzea Grande (Município de Itacarambi). São propriedades pequenas que vivem predominantemente do que plantam e criam, com exceção das cooperativas organizadas, concentradas na farinha de mandioca, cachaça e rapadura.

As lavouras mais freqüentes são sempre de milho, de feijão e de mandioca, além da criação de víveres (galinhas, porcos e gado bovino). Culturalmente, tanto o grande ou o pequeno proprietário rural ainda se utilizam da queimada para limpeza dos seus terrenos, comprometendo seriamente a manutenção de ambientes naturais.

O histórico de ocupação da região e o quadro atual de uso e ocupação do solo, associado às atividades agropastoris revelam o alto índice de desmatamento com a freqüente retirada de madeira de lei, principalmente na depressão do rio São Francisco que já apresenta um elevado grau de alteração dos seus ambientes naturais que, hoje se encontram isolados em pequenas manchas.

Prática comum na região, devido à sequidão dos terrenos, é a irrigação por meio de pivôs centrais que promovem um grande desperdício de água, ao lançar uma quantidade superior àquela necessitada pela planta e que será evaporada posteriormente. Esta prática já foi realizada inclusive no alto Peruaçu (atualmente desativada).

A expansão das atividades antrópicas vem exercendo forte pressão sobre as áreas ocupadas por cobertura vegetal, impondo um recuo gradativo das faixas de contato com áreas de pastagem que se espalham sobre aqueles ambientes antes ocupados pelas Formações Savânica, Florestal e Savânica Estépica 
configurando-se, atualmente, como bordas residuais do processo de ocupação a partir das margens do São Francisco.

A distribuição da Formação Savânica na área de estudo, estende-se para oeste da área mapeada, praticamente acompanhando a montante o curso do rio Peruaçu que apresenta em suas margens extensas áreas ocupadas por atividades humanas.

$\mathrm{Na}$ porção norte, mais especificamente, as áreas ocupadas pela Formação Savânica encontra-se mais isolada em manchas, bordejada pela Formação Florestal que predomina dentro da área de estudo.

Ainda na porção norte, mas fora dos limites do Parque Nacional Cavernas do Peruaçu, podem ser observadas as pequenas manchas da Formação Savânica indicando um processo gradual de modificação daquele ambiente, associado com a presença humana vinculada à exploração predatória da madeira.

Nesta porção, a fiscalização é quase ausente, além de ser agravada pela proximidade da reserva indígena dos Xacriabás que legalmente pode fazer uso das matas para sobrevivência, mas segundo relatos obtidos nos caminhamentos de campo, vem comercializando a madeira retirada.

Em relação à Formação Florestal identificada na área de estudo e seu entorno, esta predomina dentro dos limites do Parque Nacional Cavernas do Peruaçu que se estende no sentido norte - sul acompanhando a calha do rio São Francisco.

Associada aos solos identificados na área de estudo, a Formação Florestal distribui-se acompanhando o Compartimento Carstificado, originando uma cobertura pedológica de cambissolos que apresentam características pouco desenvolvidas vinculadas à litologia que o sustenta.

Devido a esse perfil pouco desenvolvido há restrições na capacidade de armazenamento de água e de nutrientes permitindo o desenvolvimento de espécies adaptadas (mata seca) através da perda foliar em relação ao tempo de estiagem que está relacionada com a profundidade do solo em que se desenvolve. 
Entremeando-se a vegetação da Formação Florestal, são encontradas áreas de solos exposto (áreas degradadas) apresentando elevado processo de ravinamento (Figura 19).

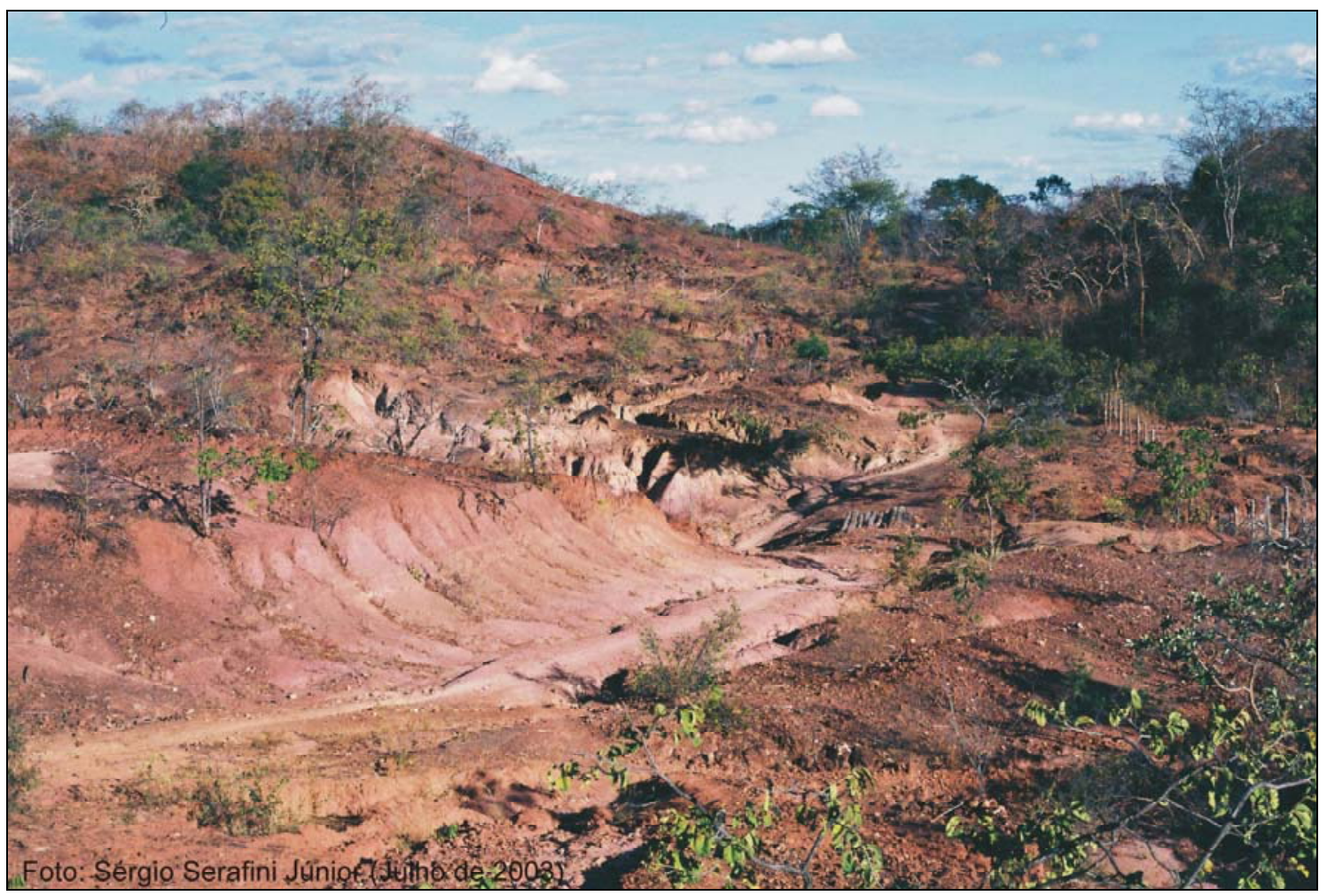

FIGURA 19: Área degradada presente no ambiente da Formação Florestal.

Como já fora observado, o Parque Nacional Cavernas do Peruaçu, encontra-se numa área de transição entre o Bioma Cerrado e o da Caatinga, entretanto nota-se que as áreas da vegetação indicativas da caatinga são pouco representativas dentro da área mapeada, limitando-se à depressão do rio São Francisco e lá encontrada em pequenas manchas isoladas entremeadas por outras onde predominam as atividades agrícolas representativas.

As características de uso e ocupação do solo apresentadas quando relacionadas à variação climática registrado nos ambientes antropogênicos, constata-se sua influência sobre a variação de temperatura e umidade relativa do ar, como será verificada mais adiante. 
DELIMITAÇÃO DE UNIDADES CLIMÁTICAS LOCAIS NO PARQUE NACIONAL CAVERNAS DO PERUAÇU

6. AS UNIDADES DE PAISAGEM DA ÁREA DE ESTUDO 
Neste trabalho as unidades de paisagem enquadradas na escala dos geossistemas identificadas foram definidas a partir das características dos compartimentos geomorfológicos por atuarem como agente de suporte das manifestações fisiográficas que envolvem as comunidades vegetais e humanas sobre da área de estudo.

Assim, com base nas características fisionômicas que apresentaram maior grau de homogeneidade, foram definidas três geossistemas. São eles:

- Geossistema da Depressão do Rio São Francisco (GDSF) - relevo plano, proximidade do o rio São Francisco e alto grau de antropização.

- Geossistema da Serras da Mãe Joana e do Cardoso de Minas (GSMC) - relevo residual cárstico formando as bordas do planalto ou patamares, posicionamento de vertentes variado; vegetação de porte arbórea perenifólia, semidecídua e hiperxerófila, proximidade com a depressão e do rio São Francisco.

- Geossistema do Planalto do Rio São Francisco (GPSF) - relevo plano, distanciamento do rio São Francisco, extensas áreas com vegetação predominante de cerrado / mata seca e uso do solo voltado para atividades pastoril.

Na Figura 20 que segue, são apresentadas as delimitações das unidades geossistêmica sobre o Parque Nacional Cavernas do Peruaçu, seguida pela Figura 21, onde são mostrados em fotos, os ambientes representativos destas unidades de paisagens dentro do Parque Nacional Cavernas do Peruaçu. 


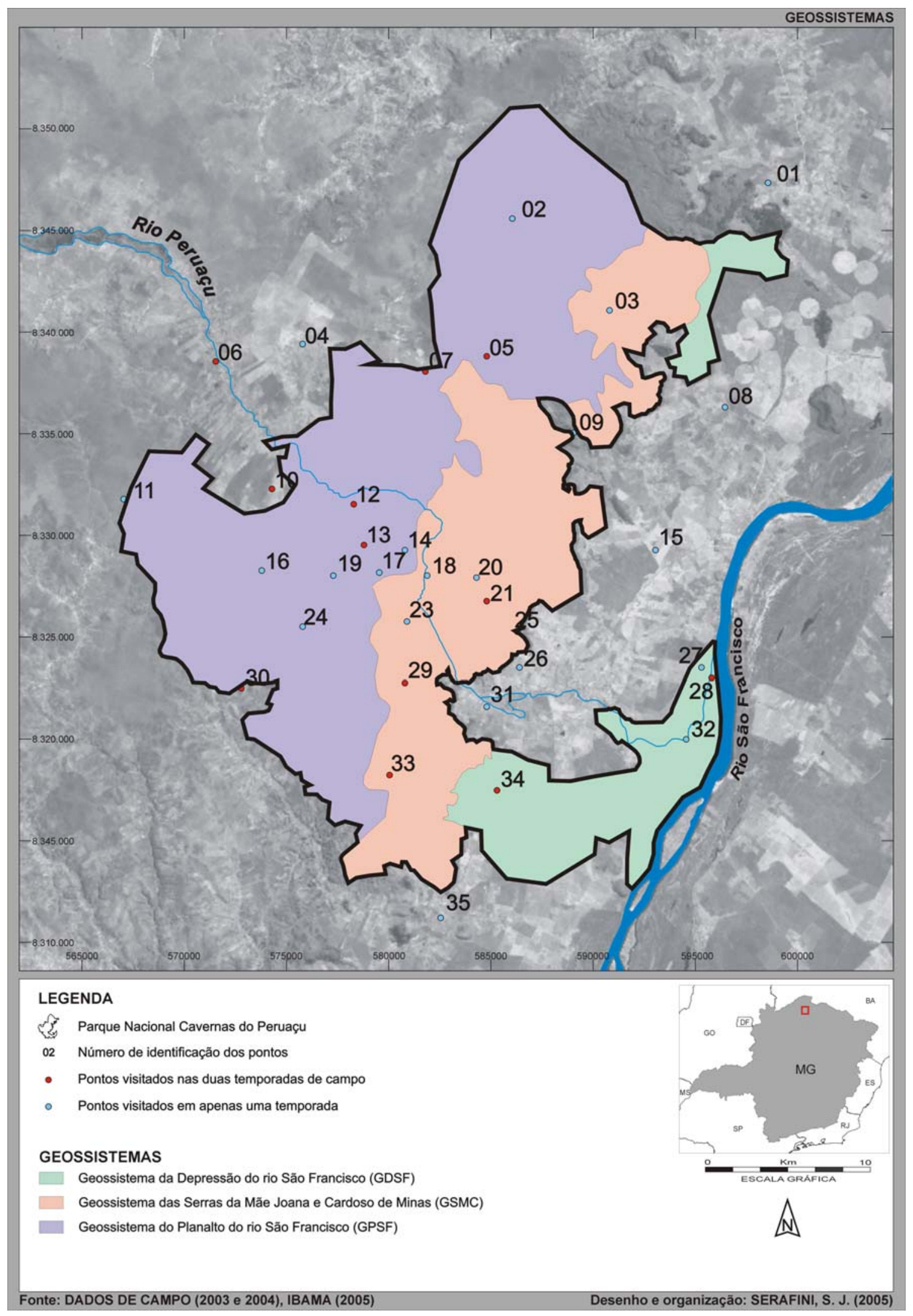

FIGURA 20: Delimitação dos geossistemas no Parque Nacional Cavernas do Peruaçu. 

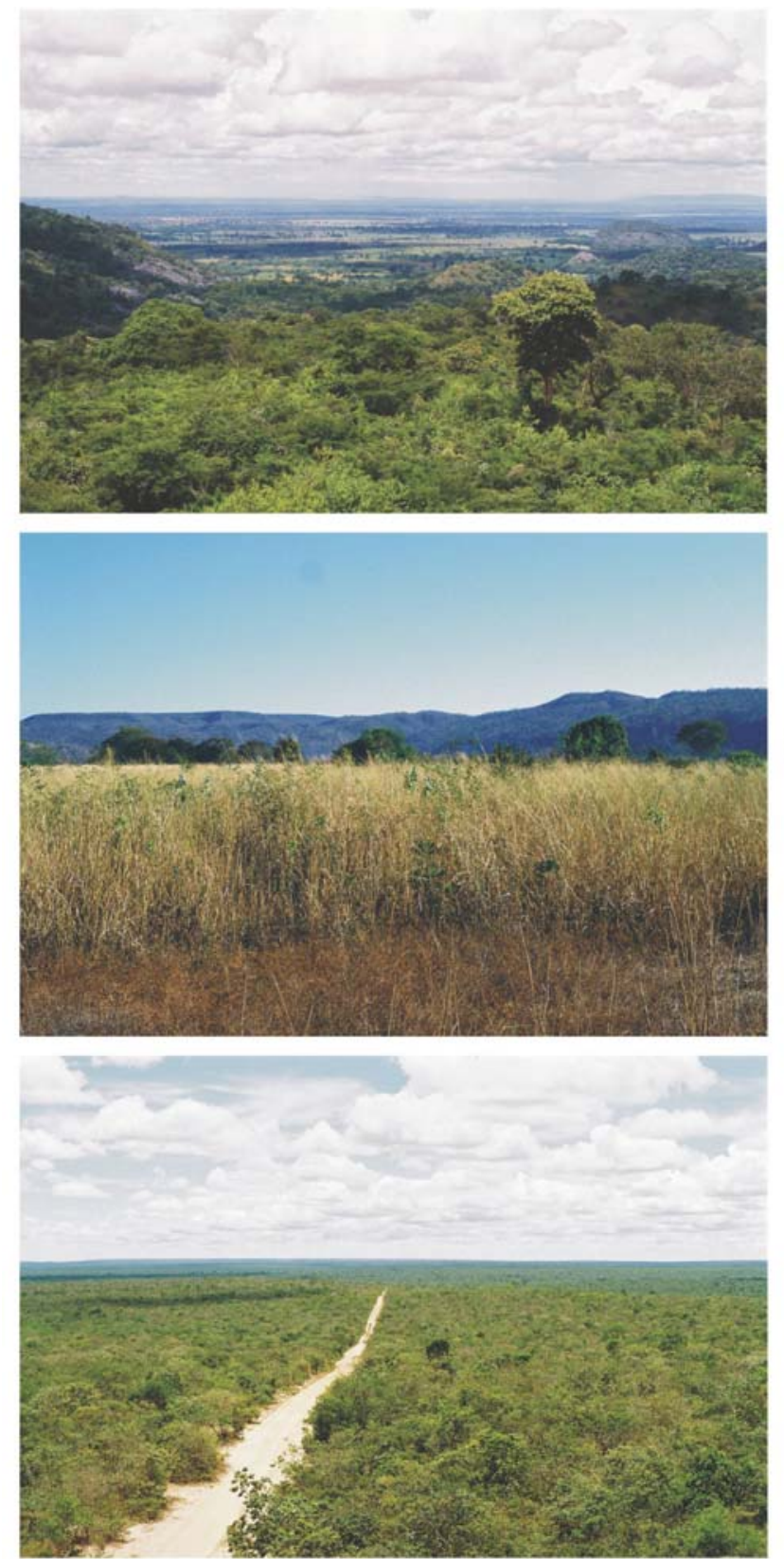

Fotos: Sérgio Serafini Júnior (Julho de 2003 e Janeiro de 2004)
Vista geral do Geossistema da Depressão do Rio São Francisco (GDSF), apresentando topografia plana e áreas ocupadas por pastagem (verde claro).

Vista geral do Geossistema das Serras da Mãe Joana e do Cardoso de Minas (GSMC) posicionada no segundo plano da imagem, ocupada por floresta estacional.

Vista geral do Geossistema do Planalto do Rio São Francisco (GPSF), onde predomina a formação savânica (cerrado).

FIGURA 21: Vista geral das unidades geossistêmicas identificadas no Parque Nacional Cavernas do Peruaçu.

Dentro destas, estão associadas as informações sobre os aspectos geomorfológicos na condição de suporte físico, sobre o qual foram considerados os elementos fitológicos e da ação antrópica numa escala de análise mais detalhada que se enquadra na escala das geofácies representadas pelas formações vegetais e ambientes antropogênicos, distintamente. 
Com base no sistema taxonômico de BERTRAND (op. cit., 1971) as geofácies, são os resultados dos estágios de evolução do primeiro nível taxonômico dos geossistemas, formando unidades fisionômicas que se unem numa mesma família geográfica, representando "uma pequena malha na cadeia das paisagens que se sucedem no tempo e no espaço no interior de um mesmo geossistema." (P. 17).

Em relação às geofácies identificadas, estas foram definidas com a seguinte nomenclatura e apresentadas na Figura 22:

- Geofácie da Formação Florestal (GfFF);

- Geofácie da Formação Savânica (GfFS);

- Geofácie da Formação Savânica Estépica (GfSE); e,

- Geofácie do Ambiente Antropogênico (GfAA).

Considerando a nomenclatura definida para cada um dos níveis, foi possível estabelecer relações diretas entre eles que se agrupam segundo o critério de homogeneidade e distribuídas como mostra o Quadro 03.

QUADRO 03: Taxonomia estabelecida para as unidades de paisagem definidas como geofácies.

\begin{tabular}{|c|c|}
\hline GEOSSISTEMA & GEOFÁCIE \\
\hline \multirow{4}{*}{ DEPRESSÃO DO RIO SÃO FRANCISCO } & FORMAÇÃO FLORESTAL \\
\hline & FORMAÇÃO SAVÂNICA \\
\hline & FORMAÇÃO SAVÂNICA ESTÉPICA \\
\hline & AMBIENTE ANTROPOGÊNICO \\
\hline \multirow{4}{*}{$\begin{array}{l}\text { SERRAS DA MÃE JOANA E DO CARDOSO DE } \\
\text { MINAS }\end{array}$} & FORMAÇÃO FLORESTAL \\
\hline & FORMAÇÃO SAVÂNICA \\
\hline & FORMAÇÃO SAVÂNICA ESTÉPICA \\
\hline & AMBIENTE ANTROPOGÊNICO \\
\hline \multirow{4}{*}{ PLANALTO DO RIO SÃO FRANCISCO } & FORMAÇÃO FLORESTAL \\
\hline & FORMAÇÃO SAVÂNICA \\
\hline & FORMAÇÃO SAVÂNICA ESTÉPICA \\
\hline & AMBIENTE ANTROPOGÊNICO \\
\hline
\end{tabular}

Fonte: Dados registrados em campo (julho de 2003 e janeiro de 2004).

Organização: Sérgio Serafini Júnior 


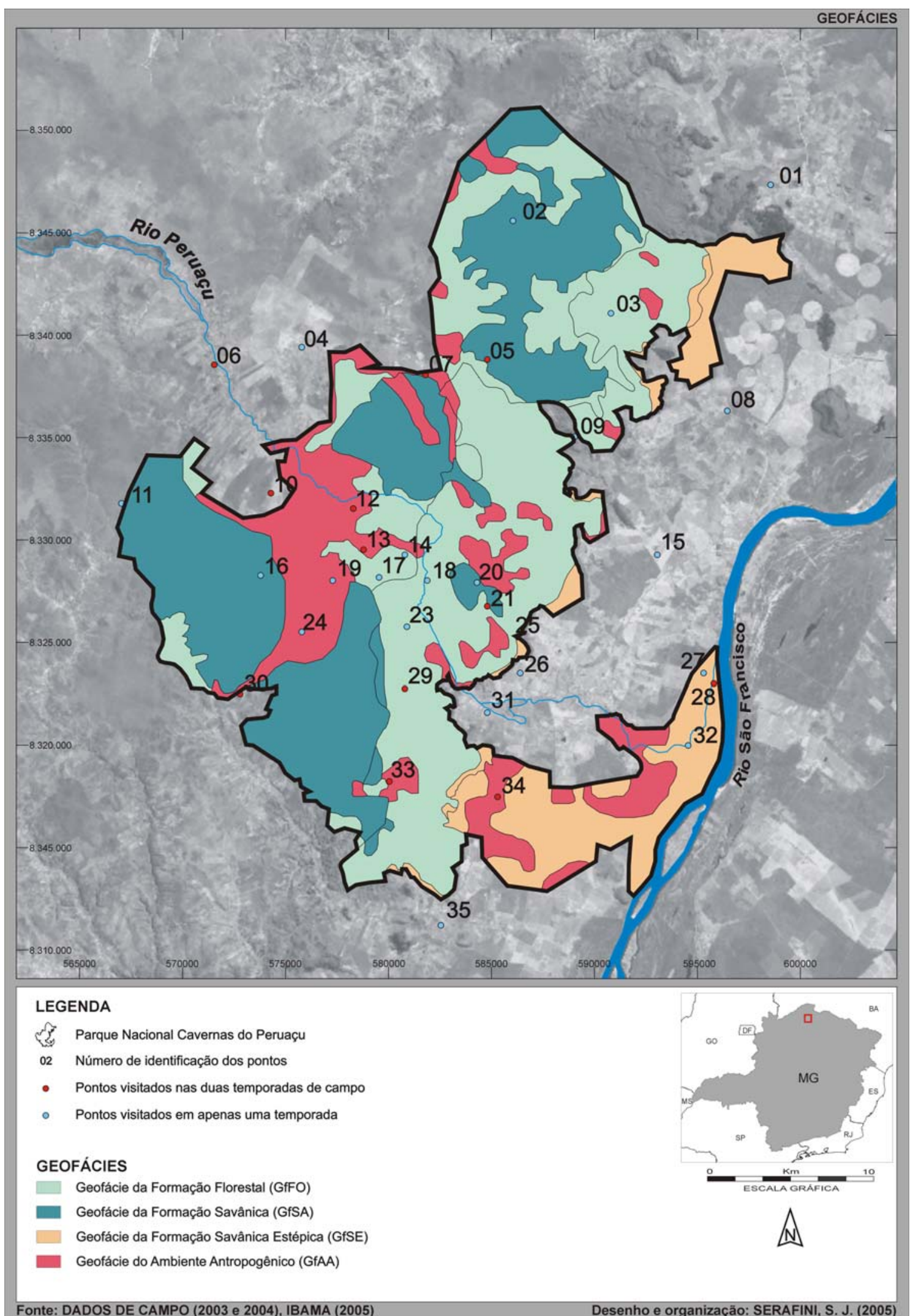

FIGURA 22: Delimitação das geofácies no Parque Nacional Cavernas do Peruaçu. 
DELIMITAÇÃO DE UNIDADES CLIMÁTICAS LOCAIS NO PARQUE NACIONAL CAVERNAS DO PERUAÇU (VERSÃO REVISADA)

7. O CLIMA DE MINAS GERAIS 
O mecanismo de circulação atmosférica influencia as características climáticas do território brasileiro que se estende da latitude de $5^{\circ} 16^{\prime}$ (Norte) a $33^{\circ} 45^{\prime}$ (Sul). A faixa entre a Linha do Equador e o Trópico de Capricórnio, que sinaliza o limite meridional da declinação anual do sol, marca as características de tropicalidade que se manifestam em quase todos os seus espaços, onde se formam diferentes zonas climáticas que estão condicionadas, sobretudo, pelas latitudes que determinam a distribuição diferenciada da energia solar sobre a superfície da Terra condicionando a quantidade de energia solar recebida ocasionando as estações.

Neste contexto da formação de zonas climáticas segundo a faixas de latitude, segundo CONTI (Apud. ROSS, 1997), no Brasil existem três principais domínios climáticos (equatorial, tropical e subtropical) que são subdivididos por seis tipos de clima, sendo eles:

- Clima equatorial úmido;

- Equatorial semi-úmido;

- Semi-árido;

- Subtropical; e

- Tropical de altitude; e,

- Tropical (estes dois últimos predominantes no Estado de Minas Gerais).

O domínio tropical (climas tropical e tropical de altitude) abrange toda a porção oriental e meridional da região Centro-Oeste, praticamente toda a região Nordeste e Sudeste, incluindo o Estado de Minas Gerais, apresentando variações climáticas conforme a atuação dos diferentes sistemas atmosféricos, de fatores geográficos e da própria sazonalidade.

Praticamente, no domínio tropical registram-se temperaturas médias acima de $18^{\circ} \mathrm{C}$, havendo uma nítida alternância entre a estação chuvosa e estação seca.

Já para o IBGE (2004) o clima de Minas Gerais pertence ao clima zonal denominado de Tropical Brasil Central (Figura 23), dentro do qual a área de estudo está inserida nos climas quentes (árido e semi-úmido), apresentando temperaturas médias acima dos $18^{\circ}$ durante todo o ano, coincidindo com a divisão climática proposta por CONTI (op. cit., 1997) e com períodos de 
estiagem entre quatro a cinco meses no quente úmido e de seis meses no semi-árido, como pode ser observado na Figura 24.

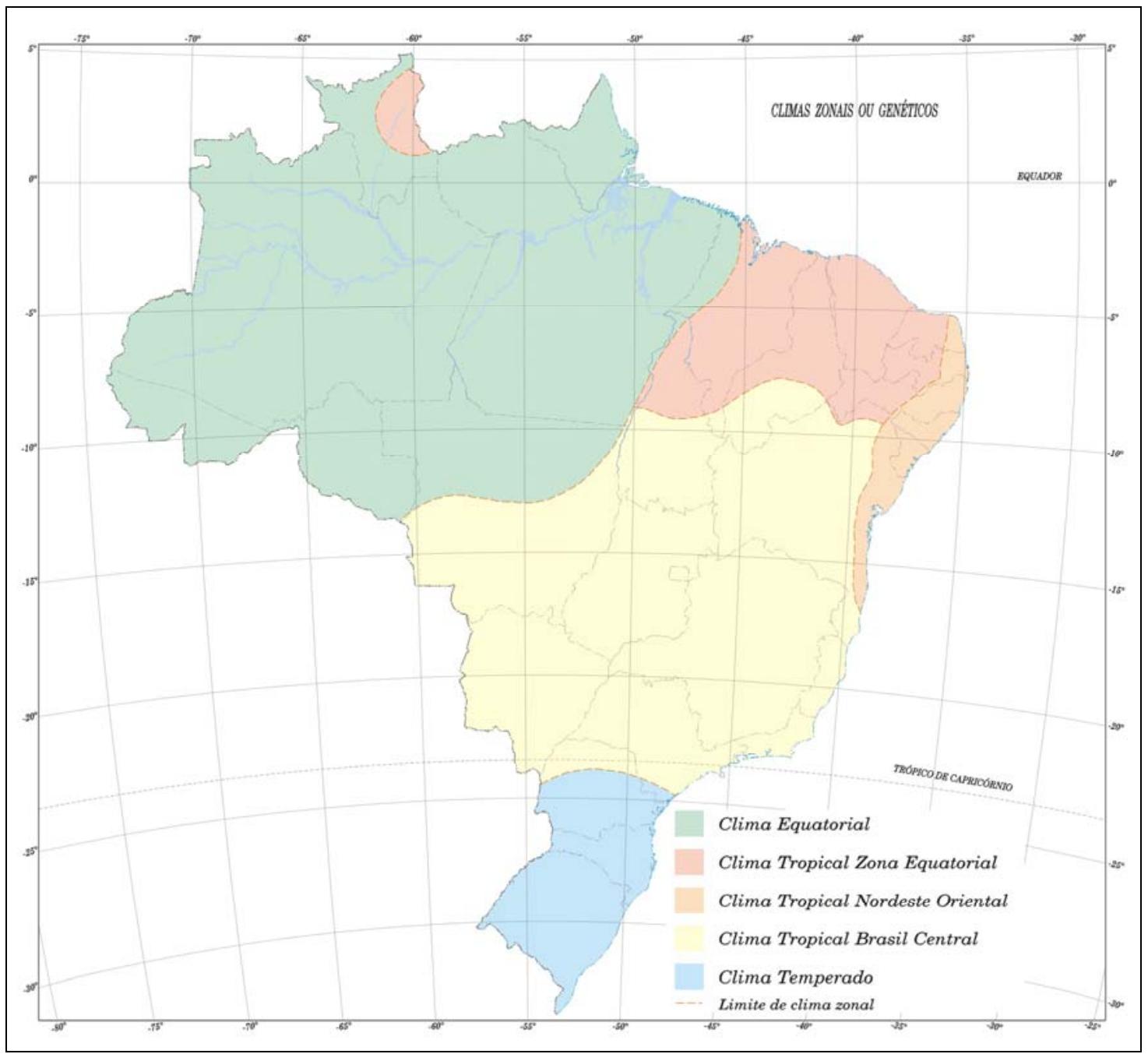

FIGURA 23: Os climas zonais do Brasil.

Fonte: IBGE (2003). 


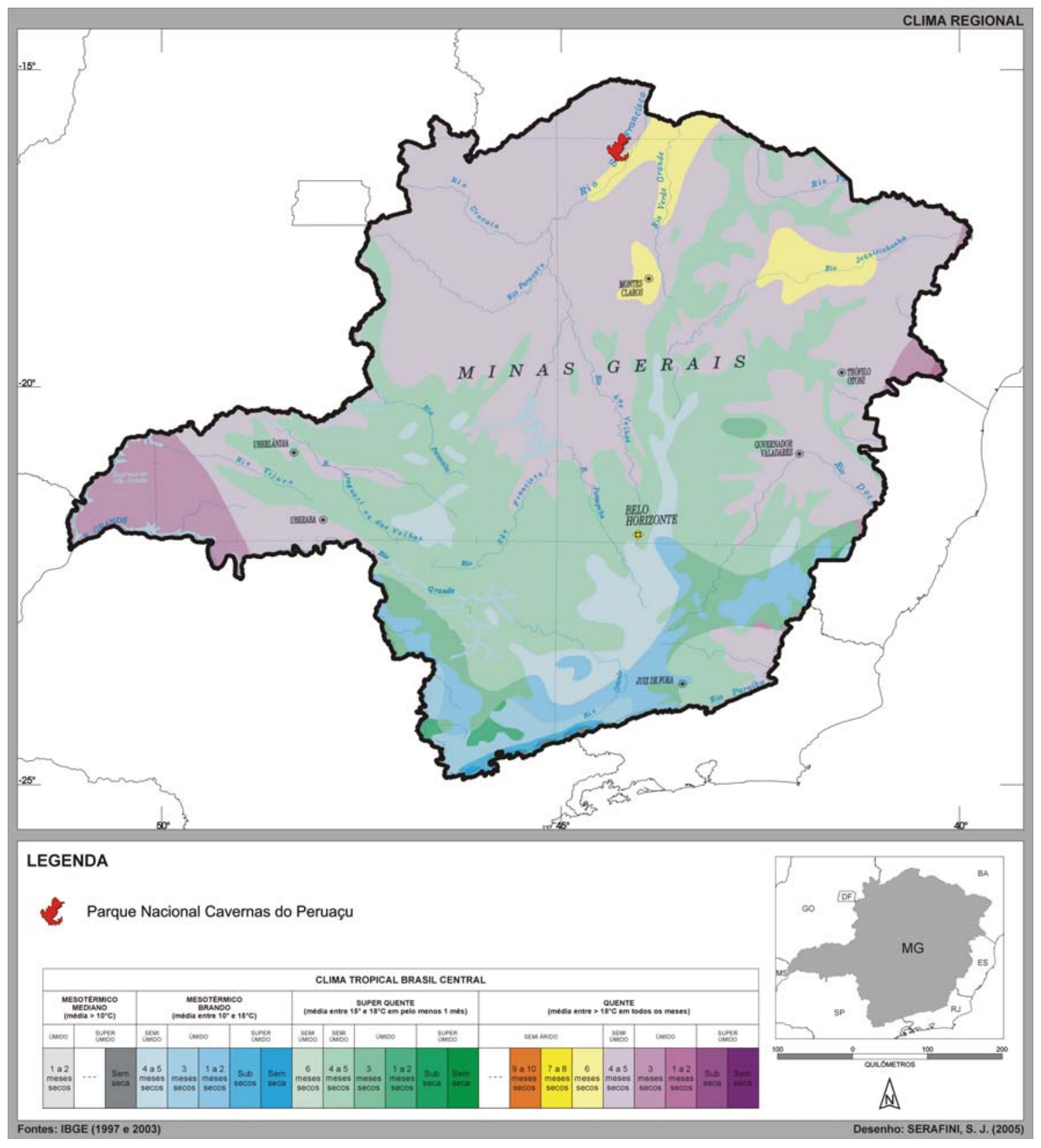

FIGURA 24: Climas regionais do Estado de Minas Gerais, segundo o IBGE (2005), com destaque para o Parque Nacional Cavernas do Peruaçu.

Assim, considerando a localização do Parque Nacional Cavernas do Peruaçu em relação aos climas regionais apontados pelo IBGE (op. cit., 2004) pode-se entender que esta Unidade de Conservação praticamente se encontra numa faixa de transição entre eles, influenciando, inclusive a composição da vegetação, como já foi observado. 


\section{A CARACTERIZAÇÃO CLIMÁTICA DA REGIÃO DE ESTUDO}




\subsection{A CIRCULAÇÃO REGIONAL DA ATMOSFERA}

Em linhas gerais, é a circulação atmosférica o principal mecanismo de influência das características climáticas do território brasileiro, produzindo tipos de tempo que determinam o comportamento dos atributos climáticos que se manifestam numa evolução rítmica e de caráter habitual.

$\mathrm{Na}$ escala continental sul americana a circulação atmosférica está condicionada à existência de centros de ação que se constituem como áreas ou regiões produtoras de sistemas atmosféricos que assumem diferentes características segundo sua área de origem e sua trajetória.

Os centros de ação atuantes na América do Sul são:

- Anticiclone migratório polar;

- Alta subtropical do atlântico sul;

- Depressão do chaco; e,

- Depressão da planície amazônica.

O anticiclone migratório polar é um centro de ação que está localizado no extremo sul América do Sul, portanto, mais fria, formando ali grandes massas de ar frio e seco que se deslocam para as baixas latitudes.

Seguindo para o norte, essa massa de ar frio depara-se com a Cordilheira dos Andes separando-se em duas menores, uma delas avançando sobre o território brasileiro, caracterizando-se como um sistema de alta pressão.

Associadas ao avanço dessa massa de ar frio para as baixas latitudes, tem-se a formação de frentes frias que se constituem extensas faixas de nebulosidade que progridem no formato de ondas no sentido SE - NE, por isso ser enquadrada como um tipo de perturbação denominada de "ondulatória" que são predominantes sobre as Regiões Sul, Sudeste e Nordeste do Brasil.

Enquanto no inverno, as frentes frias deslocam-se mais para o norte $\mathrm{e}$ nordeste, levando consigo temperaturas e umidades mais baixas, no verão, tendem a ficar estacionadas sobre uma determinada região, dando origem à Zona de Convergência do Atlântico Sul - ZCAS, sendo considerada como a maior responsável pelas chuvas de verão. 
As ZCAS são sistemas meteorológicos típicos de verão, caracterizado por uma banda de nuvens que produz chuva intensa, geralmente se estendendo do Brasil Central (Região Sudeste e/ou Centro-Oeste) até o Oceano Atlântico.

Em relação à alta sub-tropical do atlântico sul, este centro de ação localiza-se sobre o oceano Atlântico e responde pela formação dos sistemas atmosféricos carregado de umidade vinda do mar que tem influência pronunciada sobre o continente, principalmente na vertente atlântica.

$\mathrm{Na}$ maior parte do ano estes sistemas atmosféricos vindos do mar avançam sobre o continente em direção de Leste para Oeste e de Leste para Noroeste, favorecendo uma situação de estabilidade que é quebrada, no verão, devido ao aquecimento basal que origina células convectivas e precipitações locais no interior do continente e orográficas na vertente atlântica.

Em relação aos centros de ação da Depressão do Chaco e da Planície Amazônica, estes estão localizados sobre regiões de forte aquecimento sobre o continente intensificando as convecções no interior do continente e gerando. Por vezes, a convecção instalada na região centro-norte da América do Sul conecta-se com uma frente fria estacionada ou semi-estacionada provocando períodos com chuvas no sudeste do Brasil. No caso da região amazônica, não só responde pelo aquecimento, como também, pelo aumento da umidade e das precipitações.

A partir desse esboço da circulação atmosférica e, considerando sua importância na escala regional e, por conseguinte, na compreensão do clima local do Parque Nacional Cavernas do Peruaçu, serão apresentadas as características climáticas do Estado de Minas Gerais, tendo como componente principal a radiação solar.

\subsection{A RADIAÇÃO SOLAR}

De modo geral, a radiação solar, a circulação atmosférica e os tipos de tempos estão associados por meio de processos físicos e termodinâmicos, transferindo suas características para as camadas da atmosfera mais próximas à superfície, impondo um balanço de energia diferenciado que se reflete nas diferenças climáticas em todas as escalas de análise. 
A radiação solar constitui-se como um dos principais componentes dos eventos meteorológicos e variação climática em todos os níveis do sistema atmosférico devido ao aporte energético que chega à superfície em quantidades diferenciadas segundo os movimentos de rotação, translação, e obliqüidade do eixo fixo da Terra.

Enquanto no movimento de rotação é definida a quantidade de radiação solar ao longo das 24 horas (ciclo dia e noite), ao movimento de translação estão associadas às diferenças energéticas impostas pela posição que o planeta está ocupando na elíptica num determinado momento.

No solstício de verão para ambos os hemisférios (21/12 no Hemisfério Sul e 21/06 no Hemisfério Norte), a altura do sol sobre o horizonte do observador é mais elevada, proporcionando maior quantidade de radiação solar incidente sobre a superfície, potencializando assim, os processos físicos e termodinâmicos da atmosfera.

Além disso, devido à curvatura da Terra, a variação latitudinal dos hemisférios contribui para que ocorra um recebimento diferenciado de energia solar entre as altas e baixas latitudes e entre os solstícios de inverno e verão, como será visto a seguir.

A partir da latitude de cada estação meteorológica do INMET utilizada neste trabalho, foram estimados os valores de radiação solar incidente no topo da atmosfera.

Para o mês de julho, o valor médio de radiação solar para o Estado de Minas Gerais é de $26 \mathrm{MJ} / \mathrm{m}^{2}$, enquanto que para o mês de janeiro esse valor foi de 42 $\mathrm{MJ} / \mathrm{m}^{2}$, representando uma variação em torno dos $60 \%$.

Distribuindo os valores de radiação solar obtidos para cada estação meteorológica do INMET de Minas Gerais e Estados vizinhos, verifica-se que no mês de julho, a porção norte recebe uma radiação solar média estimada em torno dos $28 \mathrm{MJ} / \mathrm{m}^{2}$ próxima à latitude $15^{\circ} \mathrm{S}$, decrescendo nas latitudes mais altas de Minas Gerais $\left(25^{\circ} \mathrm{S}\right)$, onde a radiação média estimada foi de aproximadamente $24 \mathrm{MJ} / \mathrm{m}^{2}$, como pode ser observado na Figura 25.

Em janeiro a situação praticamente se inverte, pois as latitudes médias estão numa posição praticamente perpendicular aos raios solares, propiciando o 
aumento das temperaturas, da taxa de evaporação, da umidade do ar e da nebulosidade que, conseqüentemente proporciona a diminuição da insolação.

Considerando a distribuição dos valores médios de radiação solar sobre o Estado de Minas Gerais no mês de janeiro, pode ser observado que, contrariamente ao verificado em julho, a radiação solar aumenta proporcionalmente ao aumento da latitude, como mostra a Figura 26.

Por isso ao sul de Minas Gerais, os valores de radiação solar estimados ficam em torno dos $42 \mathrm{MJ} / \mathrm{m}^{2}$, enquanto que na porção norte esse valor fica em torno dos $41 \mathrm{MJ} / \mathrm{m}^{2}$, constatando uma amplitude bem menor daquela verificada em julho. 


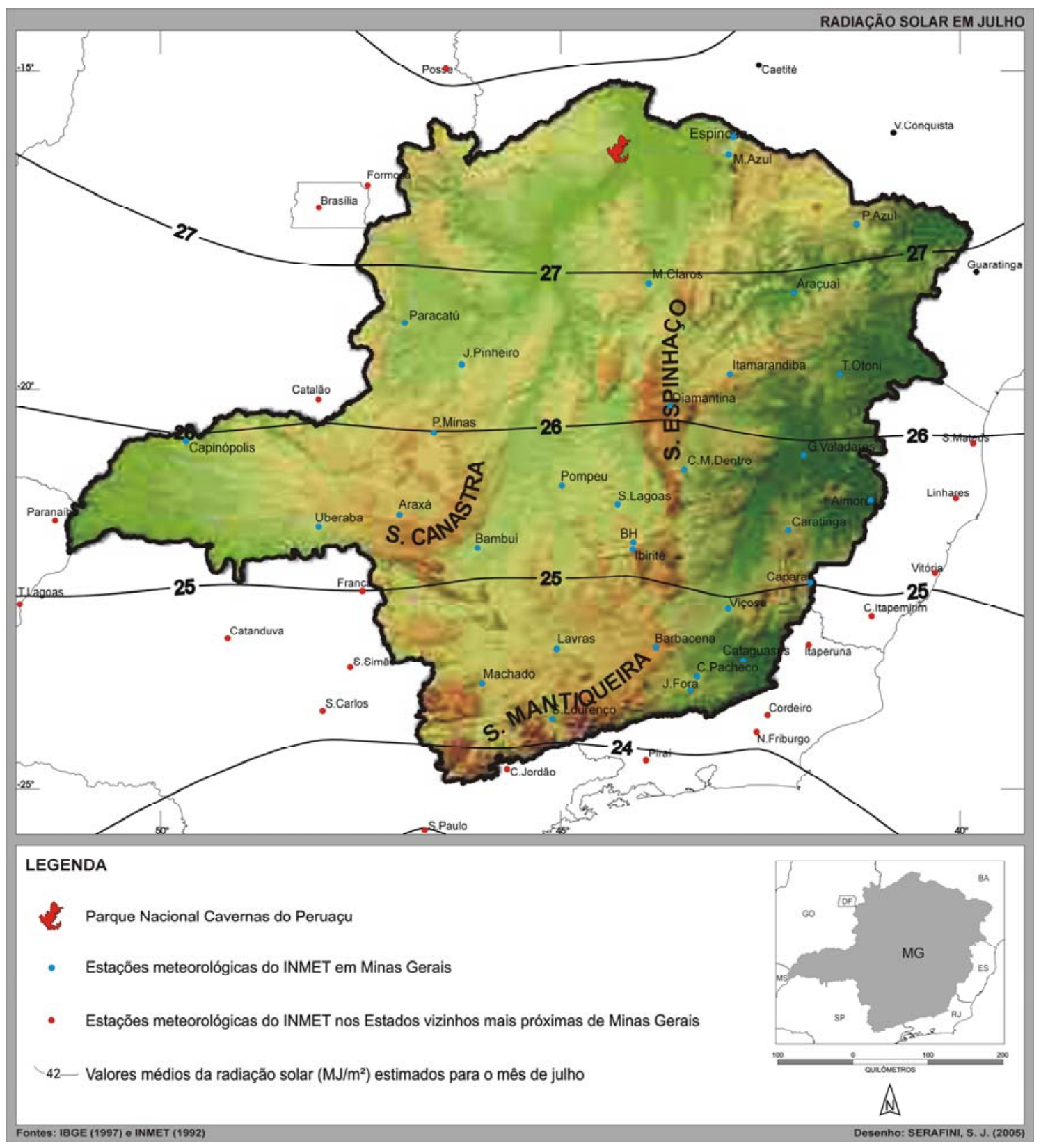

FIGURA 25: Radiação solar $\left(\mathrm{MJ} / \mathrm{m}^{2}\right)$ média estimada para o topo da atmosfera no mês de julho no Estado de Minas Gerais. 


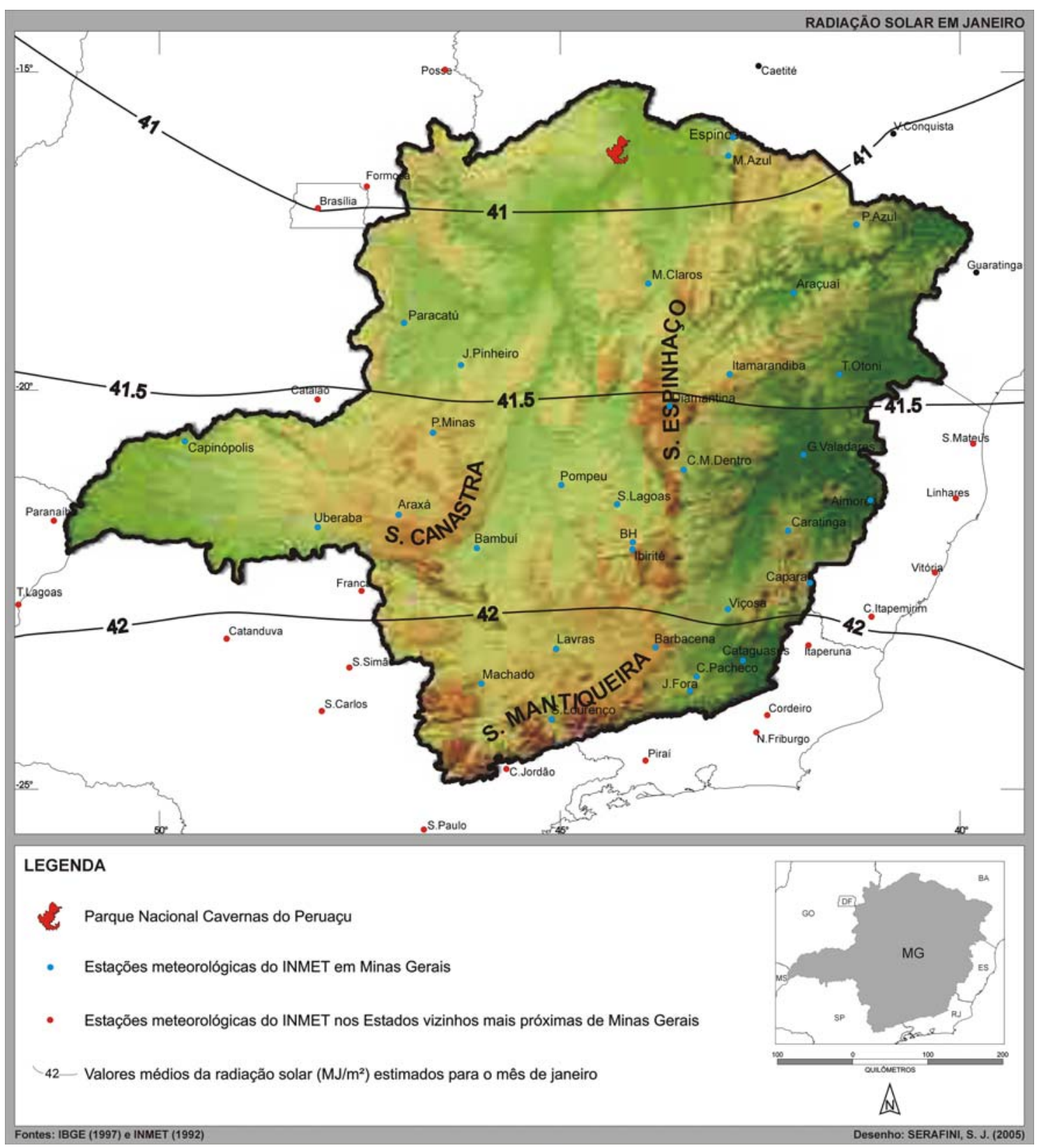

FIGURA 26: Radiação solar $\left(\mathrm{MJ} / \mathrm{m}^{2}\right)$ média estimada para o topo da atmosfera no mês de janeiro no Estado de Minas Gerais.

Assim, considerando as estações de Monte Azul e Espinosa que se localizam na mesma faixa latitudinal da área de estudo, a radiação solar média incidente no topo da atmosfera estimada para o Parque Nacional Cavernas do Peruaçu para os meses de julho de 2003 e janeiro de 2004 ficou em torno dos 28 e 41 $\mathrm{MJ} / \mathrm{m}^{2}$, respectivamente; muito próximos dos valores médios estimados para todo o Estado (26 e $42 \mathrm{MJ} / \mathrm{m}^{2}$ em julho e janeiro, respectivamente), interferindo nos valores de temperatura para os mesmos períodos. 


\subsection{A TEMPERATURA DO AR}

A variação sazonal da temperatura é resultante, sobretudo, do volume de radiação solar recebida numa dada região fazendo com que no verão, os dias sejam mais longos, favorecendo a maior recepção de energia e no inverno, os dias sejam mais curtos e a conseqüente diminuição dessa energia.

$\mathrm{Na}$ situação de dias mais longos, conseqüentemente há uma taxa maior de evaporação com a intensificação de movimentos convectivos, propiciando os tipos de tempo com temperaturas mais elevadas, alta umidade relativa do ar, presença de nuvens do tipo cúmulo e cumuloninbus e precipitações intensas e de curta duração. Já no inverno, os dias são ensolarados, temperaturas baixas, céu com poucas nuvens.

Considerando os dados normais climatológicos entre 1961 e 1990 registrados nas 32 estações meteorológicas do INMET distribuídas no Estado de Minas Gerais, tem-se uma temperatura média de $21,3^{\circ} \mathrm{C}$, com média mínima de $18^{\circ} \mathrm{C}$ registrada na estação meteorológica de Barbacena (2115' S) e média máxima de $24,6^{\circ} \mathrm{C}$ na estação de Governador Valadares (18 $\left.51^{\prime} \mathrm{S}\right)$.

Sabendo que a variação latitudinal influencia na temperatura de uma dada região, a constatação de valores médios de todo o Estado de Minas Gerais4 colabora pouco para a compreensão real do comportamento térmico regional.

Além da relação direta com latitude, que impõe uma quantidade de radiação solar diferenciada para cada faixa ao longo do ano, a variação térmica entre as duas porções do Estado dá-se também pela influência de outros elementos que se encontram mais próximos da superfície que atuam como controles climáticos que são a topografia, vegetação e atividades antrópicas, entre outros.

Para conseguir uma aproximação mais fiel da variação climática regional do Estado de Minas Gerais foi necessária uma análise mais detalhada dos registros de temperatura obtidos para cada estação meteorológica, associados a sua posição latitudinal e sua variação mensal, na tentativa de se obter um

4 O Estado de Minas Gerais possui uma variação aproximada de $8^{\circ}$ de latitude (entre 14 e $23^{\circ}$ Sul, aproximadamente), 
quadro aproximado da variação climática predominante na porção norte de Minas Gerais onde está localizada a área de estudo.

Distribuída espacialmente (Figura 27), a temperatura média no Estado de Minas Gerais, apresenta-se mais elevada na porção nordeste norte e noroeste do Estado, onde foram registrados valores médios anuais superiores a $22^{\circ} \mathrm{C}$, enquanto que na porção central, sul e sudoeste, as temperaturas médias anuais registradas entre 1961 e 1990, há uma variação entre 20 e $22^{\circ} \mathrm{C}$.

Distribuídos ao longo de um ano, estes valores indicam uma variação sazonal bem marcada entre os meses de inverno e verão, registrando entre eles uma amplitude térmica anual de $5,4^{\circ} \mathrm{C}$ (mínima de $18^{\circ} \mathrm{C}$ e máxima de $23,4^{\circ} \mathrm{C}$ ), como pode ser observado no Gráfico 01 , coincidindo com os valores médios de temperatura apresentados nas divisões climáticas do Brasil propostas por CONTI (op. cit., 1997) e IBGE (op. cit., 2004), isto é, temperaturas médias acima de $18^{\circ} \mathrm{C}$

No período de verão (dezembro, janeiro, fevereiro e março), de um modo geral, as temperaturas são mais elevadas pela própria posição do Sol no Hemisfério Sul mais elevada sobre o horizonte, disponibilizando maior quantidade de radiação solar, aquecendo mais a atmosfera, aumentando a taxa de evaporação e a formação de grandes massas convectivas.

Observando a distribuição espacial das temperaturas no período quadrimestral de dezembro, janeiro, fevereiro e março, estas se apresentam bem distribuídas e todo o Estado, com temperaturas acima dos $23^{\circ} \mathrm{C}$ registradas no Triângulo Mineiro e toda a faixa setentrional do Estado. 


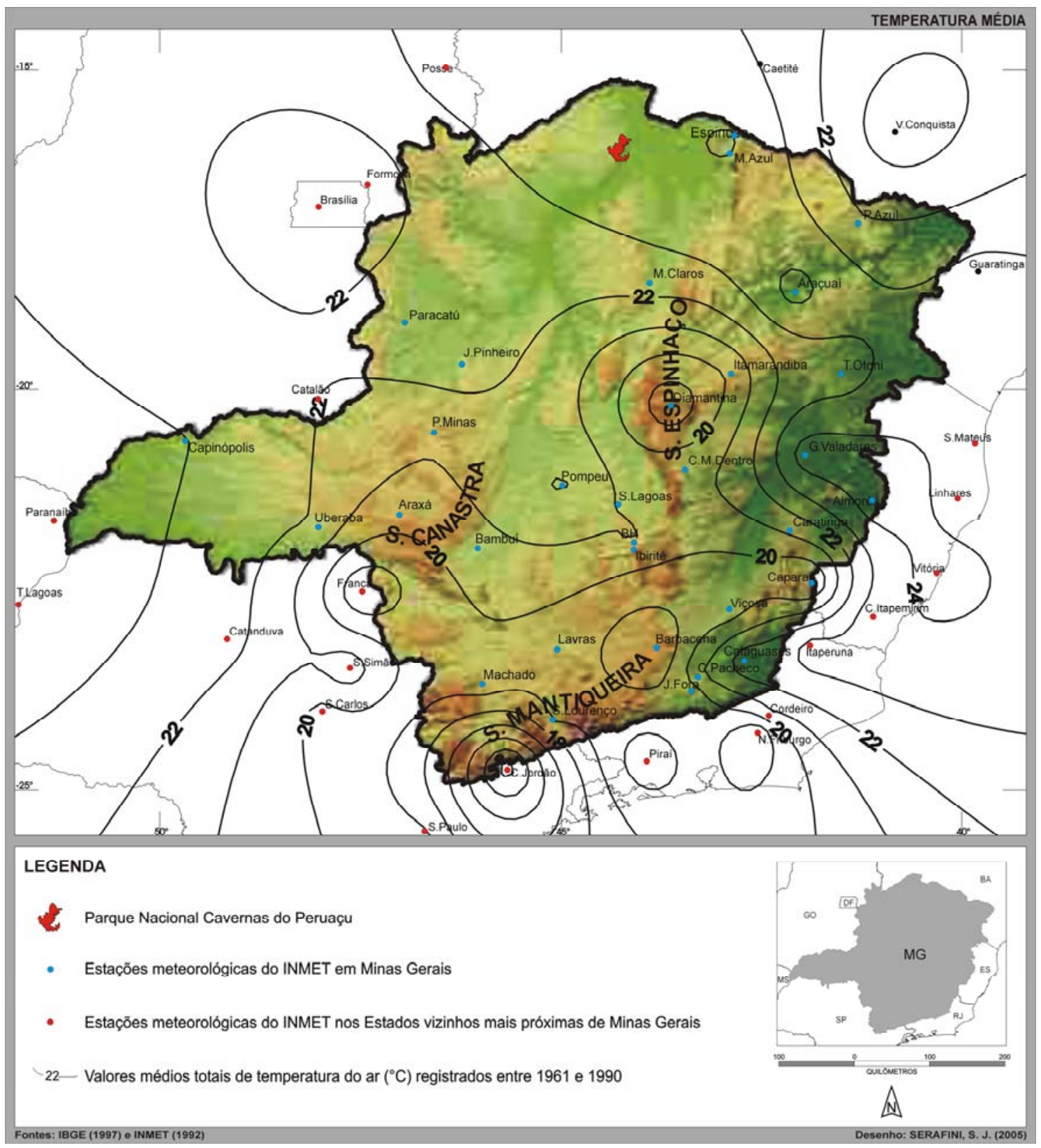

FIGURA 27: Temperatura média $\left({ }^{\circ} \mathrm{C}\right)$ no Estado de Minas Gerais, entre $1961 \mathrm{e}$ 1990.

Valores acima dos $23^{\circ} \mathrm{C}$ também são predominantes na faixa oriental do Estado próxima aos limites com os Estados do Espírito Santo, Rio de Janeiro e Bahia, onde se localiza o Parque Nacional Cavernas do Peruaçu e regiões climáticas semi-áridas. 
GRÁFICO 01: Distribuição mensal das temperaturas médias totais registradas no Estado de Minas Gerais.

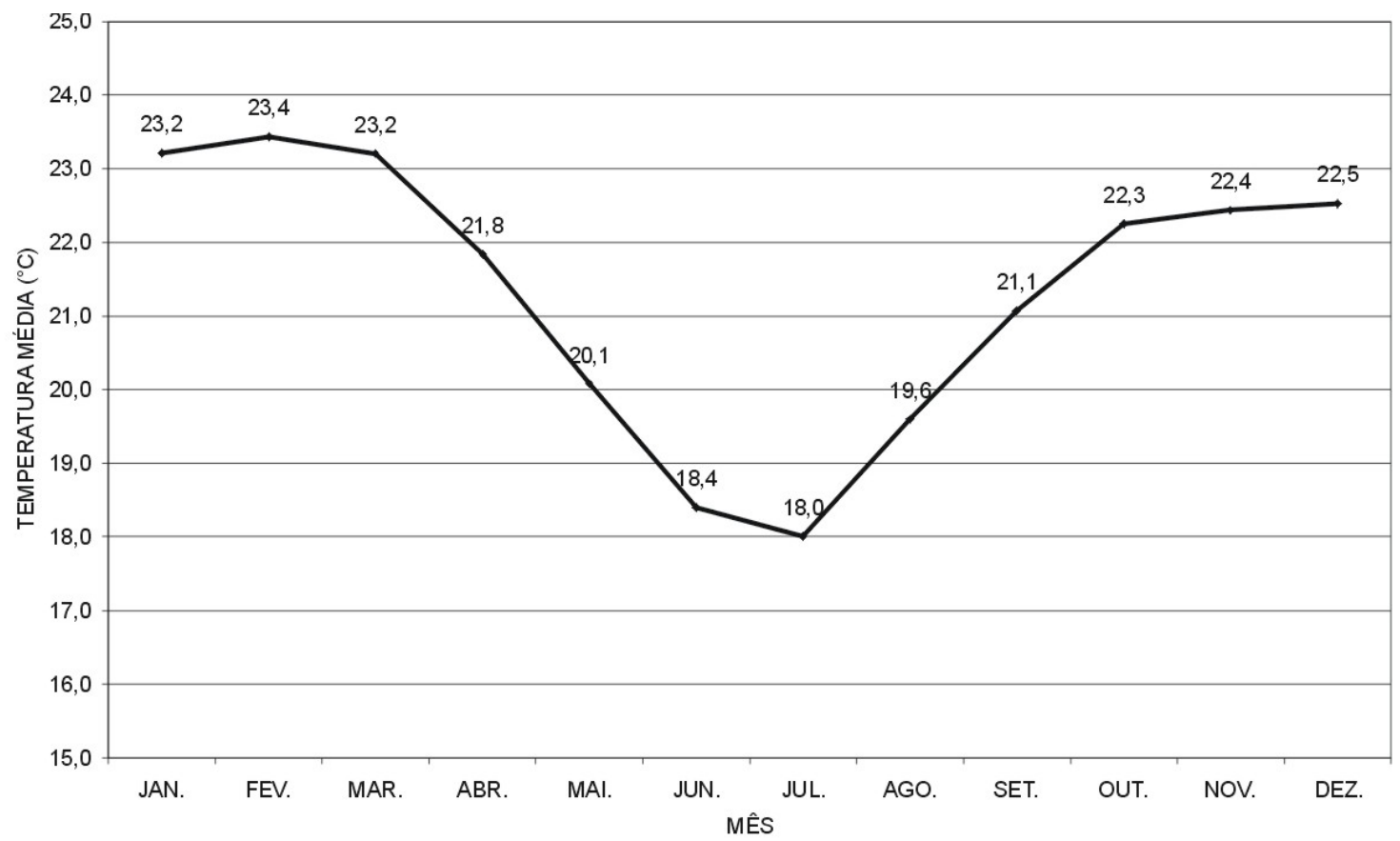

Fonte: INMET (1992).

Para o mesmo período quadrimestral, nas porções central, sul e sudoeste, as temperaturas predominantes variam entre 18 e $22^{\circ} \mathrm{C}$, aproximadamente, coincidindo com as regiões onde estão localizadas as Serras da Mantiqueira, Canastra e Espinhaço, como mostra a Figura 28.

Em relação ao período quadrimestral de junho, julho, agosto e setembro, as temperaturas médias variam entre 18 e $21^{\circ} \mathrm{C}$, aproximadamente, com uma amplitude térmica em torno dos de $8^{\circ} \mathrm{C}$.

A distribuição espacial das temperaturas médias desse período mostra que a porção centro sul como a região mais fria do Estado, principalmente, nas faixas próximas às Serras da Mantiqueira, localizada na porção extremo sul, fazendo limite interestadual com São Paulo. 


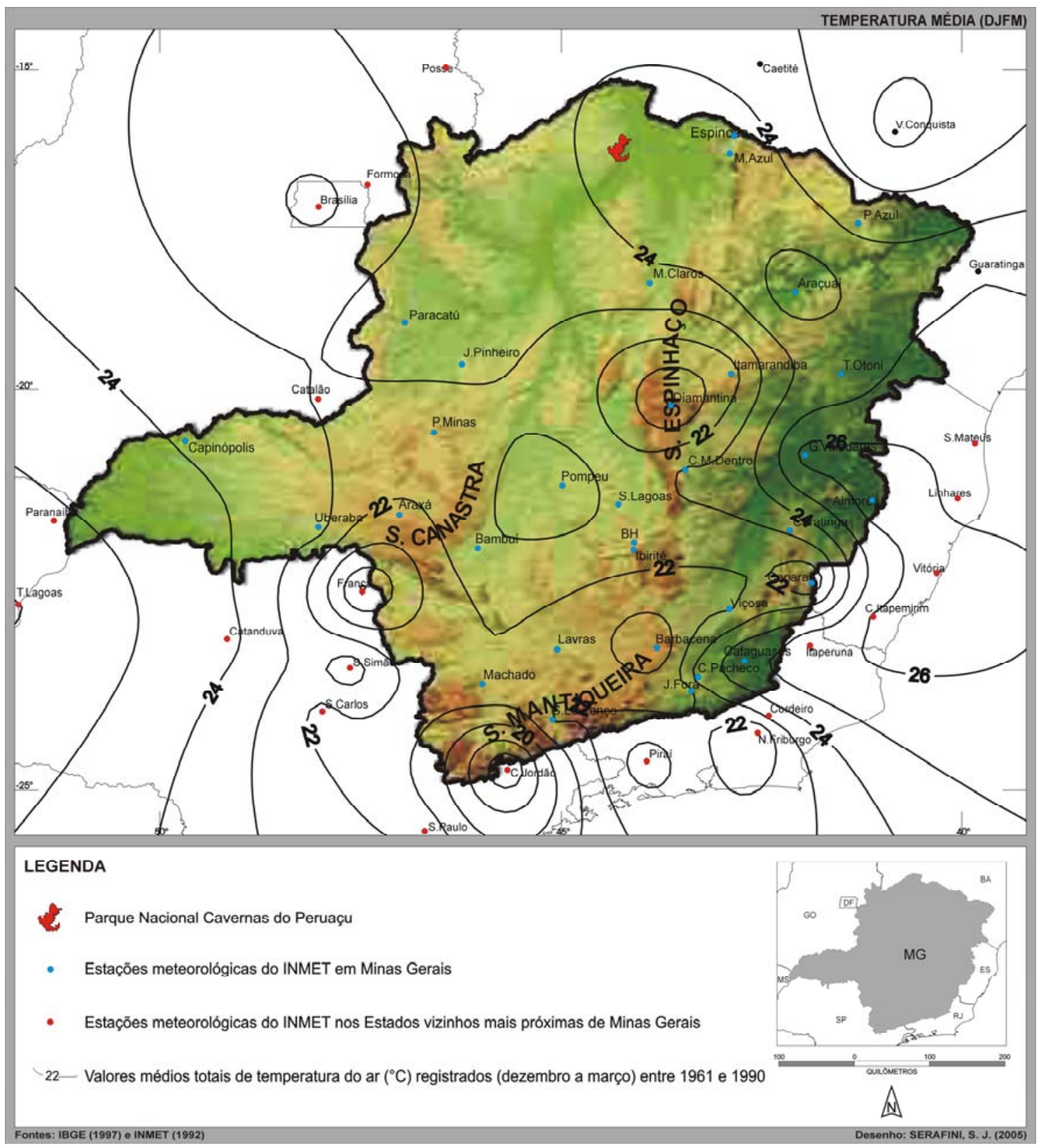

FIGURA 28: Temperatura média $\left({ }^{\circ} \mathrm{C}\right)$ no Estado de Minas Gerais, dos meses de dezembro, janeiro, fevereiro e março entre 1961 e 1990.

No período de inverno a posição do sol no Hemisfério Sul impõe um recebimento de radiação solar em menor quantidade que, associada com a própria curvatura do Planeta determina um menor aquecimento da superfície criando atmosfera mais fria e mais estável, favorável à penetração de massas de ar frias vindas das regiões das altas latitudes que avançam mais para norte sobre o continente passando sobre Minas Gerais.

De modo geral, a interferência dessa penetração de massas de ar frias mais para o norte pode ser notada através dos valores das temperaturas médias 
distribuídas sobre o Estado de Minas Gerais (Figura 29), mostrando toda a porção sul e sudeste com temperaturas mais baixas (abaixo dos $20^{\circ} \mathrm{C}$ ) coincidindo com o trajeto preferencial daquelas massas de ar frio.

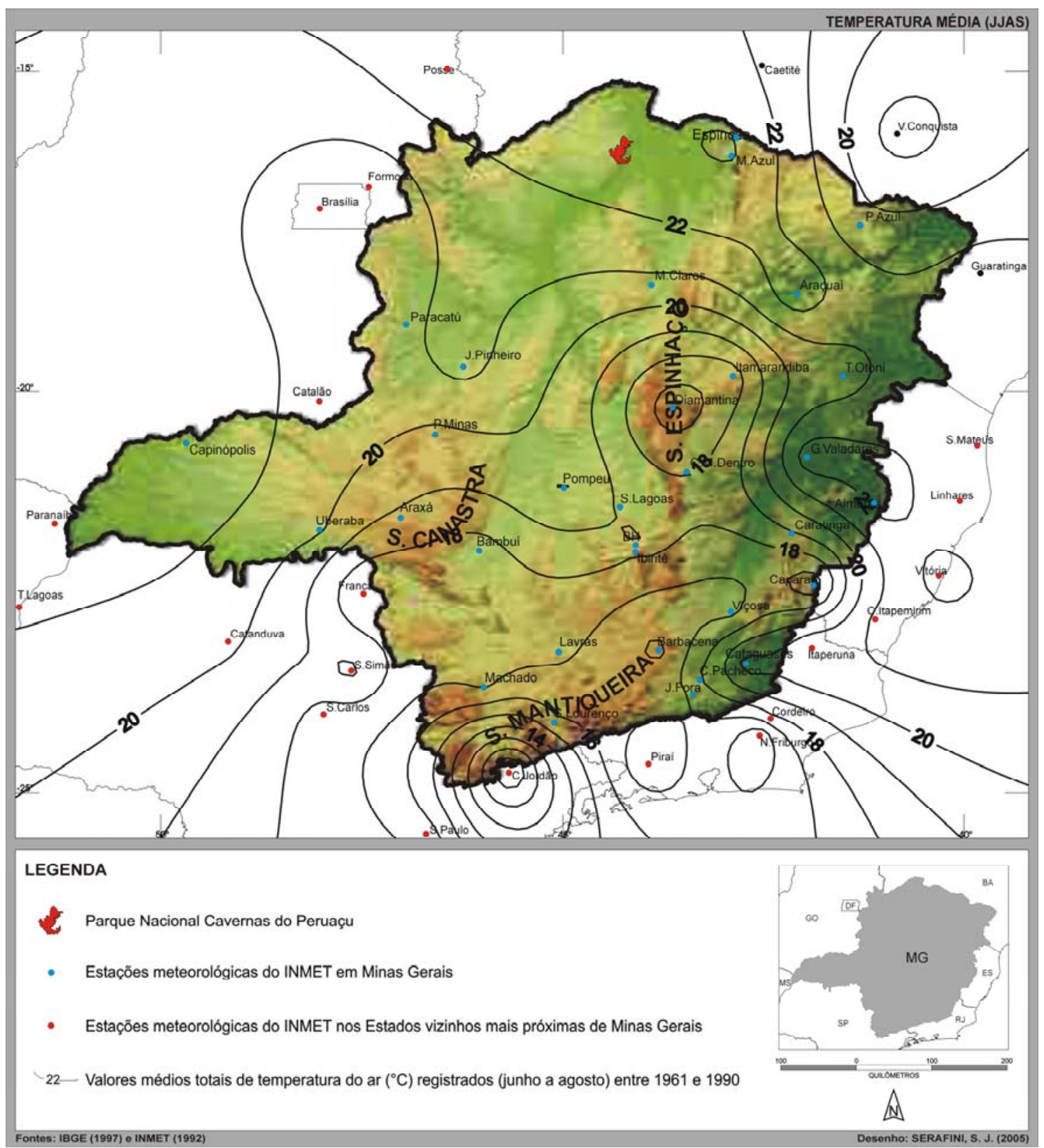

FIGURA 29: Temperatura média $\left({ }^{\circ} \mathrm{C}\right)$ no Estado de Minas Gerais, dos meses de junho, julho, agosto e setembro entre 1961 e 1990.

\subsection{A PLUVIOSIDADE}

O volume médio acumulado de chuva precipitada no Estado de Minas Gerais entre 1961 e 1990 foi de $1314 \mathrm{~mm}$, com mínima de $750 \mathrm{~mm}$ registrada na 


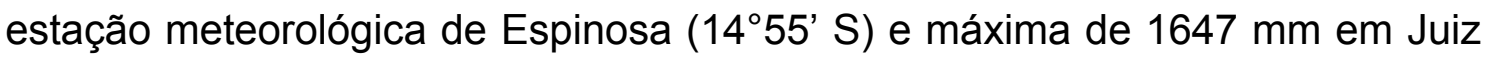
de Fora $\left(21^{\circ} 46^{\prime} \mathrm{S}\right)$.

Com base no volume total acumulado de chuvas nas estações meteorológicas instaladas no Estado de Minas Gerais, observa-se que os maiores volumes estão concentrados sobre as porções sul, sudoeste, oeste e noroeste, registrando volumes médios acima de $1400 \mathrm{~mm}$ anuais.

Esses volumes de chuva estão associados aos diferentes sistemas atmosféricos que circulam sobre estas porções e à ocorrência de episódios da ZCAS que respondem por grande parte do volume de chuvas na Região Sudeste como um todo.

Nas porções sudeste, sul e sudoeste do Estado é freqüente a passagem de sistemas frontais que também respondem por parte das chuvas na região em que está passando. Já nas porções oeste e noroeste, são trechos de circulação de sistemas atmosféricos produzidos na porção central do continente, oriundas da região amazônica e do Chaco.

Nas porções sudeste, leste, nordeste e norte, incluindo a porção central, notase que os volumes pluviométricos acumulados médios registrados são inferiores a $1400 \mathrm{~mm}$ ao longo do ano (Figura 30) em função da influência do clima semi-árido nordestino que se alonga para estas porções do Estado de Minas Gerais. 


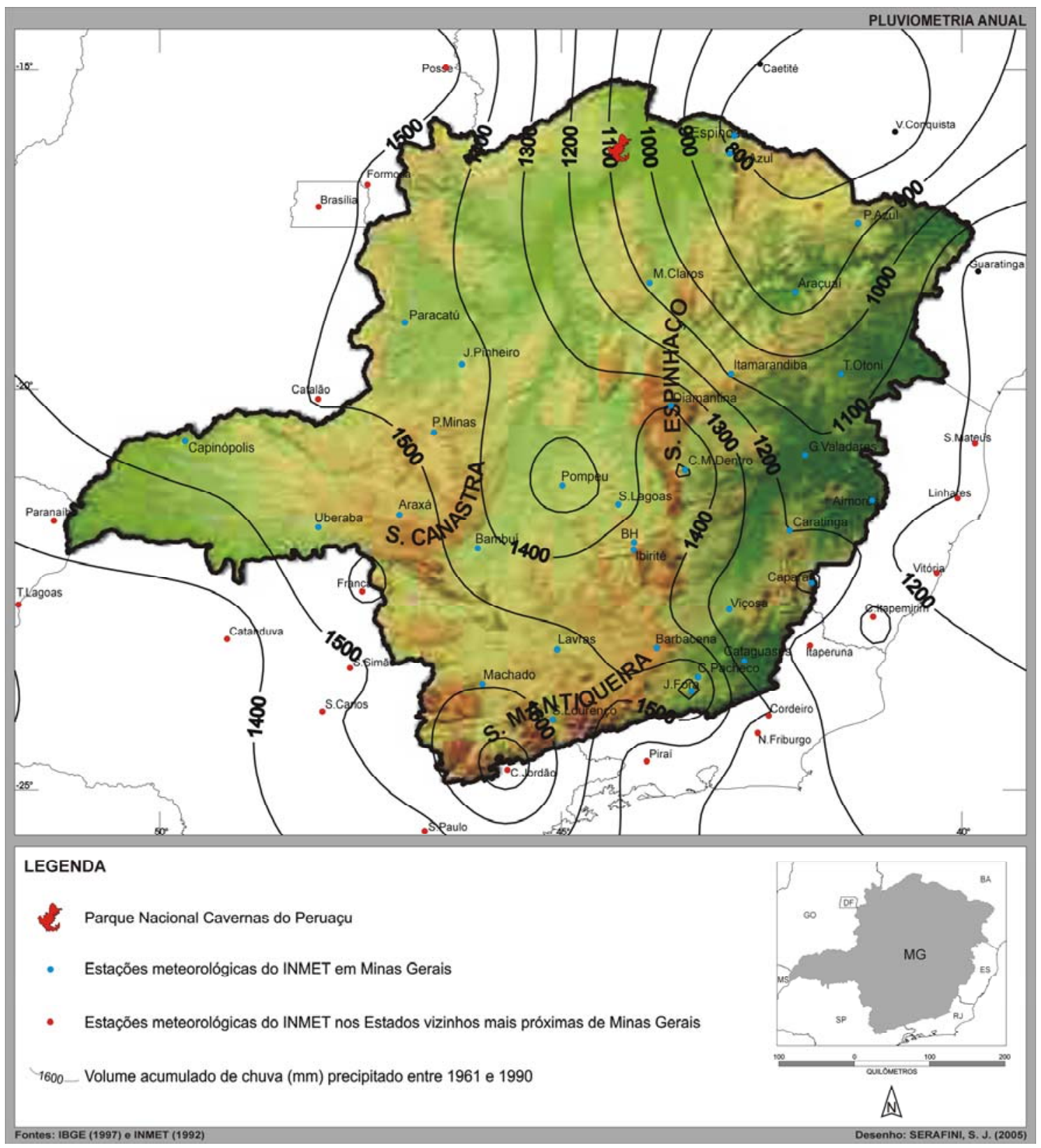

FIGURA 30: Volume de chuva $(\mathrm{mm})$ acumulado no Estado de Minas Gerais entre 1961 e 1990.

No Gráfico 02 são apresentados os volumes pluviométricos médios acumulados entre 1961 e 1990 nas estações meteorológicas do INMET de Minas Gerais (INMET, Op. Cit.), com destaque para as estações de Espinosa $(750 \mathrm{~mm})$ e Juiz de Fora $(1.647 \mathrm{~mm})$ que apresentaram os volumes mais extremos, registrando entre elas a maior amplitude pluviométrica do Estado para o mesmo período evidenciando assim, uma diferença relativa de volume de chuva segundo a influência das diferenças de latitudes e, sobretudo do clima semi-árido baiano. 
GRÁFICO 02: Volume de chuva acumulado nas estações meteorológicas do INMET entre 1961 e 1990.

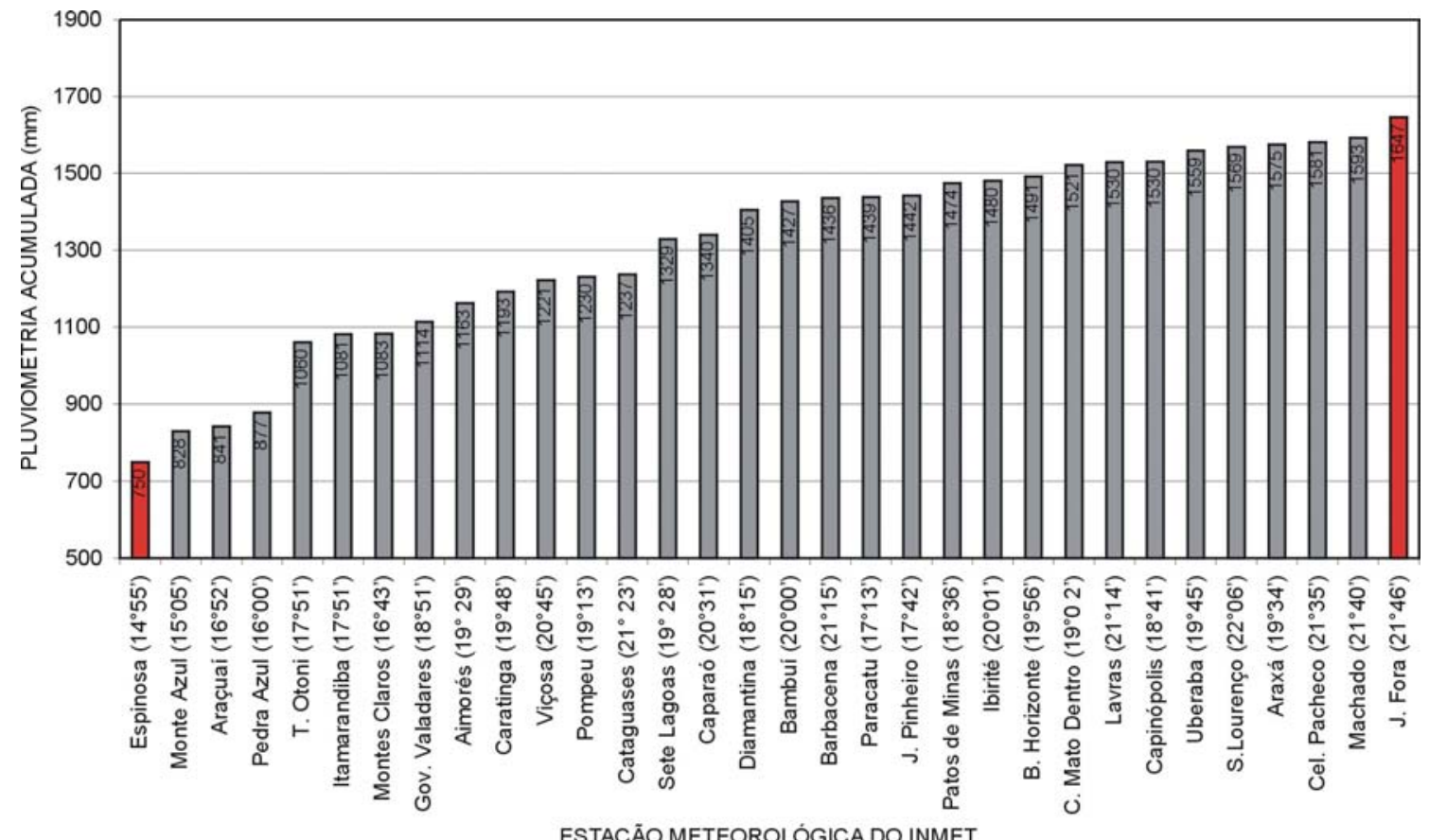

Fonte: INMET (1992).

Considerando os valores médios coletados entre 1961 e 1990 e distribuídos ao longo de um ano, observa-se que os meses de outubro a março apresentaram valores de precipitação média acumulada superior a $120 \mathrm{~mm}$, sendo que apenas os meses de novembro e dezembro registram volumes acumulados superiores a $200 \mathrm{~mm}$.

Em contrapartida, nos meses de maio a agosto, evidencia-se o período mais seco com médias de precipitação acumulada mensal, inferiores a $100 \mathrm{~mm}$, sendo que nos meses de junho, julho e agosto, os valores acumulados não ultrapassam os $20 \mathrm{~mm}$, representando assim, um volume reduzido em torno dos $90 \%$ do registrado nos meses de dezembro e janeiro (Gráfico 03).

No período quadrimestral de verão considerando os meses de dezembro, janeiro, fevereiro e março, as precipitações em todo o Estado, registram volumes totais acumulados que variam, aproximadamente, entre $485 \mathrm{~mm}$ registrados na estação meteorológica de Pedra Azul (16S) e 1042 mm na estação de Juiz de Fora ( $21^{\circ} 46^{\prime}$ S $)$, evidenciando uma amplitude de $558 \mathrm{~mm}$ entre estes dois pontos extremos do eixo norte sul de Minas Gerais. 
GRÁFICO 03: Volume de chuva acumulado mensalmente no Estado de Minas Gerais entre 1961 e 1990.

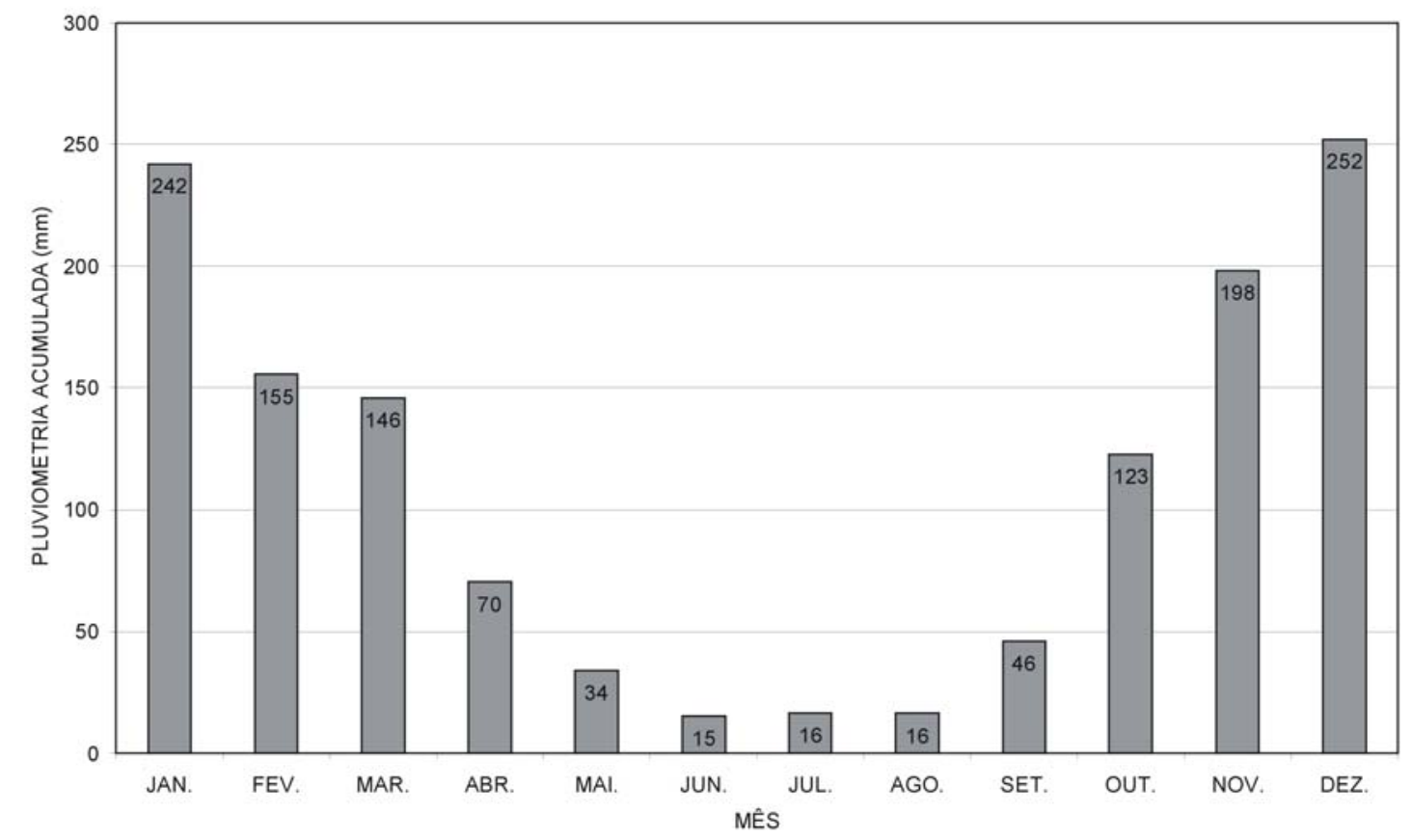

Fonte: INMET (1992).

Neste mesmo período, as chuvas se concentram sobre uma faixa territorial que se estende no sentido noroeste - sudeste, abrangendo quase todo o Triângulo Mineiro e alongando-se na direção sudeste até, aproximadamente os limites com os Estados de São Paulo e Rio de Janeiro (Figura 31).

No período de inverno, o que se vê, é um regime pluviométrico bem diferenciado, quando se registra para o mesmo período (1961 a 1990), um volume mínimo de chuva de $20 \mathrm{~mm}$ acumulados na estação meteorológica de Espinosa ( $\left.14^{\circ} 55^{\prime} \mathrm{S}\right)$ e máximo acumulado na estação de Machado (2140’ S), marcando uma amplitude de $150 \mathrm{~mm}$. 


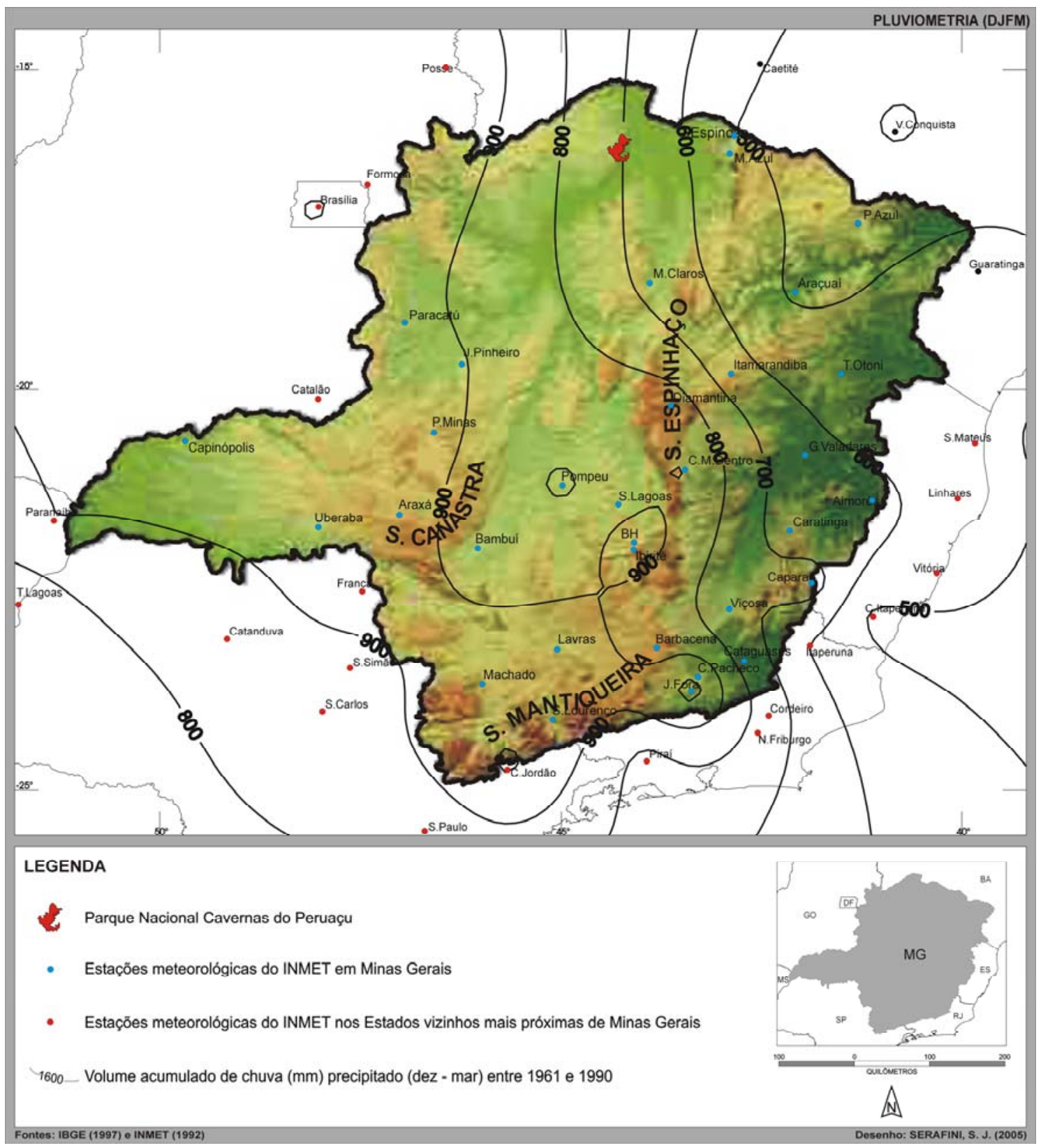

FIGURA 31: Volume de chuva $(\mathrm{mm})$ acumulado no Estado de Minas Gerais, nos meses de dezembro, janeiro, fevereiro e março entre 1961 e 1990.

Distribuindo os volumes de chuva deste período sobre o território de Minas Gerais, pode-se perceber que existe uma concentração de chuvas na faixa meridional do Estado que se estende por toda a faixa leste, posicionada paralelamente com o oceano e com a Serra do Mar que exerce importante influência na redução da umidade oceânica trazida pela massa de ar vindas do oceano, antes de chegar ao Estado (Figura 32). 


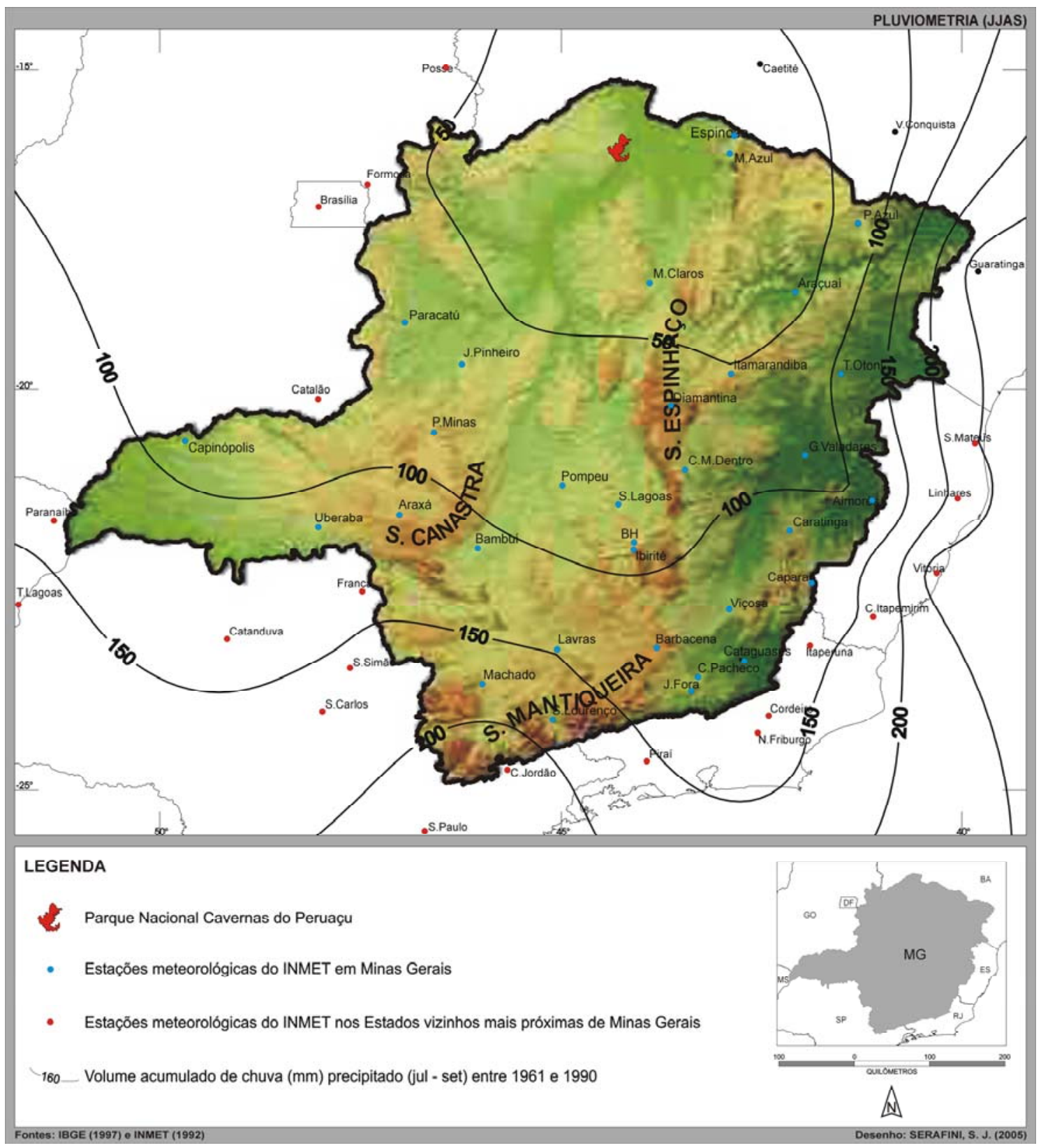

FIGURA 32: Volume de chuva $(\mathrm{mm})$ acumulado no Estado de Minas Gerais, nos meses de junho, julho, agosto e setembro entre 1961 e 1990.

A partir dos dados de temperatura e pluviosidade apresentados acima foi possível identificar os períodos considerados secos na porção norte de Minas Gerais mediante a elaboração de um gráfico de superfície onde foram projetados os valores obtidos pela expressão matemática "P $\leq 2 \mathrm{~T}$ ", proposta por GAUSSEN (Apud, GALVANI, 2005), relacionando os valores médios de precipitação $(\mathrm{P})$ e de temperatura $(\mathrm{T})$, para o mesmo período.

Quando a média de precipitação for igual ou menor a duas vezes a temperatura média de um determinado ambiente, portanto, valores negativos 
são considerados como um período seco; porém, quando estes valores se inverterem, registrando uma precipitação média superior ao dobro da temperatura média registrada, então o período observado, é considerado úmido.

Dessa forma, o clima no Estado de Minas Gerais, confere condição úmida entre os meses de setembro a abril e seco entre maio e agosto, como mostra a Tabela 01.

TABELA 01: Identificação do período seco e úmido no Estado de Minas Gerais (1961 a 1990).

\begin{tabular}{|c|c|c|c|c|c|}
\hline MÊS & $\begin{array}{c}\text { TEMP. } \\
\left({ }^{\circ} \mathrm{C}\right)\end{array}$ & $\begin{array}{c}\text { PRECIP. } \\
(\mathrm{mm})\end{array}$ & $2 \mathrm{~T}$ & $\mathrm{P} \leq 2 \mathrm{~T}$ & SITUAÇÃO \\
\hline Janeiro & 23 & 242 & 46 & 195,65 & ÚMIDO \\
\hline Fevereiro & 23 & 155 & 46 & 108,56 & ÚMIDO \\
\hline Março & 23 & 146 & 46 & 99,14 & ÚMIDO \\
\hline Abril & 22 & 70 & 44 & 26,56 & ÚMIDO \\
\hline Maio & 20 & 34 & 40 & $\mathbf{- 6 , 4 1}$ & SECO \\
\hline Junho & 18 & 15 & 36 & $\mathbf{- 2 1 , 5 4}$ & SECO \\
\hline Julho & 18 & 16 & 36 & $\mathbf{- 1 9 , 6 0}$ & SECO \\
\hline Agosto & 20 & 16 & 40 & $\mathbf{- 2 2 , 8 4}$ & SECO \\
\hline Setembro & 21 & 46 & 42 & 3,82 & ÚMIDO \\
\hline Outubro & 22 & 123 & 44 & 78,38 & ÚMIDO \\
\hline Novembro & 22 & 198 & 44 & 153,19 & ÚMIDO \\
\hline Dezembro & 23 & 252 & 46 & 206,83 & ÚMIDO \\
\hline
\end{tabular}

Fonte: INMET (1992).

Com os valores obtidos pela mesma expressão matemática para cada estação meteorológicas do INMET, foi possível montar um gráfico de superfície evidenciando um aumento do período seco em relação à diminuição da posição latitudinal de cada estação no Estado de Minas Gerais, mostrando que a porção norte de Minas Gerais onde está localizada a área de estudo apresenta um período seco mais longo, em torno de seis meses entre abril e outubro (Gráfico 04).

Num sistema dinâmico como é o atmosférico, a variação da temperatura interfere diretamente na quantidade de vapor contido na atmosfera sendo, portanto, considerado como um importante elemento para a compreensão climática de um dado ambiente. 
GRÁFICO 04: Identificação do período seco e úmido no Estado de Minas Gerais, segundo a expressão matemática " $P \leq 2 T$ " em cada estação meteorológica do INMET de Minas Gerais.

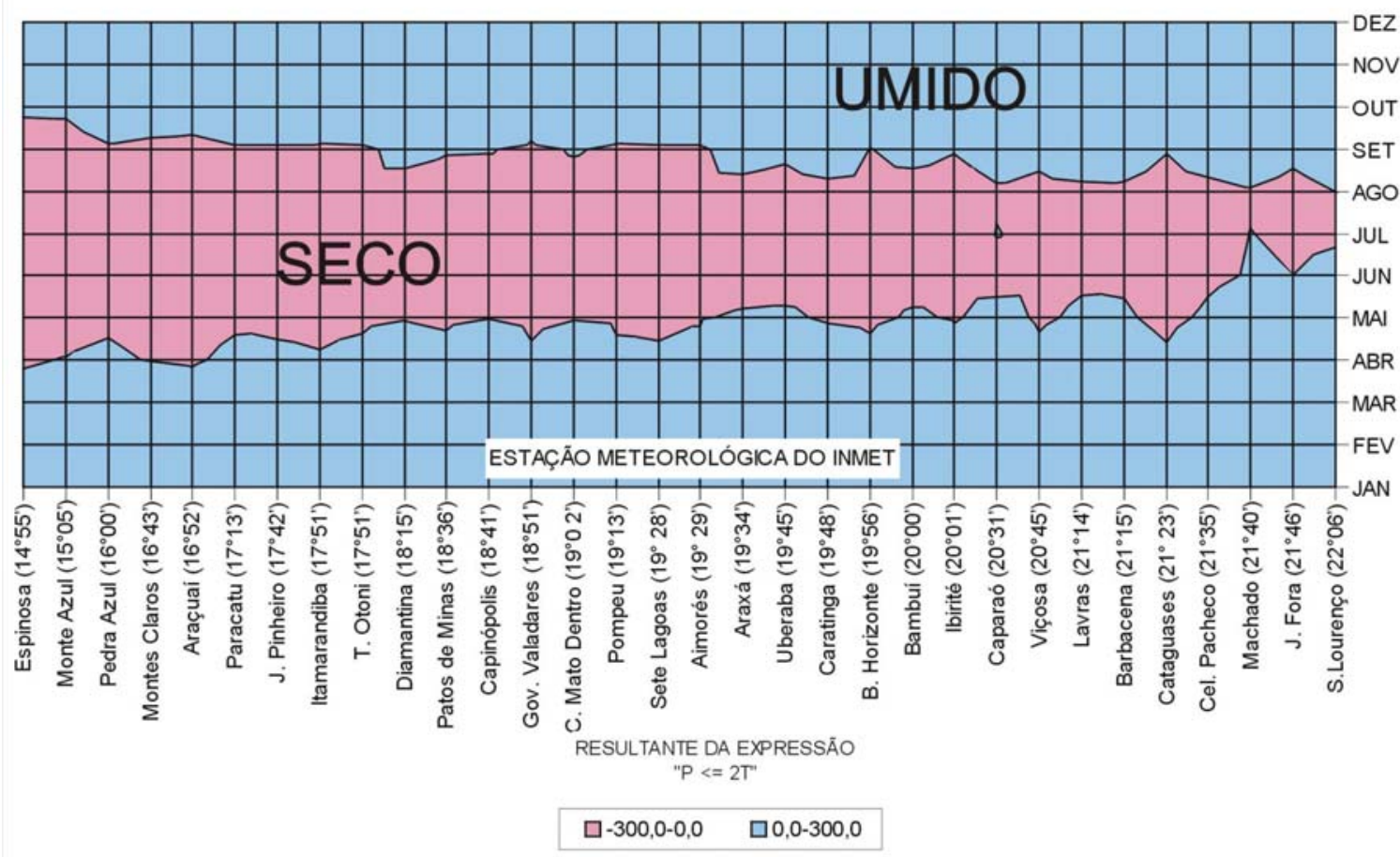

Fonte: INMET (1992).

Por esta importância, a seguir serão apresentadas as características de umidade relativa do ar registradas sobre o Estado de Minas Gerais.

\subsection{A UMIDADE RELATIVA DO AR}

A umidade relativa do ar, em linhas gerais, indica a existência de vapor d'água na atmosfera no que diz respeito ao grau de saturação do ar, informando o quão próximo ele está da saturação e condensação.

Considerando os dados climatológicos do INMET (op. cit.,1997) a umidade relativa do ar média registrada entre 1961 e 1990 foi de 75\%, com umidade média mínima de 60\% registrada na estação meteorológica de Espinosa

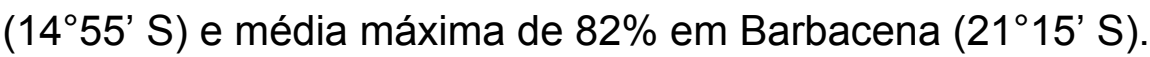

Como já fora observado, Espinosa é a estação mais setentrional do Estado de Minas Gerais e se encontra numa faixa de influência do clima semi-árido nordestino que, como tal, apresenta um período anual de estiagem de seis meses, enquanto Barbacena se localiza na Serra da Mantiqueira, ambiente favorável a concentração de umidade do ar trazida pelos ventos alísios após passarem pelo oceano. 
Observando a umidade relativa do ar média mensal ao longo de um período anual normal climatológico, verifica-se que durante sete meses (de novembro a maio) os valores médios ficaram acima da média normal (75\%) com valores que variaram entre 75 e $80 \%$, aproximadamente, enquanto que nos cinco meses restantes essa média mensal oscilou entre 67 e $75 \%$, aproximadamente.

Com base nisso, evidencia-se, como no caso da distribuição da temperatura, dois períodos anuais distintos quanto à quantidade de vapor d'água na atmosfera e seu potencial de saturação.

A partir da distribuição média da umidade relativa do ar no Estado de Minas Gerais verifica-se que não apenas Barbacena, mas grande parte da sua porção sul apresenta valores mais elevados indicando, portanto, ser um ambiente potencialmente mais propício à saturação do ar e ocorrência de chuvas.

Ainda na porção sul, a umidade relativa do ar média anual para o período de 1961 a 1990 concentra-se, predominantemente, sobre uma faixa que se alonga no sentido sudoeste / nordeste acompanhando a região do complexo da Serra do Mar (entre as estações meteorológicas de São Lourenço e Teófilo Otoni) que como tal, mantém sobre ela a floresta tropical pluvial atlântica.

Nesta faixa são registrados valores médios de umidade relativa do ar acima de $76 \%$, ressalvando as estações meteorológicas de Caratinga, Viçosa, Barbacena e Juiz de Fora, que registraram médias acima de $80 \%$, influenciadas, entre outros aspectos, por serranias ali existentes, entre elas, a própria Serra da Mantiqueira localizada naquele trecho.

$\mathrm{Na}$ porção norte do Estado, diferentemente das porções mais ao sul, a umidade relativa do ar média registrada aponta valores inferiores a $70 \%$, sendo que nas estações meteorológicas de Espinosa e Monte Azul, o valor médio registrado entre elas é de $60 \%$, aproximadamente.

Este setor extremo norte do Estado, como já fora observado em relação à temperatura, mantém características de umidade do ar que são influenciadas diretamente pela faixa do semi-árido localizado ali próximo, conferindo características na composição florística de cerrado e caatinga. 
Em relação à distribuição da umidade relativa do ar média nos períodos de inverno e verão foi observado que no verão há uma distribuição mais homogênea do vapor d'água sobre o território mineiro.

Neste período foram registrados valores médios acima de $70 \%$ em praticamente todas as estações meteorológicas, com exceção na estação de Espinosa que, mais uma vez, registrou um valor médio inferior (67\%), embora no setor extremo norte (localização da área de estudo), são mantidos os baixos valores de umidade relativa do ar em ambos os períodos em relação a todo Estado.

Entre todas as estações é registrada uma amplitude de apenas 17\%, com uma taxa mínima registrada de $67 \%$ de umidade média na estação de Espinosa e máxima de $84 \%$ na estação meteorológica de Barbacena.

No período de inverno, quando as condições atmosféricas apresentam-se favoráveis à formação de tempos estáveis devido à presença predominante de massas de ar de alta pressão, observam-se um relativo confinamento das áreas mais úmidas, predominantemente, na porção central do Estado, registrando valores acima de $74 \%$.

Essa concentração de umidade relativa do ar, também pode ser registrada nos trechos localizadas nas proximidades do limite interestadual com São Paulo onde a presença da Serra da Mantiqueira exerce sua influência na garantia de manutenção de taxas médias acima de $78 \%$.

Nas Figuras 33 e 34 a seguir, é apresentada a distribuição dos valores de umidade relativa do ar nos períodos de verão e inverno, respectivamente. 


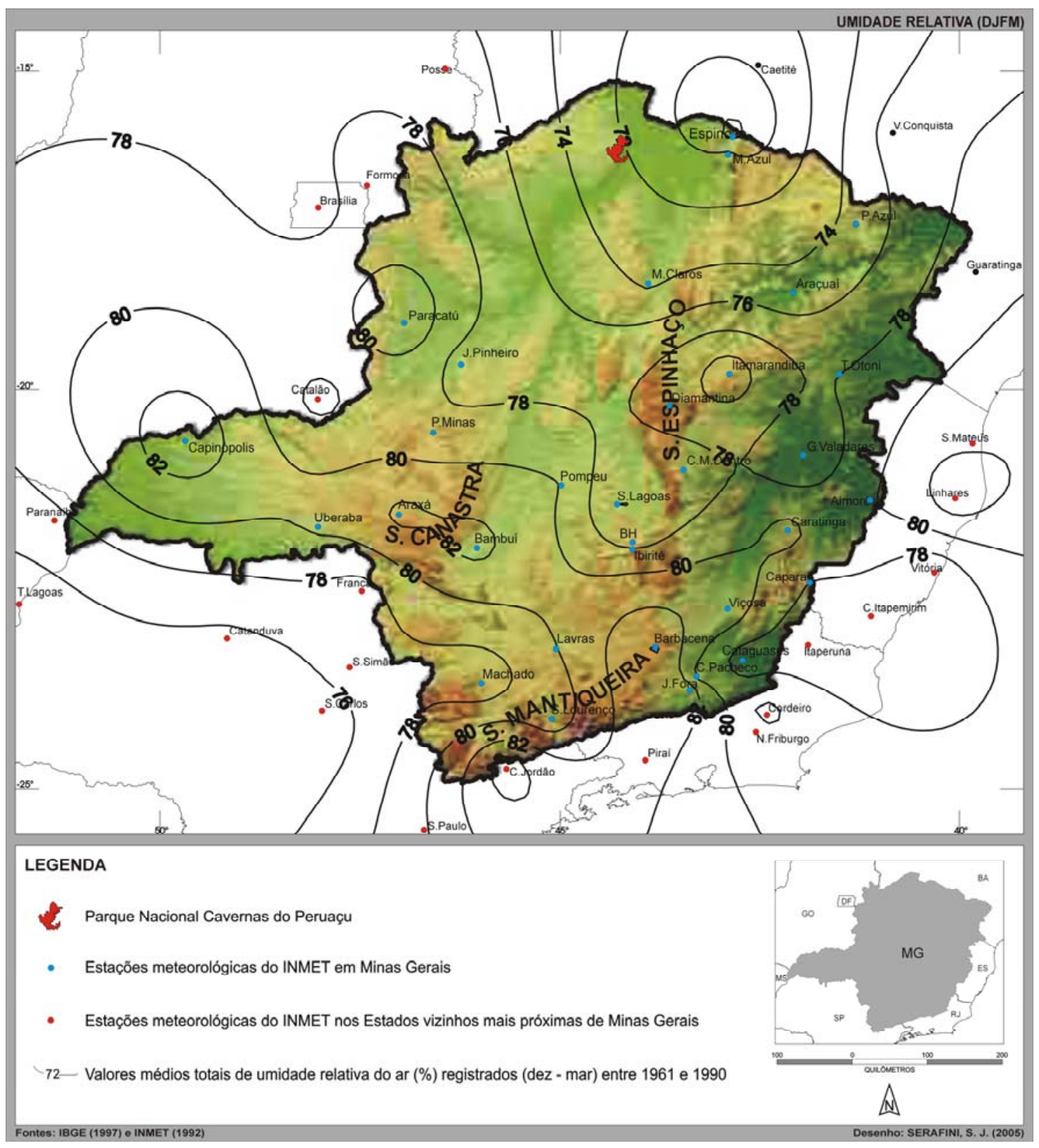

FIGURA 33: Umidade relativa do ar (\%) média no Estado de Minas Gerais dos meses de dezembro, janeiro, fevereiro e março entre 1961 e 1990. 


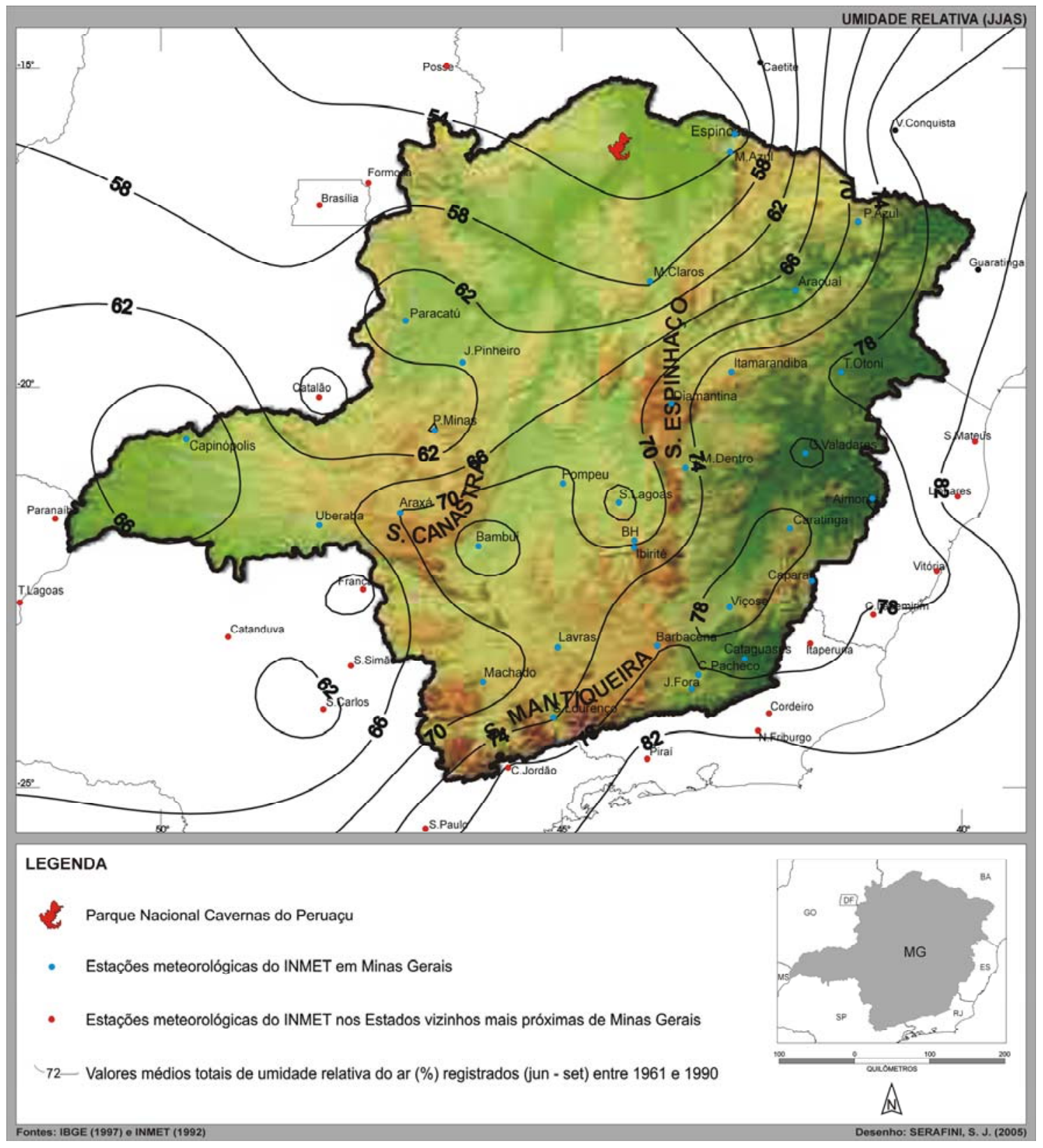

FIGURA 34: Umidade relativa do ar (\%) média no Estado de Minas Gerais dos meses de junho, julho, agosto e setembro entre 1961 e 1990.

A seguir será apresentada a descrição do processo dinâmico atmosférico ocorrente nos meses de julho de 2003 e janeiro de 2004, coincidindo com o período de registro dos dados climáticos na área de estudo. 


\section{A CARACTERIZAÇÃO CLIMÁTICA LOCAL SAZONAL}


Neste capítulo, a caracterização climática local será apresentada em relação aos meses em que foram realizados os trabalho de campo (julho de 2003 e janeiro de 2004) e será iniciada pela caracterização da circulação atmosférica registrada em cada um destes meses, pretendendo, concomitantemente, associá-la com a variação média diária da pressão barométrica, nebulosidade, temperatura e umidade relativa do ar, além do volume de chuva registrado apenas no mês de janeiro de 2004 em função de julho do ano anterior ser um período tipicamente seco quando não foi registrado qualquer evento de chuva durante o trabalho de campo.

\subsection{EM JULHO DE 2003}

\subsubsection{A CIRCULAÇÃO ATMOSFÉRICA E TIPOS DE TEMPO ASSOCIADOS NA ESCALA DIÁRIA}

Em julho de 2003, segundo o relatório mensal publicado pelo INPE (op. cit., 2003) foi registrada a passagem de sistemas frontais de fraca intensidade e massas de ar frio que atuaram sobre a Região Sudeste avançando para o oceano.

Com base na observação das imagens do satélite METEOSAT, disponível no sítio do INPE (www.inpe.br), verificou-se que estes sistemas (frontais e de alta pressão) quando chegavam sobre as porções norte da Região Sul e sul da Região Sudeste começavam a desviar para o oceano, interferindo muito pouco no norte de Minas Gerais onde está localizada a área de estudo.

\subsubsection{Entre os dias 01 e 02 de julho de 2003.}

No final de junho, predominava sobre a região central do Brasil um sistema de alta pressão que permaneceu sobre a região até o início de julho enquanto na Região Sul já avançava um sistema frontal vindo da Argentina, passando sobre o litoral do Paraná e São Paulo durante os dois primeiros dias de julho.

A ação de um sistema de alta pressão no final de junho e começo de julho pode ser identificado indiretamente na área de estudo através dos registros de pressão atmosférica local que no primeiro dia do mês registrou um dos maiores valores médios de todo período $(964 \mathrm{hPa})$, declinando progressivamente até o dia 6 . 
Já sobre o oceano, na altura de São Paulo, esse sistema frontal vindo da Argentina encontra com outra massa de ar frio fazendo com que parte da faixa de instabilidade se desvie para o interior norte de Minas Gerais (Figura 35), levando nebulosidade sobre a área de estudo que foi identificada já no dia 2 com registro médio de cobertura do céu em torno dos $90 \%$.

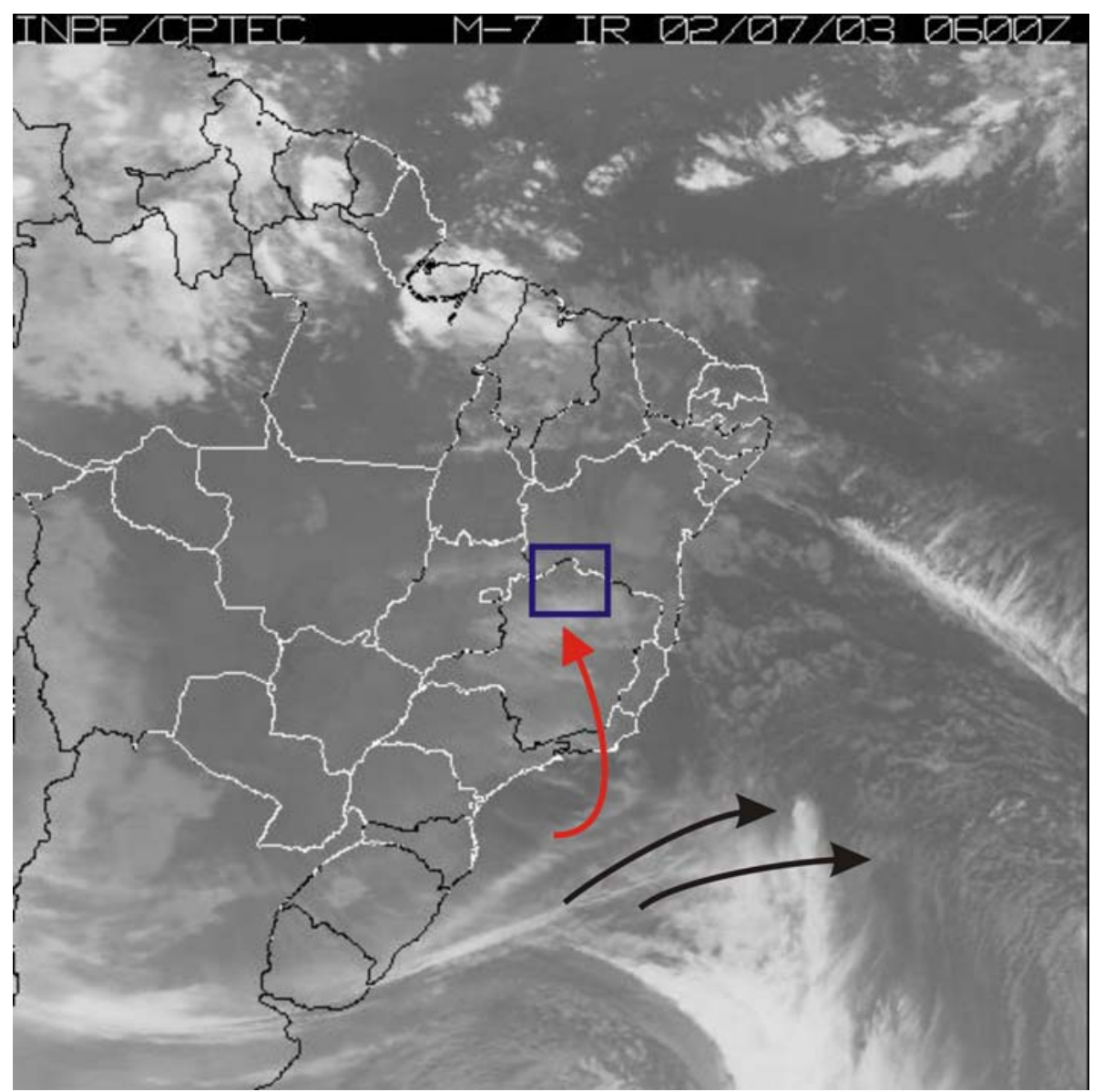

FIGURA 35: Passagem de uma frente fria sobre o oceano na altura da Região Sul do Brasil (indicada pelas setas pretas), registrando o desvio (indicado pela seta vermelha) de uma faixa de instabilidade sobre o interior norte de Minas Gerais (moldura azul), onde está localizado o Parque Nacional Cavernas do Peruaçu.

\subsubsection{Entre os dias 03 e 08 de julho de 2003.}

Logo após a passagem dessa frente fria sobre o oceano, no dia 3 já foi possível identificar o avanço da primeira massa de ar frio de julho que se deslocou sobre o litoral brasileiro até dia 4, ficando estacionada na altura dos Estados do Rio de Janeiro, Espírito Santo e sul da Bahia até o dia 7.

Nesse período, sobre o território mineiro foi observada, concomitantemente, a ação de um outro sistema continental de alta pressão garantindo maior estabilidade atmosférica, período em que a pressão barométrica média 
registrada na área de estudo manteve-se mais baixa durante todo o mês de julho, variando entre 958 e $961 \mathrm{hPa}$ entre os dias 3 e 9.

Neste mesmo período, as observações sobre nebulosidade registraram dias praticamente sem cobertura de nuvem, interferindo na quantidade de radiação solar recebida na superfície, influenciando as características térmicas da área de estudo, quando foram registradas temperaturas médias diárias entre 18 e 26 ${ }^{\circ} \mathrm{C}$ e média total de $22,9^{\circ} \mathrm{C}$, mantendo-se assim como um dos períodos mais quentes do mês.

Relacionada diretamente com a temperatura, entre os dias 3 e 8 , a umidade relativa do ar média diária registrada marcou um dos períodos mais secos de julho, com média total de $47 \%$, no mesmo período.

Esse sistema continental de alta pressão a partir do dia 9 começou a perder força devido à aproximação da segunda frente fria vinda do norte da Argentina, fazendo com que o eixo de deslocamento desse sistema frontal atravessasse o território brasileiro no sentido sudoeste - nordeste, passando sobre os Estado do Mato Grosso do Sul e sul de Minas Gerais entre os dias 5 e 8 de julho, antecedendo a entrada de outra massa de ar frio sobre o território mineiro.

\subsubsection{Entre os dias 09 e 14 de julho de 2003.}

Essa massa de ar frio (configurada como um sistema de alta pressão) permaneceu com mais força sobre o território mineiro entre os dias 9 e 11, quando a pressão barométrica média na área de estudo registrou uma elevação progressiva de 954 hPa no dia 9 para 964 hPa no dia 14.

No dia 11 mesmo, sobre o sul de Minas Gerais (próximo à localidade de Patos de Minas), como mostra a Figura 36, a entrada da terceira frente fria com pouquíssima influência sobre a área de estudo, trazendo com ela apenas células de nebulosidade moderada que se projetaram sobre o Parque Nacional Cavernas do Peruaçu entre os dias 11 e 14 que influenciaram as características térmicas e higrométricas da área de estudo.

Neste período, a cobertura do céu apresentou uma variação média em torno dos $10 \%$ no dia 12 , aumentando para $50 \%$ no dia 13 e reduzindo para $15 \%$ no dia 14. 
Com o aumento da nebulosidade, a temperatura média diária registrada na área de estudo no mesmo período foi marcada por um esfriamento de $26,4^{\circ} \mathrm{C}$ para $21,4^{\circ} \mathrm{C}$, intercalado por uma pequena elevação entre os dias 10 e 12 quando a temperatura média diária registrada neste dia foi de $27,1^{\circ} \mathrm{C}$ no dia 12 , identificado como o dia mais quente de julho de 2003 dentro da área de estudo.

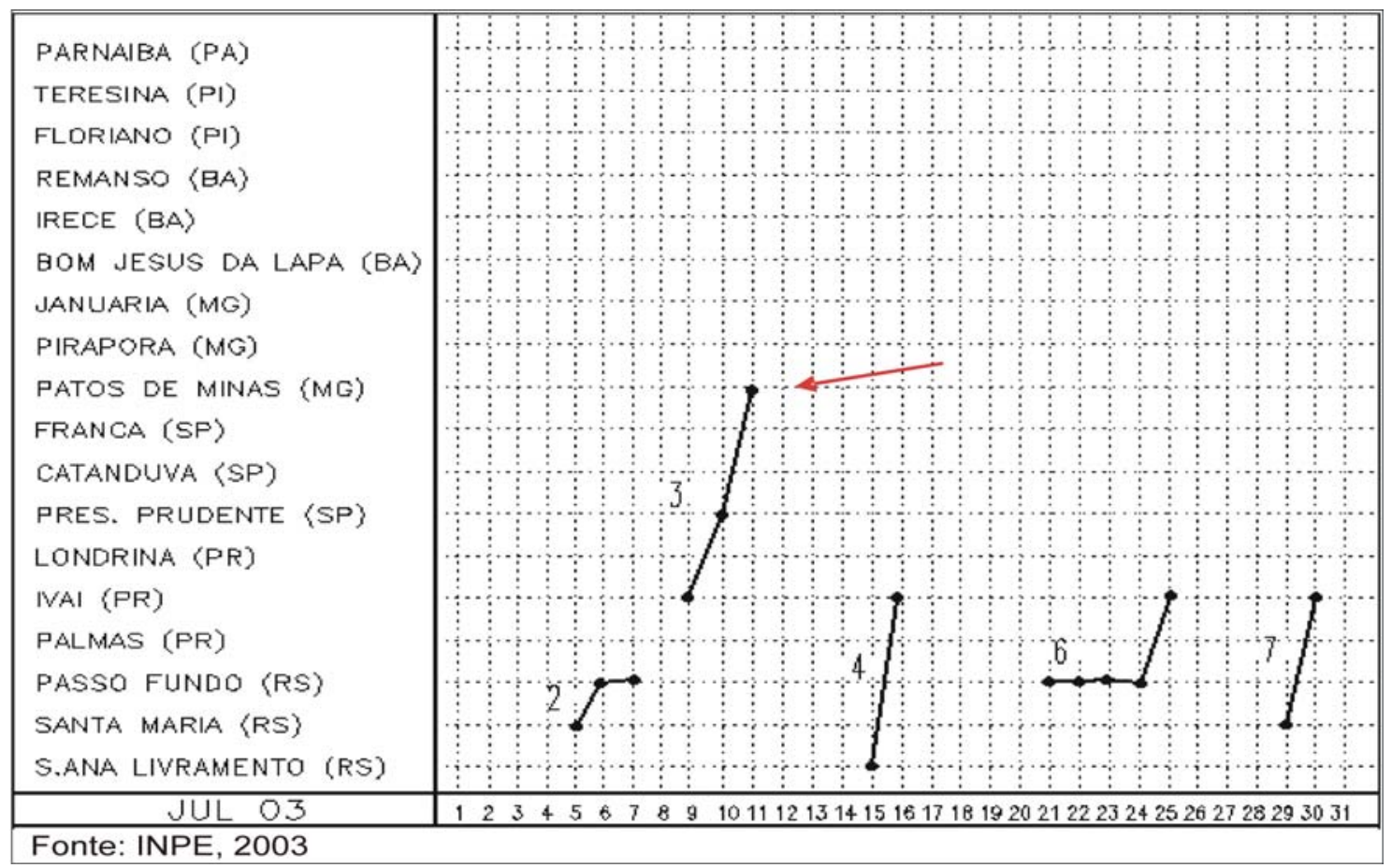

FIGURA 36: Registro da passagem da terceira frente fria sobre o território mineiro, próximo á Patos de Minas no dia 11 de julho de 2003, quando foi observado um ligeiro aumento da nebulosidade no Parque Nacional Cavernas do Peruaçu.

\subsubsection{Entre os dias 15 e 19 de julho de 2003.}

Logo após a passagem dessa terceira frente fria com pouca influência sobre a área de estudo, observa-se o avanço de outra massa de ar frio entre os dias 14 e 19 sobre a porção leste da Região Sudeste, trazendo com ela extensas áreas recobertas por nuvens que se espalha por todo Estado de Minas Gerais.

Com o avanço dessa outra massa de ar frio, é mantida a elevação dos valores barométricos registrados no Parque Nacional Cavernas do Peruaçu neste período, com pressão máxima média um pouco acima dos $965 \mathrm{hPa}$ registrado no dia 18.

Embora tenha sido registrado um aumento da pressão a aproximação da massa de ar frio de alta pressão, não impediu a presença de nuvens que, neste 
período foi marcado como o primeiro em que a nebulosidade manteve-se com uma média de $20 \%$ da cobertura total, registrando as máximas entre os dias 15 e 16 de 34 e $38 \%$, respectivamente.

Com um episódio representativo de nebulosidade sobre a área de estudo, foi registrada uma ligeira queda de temperatura e aumento da umidade relativa do ar neste período, variando entre 23 e $25^{\circ} \mathrm{C}$ e 42 a $55 \%$, respectivamente.

\subsubsection{Entre os dias 20 e 31 de julho de 2003.}

A partir do dia 19, a massa de ar frio identificada no período anterior estava sobre o oceano entre os Estados do Rio de Janeiro, Espírito Santo e Bahia, iniciando um processo de tropicalização, modificando suas características

originais (fria e seca), para aquelas típicas da faixa inter-tropical (quente e úmida).

Entre os dias 20 e 27 essa massa de ar tropicalizada mantém-se estacionada interferindo na variação climática da área de estudo neste período com o avanço do oceano para o norte de Minas Gerais de grande quantidade de umidade levados pelas correntes de ventos.

A partir do dia 27, esta massa de ar quente e úmida cede lugar ao avanço de outra massa de ar frio que passa brevemente sobre o litoral da Região Sul e Sudeste, precedendo a última frente fria que avança em direção ao oceano, constituindo-se numa banda de nebulosidade alinhada no sentido sudeste/noroeste sobrepondo todo o Estado de Minas Gerais.

Nestes últimos dez dias de julho, a variação da pressão atmosférica sofre pequenas variações entre 962 e $964 \mathrm{hPa}$, registrando maior valor no dia 26, ligeiramente acima dos $964 \mathrm{hPa}$.

\subsubsection{Considerações sobre a circulação atmosférica e os tipos de tempo de julho de 2003}

Relacionando essa dinâmica dos sistemas atmosféricos com a variação da pressão atmosférica local, assim como nebulosidade, temperatura e umidade relativa no mesmo período, foram observados os seguintes aspectos:

A pressão barométrica ao longo do mês de julho de 2003 variou entre 958 e $964 \mathrm{hPa}$, quando foram observadas três principais períodos de elevação, 
coincidindo com a aproximação das massas de ar frio, notadamente sistemas de alta pressão.

A presença de nuvens sobre a área de estudo marcou dois episódios representativos acima dos $20 \%$ de cobertura total (13 a 17 e 22 a 31 de julho de 2003) associados, respectivamente, ao avanço de uma massa de ar fria e ao avanço de uma frente fria sobre o Estado de Minas Gerais.

As temperaturas médias diárias oscilaram predominantemente entre 23 e $25^{\circ} \mathrm{C}$, sendo que entre os dias 9 e 12 de julho de 2003, as temperaturas médias diárias estiveram entre 26 e $27^{\circ} \mathrm{C}$, provavelmente associada a pouca cobertura de nuvens registrada nestes dias, possibilitando a entrada de maior quantidade de radiação solar, aquecendo mais intensamente a superfície da área de estudo, onde foram registrados os dados de temperatura.

Associada à variação da temperatura, a umidade relativa do ar média diária apresentou na primeira quinzena de julho de 2003, valores abaixo dos $50 \%$, com destaque para os dias 3, 10 e 11 que registraram taxas de umidade relativa inferiores a $40 \%$.

Nos Gráficos 5, 6, 7 e 8, apresentados abaixo são mostradas as variações diárias médias de pressão barométrica, nebulosidade, temperatura e umidade relativa do ar em que foram registrados tendo como pano de fundo a circulação atmosférica descrita para o mês de julho de 2003.

GRÁFICO 05: Variação diária média da pressão barométrica registrada no mês de julho no Parque Nacional Cavernas do Peruaçu.

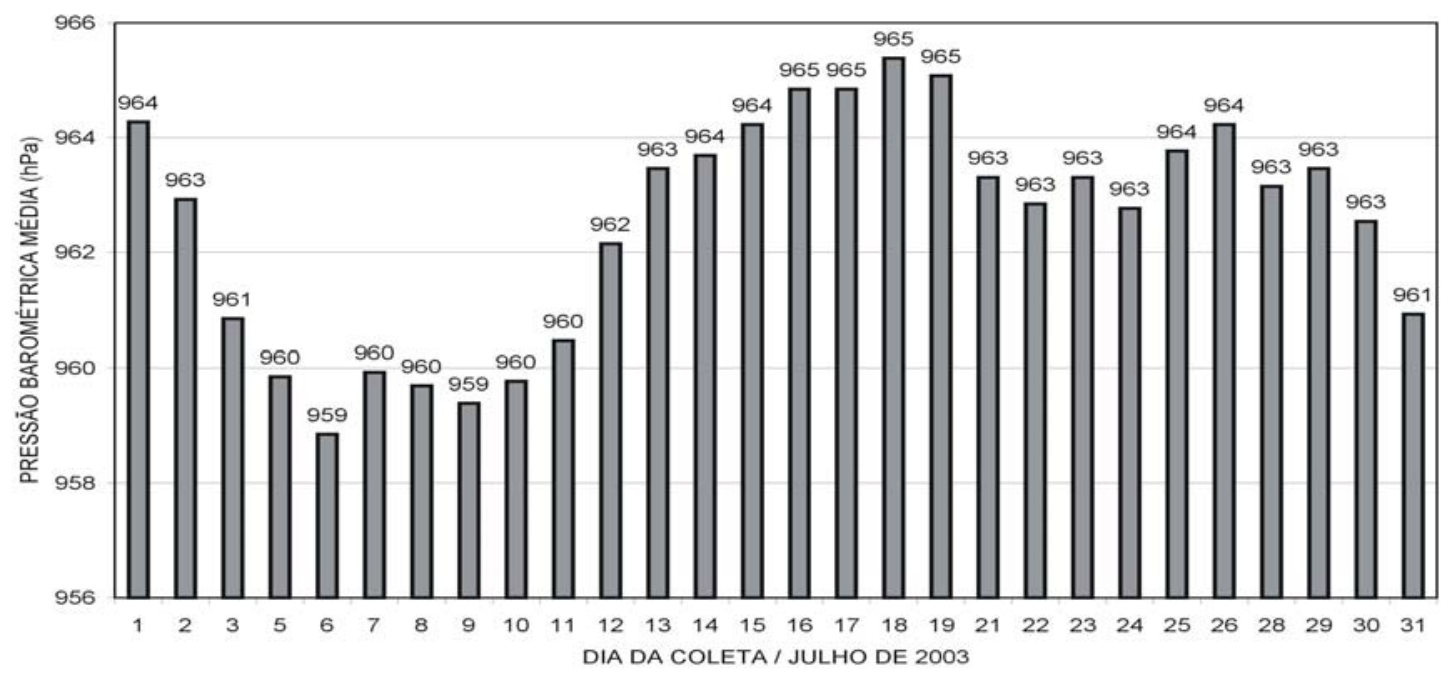

Fonte: Dados registrados em campo (julho de 2003). 
GRÁFICO 06: Variação diária média da nebulosidade registrada no mês de julho no Parque Nacional Cavernas do Peruaçu.

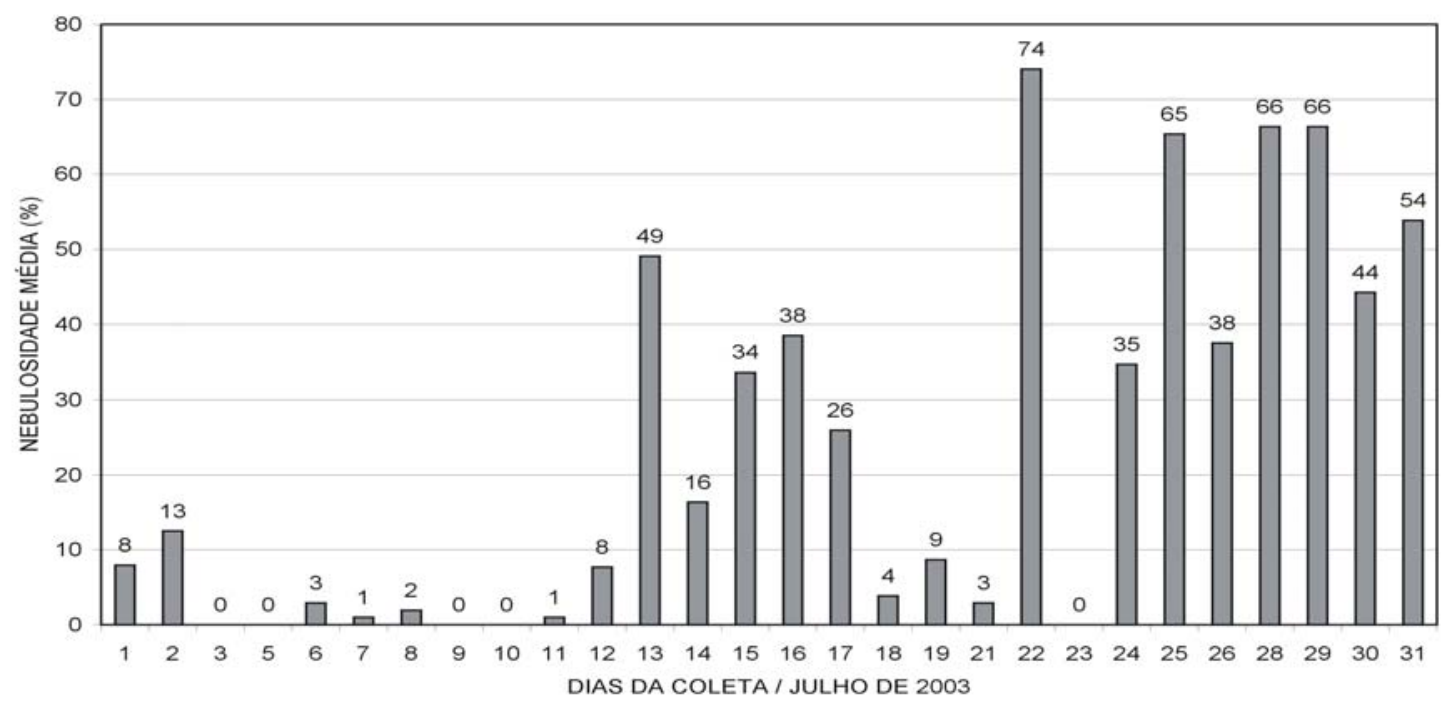

Fonte: Dados registrados em campo (julho de 2003).

GRÁFICO 07: Variação diária média da temperatura do ar registrada no mês de julho no Parque Nacional Cavernas do Peruaçu.

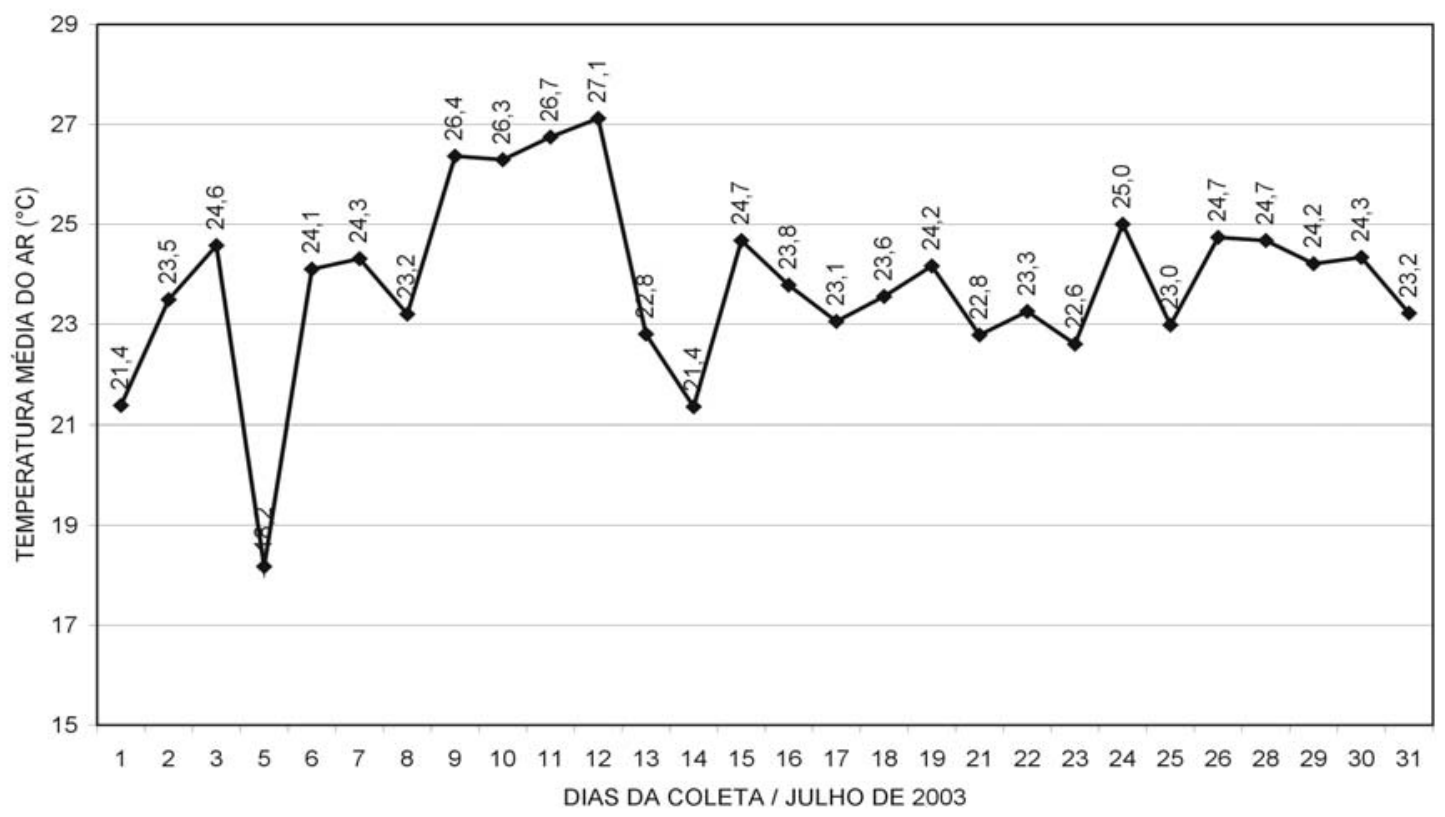

Fonte: Dados registrados em campo (julho de 2003). 
GRÁFICO 08: Variação diária média da umidade relativa do ar registrada no mês de julho no Parque Nacional Cavernas do Peruaçu.

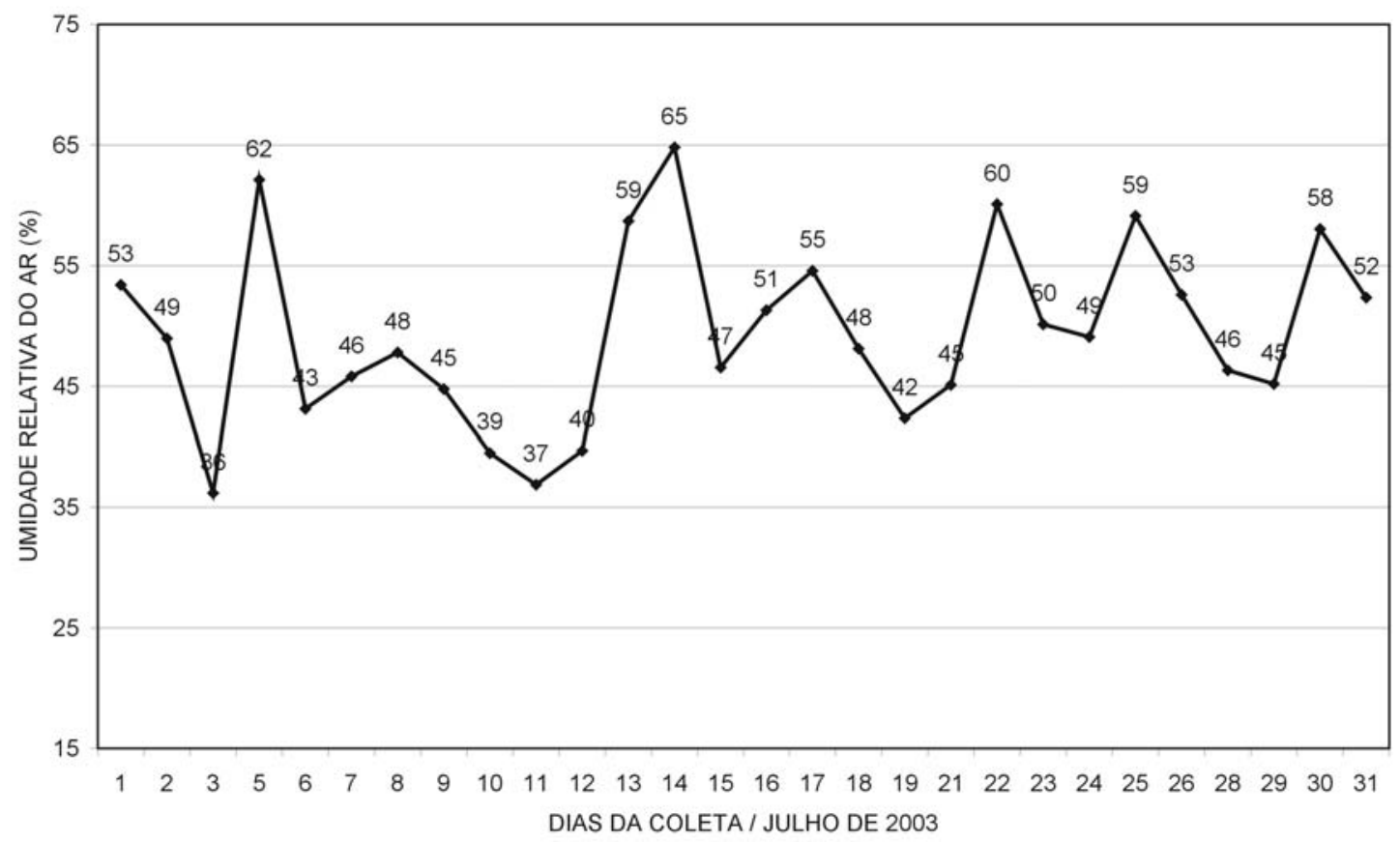

Fonte: Dados registrados em campo (julho de 2003).

\subsubsection{A TEMPERATURA DO AR}

Com base nos dados de campo coletados em julho de 2003 no Parque Nacional Cavernas do Peruaçu e seu entorno, a temperatura média obtida foi de $23,8^{\circ} \mathrm{C}$ para todo o período, com a mínima e a máxima absolutas de $7,2^{\circ} \mathrm{C}$ (Ponto $n^{\circ} .23$ ) e $32,4^{\circ} \mathrm{C}$ (Ponto $n^{\circ} .35$ ), respectivamente.

Comparando a temperatura média deste período $\left(23,8^{\circ} \mathrm{C}\right)$ com a normal climatológica das estações meteorológicas do INMET mais próximas à área de estudo (Espinosa, Formosa, Monte Azul, Montes Claros e Posse) (Tabela 02), pode-se observar que o Parque Nacional Cavernas do Peruaçu apresentou uma temperatura média mais elevada em relação à condição térmica média registrada entre 1961 e $1990\left(21,9^{\circ} \mathrm{C}\right)$. 
TABELA 02: Temperatura média $\left({ }^{\circ} \mathrm{C}\right)$ entre 1961 e 1990 no mês de julho nas estações meteorológicas do INMET circundantes ao Parque Nacional Cavernas do Peruaçu e temperatura média $\left({ }^{\circ} \mathrm{C}\right)$ desta Unidade de Conservação em julho de 2003.

\begin{tabular}{l|l|c}
\hline \multicolumn{1}{c|}{$\begin{array}{c}\text { PERÍODO } \\
\text { CONSIDERADO }\end{array}$} & \multicolumn{1}{|c|}{ NOME } & TEMPERATURA MÉDIA ( $\left.{ }^{\circ} \mathrm{C}\right)$ \\
\hline \multirow{4}{*}{$1961-1990$} & ESPINOSA & 21,8 \\
\cline { 2 - 3 } & FORMOSA & 18,9 \\
\cline { 2 - 3 } & MONTE AZUL & 22,1 \\
\cline { 2 - 3 } & MONTES CLAROS & 19,4 \\
\cline { 2 - 3 } & POSSE & 21,9 \\
\cline { 2 - 3 } & MÉDIA (1961 - 1990) & 21,9 \\
\hline \multirow{2}{*}{ JULHO DE 2003} & $\begin{array}{l}\text { PARQUE NACIONAL CAVERNAS } \\
\text { DO PERUAÇU }\end{array}$ \\
\hline
\end{tabular}

Fonte: Dados registrados em campo (julho de 2003).

Neste período (julho de 2003), as temperaturas registradas nos pontos de amostragem mais recorrentes concentraram-se entre 26 e $28^{\circ} \mathrm{C}$, representando juntas $29 \%$ de toda a amostra.

Outra classe representativa de temperaturas registradas nos pontos de amostragem compreende as temperaturas entre 16 e $24^{\circ} \mathrm{C}$ e entre 30 e $32^{\circ} \mathrm{C}$ que representam $63 \%$ de todos os valores obtidos na escala horária (Gráfico 9).

Considerando a temperatura média de cada ponto de amostragem verifica-se que:

- $7 \%$ deles (dois pontos de amostragem) registraram temperaturas médias entre 14 e $20^{\circ} \mathrm{C}$;

- $80 \%$ (24 pontos) temperaturas entre 20 e $25^{\circ} \mathrm{C}$; e,

- $13 \%$ (quatro pontos) apresentaram temperaturas médias para todo 0 período que variaram entre 25 e $28^{\circ} \mathrm{C}$. 
GRÁFICO 09: Distribuição de freqüência (\%) da temperatura $\left({ }^{\circ} \mathrm{C}\right)$ registrada no Parque Nacional Cavernas do Peruaçu (julho de 2003).

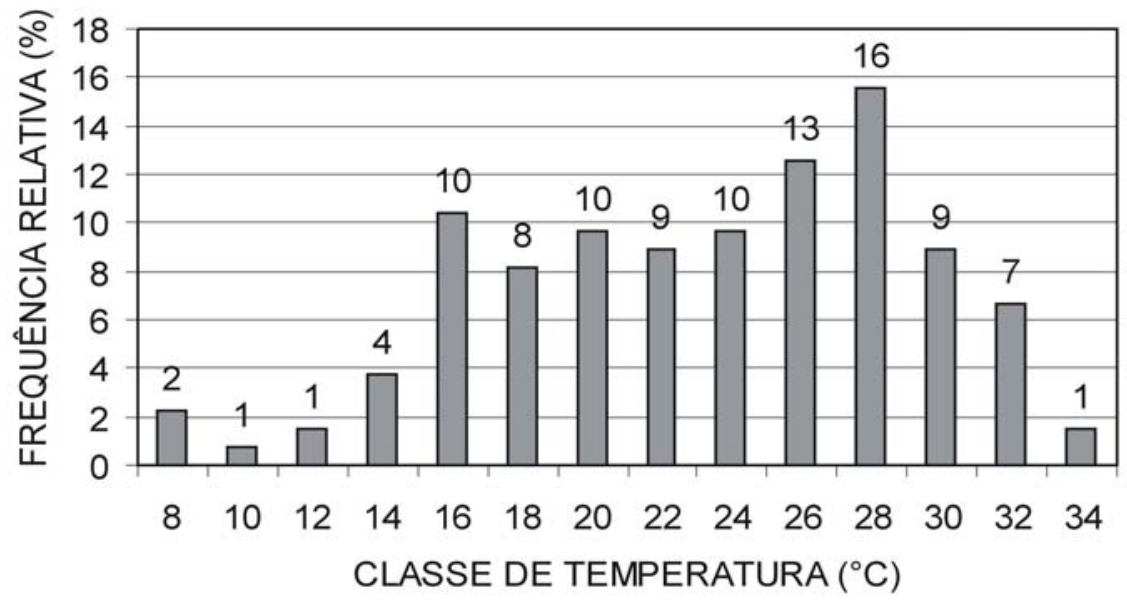

Fonte: Dados registrados em campo (julho de 2003).

Distribuindo esses valores médios em relação à freqüência com que foram registrados, tem-se que as temperaturas médias mais recorrentes oscilaram 24 e $26^{\circ} \mathrm{C}$, representando $73 \%$ de toda a amostragem média de temperatura dos pontos, como podem ser observados no Gráfico 10.

GRÁFICO 10: Distribuição de freqüência (\%) da temperatura média $\left({ }^{\circ} \mathrm{C}\right)$ dos pontos de amostragem no Parque Nacional Cavernas do Peruaçu (julho de 2003).

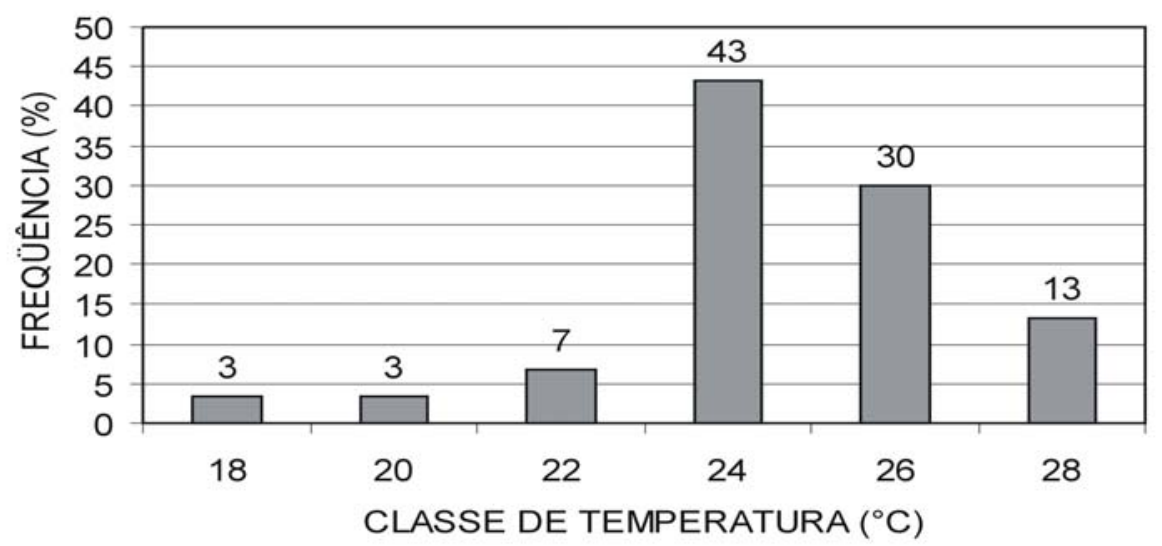

Fonte: Dados registrados em campo (julho de 2003).

Uma vez que foram identificadas a variação e a freqüência da temperatura média dos pontos de amostragem, é sabido que na escala local estas se configuram como um indicativo das características fisiográficas predominantes na área de estudo. 
Com base nisto, as temperaturas médias dos pontos amostrados foram projetadas sobre os controles climáticos que se manifestam nos aspectos do relevo representados neste trabalho tanto pela altimetria quanto pelas suas próprias formas.

Partindo do gradiente altimétrico da área de estudo entre 440 e 830 (aproximadamente), toda a série de dados registrada nos pontos de amostragem foi reagrupada, segundo os intervalos altimétricos identificados nos compartimentos geomorfológicos, permitindo evidenciar as variações térmicas em cada uma delas.

Assim, constatou-se que os pontos de amostragem localizados em cotas altimétricas mais baixas (entre 440 e 500 metros) apresentaram temperaturas mais elevadas, portanto, representando, como um todo, um ambiente mais aquecido.

Em contrapartida, os pontos de amostragem localizados em cotas mais altas (> 720 metros) evidenciaram a predominância de uma temperatura média mais amena (Gráfico 11).

GRÁFICO 11: Temperatura média $\left({ }^{\circ} \mathrm{C}\right)$ dos pontos de amostragem distribuída segundo as cotas altimétricas do Parque Nacional Cavernas do Peruaçu (julho de 2003).

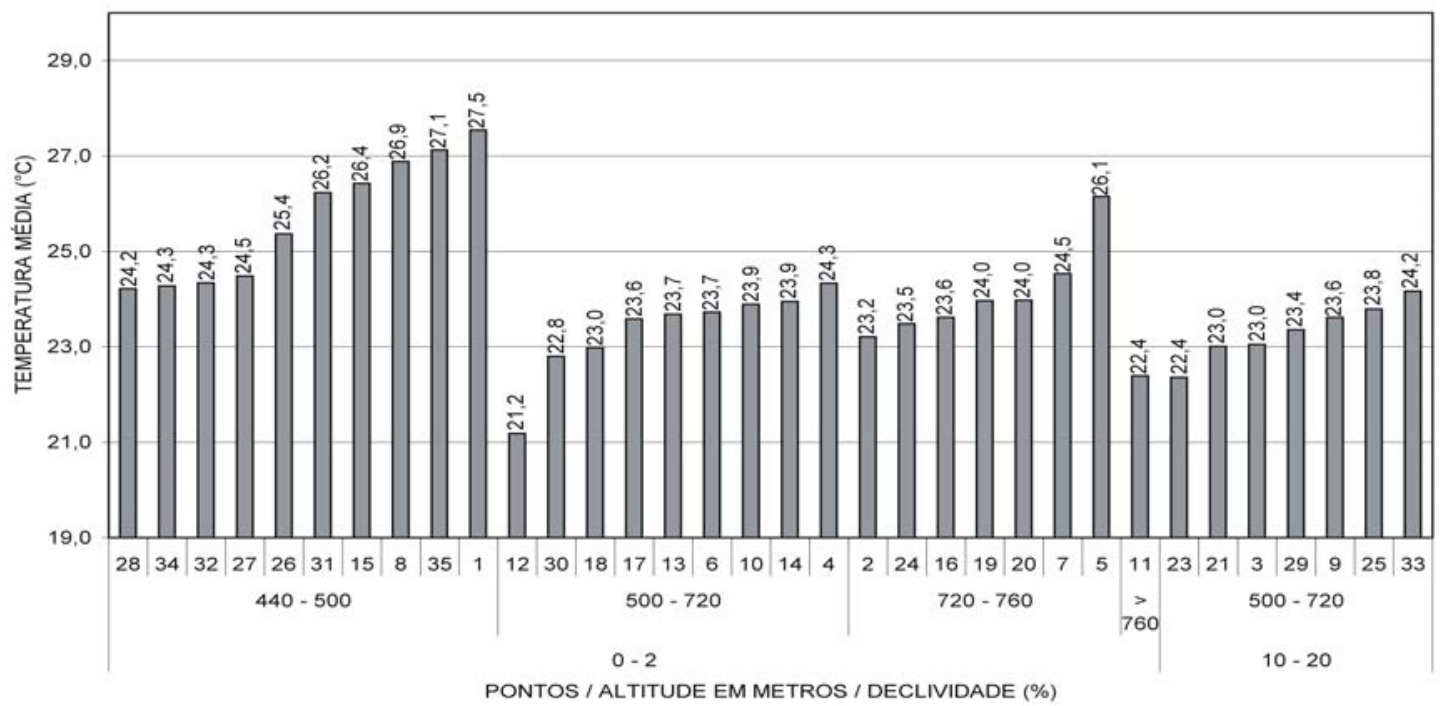

Fonte: Dados registrados em campo (julho de 2003). 
Dessa forma, considerando a variação de temperatura em relação às cotas altimétricas em que se distribuem os pontos de amostragem, é possível associar essa variação com os compartimentos geomorfológicos presentes na área de estudo, constatando as seguintes situações:

O Compartimento da Depressão do Rio São Francisco que apresenta uma altitude entre 440 e 500 metros configura-se como o mais aquecido (média de $\left.25,4^{\circ} \mathrm{C}\right)$;

No Compartimento do Planalto dos Gerais localizados em cotas altimétricas acima dos 760 metros, foram registradas as temperaturas mais baixas $\left(21,4^{\circ} \mathrm{C}\right)$;

Intermediário a estes dois compartimentos mais extremos, tem-se 0 Compartimento Carstificado (500 e 720 metros) e aquele da Zona de Transição (720 e 760 metros) onde as temperaturas médias foram de 23 e $23,2^{\circ} \mathrm{C}$, respectivamente.

$\mathrm{Na}$ Tabela 03, é apresentada a relação de pontos de amostragem em relação aos compartimentos geomorfológicos e suas respectivas temperaturas médias $\left({ }^{\circ} \mathrm{C}\right)$ do Parque Nacional Cavernas do Peruaçu.

Entretanto, com base nas observações realizadas em campo cabe ressalvar que as temperaturas elevadas do Compartimento da Depressão do Rio São Francisco estão relacionadas, primeiramente, aos padrões de uso e formas de ocupação do solo ali predominantes que, em linhas gerais, são caracterizadas pela intensa atividade pecuária que ocupam extensas áreas para pastagem, em substituição de áreas de cobertura vegetal natural.

Para o caso da Depressão do Rio São Francisco, ao se considerar o relevo como agente condicionador do clima local, este deve ser entendido como segundo plano através de uma perspectiva estrutural e escultural que tornaram sua ocupação favorável. 
TABELA 03: Relação dos compartimentos geomorfológicos do Parque Nacional Cavernas do Peruaçu e a temperatura média do ar $\left({ }^{\circ} \mathrm{C}\right)$ registrada nos pontos de amostragem ali localizados (julho de 2003).

\begin{tabular}{|c|c|c|}
\hline COMPARTIMENTO GEOMORFOLÓGICO & $\begin{array}{c}\text { PONTO DE } \\
\text { AMOSTRAGEM }\end{array}$ & $\begin{array}{l}\text { TEMPERATURA } \\
\text { MÉDIA }\left({ }^{\circ} \mathrm{C}\right)\end{array}$ \\
\hline \multirow{14}{*}{ COMPARTIMENTO CARSTIFICADO } & 03 & 23,3 \\
\hline & 04 & 23,2 \\
\hline & 06 & 23,7 \\
\hline & 09 & 22,8 \\
\hline & 12 & 21,2 \\
\hline & 13 & 23,7 \\
\hline & 14 & 23,8 \\
\hline & 17 & 25,0 \\
\hline & 18 & 14,9 \\
\hline & 21 & 23,0 \\
\hline & 23 & 18,2 \\
\hline & 25 & 23,3 \\
\hline & 30 & 22,8 \\
\hline & 33 & 24,2 \\
\hline \multicolumn{2}{|l|}{ MÉDIA } & 23,0 \\
\hline \multirow{10}{*}{$\begin{array}{l}\text { COMPARTIMENTO DA DEPRESSÃO DO RIO SÃO } \\
\text { FRANCISCO }\end{array}$} & 01 & 24,7 \\
\hline & 08 & 26,7 \\
\hline & 15 & 26,3 \\
\hline & 26 & 26,4 \\
\hline & 27 & 24,7 \\
\hline & 28 & 24,2 \\
\hline & 31 & 24,7 \\
\hline & 32 & 24,3 \\
\hline & 34 & 24,7 \\
\hline & 35 & 27,1 \\
\hline \multicolumn{2}{|l|}{ MÉDIA } & 25,4 \\
\hline \multirow{5}{*}{ COMPARTIMENTO DA ZONA DE TRANSIÇÃO } & 02 & 23,2 \\
\hline & 16 & 23,0 \\
\hline & 19 & 22,9 \\
\hline & 20 & 23,1 \\
\hline & 24 & 24,3 \\
\hline \multicolumn{2}{|l|}{ MÉDIA } & 23,2 \\
\hline COMPARTIMENTO DO PLANALTO DOS GERAIS & 11 & 21,4 \\
\hline \multicolumn{2}{|l|}{ MÉDIA } & 21,4 \\
\hline \multicolumn{2}{|l|}{ MÉDIA TOTAL } & 23,8 \\
\hline
\end{tabular}

Fonte: Dados registrados em campo (julho de 2003).

Visando um melhor entendimento da temperatura média registrada em cada compartimento geomorfológico, considerou-se a freqüência de ocorrência dos valores de temperatura em relação a esses compartimentos quando foram observadas e destacadas as seguintes características:

- O Compartimento Carstificado foi o ambiente que mais apresentou variação térmica ao longo do período considerado (julho de 2003). Entretanto, as temperaturas que tiveram um número maior de registros estão em torno dos $24^{\circ} \mathrm{C}$ representando, aliás, a temperatura mais 
recorrente $(30 \%)$ entre todos os compartimentos geomorfológicos do Parque Nacional Cavernas do Peruaçu;

- No Compartimento da Depressão do Rio São Francisco, as temperaturas próximas de $25^{\circ} \mathrm{C}$ foram as mais representativas tanto na própria depressão sanfranciscana como entre os demais;

- O Compartimento da Zona de Transição apresentou uma variação variações entre 23 e $24^{\circ} \mathrm{C}$ distribuídas de forma, praticamente homogênea;

- No Compartimento do Planalto dos Gerais, a temperatura predominante está em torno dos $22^{\circ} \mathrm{C}$ (Gráfico 12).

Após 0 entendimento da temperatura em relação às características geomorfológicas que atuam como agente de suporte das manifestações fisiográficas que envolvem as comunidades vegetais e humanas sobre da área de estudo, a seguir, as temperaturas médias dos pontos de amostragem serão consideradas na perspectiva das unidades de paisagens (Geofácies e Geossistemas) definidas neste trabalho, composta por elementos fitológicos e antrópicos representados pelas formações vegetais e ambientes antropogênicos, distintamente.

GRÁFICO 12: Distribuição de freqüência (\%) da temperatura média $\left({ }^{\circ} \mathrm{C}\right)$ dos pontos de amostragem segundo os compartimentos geomorfológicos do Parque Nacional Cavernas do Peruaçu (julho de 2003).

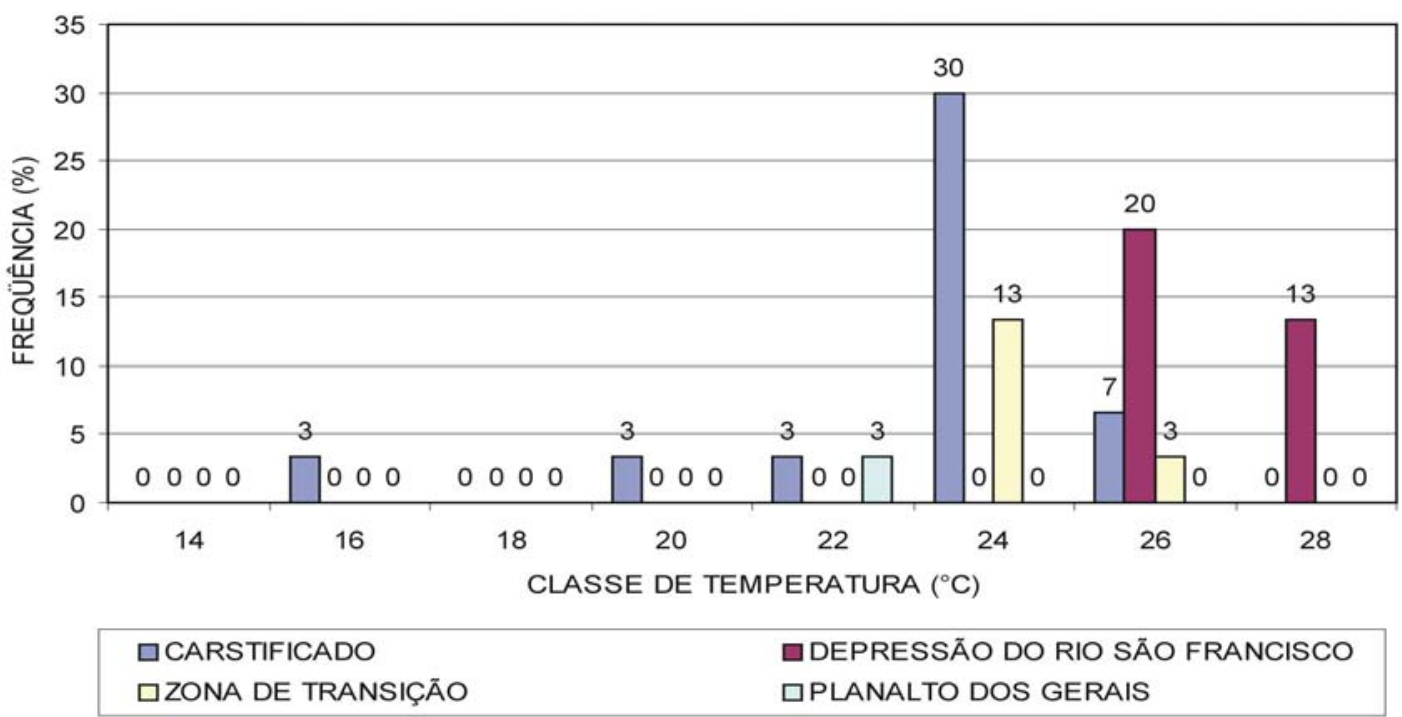

Fonte: Dados registrados em campo (julho de 2003). 
Os elementos que compõem uma unidade de paisagem na escala de detalhe das geofácies, como é o caso das Geofácies da Formação Florestal, Savânica, Savânica Estépica e Ambiente Antropogênico, atuam determinantemente nas características climáticas de um determinado ambiente na escala compatível.

Nesta perspectiva, as temperaturas médias dos pontos de amostragem foram sobrepostos a estes elementos constituintes da paisagem na escala das geofácies, de onde foram observadas as seguintes características:

- Nas Geofácies dos Ambientes Antropizados, as temperaturas médias obtidas variam entre 20 e $28^{\circ} \mathrm{C}$, com temperaturas mais freqüentes variando entre 24 e $25^{\circ} \mathrm{C}$, com destaque para as temperaturas em torno $\operatorname{dos} 25^{\circ} \mathrm{C}$;

- Nas Geofácies da Formação Florestal, as temperaturas variam entre 14 e $25^{\circ} \mathrm{C}$, sendo que as temperaturas médias mais freqüentes estão em torno dos $23^{\circ} \mathrm{C}$;

- Nas Geofácies da Formação Savânica as temperaturas médias totais variaram entre 21 e $23^{\circ} \mathrm{C}$;

- Nas Geofácies da Formação Savânica Estépica foi a segunda unidade de paisagem mais quente, onde as temperaturas médias totais ficaram entre 24 e $25^{\circ} \mathrm{C}$ (Gráfico 13);

GRÁFICO 13: Temperatura média $\left({ }^{\circ} \mathrm{C}\right)$ registrada nas unidades de paisagem das geofácies do Parque Nacional Cavernas do Peruaçu (julho de 2003).

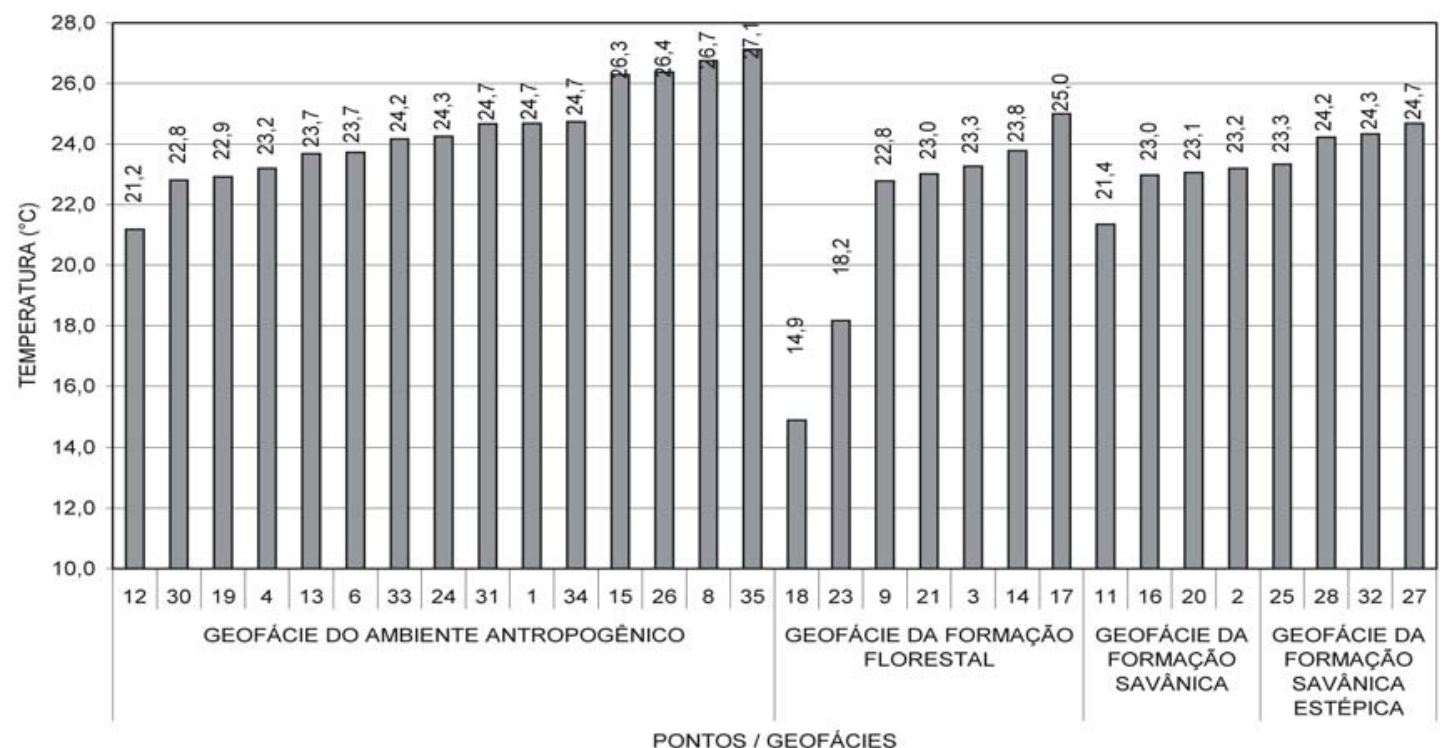


Fonte: Dados registrados em campo (julho de 2003).

Essas temperaturas mais elevadas na Geofácie do Ambiente Antropogênico estão associadas às áreas de pastagem em detrimento das reduzidas áreas com cobertura vegetal, além da existência de núcleos populacionais como é o caso, por exemplo, do Fabião I e Fabião II e até mesmo de Itacarambí, configurada como uma área urbana.

Notadamente, as áreas marcadas pela presença humana tendem a se transformar em ambientes instáveis do ponto de vista climático, refletindo no aumento das amplitudes térmicas. Em linhas gerais, a amplitude térmica de um mesmo ambiente poder ser indicativa do grau de semelhança entre os controles climáticos atuantes ali.

Diferentemente às áreas antropizadas, aquelas recobertas por algum tipo de vegetação arbórea, como a encontrada em parte do Parque Nacional Cavernas do Peruaçu apresenta um padrão fisionômico favorável à manutenção de climas sem grandes variações, mantendo temperaturas mais amenas.

Então, o que se vê é um gradiente positivo de temperatura proporcionalmente inverso à diminuição do porte da vegetação e superfície foliar que, no cenário fitológico da área de estudo está associado ao regime de caducifolia típico da floresta estacional impondo uma fisionomia mais ressecada e aberta favorável à penetração mais acentuada da radiação solar, perda de umidade na escala microclimática e ressecamento do solo, entre outros fatores, aproximando-se assim das condições térmicas de um ambiente antropizado.

Considerando as informações sobre a variação da temperatura em cada uma das Geofácies apresentadas acima, a seguir a temperatura será analisada tendo como referência fisiográfica as unidades de paisagens dos Geossistemas qualificadas neste trabalho.

Em linhas gerais, as características climáticas evidenciadas na área de estudo, apontaram o Geossistema da Depressão do Rio São Francisco como a unidade de paisagem mais aquecida dentre todas decorrente das condições atuais de intenso uso e ocupação do solo observadas na área mapeada.

No Geossistema da Depressão do Rio São Francisco, em julho de 2003 a temperatura média dos pontos amostrais foi de $25,4^{\circ} \mathrm{C}$, com média mínima de $24,2^{\circ} \mathrm{C}$ e média máxima de $27,1^{\circ} \mathrm{C}$. 
No Geossistema da Serras da Mãe Joana e do Cardoso de Minas a temperatura média foi de $22,5^{\circ} \mathrm{C}$ (médias mínima e máxima de 14,9 e $24,2^{\circ} \mathrm{C}$, respectivamente), enquanto que no Geossistema do Planalto do Rio São Francisco, a temperatura média para julho de 2003 foi de $23,3^{\circ} \mathrm{C}$, tendo sido registradas médias mínima e máxima de 21,2 e $25^{\circ} \mathrm{C}$, respectivamente (Gráfico 14).

Considerando as informações sobre as temperaturas obtidas nos pontos de amostragem e unidades de paisagem enquadradas na escala das geofácies e dos geossistemas, a seguir é apresentada a distribuição dos valores médios de temperatura sobre a área mapeada no mês de julho de 2003, com destaque para o Parque Nacional Cavernas do Peruaçu (Figura 37).

GRÁFICO 14: Temperatura média $\left({ }^{\circ} \mathrm{C}\right)$ dos geossistemas do Parque Nacional Cavernas do Peruaçu (julho de 2003).

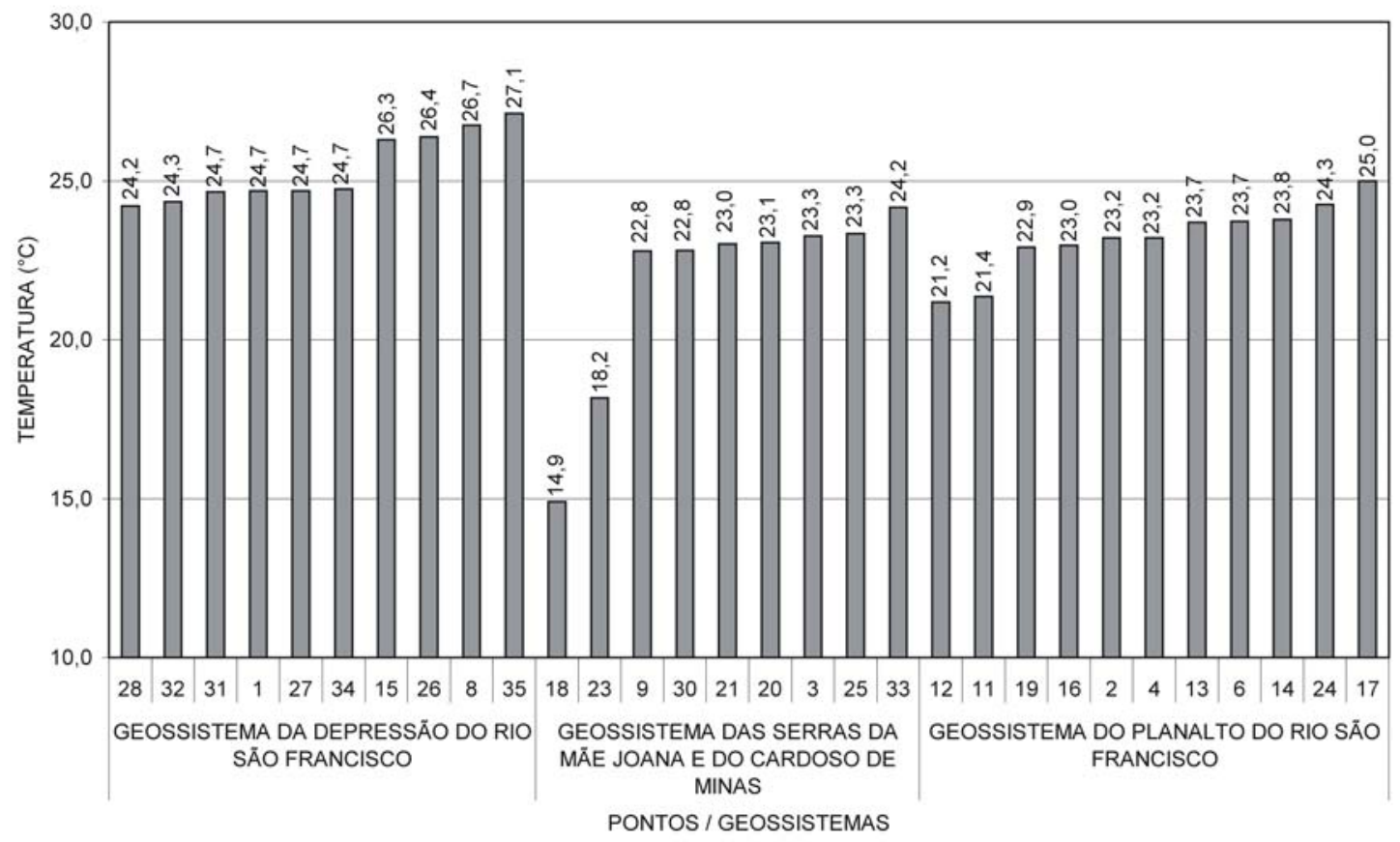

Fonte: Dados registrados em campo (julho de 2003).

$\mathrm{Na}$ área mapeada, a porção pertencente ao compartimento geomorfológico da Depressão do Rio São Francisco, as temperaturas médias oscilaram entre 25 e $28^{\circ} \mathrm{C}$.

Dentro deste intervalo, as temperaturas mais elevadas foram registradas sobre as áreas reconhecidamente ocupadas por atividades antrópicas próximas ao 
rio São Francisco até os limites leste do Parque Nacional Cavernas do Peruaçu.

Também dentro deste intervalo, as temperaturas médias mais amenas deste compartimento geomorfológico oscilaram sobre o trecho inserido nos limites da área de estudo, onde as condições de preservação são melhores, mantendo áreas menos alteradas pela ação antrópica local.

Já na porção da área de estudo pertencente aos compartimentos geomorfológicos "carstificado" e de "transição", tal qual foram descritos, as temperaturas médias oscilam entre 24 e $26^{\circ} \mathrm{C}$ distribuída numa faixa orientada no sentido sudoeste - nordeste, acompanhando praticamente todo o território do Parque Nacional Cavernas do Peruaçu.

Inserida nesta faixa, observa-se também, que os trechos de terra ainda ocupados pelas comunidades remanescentes (ver Pontos $n^{\circ}$. 10, 12 e 13 no mapa de pontos visitados - Capítulo 4) apresentaram temperaturas acima dos $26^{\circ} \mathrm{C}$, enquanto que áreas ali próximas onde predomina a formação florestal distribuídas sobre um relevo formado por vales e serras, as temperaturas oscilaram entre 16 e $24^{\circ} \mathrm{C}$, formando pequenas zonas de frescor (Pontos $\mathrm{n}^{\circ}$. 17, 18, 23 e 29). 


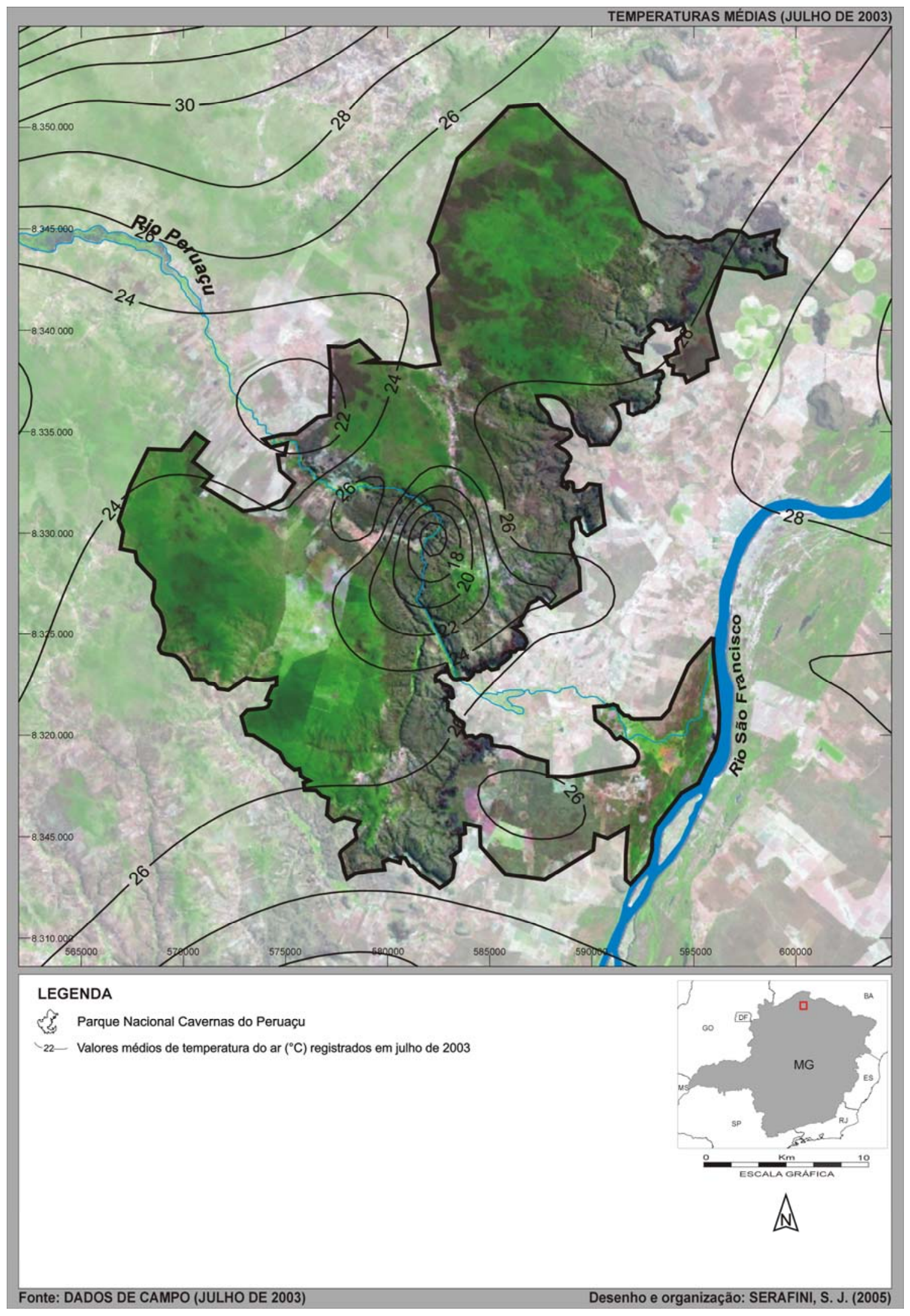

FIGURA 37: Temperatura média $\left({ }^{\circ} \mathrm{C}\right)$ no Parque Nacional Cavernas do Peruaçu no mês de julho de 2003. 


\subsubsection{A UMIDADE RELATIVA DO AR}

A umidade relativa do ar, entre outros agentes, é controlada pela temperatura, tendendo a ser mais baixa nos ambientes onde a temperatura apresenta-se mais elevada, portanto, um ambiente com maior capacidade evaporativa da água.

Com base nisto, considerando os dados coletados no mês de julho de 2003, foi registrada para toda a área de estudo uma umidade relativa do ar média de $50 \%$, com a mínima e a máxima absolutas de $22 \%$ (Ponto $\mathrm{n}^{\circ} .26$ ) e $98 \%$ (Ponto $\left.\mathrm{n}^{\circ} .11\right)$, respectivamente.

Comparando a umidade relativa do ar média (50\%) deste período com a normal climatológica das estações meteorológicas do INMET mais próximas à área de estudo (Espinosa, Formosa, Monte Azul, Montes Claros e Posse) (Tabela 04), pode-se observar que o Parque Nacional Cavernas do Peruaçu apresentou uma taxa de umidade relativa do ar mais baixa da média registrada entre 1961 e 1990 (55\%).

TABELA 04: Umidade relativa (\%) do ar média entre 1961 e 1990 no mês de julho nas estações meteorológicas do INMET circundantes ao Parque Nacional Cavernas do Peruaçu e umidade relativa do ar média desta Unidade de Conservação em julho de 2003.

\begin{tabular}{l|l|c}
\hline \multicolumn{1}{c|}{$\begin{array}{c}\text { PERÍODO } \\
\text { CONSIDERADO }\end{array}$} & \multicolumn{1}{|c}{ NOME } & $\begin{array}{c}\text { UMIDADE RELATIVA MÉDIA } \\
(\%)\end{array}$ \\
\hline \multirow{4}{*}{$1961-1990$} & ESPINOSA & 54 \\
\cline { 2 - 3 } & FORMOSA & 58 \\
\cline { 2 - 3 } & MONTE AZUL & 55 \\
\cline { 2 - 3 } & MONTES CLAROS & 59 \\
\cline { 2 - 3 } & POSSE & 52 \\
\cline { 2 - 3 } & MÉDIA (1961 - 1990) & 55 \\
\hline \multirow{2}{*}{ JULHO DE 2003 } & $\begin{array}{l}\text { PARQUE NACIONAL CAVERNAS } \\
\text { DO PERUAÇU }\end{array}$ & 50 \\
\hline
\end{tabular}

Fonte: Dados registrados em campo (julho de 2003).

Esse desvio da média higrométrica local em relação à climatologia entre 1961 e 1990 associado ao desvio dos valores médios de temperatura, constata-se que 
o Parque Nacional Cavernas do Peruaçu no mês de julho de 2003, configurouse como um ambiente mais seco do que aquele registrado no período climatológico.

Comprovando isto, segundo o INPE (op. cit,, 2003), neste mesmo período foram detectados 19.481 focos de queimadas na região central e norte do País, contra 10.770 detectados no mesmo período do ano anterior (2002).

Por conta desse aumento algumas Unidades de Conservação entraram em estado de alerta inicial por apresentarem focos no seu interior ou proximidades, conforme monitoramento do IBAMA.

Entre elas estava o Parque Nacional Cavernas do Peruaçu quando foram registradas taxas de umidade relativa do ar mais freqüente em torno dos $40 \%$, representando $29 \%$ de toda a temperatura, enquanto que situações com maior taxa de umidade relativa, apresentaram uma freqüência relativa decrescente proporcionalmente inversa ao aumento higrométrico (Gráfico 15).

GRÁFICO 15: Distribuição de freqüência (\%) da umidade relativa do ar (\%) registrada no Parque Nacional Cavernas do Peruaçu (julho de 2003).

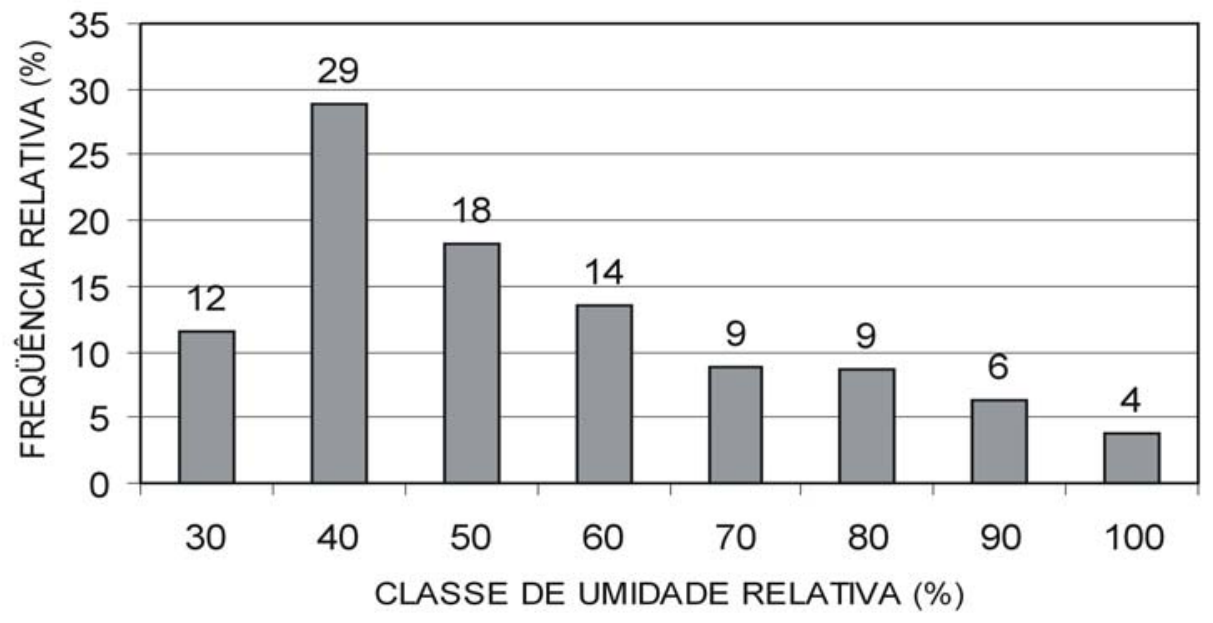

Fonte: Dados registrados em campo (julho de 2003).

Identificando a freqüência de umidade relativa do ar média dos pontos de amostragem verifica-se que, a principal faixa de variação higrométrica esteve em torno dos $50 \%$, que representa $43 \%$ de toda a amostragem média dos pontos (Gráfico 16). 
GRÁFICO 16: Distribuição de freqüência (\%) da umidade relativa do ar média (\%) dos pontos de amostragem no Parque Nacional Cavernas do Peruaçu (julho de 2003).

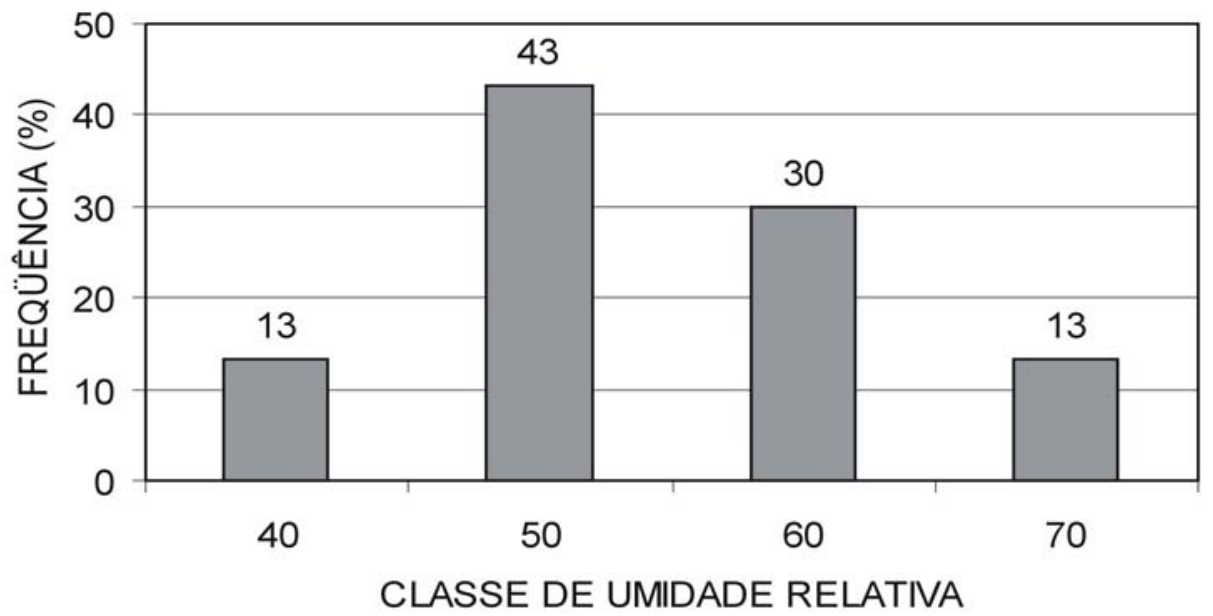

Fonte: Dados registrados em campo (julho de 2003).

Reagrupando os pontos de amostragem segundo as cotas altimétricas com o objetivo de identificar variações de umidade relativa do ar, foram verificados os seguintes aspectos:

Coincidindo com a variação térmica evidenciada em relação aos diferentes níveis altimétricos da área de estudo, de modo geral a umidade relativa do ar apresentou variação proporcionalmente inversa à temperatura.

Nesta perspectiva, considerando a umidade relativa do ar média de cada ponto de amostragem e sua altitude, pode-se observar que aqueles pontos localizados em cotas superiores a 500 metros apresentaram uma taxa média de umidade mais elevada, enquanto que aqueles pontos localizados entre 440 e 500 metros apresentaram uma condição de umidade mais deficiente configurando-se, portanto, num ambiente mais seco (Gráfico 17).

Como foi observado em relação à temperatura, cabe observar que os baixos valores de umidade relativa do ar registrados no compartimento geomorfológico da Depressão do Rio São Francisco estão associados primeiramente aos padrões de uso e formas de ocupação daquele espaço onde predominam áreas de pastagem. 
GRÁFICO 17: Umidade relativa do ar média (\%) dos pontos de amostragem distribuída segundo as cotas altimétricas do Parque Nacional Cavernas do Peruaçu (julho de 2003).

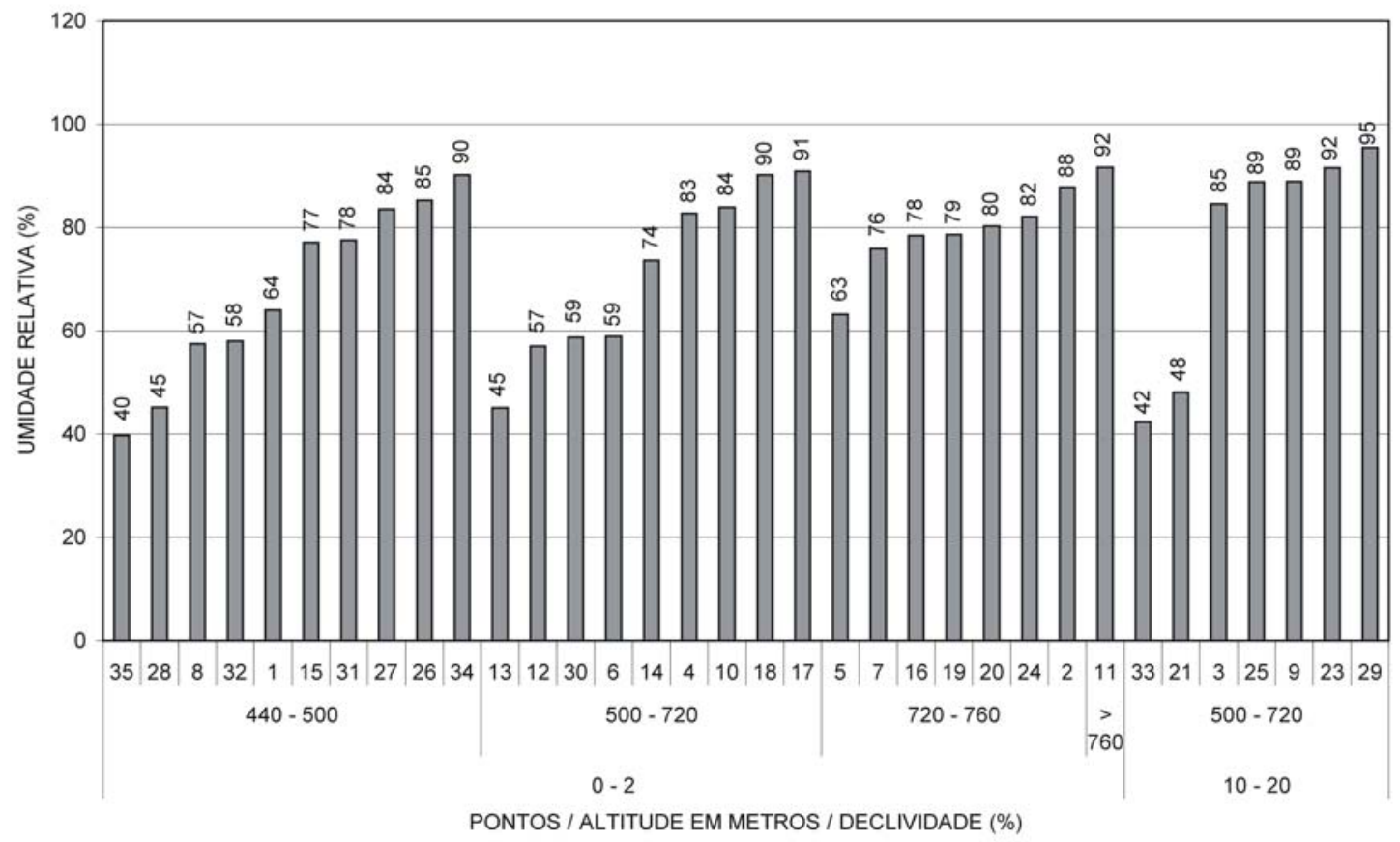

Fonte: Dados registrados em campo (julho de 2003).

Associando a altimetria com os compartimentos geomorfológicos do Parque Nacional Cavernas do Peruaçu sobre os quais são marcadas as variações da temperatura média, estes mesmos controles climáticos impõem variações nas condições higrométricas nestes mesmos ambientes que se apresentam com as seguintes características registradas em julho de 2003, mostradas na Tabela 05.

Entre eles, destaca-se o Compartimento da Depressão do Rio São Francisco que, além de mais aquecido, também apresentou a menor taxa de umidade relativa do ar, configurando-se como o mais seco.

Em condição oposta, deve ser destacado também o Compartimento do Planalto dos Gerais que se configurou como o ambiente com temperaturas mais baixas em relação aos outros compartimentos e a maior taxa de umidade relativa do ar. 
TABELA 05: Relação dos compartimentos geomorfológicos do Parque Nacional Cavernas do Peruaçu e a umidade relativa média do ar $\left({ }^{\circ} \mathrm{C}\right)$ registrada nos pontos de amostragem ali localizados (julho de 2003).

\begin{tabular}{|c|c|c|}
\hline COMPARTIMENTO GEOMORFOLÓGICO & $\begin{array}{l}\text { PONTO DE } \\
\text { AMOSTRAGEM }\end{array}$ & $\begin{array}{c}\text { UMIDADE } \\
\text { RELATIVA DO } \\
\text { AR MÉDIA (\%) }\end{array}$ \\
\hline \multirow{14}{*}{ COMPARTIMENTO CARSTIFICADO } & 03 & 60 \\
\hline & 04 & 48 \\
\hline & 06 & 59 \\
\hline & 09 & 45 \\
\hline & 12 & 57 \\
\hline & 13 & 45 \\
\hline & 14 & 51 \\
\hline & 17 & 49 \\
\hline & 18 & 70 \\
\hline & 21 & 48 \\
\hline & 23 & 62 \\
\hline & 25 & 49 \\
\hline & 30 & 59 \\
\hline & 33 & 42 \\
\hline \multicolumn{2}{|l|}{ MÉDIA } & 52 \\
\hline \multirow{10}{*}{$\begin{array}{l}\text { COMPARTIMENTO DA DEPRESSÃO DO RIO SÃO } \\
\text { FRANCISCO }\end{array}$} & 01 & 47 \\
\hline & 08 & 37 \\
\hline & 15 & 39 \\
\hline & 26 & 44 \\
\hline & 27 & 46 \\
\hline & 28 & 45 \\
\hline & 31 & 44 \\
\hline & 32 & 58 \\
\hline & 34 & 53 \\
\hline & 35 & 40 \\
\hline \multicolumn{2}{|l|}{ MÉDIA } & 45 \\
\hline \multirow{5}{*}{ COMPARTIMENTO DA ZONA DE TRANSIÇÃO } & 02 & 53 \\
\hline & 16 & 49 \\
\hline & 19 & 53 \\
\hline & 20 & 55 \\
\hline & 24 & 38 \\
\hline \multicolumn{2}{|l|}{ MÉDIA } & 50 \\
\hline COMPARTIMENTO DO PLANALTO DOS GERAIS & 11 & 65 \\
\hline \multicolumn{2}{|l|}{ MÉDIA } & 65 \\
\hline \multicolumn{2}{|l|}{ MÉDIA TOTAL } & 50 \\
\hline
\end{tabular}

Fonte: Dados registrados em campo (julho de 2003).

Visando um melhor entendimento da umidade relativa do ar média registrada em cada compartimento geomorfológico, considerou-se a freqüência de ocorrência desses valores ali registrados, quando foram observadas as seguintes características:

As taxas de umidade relativa do ar mais recorrentes do Compartimento Geomorfológico da Depressão do Rio São Francisco estão concentradas em torno dos $40 \%$, seguidos pelo registro de taxas menos representativas em torno dos $30 \%$ e dos $50 \%$; 
No âmbito do Compartimento Carstificado os valores de umidade relativa do ar mais recorrentes estão na faixa dos $50 \%$, e freqüências menores registradas entre 60 e $70 \%$;

$\mathrm{Na}$ Zona de Transição as principais taxas de umidade relativa do ar foram registradas na faixa dos $60 \%$, apresentando variações para atmosferas mais secas, variando entre 40 e $50 \%$; e,

O valor de umidade relativa do ar correspondente ao Compartimento do Planalto dos Gerais encontra-se em apenas uma classe (70\%), provavelmente associado à pequena quantidade de registros ali obtidos (Gráfico 18).

Considerado como pano de fundo os aspectos geomorfológicos da área de estudo, onde se manifestam os fenômenos de ocupação das comunidades vegetais e humanas a seguir, as características da umidade relativa registrada nos pontos de amostragem serão consideradas na perspectiva das unidades de paisagens (Geofácies e Geossistemas) definidas neste trabalho, composta pelos elementos fitológicos e antrópicos representados pelas formações vegetais e ambientes antropogênicos, distintamente.

GRÁFICO 18: Distribuição de freqüência (\%) da umidade relativa média do ar (\%) dos pontos de amostragem segundo os compartimentos geomorfológicos do Parque Nacional Cavernas do Peruaçu (julho de 2003).

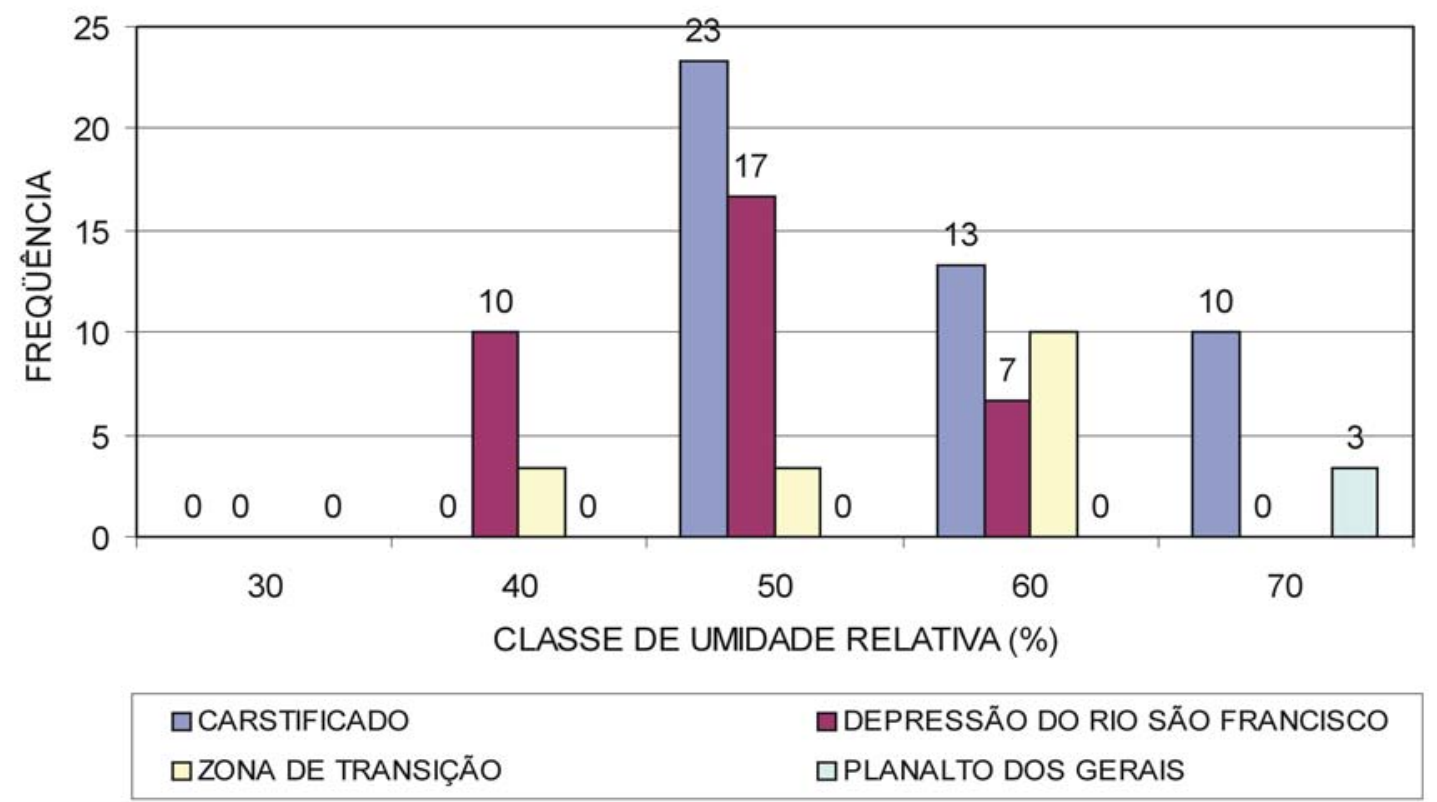

Fonte: Dados registrados em campo (julho de 2003). 
Sobrepondo os valores médios de umidade relativa do ar sobre as Geofácies da Formação Florestal, Savânica, Savânica Estépica e Ambiente Antropogênico verifica-se que os ambientes antropizados mostraram-se mais áridos, registrando uma taxa de umidade relativa de $40 \%$, enquanto que os ambientes florestados, de modo geral, registraram taxas superiores a $50 \%$, com destaque para a Formação Savânica que se configurou como o ambiente mais úmido entre todos.

Com base nos valores higrométricos médios registrados no âmbito das geofácies, foram observadas as seguintes características:

- A Geofácie do Ambiente Antropogênico apresentou-se como o ambiente mais seco dentre todos os outros;

- A Geofácie da Formação Florestal apresentou-se como o ambiente mais úmido em relação aos demais; e,

- As Geofácies da Formação Savânica e Savânica Estépica apresentaram características higrométricas muito semelhantes (Gráfico 19)

GRÁFICO 19: Umidade relativa média do ar (\%) registrada nas unidades de paisagem das geofácies do Parque Nacional Cavernas do Peruaçu (julho de 2003).

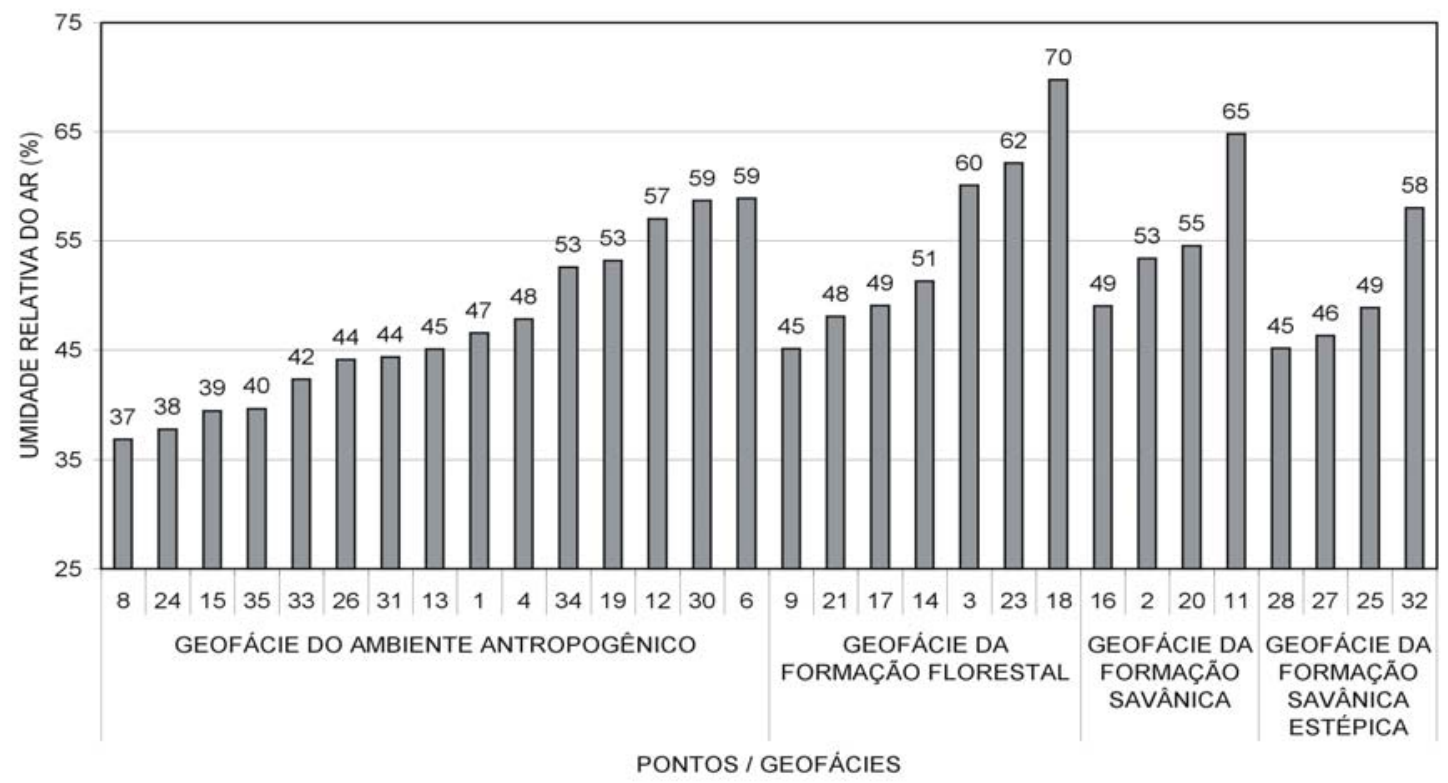

Fonte: Dados registrados em campo (julho de 2003). 
Projetando as características higrométricas sobre as unidades de paisagem enquadradas na escala dos geossistemas, destaca-se o da Depressão do Rio São Francisco que registrou umidade relativa do ar de $45 \%$.

Em linhas gerais, com base nos dados de campo, foi observado que o Geossistema da Depressão do Rio São Francisco configurou-se como um ambiente com baixa umidade relativa do ar (45\%, com médias mínima e máxima de 37 e $58 \%$, respectivamente) se comparada com os outros dois geossistemas.

No Geossistema da Serras da Mãe Joana e do Cardoso de Minas a umidade relativa do ar média foi de 52\% (médias mínima e máxima de 42 e $70 \%$, respectivamente) enquanto que, no Geossistema do Planalto do Rio São Francisco, a umidade relativa do ar foi de 51\% (médias mínima e máxima de 38 e $65 \%$, respectivamente) como mostra o Gráfico 20.

GRÁFICO 20: Umidade relativa média do ar (\%) dos geossistemas do Parque Nacional Cavernas do Peruaçu (julho de 2003).

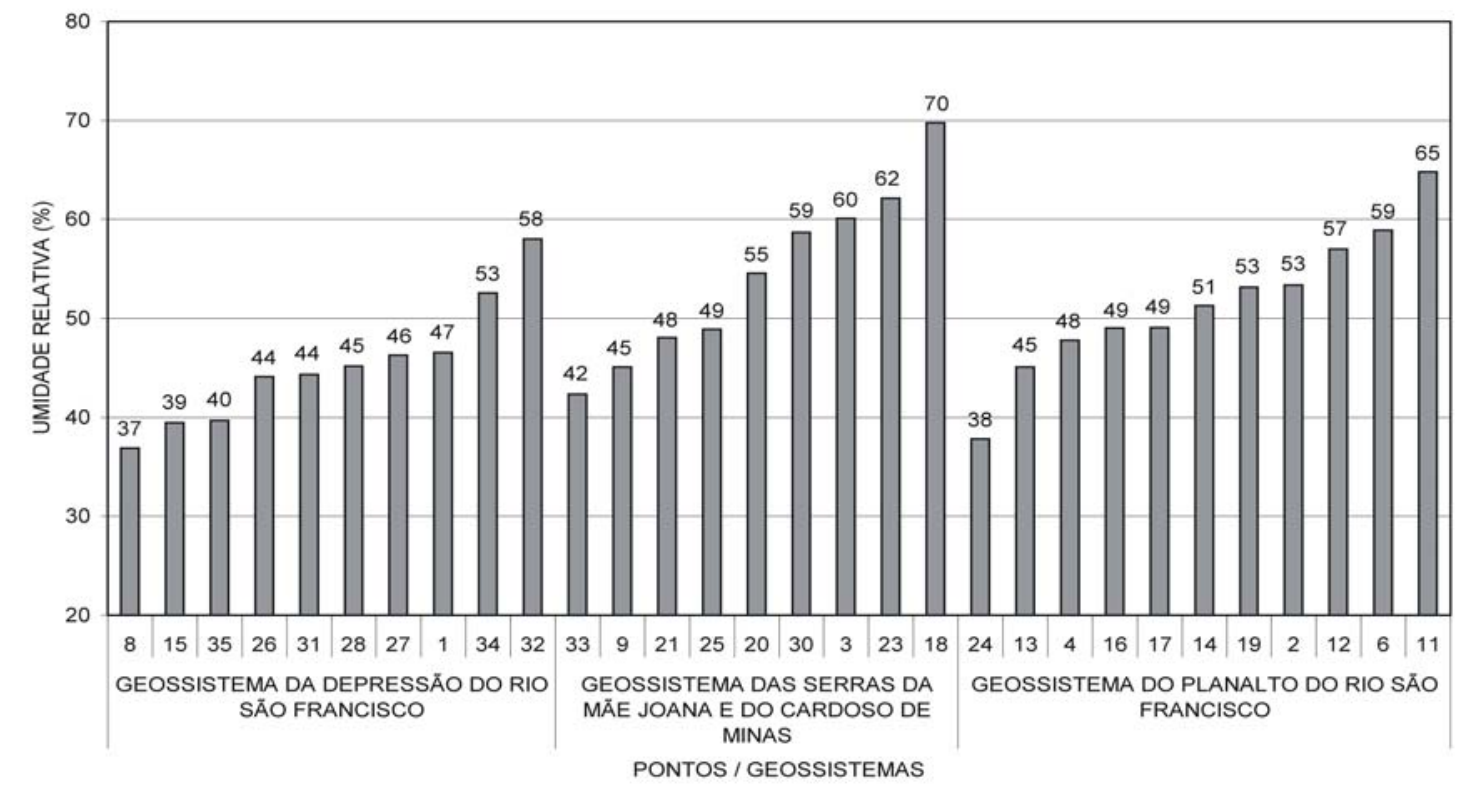

Fonte: Dados registrados em campo (julho de 2003).

Considerando as informações sobre a variação higrométrica dos pontos de amostragem pertencentes às unidades de paisagem enquadradas na escala das geofácies e dos geossistemas, a seguir é apresentada a distribuição dos valores médios de umidade relativa do ar sobre a área mapeada no mês de 
julho de 2003, com destaque para o Parque Nacional Cavernas do Peruaçu (Figura 38).

As condições higrométricas registradas em julho de 2003, praticamente são inversamente proporcionais à variação térmica para o mesmo período, apresentando, de modo geral, atmosfera mais seca sobre áreas que com temperaturas mais elevadas.

Assim, na área mapeada, foi observado no compartimento geomorfológico da Depressão do Rio São Francisco, a existência de uma atmosfera seca, com umidade variando na faixa dos $40 \%$ em decorrência da extensividade da atividade pecuária predominante naquela porção, em detrimento da supressão da vegetação nativa que ora já foi identificada como uma componente efetiva na variação climática na escala local.

Sobre a porção planaltina da área de estudo, onde são encontradas áreas mais extensas de vegetação natural e pouca alteração causada pela ocupação humana, a umidade relativa média oscilou entre 40 e $50 \%$.

Sobre aquele trecho do Parque Nacional Cavernas do Peruaçu onde predomina a formação florestal e relevos de vales e serras, identificados como pequenas zonas de frescor (Pontos $n^{\circ}$. 17, 18, 23 e 29), a variação higrométrica apresentou um pequeno aumento (entre 50 e 60\%), mas que no âmbito de toda a área de estudo, configurou-se como o mais úmido considerando as condições térmicas do período analisado. 


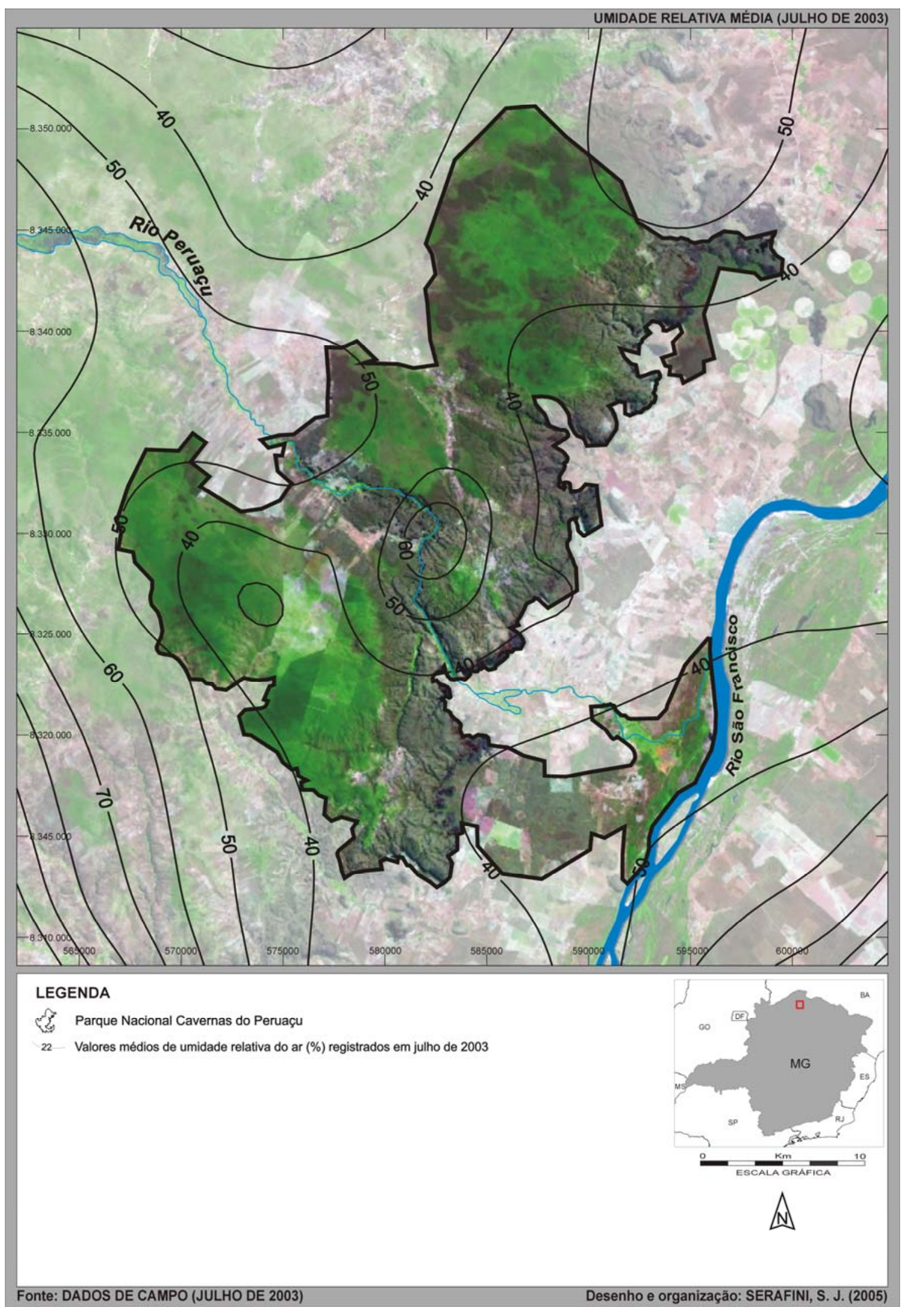

FIGURA 38: Umidade relativa média do ar (\%) do Parque Nacional Cavernas do Peruaçu no mês de julho de 2003. 


\subsection{EM JANEIRO DE 2004}

\subsubsection{A CIRCULAÇÃO ATMOSFÉRICA E TIPOS DE TEMPO ASSOCIADOS NA ESCALA DIÁRIA}

O mês de janeiro, segundo o INPE (op. cit., 2004) foi marcado pela passagem de três sistemas frontais que, de modo geral, ao atingirem a porção sul do País, deslocaram-se para o oceano atlântico. Foram registradas, também, três ocorrência dos episódios de ZCAS pronunciado sobre o território mineiro.

\subsubsection{Entre os dias 01 e 03 de janeiro de 2004 .}

Antecedendo essa dinâmica registrada em janeiro de 2004, no final de dezembro de 2003, um sistema frontal deslocara-se do interior do Paraná em direção ao norte da Bahia, passando sobre Minas Gerais entre os dias $1^{\circ}$ e 3 de janeiro de 2004, mais especificamente sobre as localidades de Patos de Minas e Pirapora (Figura 39), configurando-se como a primeira frente fria do ano, deixando as temperaturas nos primeiros três dias do mês com valores relativamente baixos para esta época do ano.

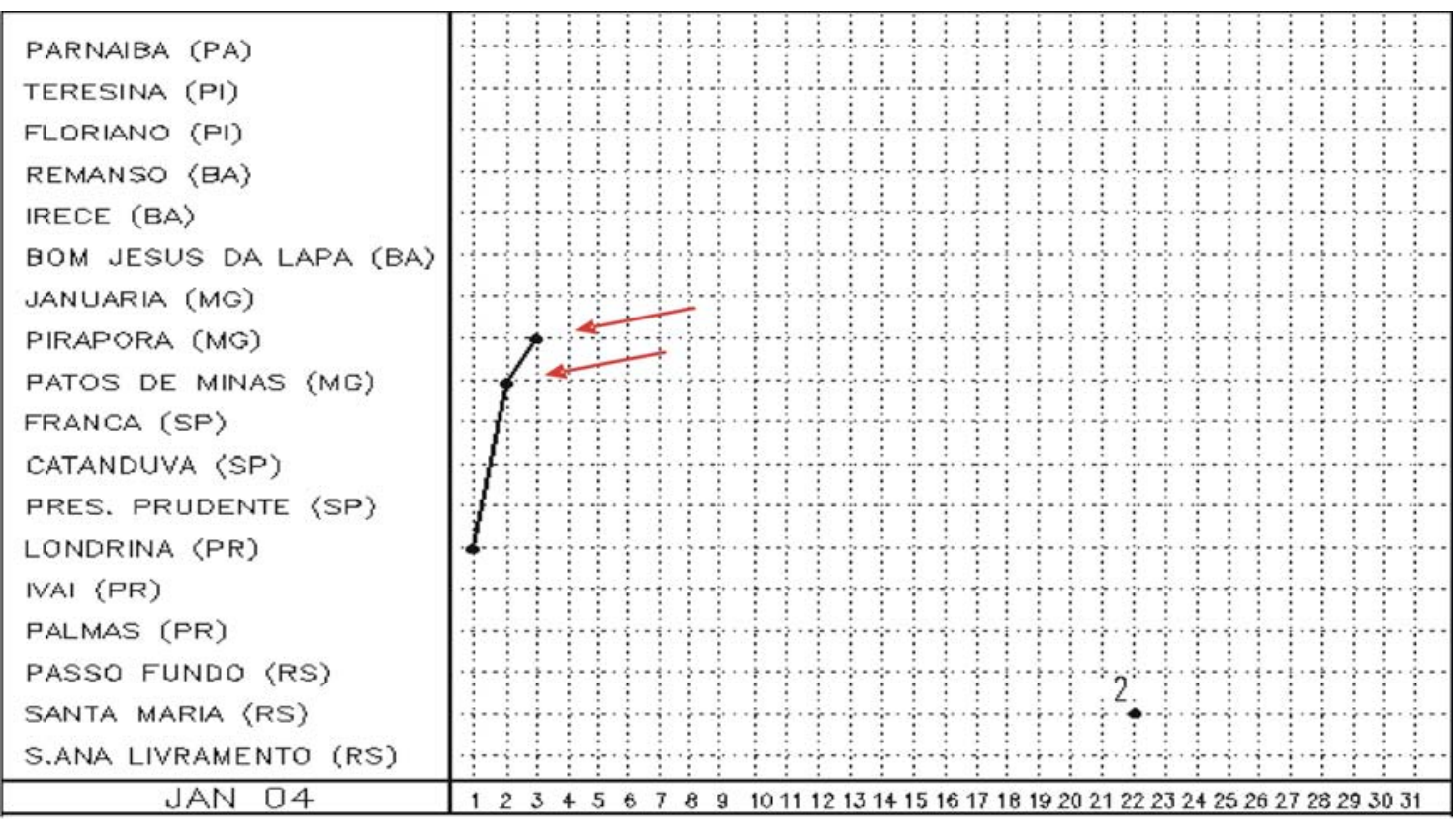

Fonte: INPE, 2004

FIGURA 39: Registro da passagem da terceira frente fria sobre o território mineiro, próximo a Patos de Minas e Pirapora (indicada pelas setas vermelhas) entre os dias 2 e 3 de janeiro de 2004. 


\subsubsection{Entre os dias 04 e 10 de janeiro de 2004 .}

Chegando à Bahia o primeiro sistema frontal do ano permaneceu estacionário, no período de 04 a 07, favorecendo a configuração do primeiro episódio de ZCAS de 2004 ocorrido entre os dias 02 e 06 de janeiro.

Neste período, a banda de nebulosidade produzida por esta zona de convergência estendeu-se por quase toda a porção centro norte do Brasil, cobrindo parte das Regiões Norte, Centro-Oeste e Sudeste, estendendo-se, também para o Oceano Atlântico na altura do litoral do Espírito Santo, como pode ser observado na Figura 40.

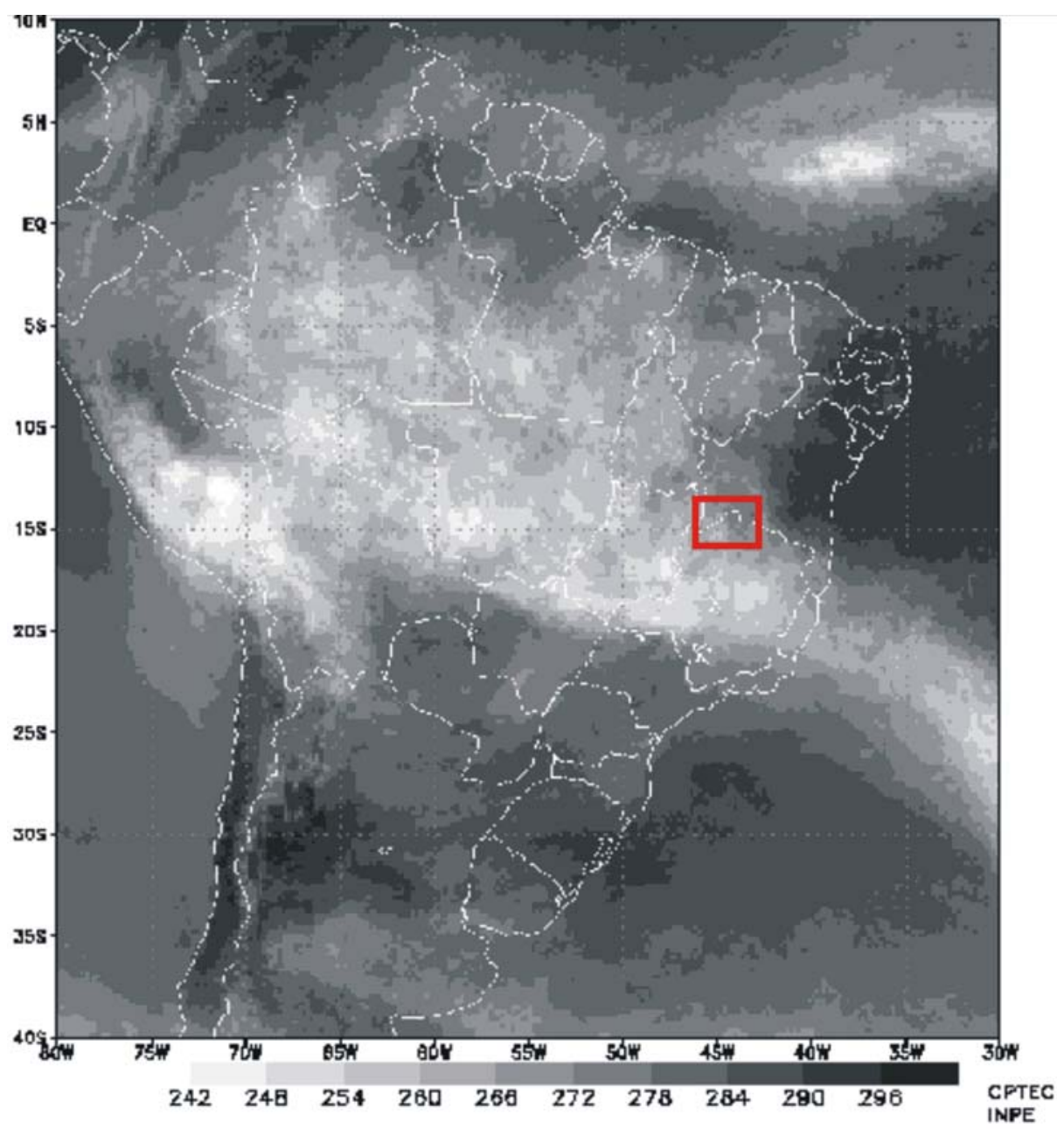

FIGURA 40: Campos de temperatura de brilho médio, obtidos através do satélite GOES 08, mostrando a presença da ZCAS no período de 02 a 06 de janeiro de 2004, com destaque na região de estudo (moldura vermelha).

Fonte: CPTEC / INPE, 2004. 
Neste período chuvas associadas ao episódio da ZCAS foram de pequena magnitude, porém excederam a média em até $100 \mathrm{~mm}$ no norte de Minas Gerais.

Este fato associa-se à rota do primeiro sistema frontal que entre os dias 1 e 3 passou sobre as localidades mineiras, principalmente Pirapora que aproximase mais da área de estudo, distando de lá aproximadamente 200 quilômetros, tendo portando influenciado de forma mais representativa as chuvas no Parque Nacional Cavernas do Peruaçu entre os dias 02 e 04, quando o volume acumulado foi de $19 \mathrm{~mm}$.

Já obtendo registros de pressão barométrica na área de estudo a partir do dia 6 de janeiro de 2004, foi observado que nos dias 6, 7 e 8 houve a manutenção de valores médios diários que oscilaram entre 924 e $925 \mathrm{hPa}$, sofrendo um ligeiro declínio nos dias 9 e 10 que registraram pressões atmosféricas médias diárias em torno dos $923 \mathrm{hPa}$.

Em decorrência da ocorrência da presença da ZCAS nestes primeiros dias de janeiro foi observada uma nebulosidade com variações diárias médias em torno dos 87 \% sobre o Parque Nacional Cavernas do Peruaçu, influenciando diretamente a quantidade de radiação solar recebida na superfície, embora a temperatura média diária registrada tenha se mantido próximo aos $28^{\circ} \mathrm{C}$, enquanto que os valores médios diários de umidade relativa de $46 \%$ entre os dias 6 e 85\% no dia 10, com variações em torno dos $63 \%$ em dias intercalados a este período (dia $7=60 \%$, dia $8=70 \%$ e dia $9=62 \%$ ).

\subsubsection{Entre os dias 11 e 20 de janeiro de 2004 .}

No período de 11 a 20, a mesma frente fria permaneceu semi-estacionária entre o litoral da Região Sudeste e o litoral da Bahia, contribuindo para a formação do segundo episódio de ZCAS entre os dias 10 e 20 de janeiro, causando muitas chuvas na porção norte de Minas Gerais (Figura 41). 


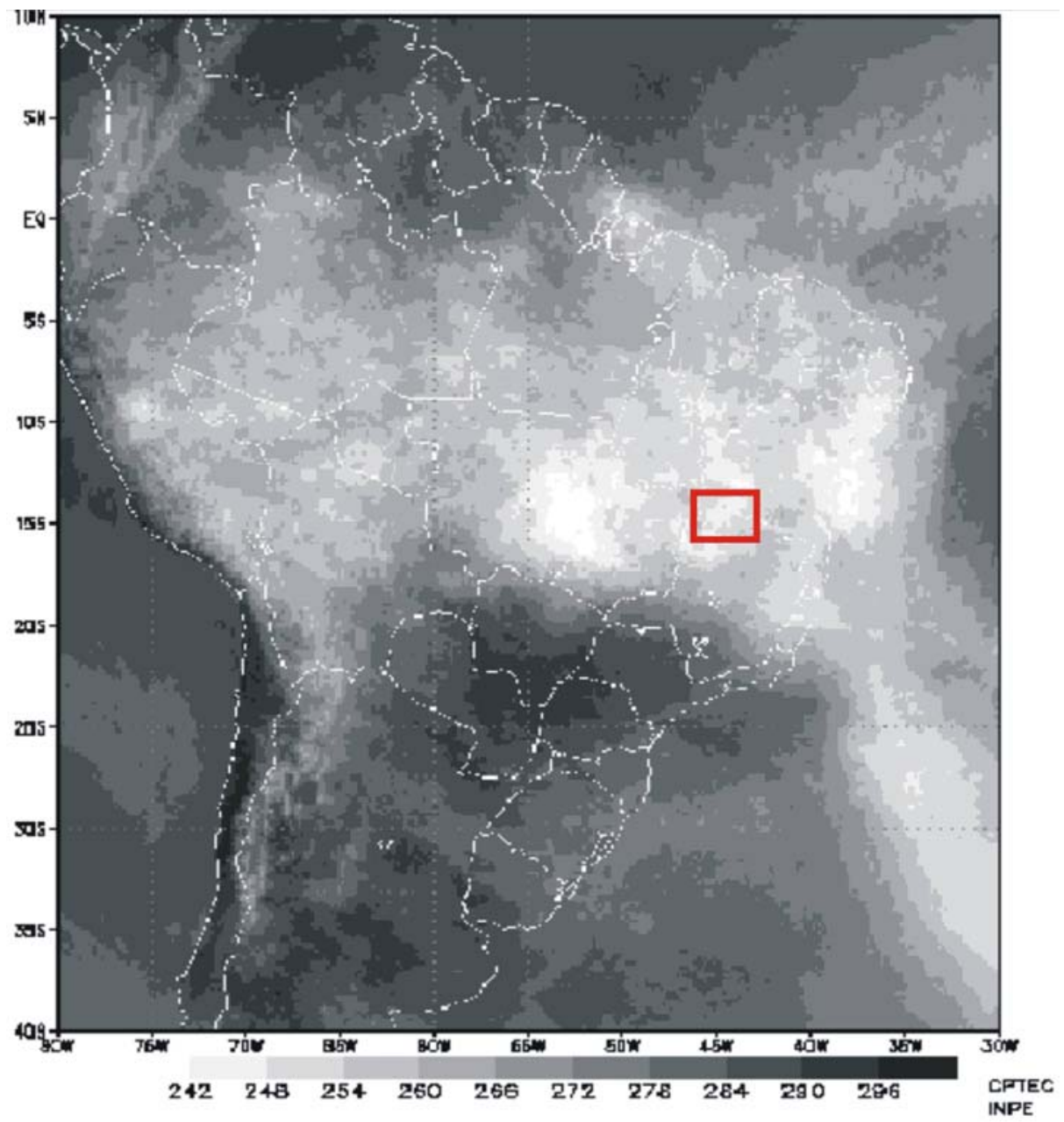

FIGURA 41: Campos de temperatura de brilho médio, obtidos através do satélite GOES 08, mostrando a presença da ZCAS no período de 10 a 20 de janeiro de 2004, com destaque na região de estudo (moldura vermelha).

Fonte: CPTEC / INPE, 2004.

Segundo o INPE (op. cit., 2004) este segundo episódio de ZCAS teve a maior duração por se manter semi-estacionada, apresentando um comportamento atípico com a banda de nebulosidade cobrindo toda a Região Nordeste e boa parte das Regiões.

Em relação à pressão atmosférica neste período, foi registrado um ligeiro aumento entre os dias 11 e 12, sofrendo um ligeiro declínio entre os dias 13 e 17 (922, aproximadamente), voltando a se elevar entre os dias 18 e 20, quando foi registrado um valor barométrico médio diário de 824 , aproximadamente.

Associada à presença da ZCAS, a taxa de nebulosidade registrada neste período manteve-se numa média próximo dos $90 \%$ de cobertura do céu. 
Com base nos dados pluviométricos coletados na área de estudo verificou-se que esse período de 11 a 20 de janeiro representou o principal evento causador das chuvas no Parque Nacional Cavernas do Peruaçu com o primeiro registro de chuva obtido já no dia 8 de janeiro e finalizando no dia 19, acumulando um volume de $233 \mathrm{~mm}$.

Também pela duração e intensidade da cobertura de nuvens e precipitação pluvial, as temperaturas registradas neste mesmo período mantiveram-se muito próximas e com pouca variação média diária, oscilando entre 24 e $25^{\circ} \mathrm{C}$, enquanto que os valores de umidade relativa, da mesma forma, mantiveram-se próximos oscilando acima dos $80 \%$, entre 85 e 90\%, aproximadamente.

\subsubsection{Entre os dias 21 e 31 de janeiro de 2004 .}

No dia 22, a segunda frente fria atingiu apenas o litoral do Rio Grande do Sul, deslocando-se para o oceano, enquanto a terceira originou-se de um cavado que se encontrava na Região Sul, no dia 26.

Este sistema interagiu com uma frente fria vinda da Argentina e teve o seu deslocamento pelo litoral do Brasil, até Porto Alegre-RS, desviando-se para o oceano, quando na área de estudo a chuva acumulada foi de $17 \mathrm{~mm}$ entre os dias 20 e 23.

Porém, no terceiro episódio da ZCAS, registrado entre 25 e 29 de janeiro (Figura 42), a banda de nebulosidade apresentou uma configuração bastante meridional, proporcionando significativo aumento das chuvas no sudeste do Brasil.

Ainda neste episódio, nota-se a presença de um vórtice ciclônico próximo ao litoral do Nordeste mantendo a ZCAS sobre o sul da Região Sudeste e alongando-se sobre a porção norte e noroeste de Minas Gerais, onde está localizada o Parque Nacional Cavernas do Peruaçu, porém sem registro de chuvas na área.

As temperaturas sofreram um ligeiro aumento acima dos $25^{\circ} \mathrm{C}$ e a umidade relativa do ar foi reduzida para valores entre 84 e 97\%, aproximadamente, indicando a situação intermediária do segundo e o terceiro episódio de ZCAS, quando a banda de nebulosidade se afastou, permitindo um ligeiro ressecamento e aquecimento do ar. 
Com formação da ZCAS a partir do dia 22, a situação registrada entre os dias 10 e 18 volta a se repetir, com redução da temperatura e aumento da umidade relativa do ar em função da banda de nebulosidade típica da ZCAS.

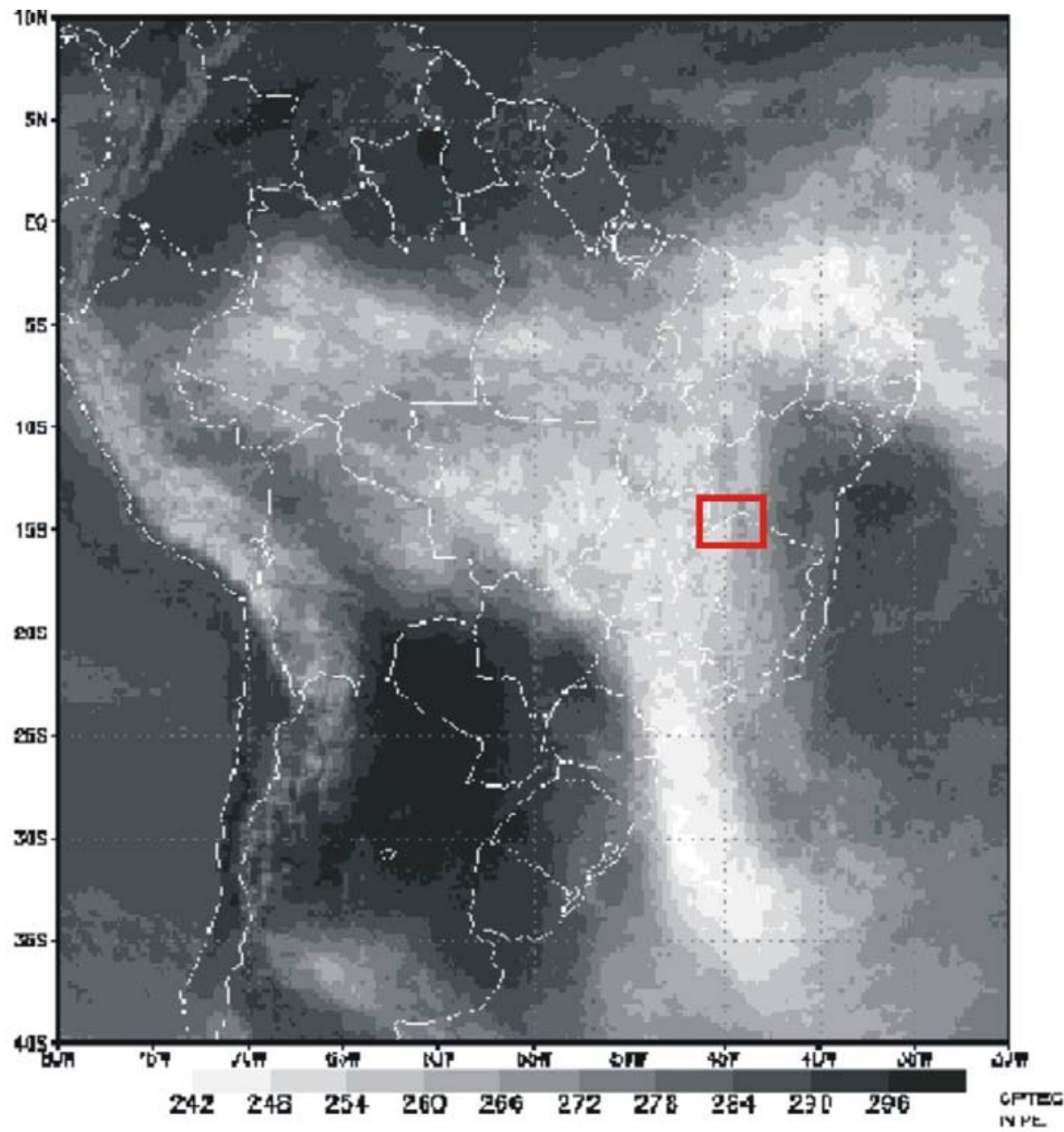

FIGURA 42: Campos de temperatura de brilho médio, obtidos através do satélite GOES 08, mostrando a presença da ZCAS no período de 25 a 29 de janeiro de 2004, com destaque na região de estudo (moldura vermelha).

Fonte: CPTEC / INPE, 2004.

Nos Gráficos 21, 22, 23, 24 e 25, apresentados abaixo são mostradas as variações diárias médias de pressão barométrica, nebulosidade, temperatura, umidade relativa do ar e pluviosidade, tendo como pano de fundo a circulação atmosférica descrita para o mês de janeiro de 2004. 
GRÁFICO 21: Variação diária média da pressão barométrica registrada no mês de janeiro de 2004 no Parque Nacional Cavernas do Peruaçu.

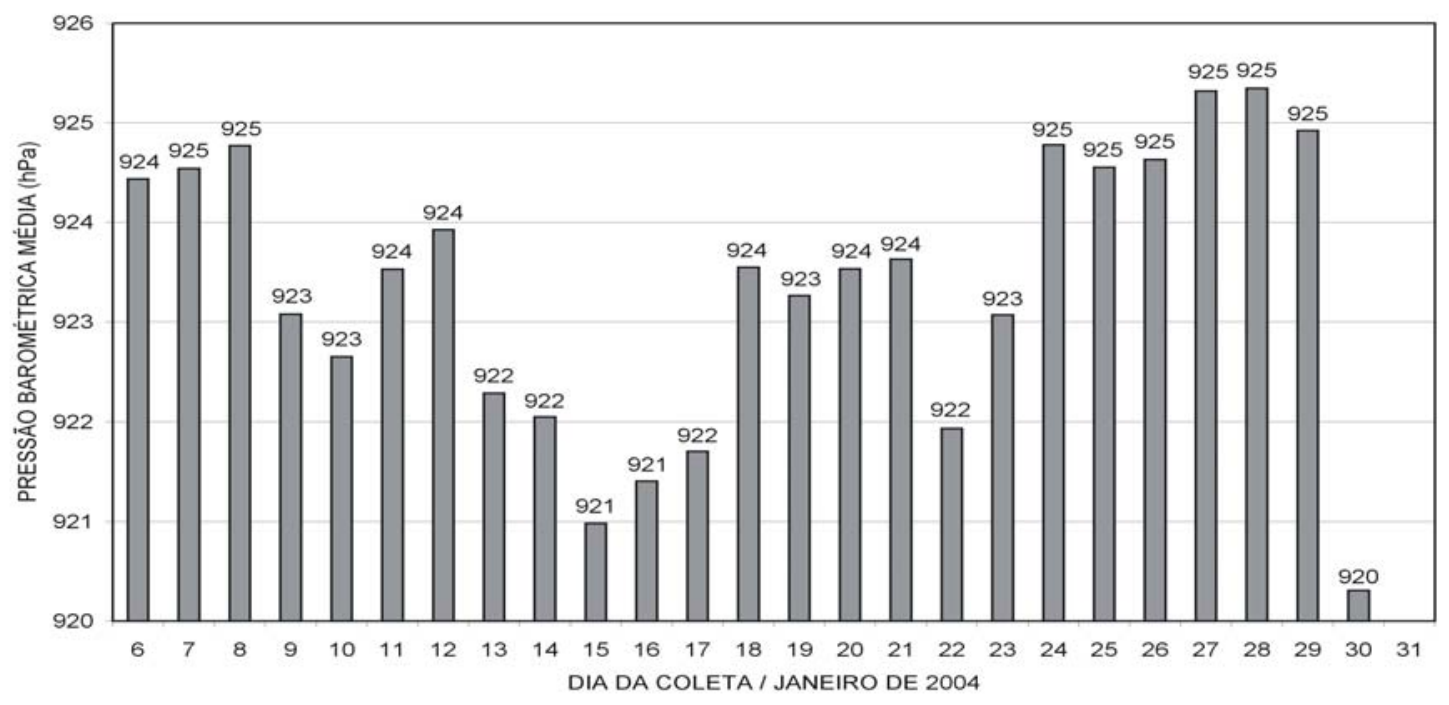

Fonte: Dados registrados em campo (janeiro de 2004).

GRÁFICO 22: Variação diária média da nebulosidade registrada no mês de janeiro de 2004 no Parque Nacional Cavernas do Peruaçu.

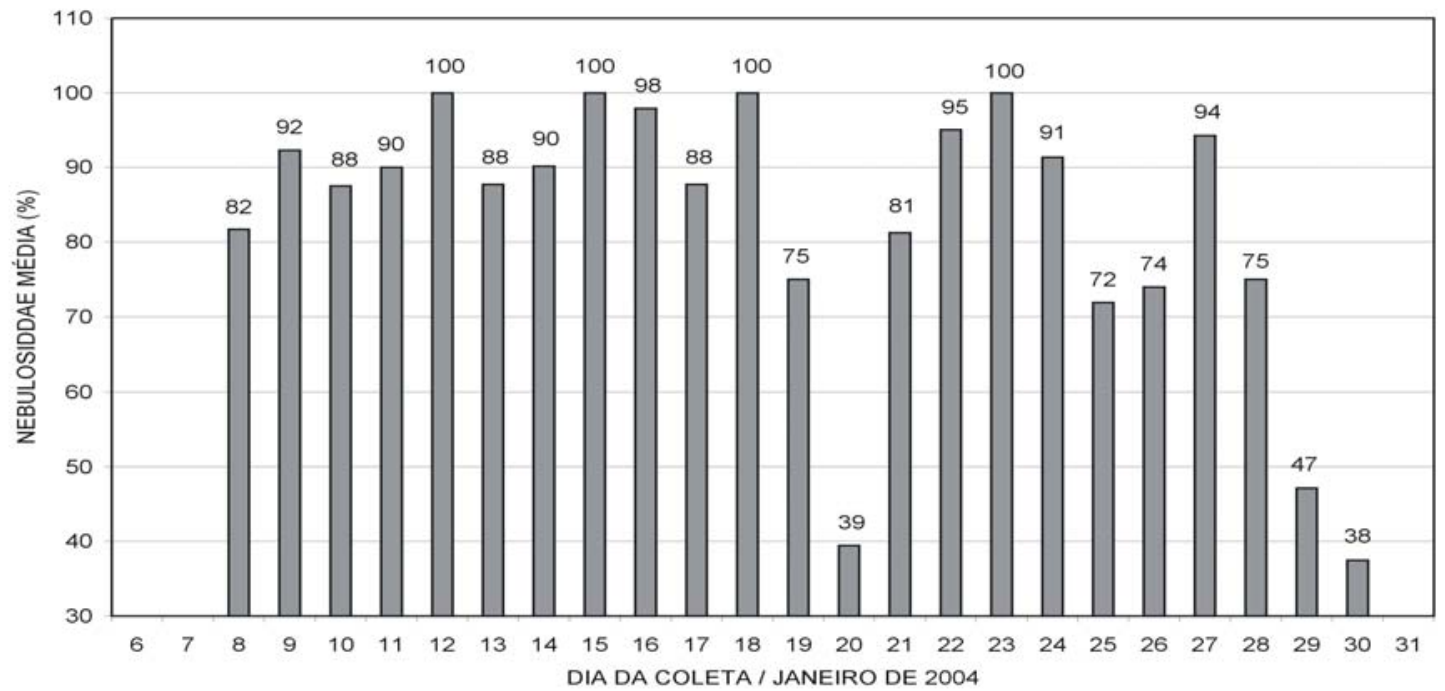

Fonte: Dados registrados em campo (janeiro de 2004). 
GRÁFICO 23: Variação diária média da temperatura do ar registrada no mês de janeiro de 2004 no Parque Nacional Cavernas do Peruaçu.

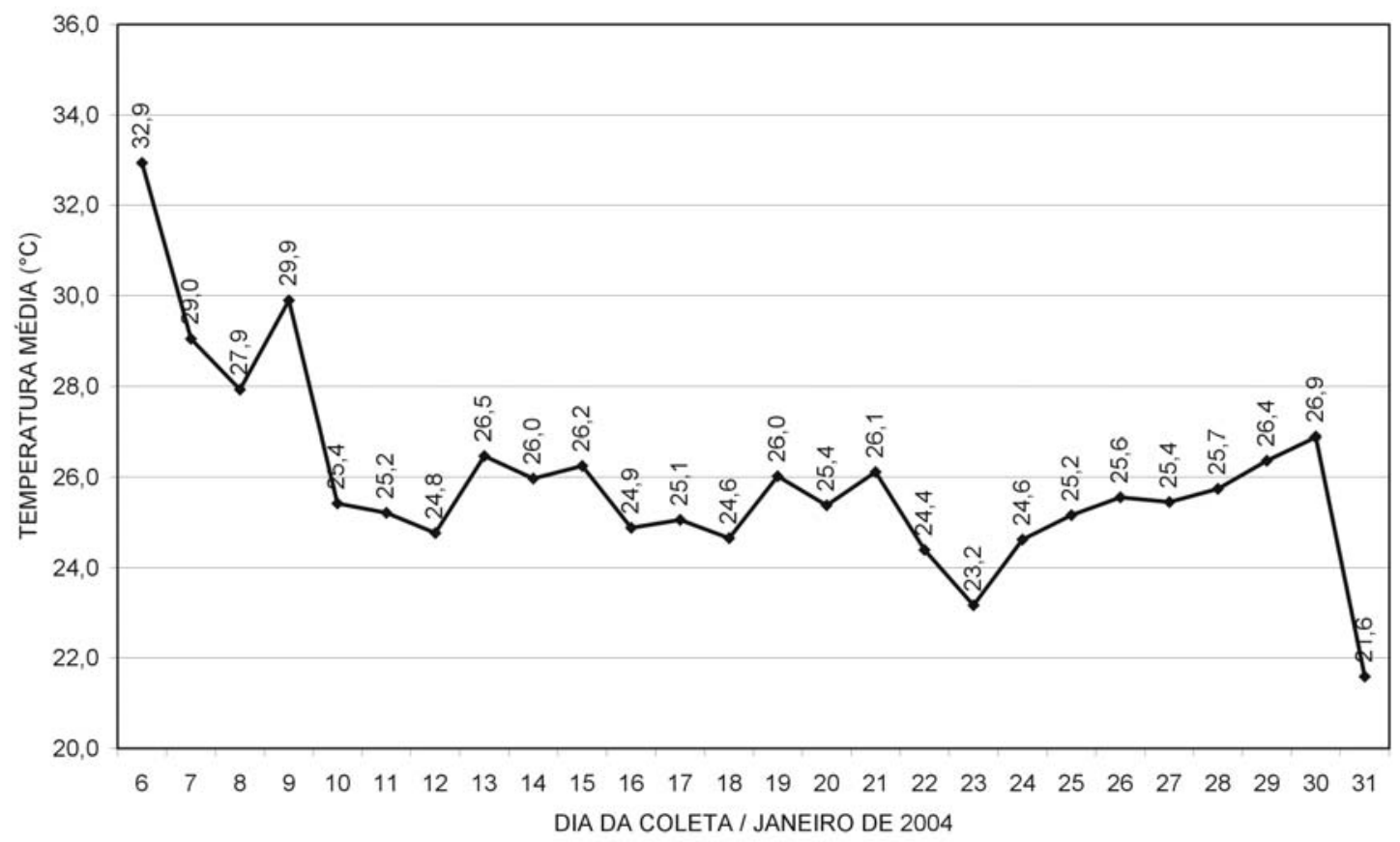

Fonte: Dados registrados em campo (janeiro de 2004).

GRÁFICO 24: Variação diária média da umidade relativa do ar registrada no mês de janeiro de 2004 no Parque Nacional Cavernas do Peruaçu.

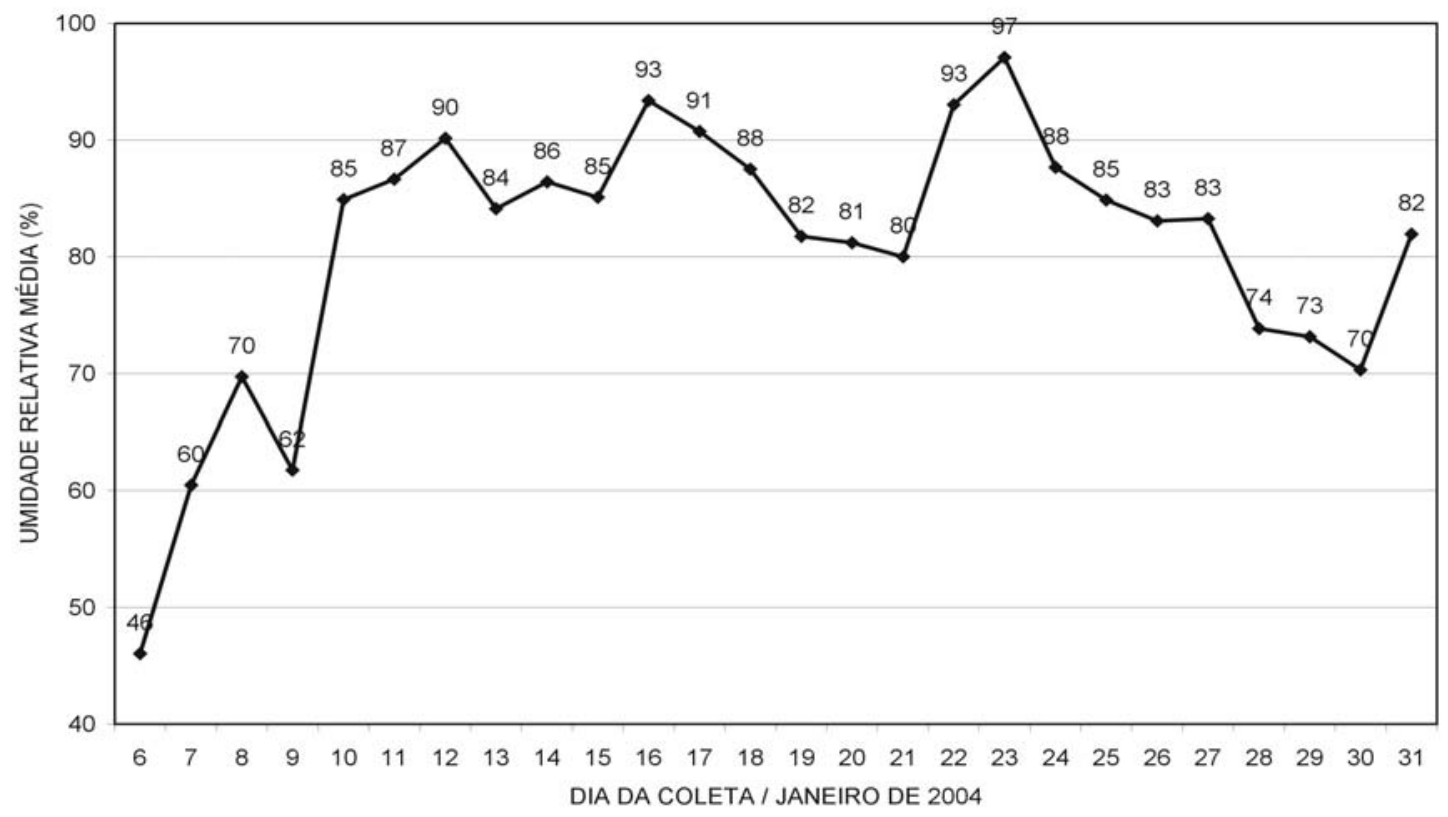

Fonte: Dados registrados em campo (janeiro de 2004). 
GRÁFICO 24: Variação diária da pluviosidade acumulada registrada no mês de janeiro de 2004 no Parque Nacional Cavernas do Peruaçu, associada aos episódios de ZCAS.

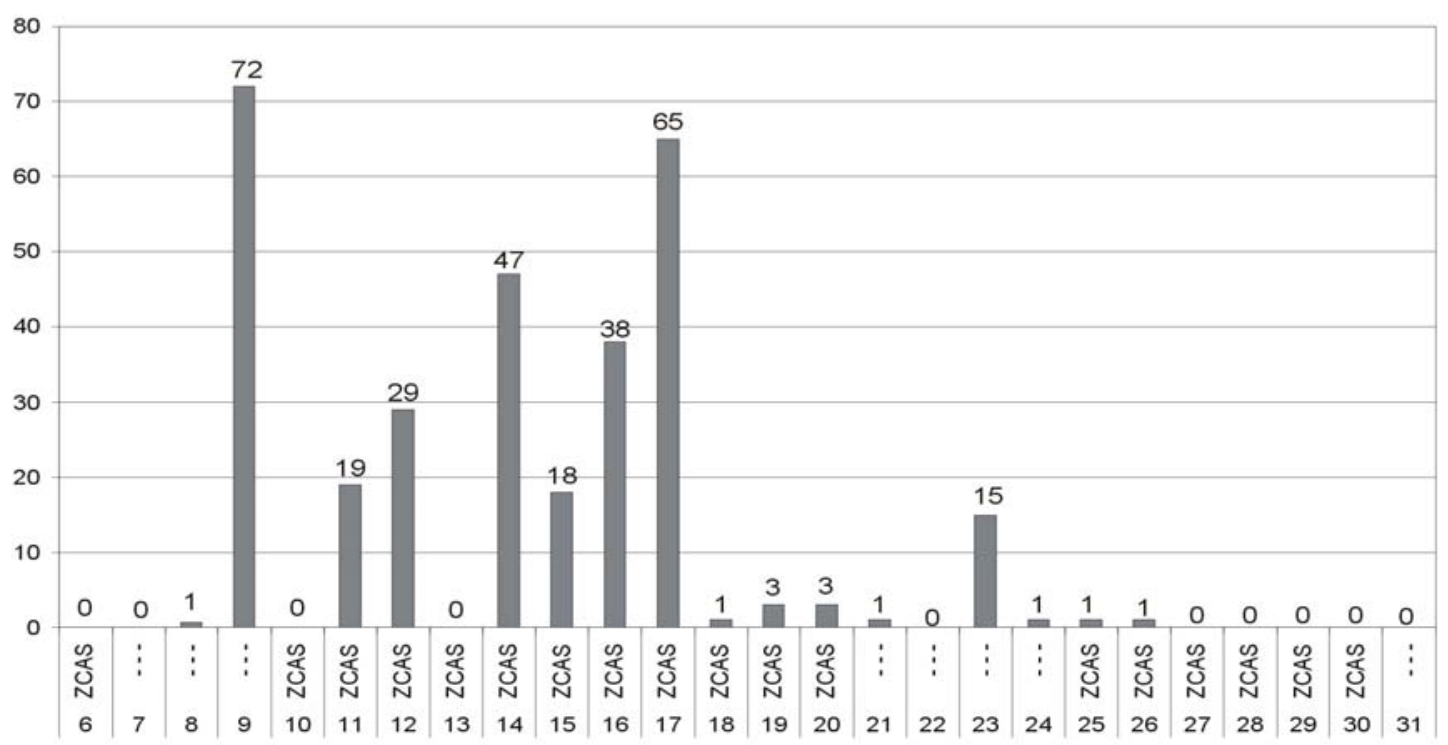

Fonte: Dados registrados em campo (janeiro de 2004).

\subsubsection{Considerações sobre a circulação atmosférica e os tipos de tempo de janeiro de 2004}

Além da influência no volume de chuva precipitada no Parque Nacional Cavernas do Peruaçu, outras variáveis também sofreram influência dessa dinâmica atmosférica.

Em decorrência dos episódios de ZCAS e do posicionamento dos vórtices ciclônicos que permaneceram estacionários sobre o Oceano Atlântico, o mês de janeiro registrou uma intensificação das atividades convectivas na Região Sudeste como um todo.

De modo geral, a intensificação de atividades convectivas ocorre com a redução da pressão barométrica que permite o avanço de sistemas atmosféricos mais carregados de vapor d'água, aumentando a nebulosidade.

No mês de janeiro a nebulosidade registrada acompanhou a passagem dos sistemas frontais e ocorrência dos episódios de ZCAS, com cobertura do céu acima dos $70 \%$ nos períodos de 8 a 18 e de 21 a 28 , coincidindo com os segundo e terceiro episódio de ZCAS.

Coincidindo com essa taxa de nebulosidade no mês de janeiro, tem-se associada a variação da temperatura e umidade relativa do ar que, entre os 
dias 10 e 18 registrou temperaturas médias diárias variando entre 24 e $25^{\circ}$ e umidade relativa do ar em torno dos $92 \%$.

\subsubsection{A TEMPERATURA DO AR}

Com base nos dados de campo coletados em janeiro de 2004 no Parque Nacional Cavernas do Peruaçu e seu entorno, a temperatura média obtida foi de $25,9^{\circ} \mathrm{C}$ para todo o período, com a mínima e a máxima absolutas de $14,8^{\circ} \mathrm{C}$ (Ponto $\mathrm{n}^{\circ}$. 14, às $06 \mathrm{~h} 00 \mathrm{minh}$ ) e $37,7^{\circ} \mathrm{C}$ (Ponto $\mathrm{n}^{\circ}$. 08, às $17 \mathrm{~h} 00 \mathrm{minh}$ ), respectivamente.

Assim como ocorreu em julho de 2003, comparada com a normal climatológica das estações meteorológicas do INMET de Espinosa, Formosa, Monte Azul, Montes Claros e Posse (Tabela 06), a temperatura média de janeiro de 2004 do Parque Nacional Cavernas do Peruaçu apresentou-se mais elevada em relação à condição térmica média registrada entre 1961 e $1990\left(23,8^{\circ} \mathrm{C}\right)$.

TABELA 06: Temperatura média $\left({ }^{\circ} \mathrm{C}\right)$ entre 1961 e 1990 no mês de janeiro nas estações meteorológicas do INMET circundantes ao Parque Nacional Cavernas do Peruaçu e temperatura média $\left({ }^{\circ} \mathrm{C}\right)$ desta Unidade de Conservação em janeiro de 2004.

\begin{tabular}{|c|c|c|}
\hline $\begin{array}{l}\text { PERÍODO } \\
\text { CONSIDERADO }\end{array}$ & NOME & TEMPERATURA MÉDIA $\left({ }^{\circ} \mathrm{C}\right.$ \\
\hline \multirow{6}{*}{$1961-1990$} & ESPINOSA & 24,9 \\
\hline & FORMOSA & 22,2 \\
\hline & MONTE AZUL & 24,4 \\
\hline & MONTES CLAROS & 23,5 \\
\hline & POSSE & 24,0 \\
\hline & MÉDIA (1961 - 1990) & 23,8 \\
\hline $\begin{array}{l}\text { JANEIRO DE } \\
2004\end{array}$ & $\begin{array}{l}\text { PARQUE NACIONAL CAVERNAS } \\
\text { DO PERUAÇU }\end{array}$ & 25,9 \\
\hline
\end{tabular}

Fonte: Dados registrados em campo (janeiro de 2004).

Neste período (janeiro de 2004), as temperaturas registradas nos pontos de amostragem mais recorrentes concentraram-se entre 22 e $26^{\circ} \mathrm{C}$, representando juntas $55 \%$ de toda a amostra. 
Outra classe representativa de temperaturas registradas nos pontos de amostragem compreende as temperaturas de 20 e $28^{\circ} \mathrm{C}$ que apresentaram uma freqüência relativa de $15 \mathrm{e} 12 \%$, respectivamente de todos os valores obtidos na escala horária (Gráfico 26).

Considerando a temperatura média de cada ponto de amostragem verifica-se que as temperaturas médias mais recorrentes oscilaram entre 25 e $26^{\circ} \mathrm{C}$ representando $52 \%$ de toda a amostragem média de temperatura dos pontos, como podem ser observados no Gráfico 27.

GRÁFICO 26: Distribuição de freqüência $(\%)$ da temperatura $\left({ }^{\circ} \mathrm{C}\right)$ registrada no Parque Nacional Cavernas do Peruaçu (janeiro de 2004).

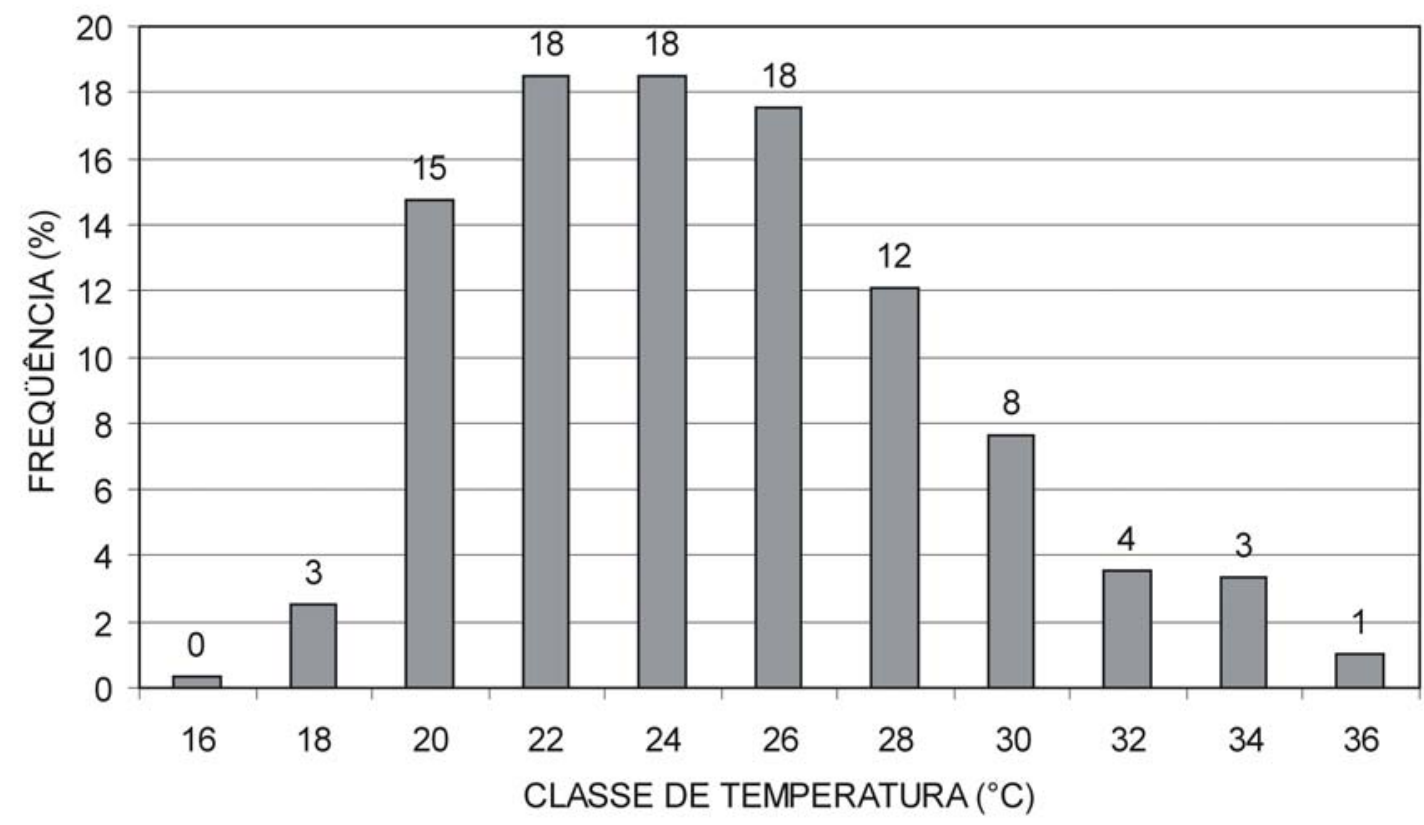

Fonte: Dados registrados em campo (janeiro de 2004). 
GRÁFICO 27: Distribuição de freqüência (\%) da temperatura média $\left({ }^{\circ} \mathrm{C}\right)$ dos pontos de amostragem no Parque Nacional Cavernas do Peruaçu (janeiro de 2004).

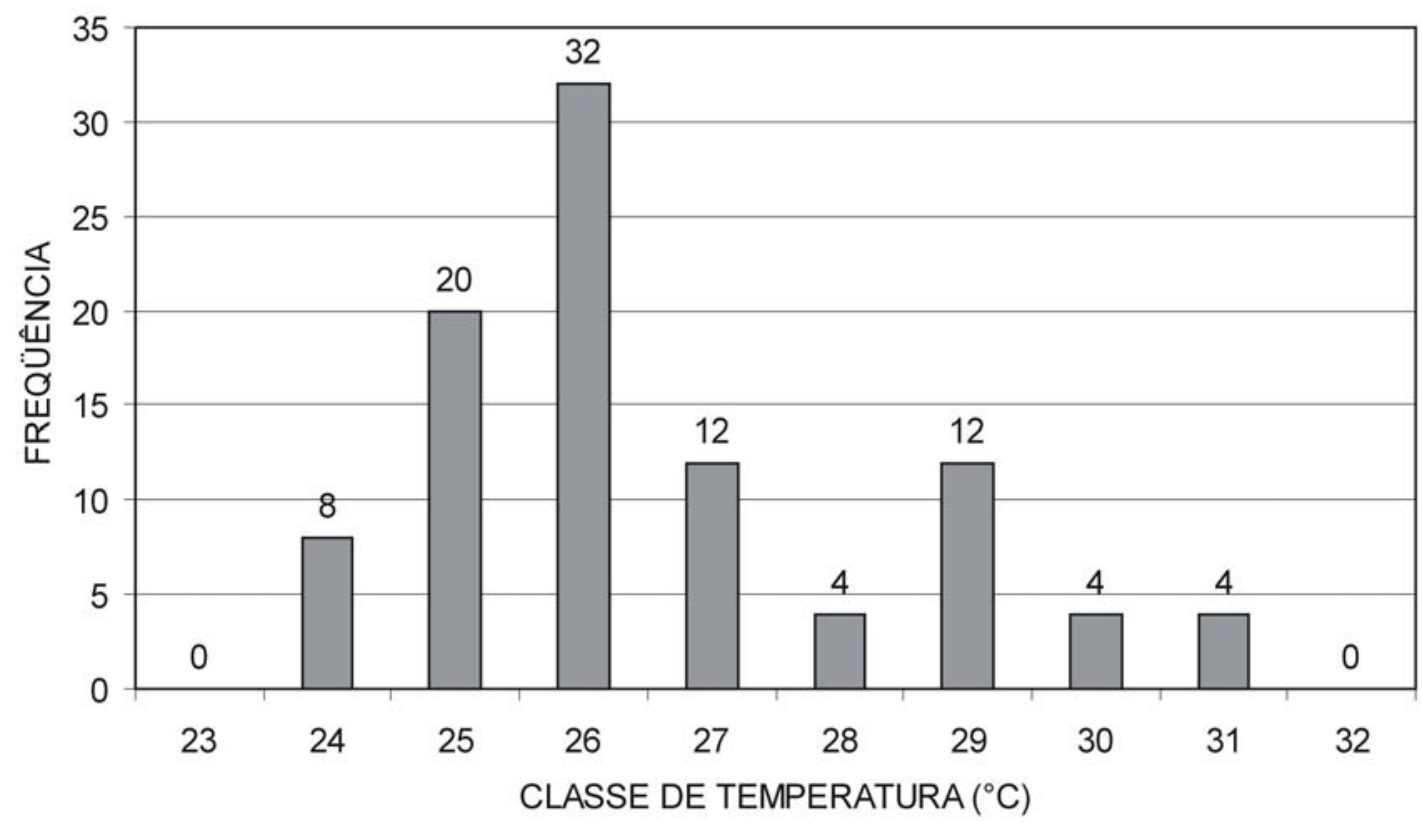

Fonte: Dados registrados em campo (janeiro de 2004).

Com base na cotas altimétricas na área de estudo que variam entre 440 e 830 , aproximadamente, constatou-se que os pontos de amostragem localizados em cotas altimétricas mais baixas (entre 440 e 500 metros) apresentaram temperaturas mais elevadas $\left(27,6^{\circ} \mathrm{C}\right)$.

Nas cotas entre 500 e 760 metros as temperaturas variaram em torno dos 25 ${ }^{\circ} \mathrm{C}$, portanto, representando um ambiente aquecido e, naqueles pontos acima dos 760 metros a temperatura média foi de $23,5^{\circ} \mathrm{C}$, demonstrando assim que nas cotas mais baixas o ambiente é mais quente do que aqueles que estão localizados mais acima, no contexto da área mapeada (Gráfico 28). 
GRÁFICO 28: Temperatura média $\left({ }^{\circ} \mathrm{C}\right)$ dos pontos de amostragem distribuída segundo as cotas altimétricas do Parque Nacional Cavernas do Peruaçu (janeiro de 2004).

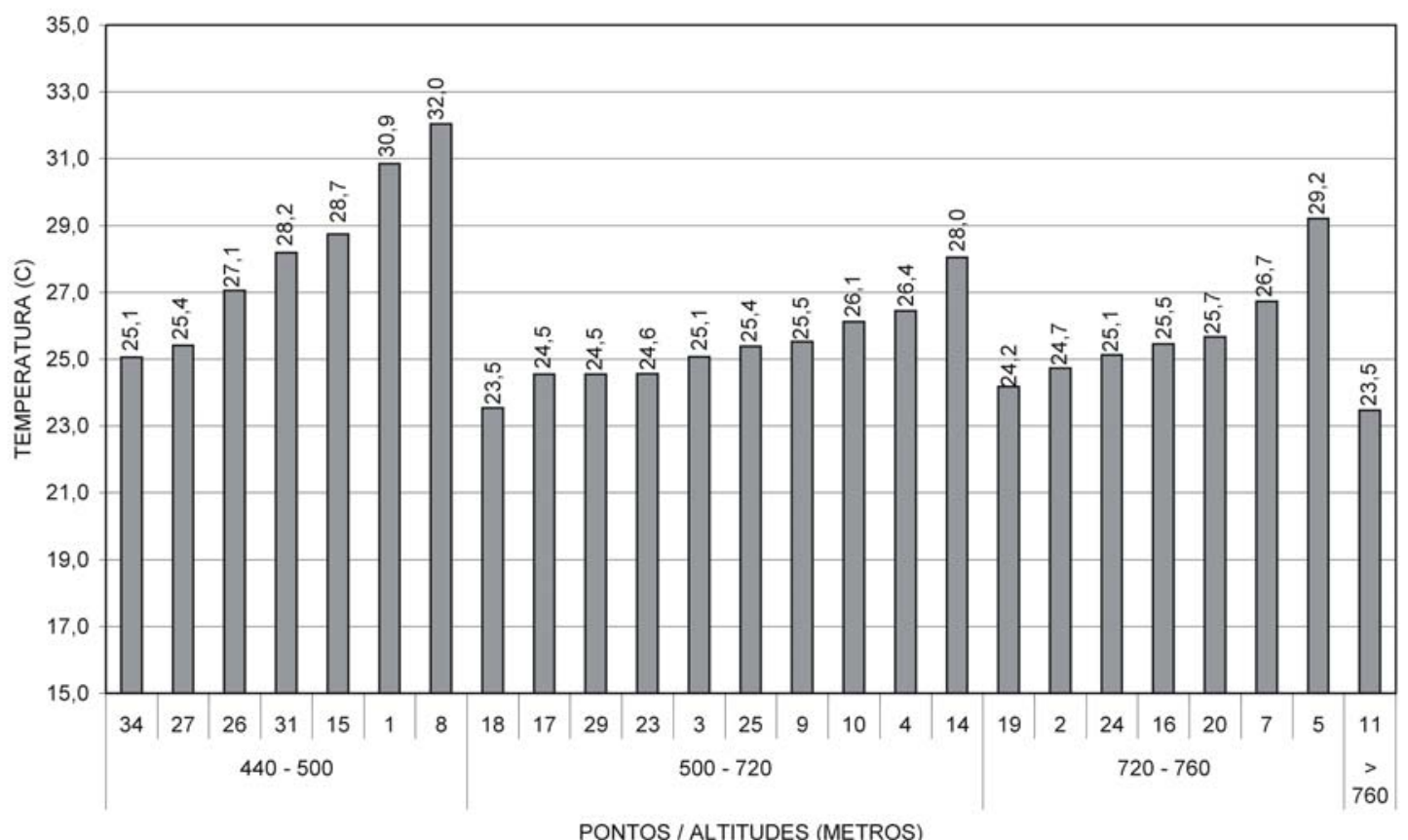

Fonte: Dados registrados em campo (janeiro de 2004).

Dessa forma, considerando a variação de temperatura de janeiro de 2004 em relação às cotas altimétricas em que se distribuem os pontos de amostragem e os respectivos compartimentos geomorfológicos presentes na área de estudo, são observados os seguintes aspectos:

O Compartimento da Depressão do Rio São Francisco que apresenta uma altitude entre 440 e 500 metros configura-se como o mais aquecido $\left(27,6^{\circ} \mathrm{C}\right)$;

No Compartimento do Planalto dos Gerais localizados em cotas altimétricas acima dos 760 metros, foi registrada a temperatura média mais baixas $\left(23,5^{\circ} \mathrm{C}\right) ; \mathrm{e}$,

Intermediário a estes dois compartimentos mais extremos, tem-se o Compartimento Carstificado (500 e 720 metros) e aquele da Zona de Transição (720 e 760 metros) onde as temperaturas médias foram de 25,4 e $25,3^{\circ} \mathrm{C}$, respectivamente.

Na Tabela 07 a seguir, é apresentada a relação de pontos de amostragem em relação aos compartimentos geomorfológicos e suas respectivas temperaturas médias $\left({ }^{\circ} \mathrm{C}\right)$. 
TABELA 07: Relação dos compartimentos geomorfológicos do Parque Nacional Cavernas do Peruaçu e a temperatura média $\left({ }^{\circ} \mathrm{C}\right)$ registrada nos pontos de amostragem ali localizados (janeiro de 2004).

\begin{tabular}{|c|c|c|}
\hline COMPARTIMENTO GEOMORFOLÓGICO & $\begin{array}{l}\text { PONTO DE } \\
\text { AMOSTRAGEM }\end{array}$ & $\begin{array}{l}\text { TEMPERATURA } \\
\left.\text { MÉDIA ( }{ }^{\circ} \mathrm{C}\right)\end{array}$ \\
\hline \multirow{14}{*}{ COMPARTIMENTO CARSTIFICADO } & 18 & 23,5 \\
\hline & 17 & 24,5 \\
\hline & 29 & 24,5 \\
\hline & 23 & 24,6 \\
\hline & 03 & 25,1 \\
\hline & 25 & 25,4 \\
\hline & 9 & 25,5 \\
\hline & 10 & 26,1 \\
\hline & 4 & 26,4 \\
\hline & 14 & 28,0 \\
\hline & 18 & 23,5 \\
\hline & 17 & 24,5 \\
\hline & 29 & 24,5 \\
\hline & 23 & 24,6 \\
\hline \multicolumn{2}{|l|}{ MÉDIA } & 25,4 \\
\hline \multirow{7}{*}{$\begin{array}{l}\text { COMPARTIMENTO DA DEPRESSÃO DO RIO SÃO } \\
\text { FRANCISCO }\end{array}$} & 34 & 25,1 \\
\hline & 27 & 25,4 \\
\hline & 26 & 27,1 \\
\hline & 31 & 28,2 \\
\hline & 15 & 28,7 \\
\hline & 01 & 30,9 \\
\hline & 08 & 32,0 \\
\hline \multicolumn{2}{|l|}{ MÉDIA } & 27,6 \\
\hline \multirow{7}{*}{ COMPARTIMENTO DA ZONA DE TRANSIÇÃO } & 19 & 24,2 \\
\hline & 02 & 24,7 \\
\hline & 24 & 25,1 \\
\hline & 16 & 25,5 \\
\hline & 20 & 25,7 \\
\hline & 07 & 26,7 \\
\hline & 05 & 29,2 \\
\hline \multicolumn{2}{|l|}{ MÉDIA } & 23,2 \\
\hline COMPARTIMENTO DO PLANALTO DOS GERAIS & 11 & 23,5 \\
\hline \multicolumn{2}{|l|}{ MÉDIA } & 23,5 \\
\hline \multicolumn{2}{|l|}{ MÉDIA TOTAL } & 25,9 \\
\hline
\end{tabular}

Fonte: Dados registrados em campo (janeiro de 2004).

Assim como ocorreu no mês de julho de 2003, as temperaturas elevadas do Compartimento da Depressão do Rio São Francisco estão aos padrões de uso e formas de ocupação do solo ali predominantes, devendo os aspectos altimétricos e geomorfológicos serem entendidos como controles climáticos secundários.

Visando um melhor entendimento da temperatura média registrada em cada compartimento geomorfológico, considerou-se a freqüência de ocorrência dos valores de temperatura em relação a esses compartimentos quando foram observadas e destacadas as seguintes características: 
O Compartimento Carstificado foi o ambiente que mais apresentou variação térmica ao longo do período considerado (janeiro de 2004), onde predominaram as temperaturas entre 25 e $26^{\circ} \mathrm{C}$, representando quase $25 \%$ de toda amostra;

No Compartimento da Depressão do Rio São Francisco, as temperaturas próximas dos $29^{\circ} \mathrm{C}$ foram as mais representativas. Exceto as temperaturas desta classe, a freqüência dos demais valores manteve-se semelhante àquela dos outros compartimentos (4\%);

No Compartimento da Zona de Transição a maior freqüência de temperaturas médias dos pontos de amostragem esteve em torno dos $26^{\circ} \mathrm{C}$; e,

No Compartimento do Planalto dos Gerais, a temperatura predominante está em torno dos $24^{\circ} \mathrm{C}$ (Gráfico 29 ).

GRÁFICO 29: Distribuição de freqüência (\%) da temperatura média $\left({ }^{\circ} \mathrm{C}\right)$ dos pontos de amostragem segundo os compartimentos geomorfológicos do Parque Nacional Cavernas do Peruaçu (janeiro de 2004).

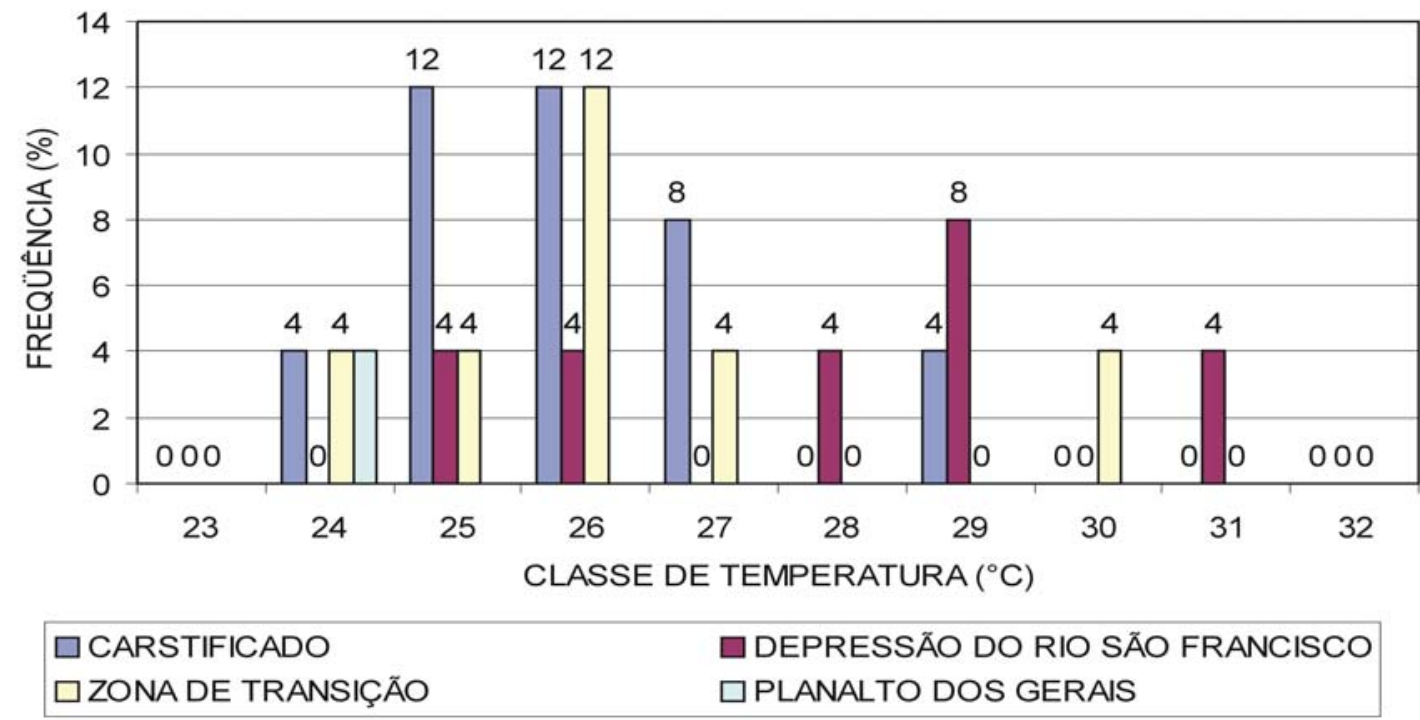

Fonte: Dados registrados em campo (janeiro de 2004).

Para a distribuição das temperaturas médias dos pontos de amostragem em relação às unidades de paisagens das geofácies observa-se que a variação térmica destes ambientes apresentou as mesmas características daquelas observadas em julho de 2003, quando identificou as Geofácies do Ambiente Antropogênico e da Savânica Estépica como os mais aquecidos, como segue: 
Na Geofácie dos Ambientes Antropogênicos a temperatura média registrada foi de $26,6^{\circ} \mathrm{C}$, representando a mais elevada dentre todas as outras geofácies;

A Geofácie da Formação Savânica Estépica foi a segunda unidade de paisagem mais quente, registrando uma temperatura média de $25,4^{\circ} \mathrm{C}$; e

As Geofácies da Formação Savânica e Formação Florestal apresentaram temperaturas médias próximas dos $25^{\circ} \mathrm{C}$ (Gráfico 30 ).

GRÁFICO 30: Temperatura média $\left({ }^{\circ} \mathrm{C}\right)$ registrada nas unidades de paisagem das geofácies do Parque Nacional Cavernas do Peruaçu (janeiro de 2004).

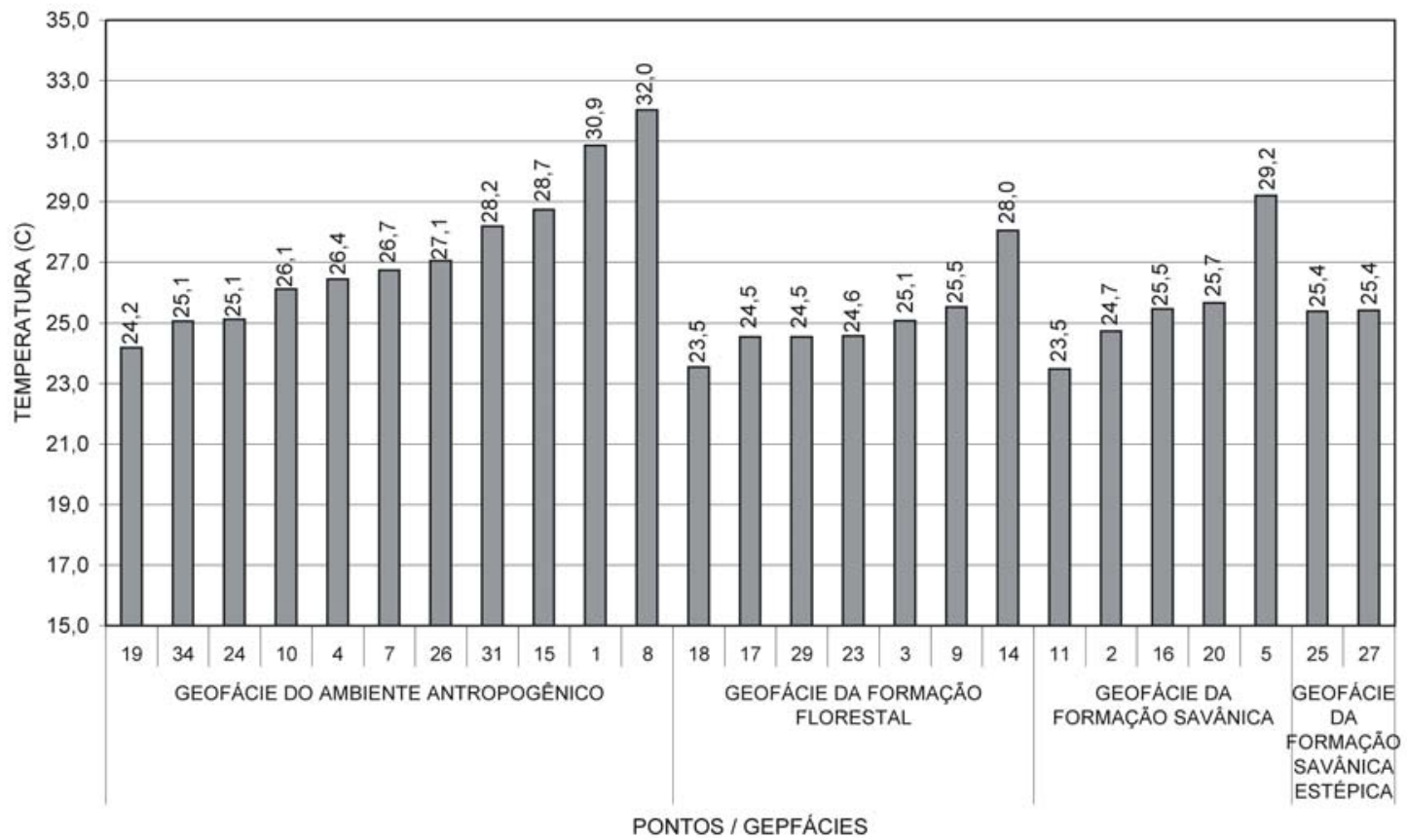

Fonte: Dados registrados em campo (janeiro de 2004).

Considerando as informações da temperatura obtidas nos pontos de amostragem segundo as unidades de paisagem enquadradas na escala das geofácies, a seguir a temperatura será analisada tendo como referência fisiográfica as unidades de paisagens dos Geossistemas.

Assim como foi observado no período de julho de 2003, o Geossistema da Depressão do Rio São Francisco em janeiro de 2004 manteve-se na condição do ambiente mais aquecido da área de estudo, registrando uma temperatura média dos pontos de amostragem ali localizados de $27,6^{\circ} \mathrm{C}$ (médias mínima e máxima de 25,1 e $32^{\circ} \mathrm{C}$, respectivamente)

Nos dois outros geossistemas, essa semelhança com julho também foi mantida. No Geossistema da Serras da Mãe Joana e do Cardoso de Minas a temperatura média foi de $24,9^{\circ} \mathrm{C}$ (médias mínima e máxima de 23,5 e $25,7^{\circ} \mathrm{C}$, 
respectivamente), enquanto que no Geossistema do Planalto do Rio São Francisco, a temperatura média foi de $25,4^{\circ} \mathrm{C}$ (médias mínima e máxima de 23,5 e $29,2^{\circ} \mathrm{C}$, respectivamente) (Gráfico 31 ).

GRÁFICO 31: Temperatura média $\left({ }^{\circ} \mathrm{C}\right)$ dos geossistemas do Parque Nacional Cavernas do peruaçu (janeiro de 2004).

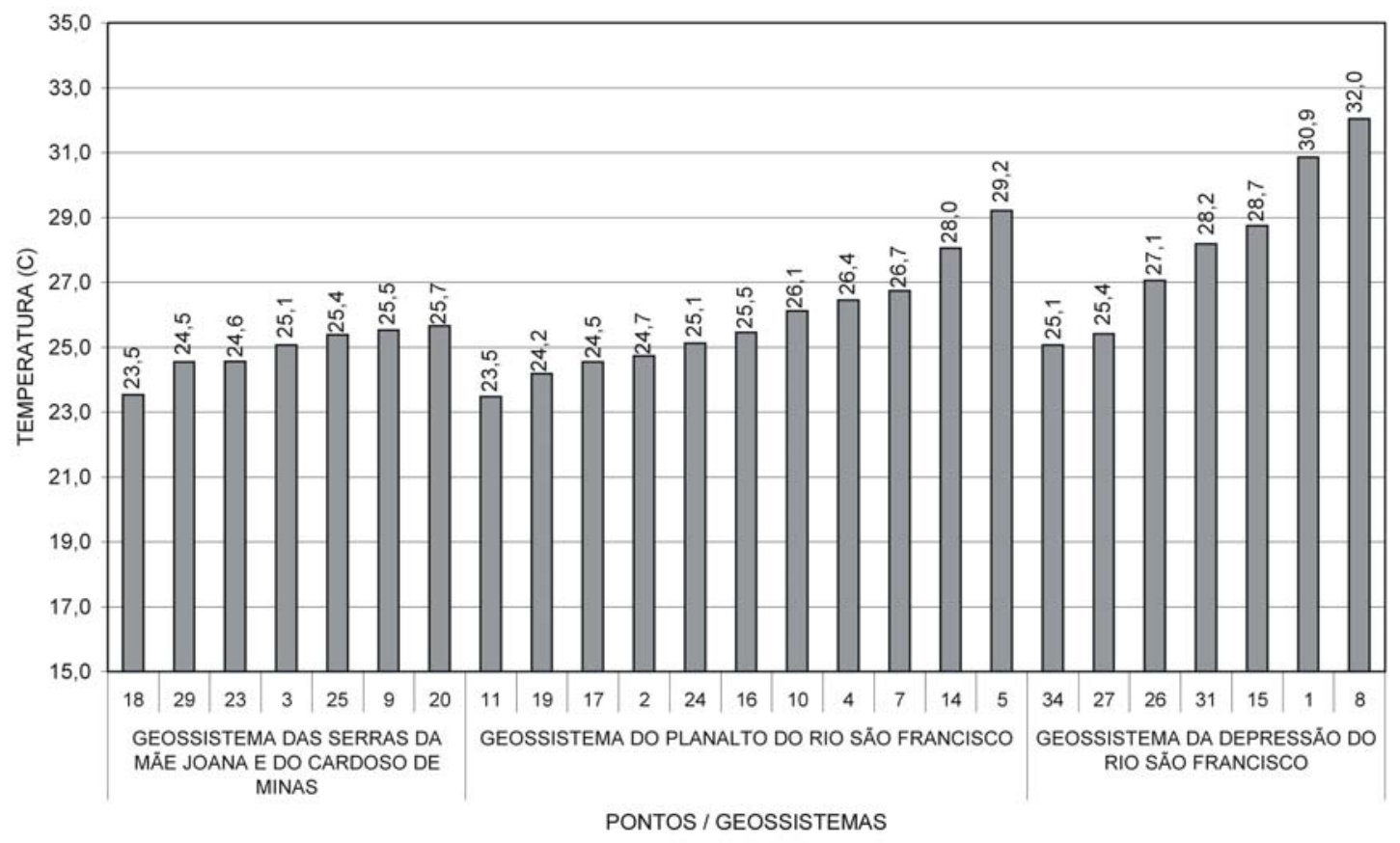

Fonte: Dados registrados em campo (janeiro de 2004).

Considerando as informações sobre as temperaturas obtidas nos pontos de amostragem e unidades de paisagem enquadradas na escala das geofácies e dos geossistemas, na Figura 43 é apresentada a distribuição dos valores médios de temperatura sobre a área mapeada no mês de janeiro de 2004, com destaque para o Parque Nacional Cavernas do Peruaçu.

Em decorrência do próprio período do ano, a variação térmica registrada na área de estudo apresentou uma amplitude maior do que aquela verificada em julho de 2003 , oscilando entre 23 e $31^{\circ} \mathrm{C}$, aproximadamente.

No contexto da área mapeada, as temperaturas médias mais elevadas se concentraram, predominantemente sobre a porção norte e nordeste da área de estudo com temperaturas oscilando em torno dos $30^{\circ} \mathrm{C}$.

Outra porção que apresentou as temperaturas mais elevadas localiza-se na porção pertencente ao Parque Nacional Cavernas do Peruaçu localizada no compartimento geomorfológico da Depressão do Rio São Francisco, enquanto que sobre a porção central e sul da área de estudo, as temperaturas médias ficaram entre 23 e $26^{\circ} \mathrm{C}$. 


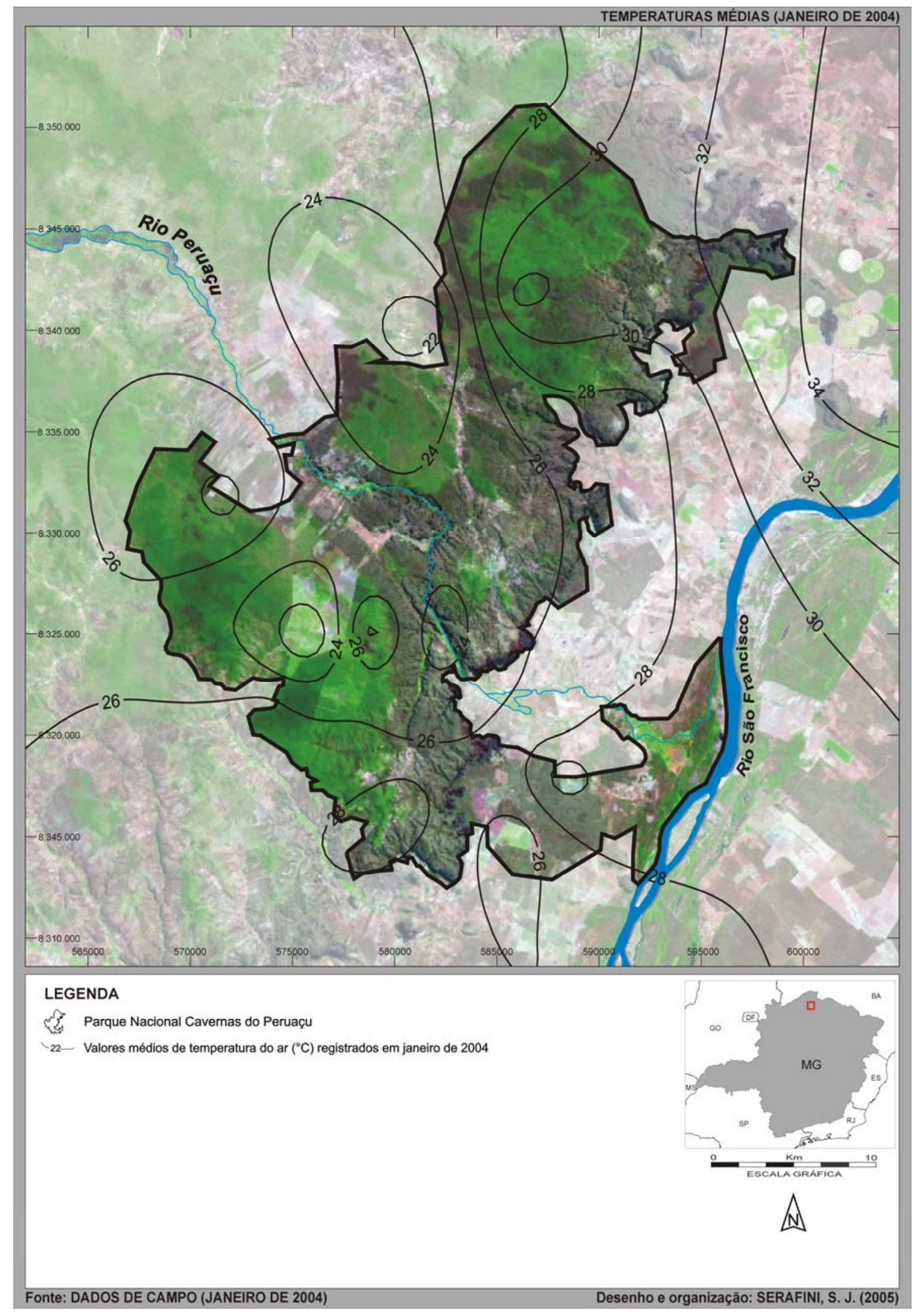

FIGURA 43: Temperatura média $\left({ }^{\circ} \mathrm{C}\right)$ do Parque Nacional Cavernas do Peruaçu no mês de janeiro de 2004. 


\subsubsection{A UMIDADE RELATIVA DO AR}

Com base nos dados coletados em janeiro de 2004, foi registrada para toda a área de estudo uma umidade relativa do ar média de $82 \%$, como a mínima e a máxima absolutas de $32 \%$ (Ponto $\mathrm{n}^{\circ}$. 01 às $17 \mathrm{~h} 00 \mathrm{~min}$ ) e $99 \%$ (vários ponto $\mathrm{n}^{\circ}$. entre $06 \mathrm{~h} 00 \mathrm{~min}$ e $08 \mathrm{~h} 00 \mathrm{~min}$ e $17 \mathrm{~h} 00 \mathrm{~min}$ e $18 \mathrm{~h} 00 \mathrm{~min})$, respectivamente.

Comparando a umidade relativa do ar média (82\%) deste período com a normal climatológica das estações meteorológicas do INMET de Espinosa, Formosa, Monte Azul, Montes Claros e Posse, o Parque Nacional Cavernas do Peruaçu configurou-se como um ambiente mais úmido do que a média climatológica das estações vizinhas (74\%), como mostra a Tabela 08.

TABELA 08: Umidade relativa do ar média (\%) entre 1961 e 1990 no mês de janeiro nas estações meteorológicas do INMET circundantes ao Parque Nacional Cavernas do Peruaçu e umidade relativa do ar média (\%) desta Unidade de Conservação em janeiro de 2004.

\begin{tabular}{l|l|c}
\hline \multicolumn{1}{c|}{$\begin{array}{c}\text { PERÍODO } \\
\text { CONSIDERADO }\end{array}$} & \multicolumn{1}{|c}{ NOME } & $\begin{array}{c}\text { UMIDADE RELATIVA MÉDIA } \\
(\%)\end{array}$ \\
\hline & ESPINOSA & 68 \\
\cline { 2 - 3 } & FORMOSA & 80 \\
\cline { 2 - 3 } $1961-1990$ & MONTE AZUL & 72 \\
\cline { 2 - 3 } & MONTES CLAROS & 74 \\
\cline { 2 - 3 } & POSSE & 79 \\
\cline { 2 - 3 } & MÉDIA (1961 - 1990) & 74 \\
\hline \multirow{2}{*}{\begin{tabular}{l} 
JANEIRO DE \\
\cline { 2 - 3 }
\end{tabular}} & $\begin{array}{l}\text { PARQUE NACIONAL CAVERNAS } \\
\text { DO PERUAÇU }\end{array}$ & 82 \\
\hline
\end{tabular}

Fonte: Dados registrados em campo (janeiro de 2004).

Identificando a freqüência de umidade relativa do ar média dos pontos de amostragem verifica-se que, os principais valores médios registrados estiveram próximos dos $100 \%$, representando $32 \%$ da amostra, seguido pelos valores de 80 a $90 \%$ que juntos totalizam $52 \%$ da amostra, enquanto que a umidade relativa do ar abaixo dos $70 \%$ (de 60 a $70 \%$ ) não foi representativa para o período, não ultrapassando $20 \%$ dos registros (Gráfico 32 ). 
GRÁFICO 32: Distribuição de freqüência (\%) da umidade relativa média (\%) dos pontos de amostragem no Parque Nacional Cavernas do Peruaçu (janeiro de 2004).

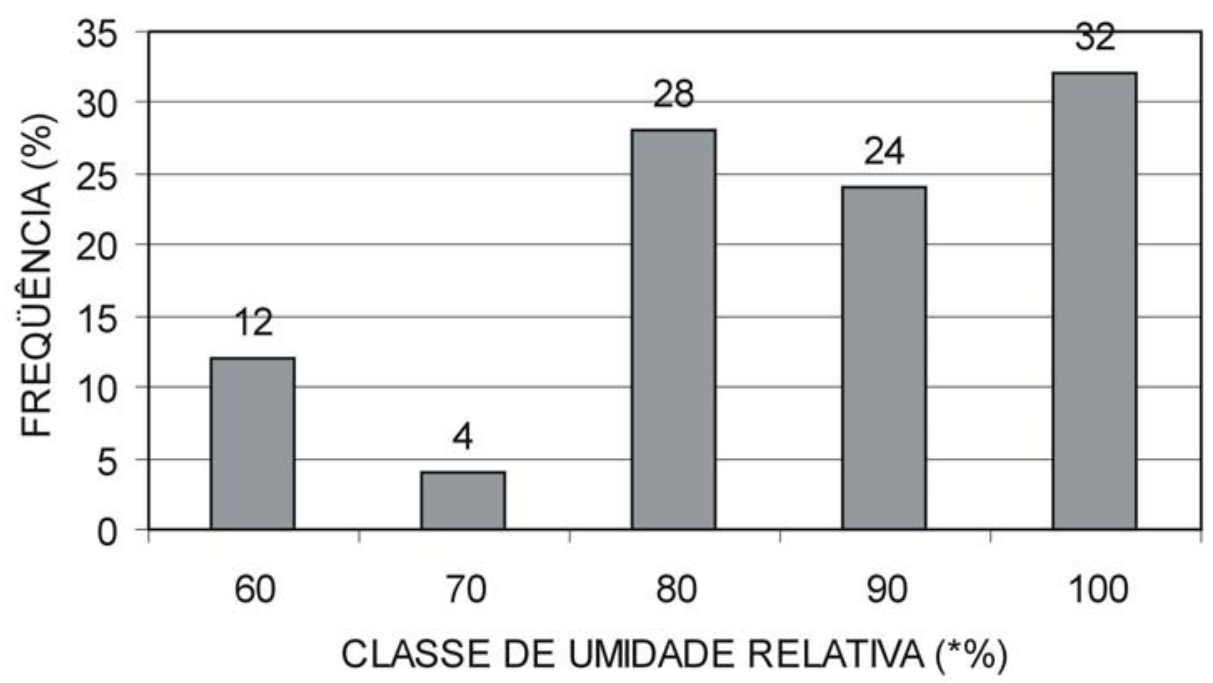

Fonte: Dados registrados em campo (janeiro de 2004).

Reagrupando os pontos de amostragem segundo as cotas altimétricas do Parque Nacional Cavernas do Peruaçu com o objetivo de identificar variações de umidade relativa, foram observados os seguintes aspectos:

Foi mantida a relação proporcional inversa entre os valores de umidade relativa e temperatura para o mês de janeiro de 2004;

Os pontos localizados em cotas entre 440 e 760 metros apresentaram uma taxa média de umidade entre 75 e $80 \%$;

Os pontos localizados nas cotas dentre 500 e 720 e acima dos 760 metros registraram umidades relativas entre 85 e 100 \%; (Gráfico 33).

Considerando as cotas altimétrica e os compartimentos geomorfológicos a elas associados como controles climáticos presentes na área de estudo, estes impõem variações nas condições higrométricas nestes mesmos ambientes que se apresentam com as seguintes características registradas em janeiro de 2004, mostradas na Tabela 09.

Como foi destacado em relação à temperatura, cabe observar que os baixos valores de umidade relativa registrados no compartimento geomorfológico da Depressão do Rio São Francisco estão associados primeiramente aos padrões de uso e formas de ocupação daquele espaço. 
GRÁFICO 33: Umidade relativa média (\%) dos pontos de amostragem distribuída segundo as cotas altimétricas do Parque Nacional Cavernas do Peruaçu (janeiro de 2004).

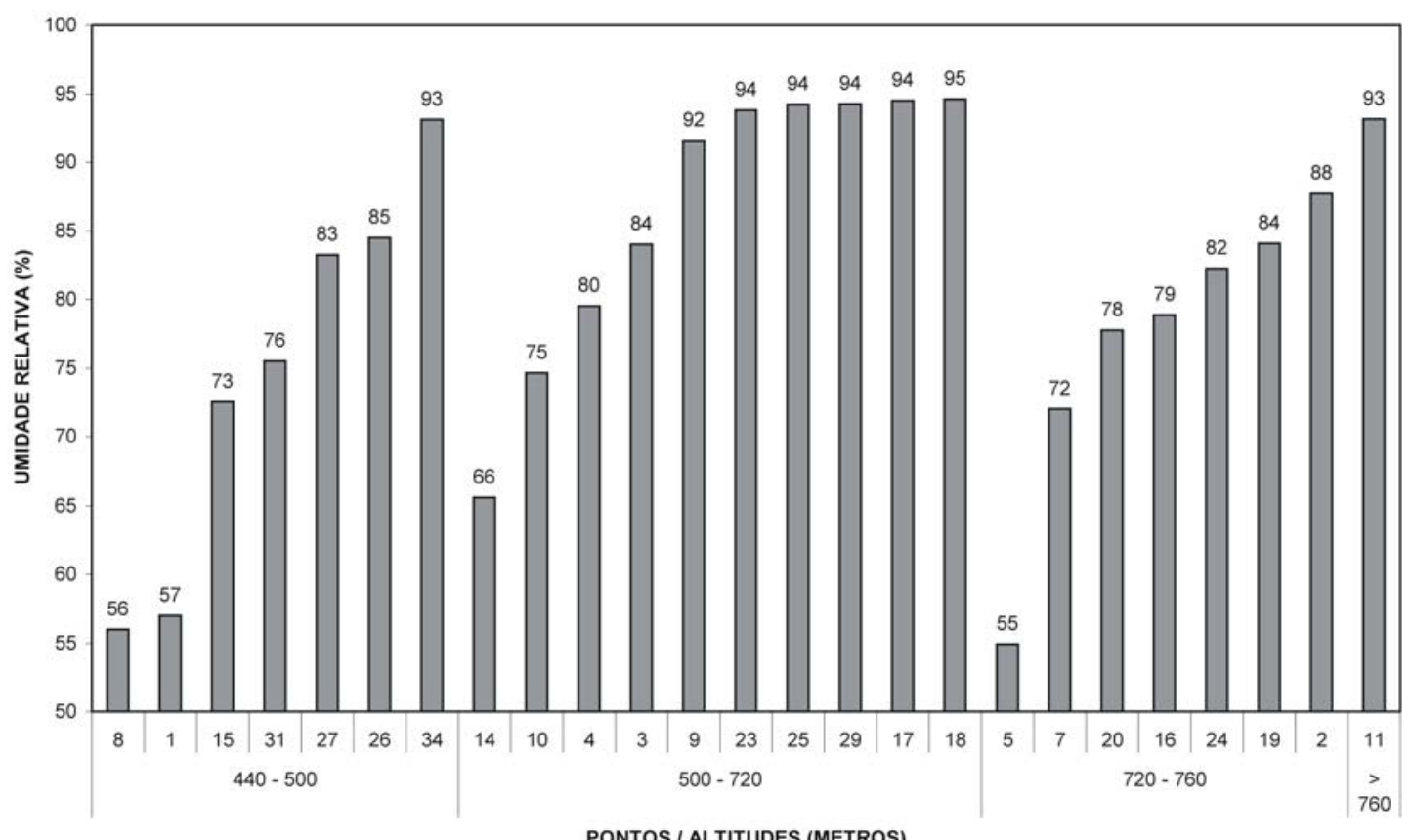

Fonte: Dados registrados em campo (janeiro de 2004).

Visando um melhor entendimento da umidade relativa média registrada em cada compartimento geomorfológico, considerou-se a freqüência de ocorrência dos valores de umidade relativa ali registrados, quando foram observadas as seguintes características:

- O Compartimento Carstificado apresentou-se como o ambiente mais úmido em janeiro de 2004, onde as temperaturas medias dos pontos de amostragem ali localizados apresentaram freqüências de valores próximos de $100 \%$ que respondem por $24 \%$ de toda a amostra. Freqüências entre 4 e $8 \%$ foram identificadas também entre 70 e $90 \%$;

- O Compartimento da Zona de Transição apresentou uma freqüência constante de $8 \%$ em todas as classes de valores de umidade relativa;

- Na Depressão do Rio São Francisco, os valores de umidade relativa são recorrentes próximos a 60,80 a $90 \%$, representando juntas $24 \%$ das amostras;

- No Planalto dos Gerais, os valores de umidade relativa estão concentrados próximos aos 100\% (Gráfico 34). 
TABELA 09: Umidade relativa do ar (\%) segundo os compartimentos geomorfológicos do Parque Nacional Cavernas do Peruaçu (janeiro de 2004).

\begin{tabular}{|c|c|c|}
\hline COMPARTIMENTO GEOMORFOLÓGICO & $\begin{array}{l}\text { PONTO DE } \\
\text { AMOSTRAGEM }\end{array}$ & $\begin{array}{l}\text { UMIDADE } \\
\text { RELATIVA } \\
\text { MÉDIA (\%) }\end{array}$ \\
\hline \multirow{10}{*}{ COMPARTIMENTO CARSTIFICADO } & 14 & 66 \\
\hline & 10 & 75 \\
\hline & 04 & 80 \\
\hline & 03 & 84 \\
\hline & 09 & 92 \\
\hline & 23 & 94 \\
\hline & 25 & 94 \\
\hline & 29 & 94 \\
\hline & 17 & 94 \\
\hline & 18 & 95 \\
\hline \multicolumn{2}{|l|}{ MÉDIA } & 87 \\
\hline \multirow{7}{*}{$\begin{array}{l}\text { COMPARTIMENTO DA DEPRESSÃO DO RIO SÃO } \\
\text { FRANCISCO }\end{array}$} & 08 & 56 \\
\hline & 01 & 57 \\
\hline & 15 & 73 \\
\hline & 31 & 76 \\
\hline & 27 & 83 \\
\hline & 26 & 85 \\
\hline & 34 & 93 \\
\hline \multicolumn{2}{|l|}{ MÉDIA } & 77 \\
\hline \multirow{7}{*}{ COMPARTIMENTO DA ZONA DE TRANSIÇÃO } & 05 & 55 \\
\hline & 07 & 72 \\
\hline & 20 & 78 \\
\hline & 16 & 79 \\
\hline & 24 & 82 \\
\hline & 19 & 84 \\
\hline & 02 & 88 \\
\hline \multicolumn{2}{|l|}{ MÉDIA } & 80 \\
\hline COMPARTIMENTO DO PLANALTO DOS GERAIS & 11 & 65 \\
\hline \multicolumn{2}{|l|}{ MÉDIA } & 93 \\
\hline \multicolumn{2}{|l|}{ MÉDIA TOTAL } & 82 \\
\hline
\end{tabular}

Fonte: Dados registrados em campo (janeiro de 2004).

Mantendo a mesma seqüência de itens abordados na análise climática a seguir as características da umidade relativa registradas nos pontos de amostragem serão considerados sobre os elementos fitológicos e antrópicos enquadrada na escala das geofácies, representadas pelas formações vegetais e ambientes antropogênicos, distintamente.

Sobrepondo os valores médios de umidade relativa do ar sobre as geofácies da Formação Florestal, Savânica, Savânica Estépica e Ambiente Antropogênico verifica-se que, embora o mês de janeiro tenha apresentado valores superiores àqueles registrados em julho, ainda assim os ambientes antropizados em janeiro configuraram-se como o mais seco $(78 \%)$, dentre todos. 
GRÁFICO 34: Distribuição de freqüência (\%) da umidade relativa média (\%) dos pontos de amostragem segundo os compartimentos geomorfológicos do Parque Nacional cavernas do Peruaçu (janeiro de 2004).

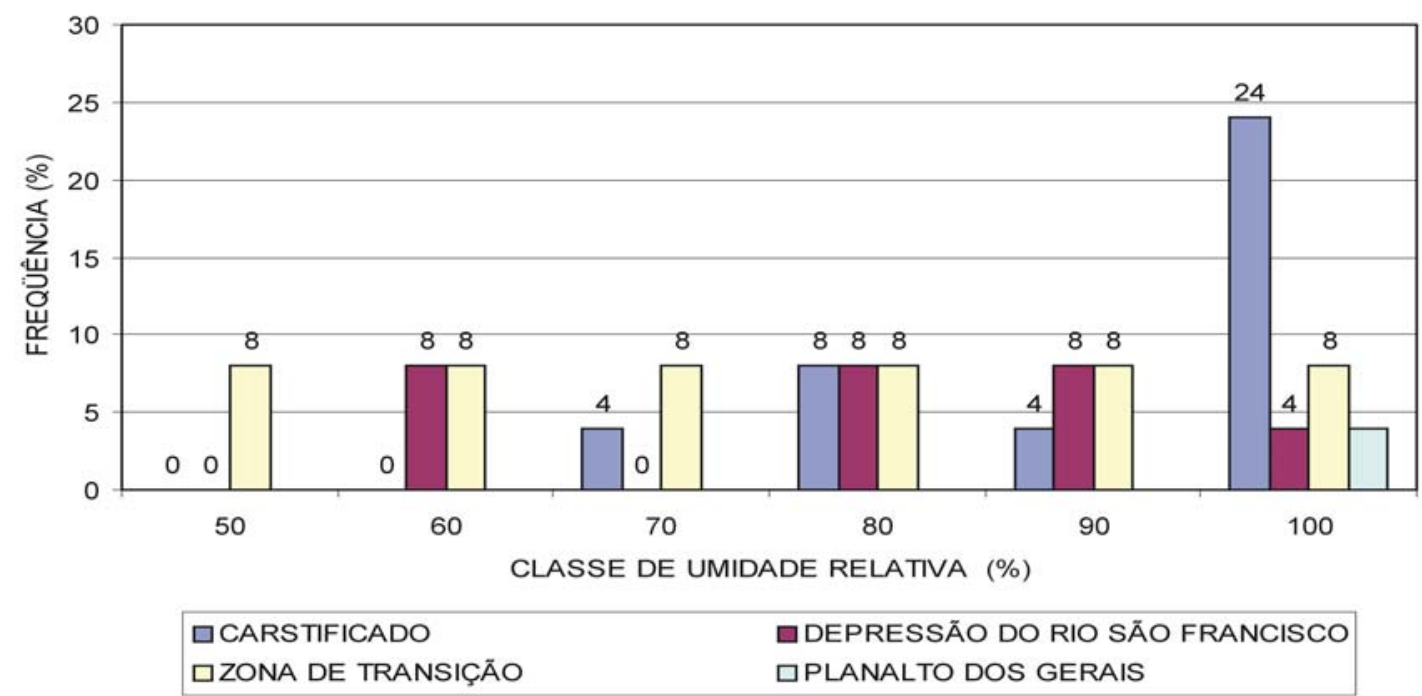

Fonte: Dados registrados em campo (janeiro de 2004).

Para o mesmo período, os ambientes florestados registraram taxas superiores a 80\%, com destaque para as Formações Savânica e Savânica Estépica que registraram as taxas de umidade relativa médias mais elevadas $(88 \% \mathrm{em}$ ambas), como mostram a Tabela 10 e o Gráfico 35.

TABELA 10: Umidade relativa do ar (\%) segundo as formações vegetais e ambientes antropizados do Parque Nacional Cavernas do peruaçu e entorno (janeiro de 2004).

\begin{tabular}{l|c}
\hline \multicolumn{1}{c|}{ FORMAÇÕES VEGETAIS E AMBIENTES ANTROPIZADOS } & $\begin{array}{c}\text { UMIDADE RELATIVA } \\
\text { MÉDIA (\%) }\end{array}$ \\
\hline AMBIENTE ANTROPIZADO & 78 \\
\hline FORMAÇÃO SAVÂNICA ESTÉPICA & 88 \\
\hline FORMAÇÃO FLORESTAL & 88 \\
\hline FORMAÇÃO SAVÂNICA & 82 \\
\hline
\end{tabular}

Fonte: Dados registrados em campo (janeiro de 2004). 
GRÁFICO 35: Umidade relativa média (\%) registrada nas unidades de paisagem das geofácies (janeiro de 2004).

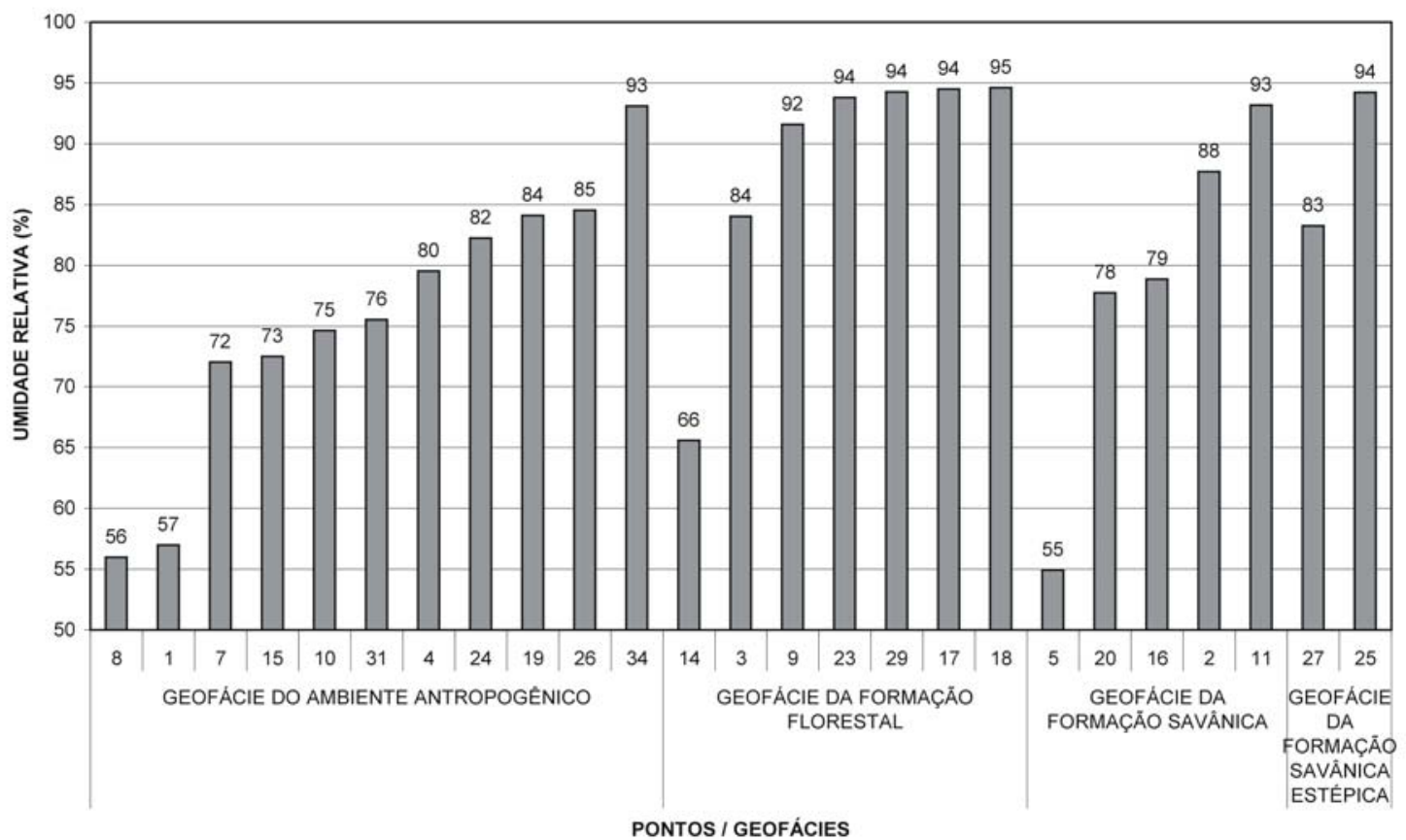

Fonte: Dados registrados em campo (janeiro de 2004).

No âmbito dos Geossistemas, projetando as características higrométricas referentes ao período de janeiro de 2004 sobre as unidades de paisagem enquadradas na escala dos geossistemas, destaca-se o da Depressão do Rio São Francisco registrou umidade relativa de 77\% (médias mínima e máxima de 56 e $96 \%$, respectivamente).

Mesmo em períodos em que a umidade relativa é reconhecidamente mais elevada, as condições verificadas no Geossistema da Depressão do Rio São Francisco ainda refletem as características atmosféricas impostas pelas formas de uso e ocupação do solo predominantes naquela porção.

No Geossistema da Serras da Mãe Joana e do Cardoso de Minas a umidade relativa média foi de $90 \%$ (médias mínima e máxima de 78 e 95\%, respectivamente), enquanto que no Geossistema do Planalto do Rio São Francisco, a umidade relativa foi de 51\% (médias mínima e máxima de 55 e $94 \%$, respectivamente) (Gráfico 36 ).

Observando a distribuição da freqüência das classes de valores de umidade relativa entre os geossistemas apontados neste trabalho, verifica-se que a 0 
Geossistema da Depressão do Rio São Francisco apresenta seus valores de umidade relativa nas freqüências de $60 \%$ e 80 a $100 \%$,

Em relação aos Geossistema das Serras da Mãe Joana e do Cardoso e de Minas, devido à fisionomia vegetal ali predominante apresenta freqüências de valores de umidade relativa entre 80 e 100\%, principalmente com valores próximos aos $100 \%$.

GRÁFICO 36: Umidade relativa média (\%) dos geossistemas do Parque Nacional Cavernas do Peruaçu (janeiro de 2004).

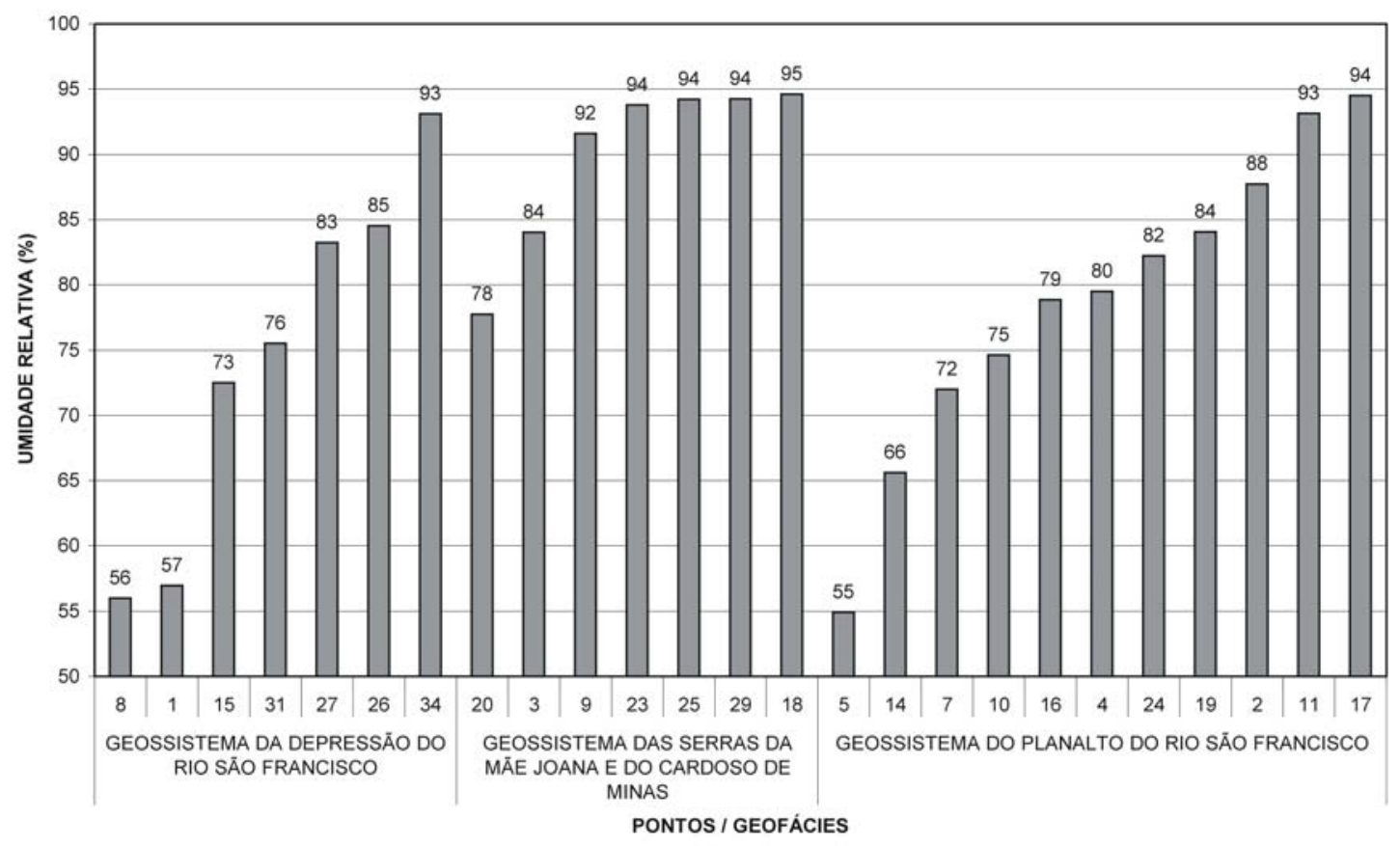

Fonte: Dados registrados em campo (janeiro de 2004).

Considerando as informações sobre as temperaturas obtidas nos pontos de amostragem e unidades de paisagem enquadradas na escala das geofácies e dos geossistemas, a seguir é apresentada a distribuição dos valores médios de umidade relativa do ar sobre a área mapeada no mês de janeiro de 2004, com destaque para o Parque Nacional Cavernas do Peruaçu (Figura 45).

Em linhas gerais, a variação higrométrica do Parque Nacional Cavernas do Peruaçu no mês de janeiro de 2004 oscilou entre 50 e 90\%, registrando as maiores taxas sobre a porção da área de estudo localizadas no compartimento geomorfológico da Depressão do Rio São Francisco, provavelmente recebendo influência da proximidade do próprio rio como da grande quantidade de lagos e várzeas inundadas neste período nesse ambiente. 
Também na porção mais elevada da área de estudo, mais especificamente no trecho mais próximos à Depressão do Rio São Francisco, as taxas de umidade relativa também se mantiveram elevadas (entre 75 e 90\%).

Já nas porções centro/oeste e centro/norte, onde está concentrada parte dos ambientes ocupados pela atividade antrópica, degradados ou mesmo trechos do Compartimento Geomorfológico Carstificado que apresentam uma fisionomia xeromórfica, exemplificado na Figura 44, houve uma variação higrométrica entre 50 e $75 \%$.

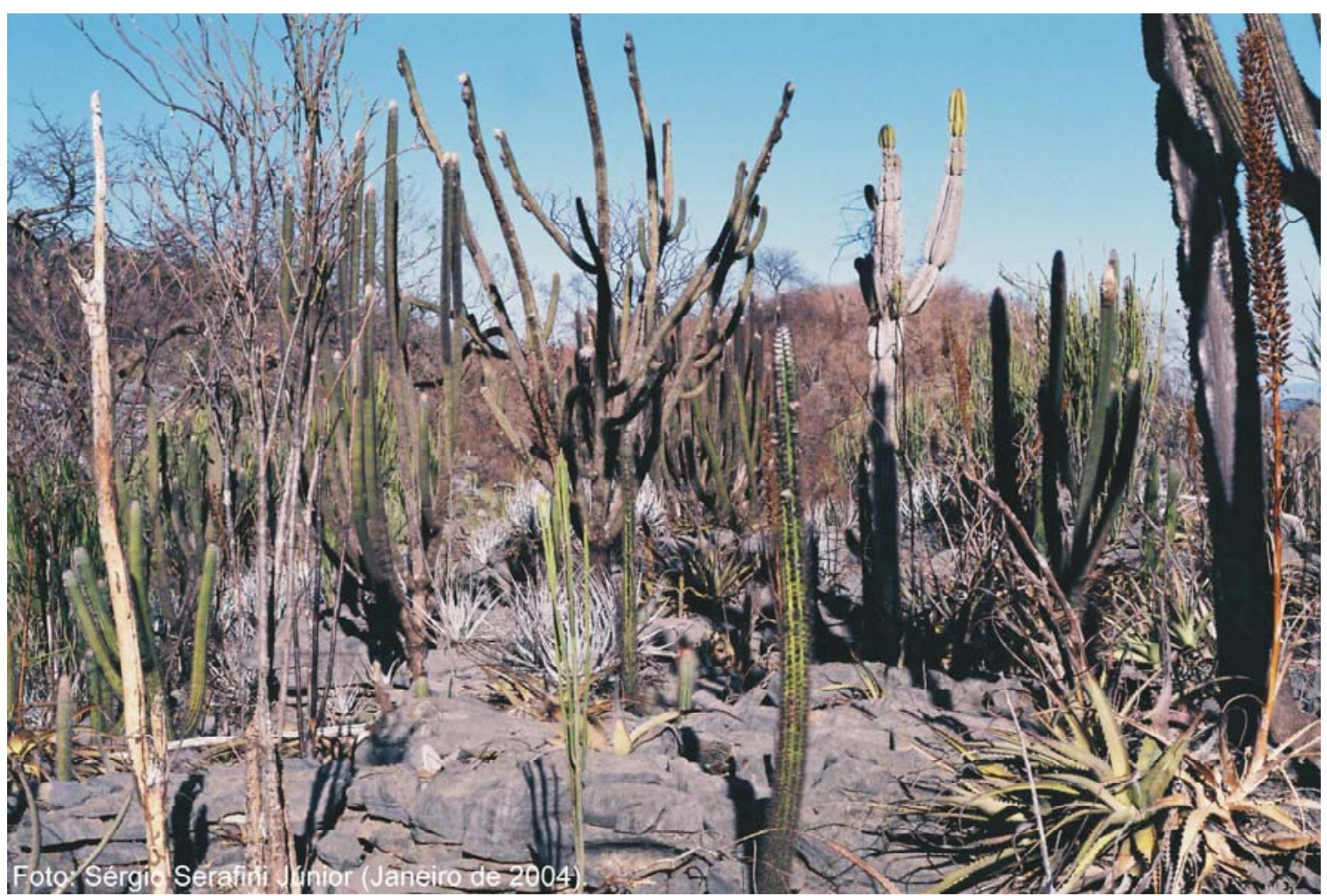

FIGURA 44: Fisionomia xeromórfica encontrada no compartimento geomorfológico carstificado. 


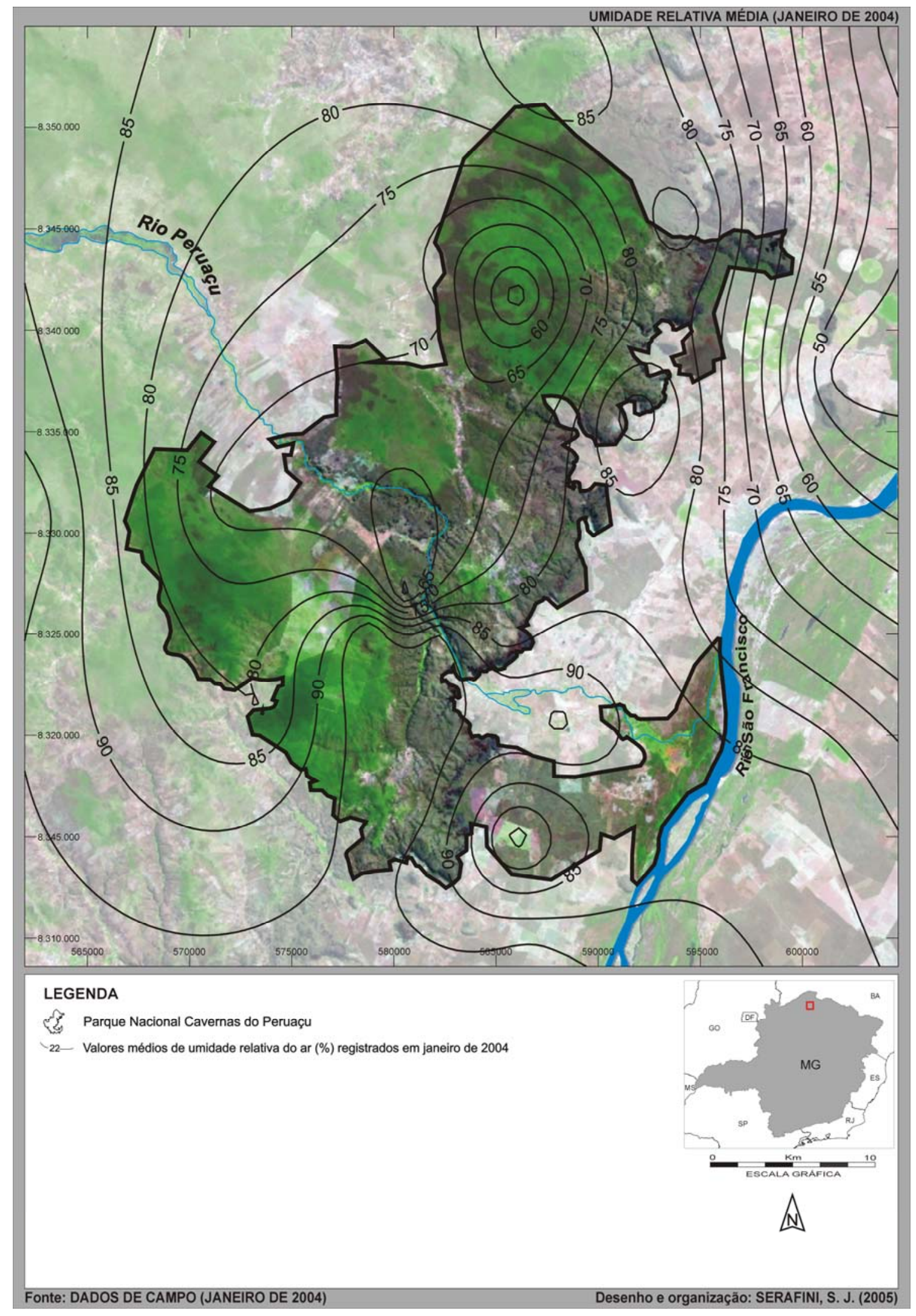

FIGURA 45: Umidade relativa do ar média (\%) do Parque Nacional Cavernas do Peruaçu no mês de janeiro de 2004. 


\section{OS RESULTADOS OBTIDOS}


Uma vez tendo sido apresentados os elementos físicos, bióticos e antrópicos que compõem o perfil fisiográfico da área de estudo, estes foram tratados como referência para a delimitação dos Geossistemas e das Geofácies.

Por sua vez, estas unidades de paisagens foram adotadas como a principal referência para a delimitação das unidades climáticas na escala local do Parque Nacional Cavernas do Peruaçu.

Para isto, a caracterização da temperatura e da umidade relativa do ar foi de extrema importância para o conhecimento detalhado da variação climática destes parâmetros em função dos aspectos fisiográficos de cada ponto de amostragem.

De modo geral, constatou-se que, a variação climática das unidades de paisagens enquadradas na escala dos Geossistemas e Geofácies indicou estar diretamente relacionados, entre outros elementos, aos diferentes tipos de uso e padrões de ocupação do solo; em relação aos quais, as atividades antrópicas mostraram-se como um dos principais agentes modificadores do clima local.

Da mesma forma, as variações climáticas registradas em relação aos tipos de vegetação indicam que a fisionomia diferenciada de cada uma delas interfere nas características climáticas ali predominantes.

Em relação às formações vegetais que foram qualificadas neste trabalho, ficou constatado que quanto maior o porte e mais adensada caracterizava-se a cobertura vegetal, mais baixa eram as temperaturas médias e mais elevadas eram as taxas de umidade relativa do ar, configurando-se assim, como ambientes mais frescos e mais úmidos.

Já, para aquelas fisionomias naturais onde a cobertura vegetal apresenta-se mais aberta e com pouca folhagem, as temperaturas médias apontaram valores mais elevados do que a anterior. Sob as mesmas condições a umidade relativa do ar apresentou valores mais baixos, configurando-se, portanto, em ambientes mais quentes e secos.

Em relação aos ambientes antropizados, notoriamente concentrando-se no Geossistema da Depressão do Rio São Francisco, foi possível identificar preliminarmente um maior aquecimento e redução da umidade relativa do ar, evidenciando condições climáticas de ambientes mais aquecidos e secos. 
Isto posto, em acordo com a proposta deste trabalho e considerando os dados regionais e, principalmente, aqueles registrados no Parque Nacional Cavernas do Peruaçu, as unidades climáticas na escala local foram delimitadas respeitando os mesmos limites sugeridos entre os geossistemas da área de estudo onde estão alojados os controles climáticos que influenciam no comportamento climático na referida escala, permitindo identificar as variações de temperatura e umidade relativa do ar predominantes nesse ambiente.

No âmbito da escala das geofácies, estudos climatológicos nestes ambientes mais detalhados são compatíveis com metodologias mais adequadas à topo e microclimatologia, na qual outros métodos são mais adequados não sendo, portanto, contemplados neste trabalho deixando, portanto, um rico material ainda não trabalhado nesta dissertação, mas que futuramente servirá de fonte para produção científica no formato de artigos em simpósios.

Considerando todos os dados coletados em campo, foi possível definir inicialmente os limites máximos de temperatura e umidade relativa do ar para os meses amostrados, sendo aqui adotados como única referência para a definição das unidades climáticas que estão propostas.

$\mathrm{Na}$ condição de climas locais e arranjados sobre os Geossistemas, as unidades climáticas que os sobrepõem foram igualmente identificados pela referência geomorfológica que referenciou a nomenclatura dos geossistemas adotados neste trabalho, apresentando-se e qualificando-se da seguinte forma:

- Clima local da Depressão do Rio São Francisco:

Para ambos os períodos, a Unidade Climática da Depressão do Rio São Francisco mantém-se como o mais aquecido, apresentando temperaturas médias que variaram entre 25 e $32^{\circ} \mathrm{C}$ em janeiro e 26 e $27^{\circ} \mathrm{C}$ em julho.

Em relação à umidade relativa do ar, nesta unidade climática, igualmente proporcional os valores são os mais baixos da área de estudo, variando entre 37 e $58 \%$ em julho e 55 a $94 \%$ em janeiro.

- Clima local das Serras da Mãe Joana e do Cardoso de Minas

Em função das características fisionômicas que predominam nesta unidade climática local serem semelhantes com aquela encontrada no 
Geossistema do Planalto do Rio São Francisco, as variações climáticas também ocorrem de forma muito semelhantes em relação à unidade climática que foi delimitada sobre aquele Geossistema.

No mês de janeiro, as temperaturas variam entre 24 e $26^{\circ} \mathrm{C}$, enquanto que em julho a variação fica em torno de 15 a $24^{\circ} \mathrm{C}$

A umidade relativa para os mesmos períodos apresenta variações entre 78 a $95 \%$ no mês de janeiro e 42 a $70 \%$ em julho

- Clima local do Planalto do Rio São Francisco

Nesta unidade climática local, a temperatura em janeiro apresenta oscilacão entre 23 e $29^{\circ} \mathrm{C}$ e 21 a $25^{\circ} \mathrm{C}$ em julho, enquanto que a umidade relativa ficou entre 56 e $93 \%$ e 38 a 65 , respectivamente para os mesmos períodos.

A seguir, na Figura 46, são apresentadas as unidades climáticas locais do Parque Nacional Cavernas do Peruaçu, conforme havia sido proposto no início deste trabalho. 


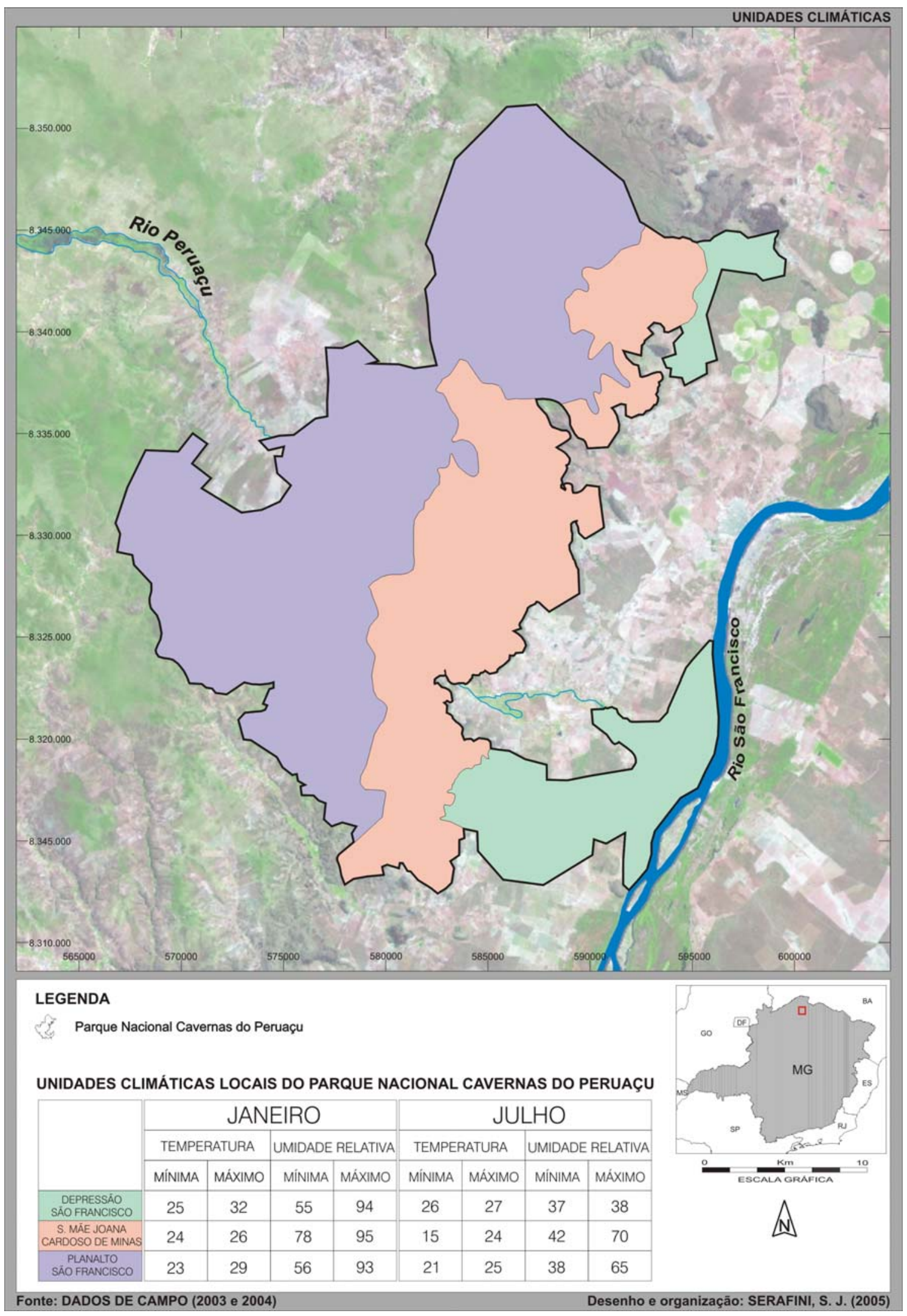

FIGURA 46: Unidades climáticas locais do Parque Nacional Cavernas do Peruaçu. 
DELIMITAÇÃO DE UNIDADES CLIMÁTICAS LOCAIS NO PARQUE NACIONAL CAVERNAS DO PERUAÇU (VERSÃO REVISADA)

\section{AS CONSIDERAÇÕES FINAIS}


Em linhas gerais, o Parque Nacional Cavernas do Peruaçu reúne diferentes tipos de paisagens representados, predominantemente, por áreas naturais remanescentes, áreas degradadas por processos naturais e áreas antropizadas, sobre as quais está associado o comportamento climático local.

Durante os trabalhos de campo foram observados alguns problemas relacionados à manutenção dessa Unidade de Conservação de ordem natural e antrópica.

Em relação aos problemas naturais identificados, estes estão associados à variação climática da área de estudo no que diz respeito aos baixos totais pluviométricos médios registrados entre 1961 e 1990, proporcionando um quadro de estiagem favorável às queimadas, muito comuns no período de inverno na porção central do Brasil.

Com relação aos problemas originados pelas alterações antrópicas, o principal deles identificado é a elevada temperatura e reduzida umidade relativa do ar, sobretudo em áreas que apresentaram maior grau de antropização (ambientes antropogênicos) indicando, portanto, que as atividades antrópicas são elementos condicionantes na alteração climática na área de estudo.

Os ambientes antropogênicos reúnem diferentes tipos de padrões de uso e ocupação do solo, sobretudo, atividades agropastoris em substituição às áreas com cobertura vegetal natural por elementos exóticos à paisagem natural, como, por exemplo, as pastagens e as áreas urbanizadas.

Basicamente, esses estão presentes em grande parte do entorno da área de estudo, desde a porção do alto rio Peruaçu, até sua foz no rio São Francisco, onde predominam as pastagens e as áreas urbanizadas, sobre as quais foram registrados ambientes, predominantemente quentes e secos, acima da média registrada em outros ambientes do Parque Nacional Cavernas do Peruaçu.

No âmbito das unidades climáticas locais do Parque Nacional Cavernas do Peruaçu, destaca-se aquela da Depressão do Rio São Francisco que pela suas características fisionômicas associadas à intensa atividade humana ali presente, foi interpretado como um ambiente que exerce relativa pressão térmica sobre o geossistema vizinho (das Serras da Mãe Joana e do Cardoso de Minas), principalmente sobre a faixa mais próxima ao primeiro geossistema. 
Assim, considerando que a dinâmica de ocupação da região de estudo vem indicando uma tendência expansionista das áreas destinadas para uso agropecuário com redução das áreas ainda preservadas; e que a extensão destas áreas dentro do Parque Nacional Cavernas do Peruaçu é crítico, é possível inferir que as características climáticas dessas áreas antropizadas estejam influenciando o comportamento climático de áreas naturais preservadas através de um provável efeito de borda ali atuante sobre ambientes mais frescos e mais úmidos.

Com isto, justifica-se a realização deste trabalho de entendimento do comportamento climático local do Parque Nacional Cavernas do Peruaçu na perspectiva de delimitação de unidades climáticas permitindo, a partir de então, a realização de um trabalho de monitoramento e obtenção de resultados que evidenciem $\mathrm{o}$ avanço das áreas antropizadas sobre as naturais $\mathrm{e}$ consequentemente dos climas locais predominantes em cada um dos geossistemas. 
DELIMITAÇÃO DE UNIDADES CLIMÁTICAS LOCAIS NO PARQUE NACIONAL CAVERNAS DO PERUAÇU 
AB' SABER, Aziz Nacib, Províncias geológicas e domínios morfoclimáticos no Brasil, Caderno Geomorfologia, n 20, Universidade de São Paulo, Instituto de Geografia, São Paulo, 1970.

ARANHA, Maria Lúcia de, Filosofando: Introdução à filosofia, São Paulo, Ed. Moderna, 1986.

ASSIS, Francisco Neto de et Alii. Aplicações de estatística à climatologia: Teoria e prática, Ed. Universitária, UFPel, Pelotas, 1996.

AYOADE, J. O. Introdução à climatologia para os trópicos, Ed. Bertrand Brasil, $3^{a}$ edição, Rio de Janeiro / RJ, 1990.

BERTRAND, G. Paisagem e geografia física global: esboço metodológico, Caderno de Ciências da Terra, $n^{\circ}$. 13, Universidade de São Paulo, Instituto de Geografia, São Paulo, 1971.

CASTILHO, Ricardo. A imagem de satélite como estatística da paisagem, Revista Ciência Geográfica: ensino, pesquisa, método, Associação dos Geógrafos do Brasil, $n^{\circ}$. 01, Bauru, SP, 1995.

CONTI, José Bueno, Desertificação nos trópicos: proposta metodológica de estudo aplicada ao nordeste brasileiro, Tese de Livre-Docência, Universidade de São Paulo, Departamento de Geografia, São Paulo, 1995.

CRISTOFOLETTI, Antonio, Caracterização do sistema ambiental, Rio Claro, SP, 1997, texto Mimeografado (Texto retirado de: SOARES, Fátima Maria, Unidades do relevo como proposta de classificação das paisagens da bacia do rio Curú Estado do Ceará - pág.10 - Veja na Bibliografia).

DELPOUX, Marcel. Ecossistema e paisagem, In: Método em questão, Tradução: May Christine Modenesi, Instituto de Geografia, Universidade de São Paulo, São Paulo, 1974.

FOLHA DE SÃO PAULO, Atlas geográfico mundial, 2ª edição, São Paulo, Ed. Empresa Folha da Manhã S.A., 1994.

FORSDYKE, A. G. Previsão do tempo e clima, São Paulo, Melhoramentos, Edusp, série prisma $\mathrm{n}^{\circ} 17$, , 1975.

FURLAN, Sueli Angelo \& CARBONARI, Marli Penteado. Guia para trabalho de campo e biogeografia, Texto de aula, DG - USO, s/d.

GALVANI, Emerson, Considerações acerca dos estudos bioclimáticos, Anais do X Encontro de Geógrafos da América Latina, EGAL, 20 a 26 de março de 2005, Universidade de São Paulo. 
GEORGE, Pierre. Os métodos da Geografia, São Paulo, Ed. Difel, 1972.

GLADFELTER, B.G. Developments and directions in geoarchaeology, Trad. Marisa Coutinho Afonso, IN: Advances in archaeology method and theory, M.B. Shiffer, Vol. 4, New York: Academic Press, 1981.

INSTITUTO BRASILEIRO DE GEOGRAFIA E ESTATÍSTICA - IBGE, Manual técnico de geomorfologia, Manual técnico em geociências - nº 5, Rio de Janeiro, 1995. INSTITUTO BRASILEIRO DO MEIO AMBIENTE E DOS RECURSOS NATURAIS RENOVÁVEIS - IBAMA, Plano de Manejo do Parque Nacional Cavernas do Peruaçu, Brasília - DF, 2005.

INSTITUTO BRASILEIRO E GEOGRAFIA E ESTATÍSTICA - IBGE, Mapa de biomas do Brasil: primeira aproximação, Escala 1:5.000.000, 2004.

INSTITUTO NACIONAL DE METEOROLOGIA, Normais climatológicas: 1961/1990, Brasília - DF, 1992.

INSTITUTO NACIONAL DE PESQUISAS ESPACIAIS - INPE, Climanálise: boletim de monitoramento e análise climática, volume 18, nº. 07, julho de 2003.

INSTITUTO NACIONAL DE PESQUISAS ESPACIAIS - INPE, Climanálise: boletim de monitoramento e análise climática, volume 19, nº 01 janeiro de 2004.

INSTITUTO NACIONAL DE PESQUISAS ESPACIAIS - INPE, Tutorial 10 aulas: SPRING 3.6 (versão Windows / UNIX), SPRING básico, INPE, São José dos Campos, março de 2002.

LANDSAT TM 7. São José dos Campos: Instituo Nacional de Pesquisas Espaciais, 2003. Imagem de satélite. Canais 3, 4 e 5. Escala 1:100.000

LEITE, Ângela Faggin Pereira, Análise geossistêmica em geografia como subsídio ao planejamento paisagístico, Dissertação de Mestrado, Universidade de São Paulo, Departamento de Geografia, Orientador Prof. Dr. Carlos Augusto de Figueiredo Monteiro, São Paulo, 1983.

LLOYDS BANK, Cerrados vastos espaços: flora e fauna do Brasil Central, Edições Alumbramento, Rio de Janeiro, 1992/93.

MONTEIRO, Carlos Augusto de Figueiredo. A dinâmica climática e as chuvas no Estado de São Paulo, Laboratório de climatologia, Instituto de Geografia, Universidade de São Paulo, São Paulo, 1973.

MONTEIRO, Carlos Augusto de Figueiredo. A Frente Polar Atlântica e as chuvas de inverno na fachada sul-oriental do Brasil - Contribuições metodológicas à análise 
rítmica dos tipos de tempo no Brasil, Série teses e Monografia n' 01, USP-IG, São Paulo/SP, 1969.

MONTEIRO, Carlos Augusto de Figueiredo. Derivações antropogênicas dos geossistemas terrestres no Brasil e alterações climáticas: perspectivas urbanas e agrárias ao problema da elaboração de modelos de avaliação, Universidade de São Paulo, Instituto de Geografia, São Paulo, s/d.

MOURA, Maria Teresa Teixeira de. A evolução do sítio arqueológico Lapa do Boquete na paisagem cárstica do Vale do Peruaçu: Januária (MG), Dissertação de Mestrado, Universidade de São Paulo, Departamento de Geografia, São Paulo, 1997.

NOVO, Evelyn Moraes, Sensoriamento remoto: princípios e aplicações, Ed. Edgard Blücher Ltda, São Paulo / SP, 1989.

PROUS, André, O povoamento da América visto do Brasil: Uma perspectiva crítica, Revista USP nº. 34, São Paulo, 1997.

RENFREW, Colin, Archaeology and the earth sciences, In: Geoarchaeology: earth science and past, Ed. D. A. DAVIDSON and M. L. SHACKLEY, M., Boulder, Co: Westwiew Press, Tradução de Marisa Coutinho Afonso, DG-USP, 1976. (P.1)

ROSS, Jurandir L. Sanches, Os fundamentos da geografia da natureza, In: Geografia do Brasil, São Paulo, Edusp, 1995.

SALVADOR, A. D., Métodos e técnicas da pesquisa bibliográfica: elaboração de trabalhos científicos, Porte Alegre / RS, Ed. Sulinas, p. 13 a 21, 1986.

SANT'ANNA NETO, J. L \& ZAVATINI, J.A., Variabilidade e Mudanças Climáticas: Implicações Ambientais e Socioeconômicas, Maringá: Eduem, 2000,

SCHOBBENHAUS, C. et alii, Geologia do Brasil, Brasília, DNPM, 1984.

SERAFINI, Sérgio Júnior, Busca de Evidencia do Fenômeno Ilha de Calor num Loteamento Clandestino Localizado em Área de Mananciais: Caso Núcleo Santa Cruz, Trabalho de Graduação Individual, Universidade de São Paulo, Faculdade de Filosofia, Letras e Ciências Humanas, Departamento de Geografia, São Paulo, 2000.

SERAFINI, Sérgio Júnior, Distribuição das chuvas no Estado de Minas Gerais com destaque para sua porção norte e Município de Itacarambi, II Seminário de Pesquisa em Geografia Física - Programa de Pós-graduação em Geografia Física - USP, 2004. 
SILVA, Armando Corrêa. Notas sobre o método científico e a observação em Geografia, Métodos em Questão, Tribuna metodológica, Instituto de Geografia, Universidade de São Paulo, São Paulo, 1971.

SOARES, Fátima Maria, Unidades do relevo como proposta de classificação das paisagens da bacia do rio Curu - Estado do Ceará, Dissertação de mestrado, Universidade de São Paulo, Faculdade de Filosofia, Letras e Ciências Humanas, Departamento de Geografia, Orientador: Prof. Dr. Adilson Avansi de Abreu, São Paulo, 2001.

SORRE, Max, Traité de climatologie biologique et médicale, Org. Piery Masson, Tradução de José Bueno Conti, Cie Editeurs, Paris, 1934. (Texto separado do original para discussão em sala de aula).

SPRING: Integrating remote sensing and GIS by object-oriented data modelling" Camara G, Souza RCM, Freitas UM, Garrido J Computers \& Graphics, 20: (3) 395403, May-Jun 1996.

TRICART Jean L. F., Paisagem e ecologia, texto provisório da tradução do original francês feita pelo Prof. Dr. Carlos Augusto Figueiredo Monteiro, Instituto de Geografia da Universidade de São Paulo, São Paulo, 1981. 


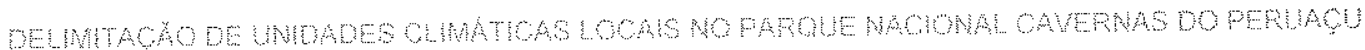
Mersa REVAMDA

sargib Sertin who

\section{ANEXOS}


ANEXO A: ESTAÇÕES METEOROLÓGICAS DO INMET DE MINAS GERAIS.

\begin{tabular}{|c|c|c|c|c|c|}
\hline NOME & CÓDIGO OMM & LAT (S) & LONG & $\begin{array}{l}\text { ALTITUDE } \\
\text { (METROS) }\end{array}$ & PERIOODO \\
\hline Aimorés & 83595 & $19^{\circ} 29^{\prime}$ & $41^{\circ} 04^{\prime}$ & 82,74 & $73 / 90$ \\
\hline Araçuaí & 83442 & $16^{\circ} 52^{\prime}$ & $42^{\circ} 04^{\prime}$ & 284,39 & $70 / 90$ \\
\hline Araxá & 83579 & $19^{\circ} 34^{\prime}$ & $46^{\circ} 56^{\prime}$ & 1003,87 & $71 / 90$ \\
\hline Bambui & 83582 & $20^{\circ} 00^{\prime}$ & $45^{\circ} 59^{\prime}$ & 661,27 & $72 / 90$ \\
\hline Barbacena & 83698 & $21^{\circ} 15^{\prime}$ & $43^{\circ} 46^{\prime}$ & 1126,00 & $61 / 90$ \\
\hline Belo Horizonte & 83587 & $19^{\circ} 56^{\prime}$ & $43^{\circ} 56^{\prime}$ & 850,02 & $61 / 90$ \\
\hline Conc. Mato Dentro & 83589 & $19^{\circ} 02^{\prime}$ & $43^{\circ} 26^{\prime}$ & 652,00 & $71 / 90$ \\
\hline Caparaó & 83639 & $20^{\circ} 31^{\prime}$ & $41^{\circ} 52^{\prime}$ & 843,18 & $73 / 90$ \\
\hline Capinópolis & 83514 & $18^{\circ} 41^{\prime}$ & $49^{\circ} 34^{\prime}$ & 620,60 & $74 / 90$ \\
\hline Caratinga & 83592 & $19^{\circ} 48^{\prime}$ & $42^{\circ} 09^{\prime}$ & 609,05 & $71 / 90$ \\
\hline Cataguases & 83027 & $21^{\circ} 23^{\prime}$ & $42^{\circ} 41^{\prime}$ & 167,98 & $61 / 79$ \\
\hline Cel. Pacheco & 83037 & $21^{\circ} 35^{\prime}$ & $43^{\circ} 15^{\prime}$ & 435,00 & $65 / 90$ \\
\hline Diamantina & 83583 & $18^{\circ} 15^{\prime}$ & $43^{\circ} 36^{\prime}$ & 1296,12 & $72 / 90$ \\
\hline Espinosa & 83338 & $14^{\circ} 55^{\prime}$ & $42^{\circ} 51^{\prime}$ & 569,84 & $74 / 90$ \\
\hline Gov. Valadares & 83543 & $18^{\circ} 51^{\prime}$ & $41^{\circ} 56^{\prime}$ & 277,45 & $67 / 90$ \\
\hline Ibirité & 83632 & $20^{\circ} 01^{\prime}$ & $44^{\circ} 03^{\prime}$ & 814,54 & $61 / 90$ \\
\hline Itamarandiba & 83488 & $17^{\circ} 51^{\prime}$ & $42^{\circ} 51^{\prime}$ & 1097,00 & $63 / 90$ \\
\hline João Pinheiro & 83481 & $17^{\circ} 42^{\prime}$ & $46^{\circ} 10^{\prime}$ & 760,36 & $61 / 90$ \\
\hline Juiz de Fora & 83692 & $21^{\circ} 46^{\prime}$ & $43^{\circ} 21^{\prime}$ & 939,96 & $73 / 90$ \\
\hline Lavras & 83687 & $21^{\circ} 14^{\prime}$ & $45^{\circ} 00^{\prime}$ & 918,84 & $65 / 90$ \\
\hline Machado & 83683 & $21^{\circ} 40^{\prime}$ & $45^{\circ} 55^{\prime}$ & 873,35 & $61 / 90$ \\
\hline Monte Azul & 83388 & $15^{\circ} 05^{\prime}$ & $42^{\circ} 45^{\prime}$ & 603,63 & $75 / 90$ \\
\hline Montes Claros & 83437 & $16^{\circ} 43^{\prime}$ & $43^{\circ} 52^{\prime}$ & 646,29 & $69 / 90$ \\
\hline Paracatu & 83479 & $17^{\circ} 13^{\prime}$ & $46^{\circ} 52^{\prime}$ & 711,40 & $74 / 90$ \\
\hline Patos de Minas & 83531 & $18^{\circ} 36^{\prime}$ & $46^{\circ} 31^{\prime}$ & 940,28 & $61 / 90$ \\
\hline Pedra Azul & 83393 & $16^{\circ} 00^{\prime}$ & $41^{\circ} 17^{\prime}$ & 648,91 & $73 / 90$ \\
\hline Pompeu & 83570 & $19^{\circ} 13^{\prime}$ & $45^{\circ} 00^{\prime}$ & 690,91 & $73 / 90$ \\
\hline São Lourenço & 83736 & $22^{\circ} 06^{\prime}$ & $45^{\circ} 01^{\prime}$ & 900,32 & $61 / 90$ \\
\hline Sete Lagoas & 83586 & $19^{\circ} 28^{\prime}$ & $44^{\circ} 15^{\prime}$ & 732,00 & $61 / 90$ \\
\hline Teófilo Otoni & 83492 & $17^{\circ} 51^{\prime}$ & $41^{\circ} 31^{\prime}$ & 356,38 & $70 / 90$ \\
\hline Uberaba & 83577 & $19^{\circ} 45^{\prime}$ & $47^{\circ} 55^{\prime}$ & 742,90 & $61 / 90$ \\
\hline Viçosa & 83642 & $20^{\circ} 45^{\prime}$ & $42^{\circ} 51^{\prime}$ & 689,73 & $61 / 90$ \\
\hline
\end{tabular}


ANEXO B: ESTAÇÕES METEOROLÓGICAS DOS ESTADOS DA BAHIA, ESPÍRITO SANTO, RIO DE JANEIRO, SÃO PAULO, MATO GROSSO DO SUL, GOIÁS E DISTRITO FEDERAL E MAIS PRÓXIMAS À MINAS GERAIS.

\begin{tabular}{|c|c|c|c|c|c|c|}
\hline UF & NOME & CODIGO OMM & LAT (S) & LONG & $\begin{array}{l}\text { ALTITUDE) } \\
\text { (METROS) }\end{array}$ & PERIODO \\
\hline \multirow{3}{*}{ BA } & Caetité & 83339 & $14^{\circ} 03^{\prime}$ & $42^{\circ} 37^{\prime}$ & 882,47 & $61 / 90$ \\
\hline & Guaratinga & 83446 & $16^{\circ} 44^{\prime}$ & $39^{\circ} 44^{\prime}$ & 323,75 & $61 / 90$ \\
\hline & Vit. da Conquista & 83344 & $15^{\circ} 57^{\prime}$ & $40^{\circ} 53^{\prime}$ & 839,00 & $61 / 90$ \\
\hline DF & Brasilia & 83377 & $15^{\circ} 47^{\prime}$ & $47^{\circ} 56^{\prime}$ & 1159,54 & $63 / 90$ \\
\hline \multirow{4}{*}{ ES } & Cach. Itapemírim & 83646 & $20^{\circ} 51^{\prime}$ & $41^{\circ} 06^{\prime}$ & 77,53 & $61 / 90$ \\
\hline & Linhares & 83597 & $19^{\circ} 24^{\prime}$ & $40^{\circ} 04^{\prime}$ & 28,40 & $70 / 90$ \\
\hline & São Mateus & 83550 & $18^{\circ} 42^{\prime}$ & $39^{\circ} 51^{\prime}$ & 25,04 & $71 / 90$ \\
\hline & Vitória & 83648 & $20^{\circ} 19^{\prime}$ & $40^{\circ} 20^{\prime}$ & 36,30 & $61 / 90$ \\
\hline \multirow{3}{*}{ GO } & Catalão & 83526 & $18^{\circ} 11^{\prime}$ & $47^{\circ} 57^{\prime}$ & 840,47 & $61 / 90$ \\
\hline & Formosa & 83379 & $15^{\circ} 32^{\prime}$ & $47^{\circ} 20^{\prime}$ & 912,00 & $61 / 90$ \\
\hline & Posse & 83332 & $14^{\circ} 06^{\prime}$ & $46^{\circ} 22^{\prime}$ & 825,64 & $76 / 90$ \\
\hline \multirow{2}{*}{ MS } & Paranaíba & 83565 & $19^{\circ} 42^{\prime}$ & $51^{\circ} 11^{\prime}$ & 331,25 & $71 / 90$ \\
\hline & Três Lagoas & 83618 & $20^{\circ} 47^{\prime}$ & $51^{\circ} 42^{\prime}$ & 313,00 & $61 / 90$ \\
\hline \multirow{4}{*}{ RJ } & Cordeiro & 83718 & $22^{\circ} 02^{\prime}$ & $42^{\circ} 22^{\prime}$ & 484,68 & $72 / 90$ \\
\hline & Itaperuna & 83695 & $21^{\circ} 12^{\prime}$ & $41^{\circ} 53^{\prime}$ & 123,59 & $69 / 90$ \\
\hline & Nova Friburgo & 83745 & $22^{\circ} 17^{\prime}$ & $42^{\circ} 32^{\prime}$ & 856,60 & $61 / 90$ \\
\hline & Piraí & 83757 & $22^{\circ} 38^{\prime}$ & $43^{\circ} 54^{\prime}$ & 366,65 & $61 / 90$ \\
\hline \multirow{6}{*}{$\mathrm{SP}$} & Campos do Jordão & 83714 & $22^{\circ} 44^{\prime}$ & $45^{\circ} 35^{\prime}$ & 1578,81 & $61 / 90$ \\
\hline & Catanduva & 83676 & $21^{\circ} 08^{\prime}$ & $48^{\circ} 58^{\prime}$ & 536,00 & $61 / 90$ \\
\hline & Franca & 83630 & $20^{\circ} 33^{\prime}$ & $47^{\circ} 26^{\prime}$ & 1026,20 & $61 / 90$ \\
\hline & São Carlos & 83726 & $22^{\circ} 01^{\prime}$ & $47^{\circ} 53^{\prime}$ & 856,00 & $61 / 90$ \\
\hline & São Paulo & 83781 & $23^{\circ} 3^{\prime}$ & $46^{\circ} 37^{\prime}$ & 792,60 & $61 / 90$ \\
\hline & São Simão & 83669 & $21^{\circ} 29^{\prime}$ & $47^{\circ} 33^{\prime}$ & 617,39 & $78 / 89$ \\
\hline
\end{tabular}

Fonte: INMET, 1992 
ANEXO C: AUTORIZAÇÃO DO IBAMA PARA REALIZAÇÃO DE TRABALHO DE CAMPO EM JULHO DE 2003 (cópia digitalizada).

Instituto Brasileiro do Meio ambiente e dos Recursos Naturais Renováveis Gerencia Executiva do Estado De Minas Gerais APA/PARNA Cavernas do Peruaçu

Januária, 17 de junho de 2003

Oficio $n^{0} 023 / 03$

Do: Gerente da APA Cavernas do Peruaçu - IBAMAMG

À: Universidade de São Paulo

Faculdade de Filosofia, Letras e Ciências Humanas

Departamento de Geografia/ Setor de Pós Graduaça

a/c Sr. Prof.' Dr. José Bueno Conti

Assunto: Autorização para acesso ao PARNA Cavernas do Peruaçu

Ao cumprimentá-lo, e em resposta à correspondência de 01/05/2003, informo que o aluno Sérgio Serafini Júnior, $\mathbf{n}^{0}$ USP 1973554, estâ autorizado a acessar as dependências do Parque Nacional Cavernas do Peruacu no período de $29 / 06$ a 17/07/2003 para dar continuidade à sua pesquisa acadếmica.

Atenciosamente,

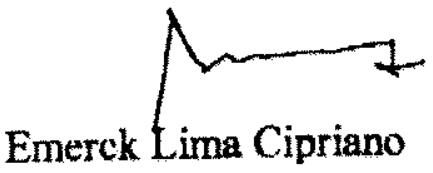

Gerente da APA Cavernas do Peruaçu 


\section{ANEXO D: AUTORIZAÇÃO DO IBAMA PARA REALIZAÇÃO DE TRABALHO DE CAMPO EM JANEIRO DE 2004 (cópia digitalizada).}

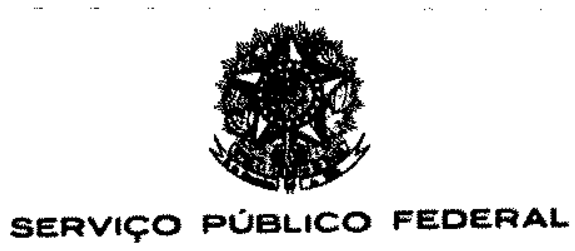

Instituto Brasileiro do Meio ambiente e dos Recursos Naturais Renováveis Gerência Executiva do Estado De Minas Gerais

PARNA Cavernas do Peruaçu

Januária, 05 de janeiro de 2004

Oficio $n^{\circ} 008 / 04$

Do: Gerente do PARNA Cavernas do Peruaçu - IBAMA/MG

$\dot{A}$ : Universidade de São Paulo

Faculdade de Filosofia, Letras e Cièncias Humanas

Departamento de Geografia/ Setor de Pós Graduação

a/c Sr. Prof. Dr. José Bueno Conti

Assunto: Autorização para acesso ao PARNA Cavernas do Peruaçu

Ao cumprimentá-lo, e em resposta à correspondência de 01/05/2003, informo que o aluno Sérgio Serafini Júnior, matricula $\mathrm{n}^{\circ}$ 1973554, está autorizado a acessar as dependências do Parque Nacional Cavernas do Peruaçu no periodo de 05/01 a 05/02/2004, para dar continuidade à sua pesquisa acadêmica.

Atenciosamente,

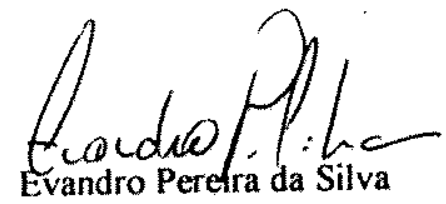

Gerente do PARNA Cavernas do Peruaçu

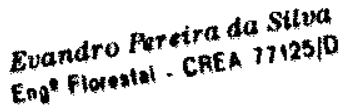




\section{ANEXO E: DECRETO DE CRIAÇÃO DA APA CAVERNAS DO PERUAÇU}

DECRETO N 98.182, DE 26 DE SETEMBRO DE 1989.

Dispõe sobre a criação de área de proteção ambiental no Estado de Minas Gerais, e dá outras providências.

O PRESIDENTE DA CAMMARA DOS DEPUTADOS, no exercício do cargo de PRESIDENTE DA REPÚBLICA, no uso das atribuições que the confere o artigo 84, item IV, da Constituição Federal, e tendo em vista o que dispõe o artigo $8^{\circ}$, da Lei $n^{\circ}$ $6.902(1)$, de 27 de abril de 1981, a Lei $n^{\circ} 6.938(2)$, de 31 de agosto de 1981, e os Decretos $n^{\circ} s 88.351(3)$, de $1^{\circ}$ de junho de 1983 e Decreto $n^{\circ} 89.532(4)$, de 6 de abril de 1984.

DECRETA:

Art. $1^{\circ}$ Sob denominação de APA Cavernas do Peruaçu fica declarada Área de Proteção Ambiental, a região situada nos municípios de Januária e Itacarambi, no Estado de Minas Gerais, com as delimitações geográficas constantes do artigo $3^{\circ}$ deste Decreto.

Art. $2^{\circ} \mathrm{A}$ declaração de que trata o artigo anterior, além de garantir a conservação do conjunto paisagístico e da cultura regional, tem por objetivo proteger e preservar as cavernas e demais formações cársticas, sítios arqueopaleontológicos, a cobertura vegetal, a fauna silvestre onde há identificação de rotas de migração e sítios de arribação, cuja preservação é de fundamental importância para o ecossistema da Região.

Art. $3^{\circ} \mathrm{O}$ memorial descritivo da área que compreende a APA do rio Peruaçu foi elaborado com base nas cartas topográficas da Região Leste do Brasil, na escala de 1:100.000, do serviço geográfico do Exército, a saber: tem inicio à margem esquerda do rio São Francisco 700 (setecentos) metros a jusante da confluência com o rio Peruaçu; daí segue rumo nordeste passando pelo ponto cotado $451 \mathrm{~m}$, e seguindo na mesma direção até a referência de nivel de $460 \mathrm{~m}$ à margem da estrada que liga Januária a Itacarambi, próximo à Fazenda da Barraca; daí segue na direção nordeste, passando pelo ponto cotado $496 \mathrm{~m}$ até atingir, no topo do paredão calcário, o ponto cotado $671 \mathrm{~m}$ no divisor de águas entre duas sub-bacias, das quais a do córrego Olhos D'águas, ao sul, que fica incluída neste perímetro; daí segue o divisor de águas na direção oeste passando pelo ponto cotado $748 \mathrm{~m}$; daí segue na direção nordeste, sempre pelo divisor de águas da bacia hidrográfica do rio Peruaçu, passando, respectivamente, pelos pontos cotados $774 \mathrm{~m}, 788 \mathrm{~m}, 804 \mathrm{~m}, 787 \mathrm{~m}, 795 \mathrm{~m}, 786 \mathrm{~m}$, $776 \mathrm{~m}, 798 \mathrm{~m}$, e $776 \mathrm{~m}$; deste ponto cotado segue na direção oeste e oeste-nordeste, no divisor de águas da bacia do rio Peruaçu, com nome local de Serra das Missões passando pelos pontos cotados $771 \mathrm{~m}, 779 \mathrm{~m}, 787 \mathrm{~m}, 808 \mathrm{~m}, 801 \mathrm{~m}, 828 \mathrm{~m}, 818 \mathrm{~m}$, $812 \mathrm{~m}, 816 \mathrm{~m}, 805 \mathrm{~m}$, e $809 \mathrm{~m}$, respectivamente; dai segue, sempre pelo divisor de águas, na direção oeste passando pelos pontos cotados $808 \mathrm{~m}, 814 \mathrm{~m}, 812 \mathrm{~m}, 815 \mathrm{~m}$, $818 \mathrm{~m}, 796 \mathrm{~m}$, e $789 \mathrm{~m}$, respectivamente daí segue na direção sul passando por pontos cotados de mesma altitude $(816 \mathrm{~m})$ na regiäo denominada Tabuleiro; daí segue em direção a leste passando, respectivamente pelos pontos cotados $816 \mathrm{~m}$, e $808 \mathrm{~m}$; segue dai na região sudeste passando pelos pontos cotados $805 \mathrm{~m}, 801$, e $809 \mathrm{~m}$, respectivamente; segue daí rumo a leste até o ponto cotado de $812 \mathrm{~m}$; daí, seguindo sempre pelo divisor de águas da bacia do rio Peruaçu, rumo nordeste passando, respectivamente pelos pontos cotados $819 \mathrm{~m}$ e $823 \mathrm{~m}$; segue daí na direção sudeste passando, respectivamente, pelos pontos cotados $829 \mathrm{~m}, 829 \mathrm{~m}, 826 \mathrm{~m}$, e $832 \mathrm{~m}$; dai segue na direção oeste pelos pontos cotados $828 \mathrm{~m}, 822 \mathrm{~m}, 825 \mathrm{~m}$, e $824 \mathrm{~m}$, respectivamente; dai segue na direção nordeste passando pelos pontos cotados 
$788 \mathrm{~m}, 814 \mathrm{~m}, 833 \mathrm{~m}, 831 \mathrm{~m}$ e $788 \mathrm{~m}$, respectivamente; segue daí na direção sudeste passando, respectivamente, pelos pontos cotados $806 \mathrm{~m}, 786 \mathrm{~m}, 792$, e 753 ; daí segue no sentido sul passando pelos pontos cotados $788 \mathrm{~m}$ e $772 \mathrm{~m}$ respectivamente; daí segue na direção sudeste passando pelos pontos cotados $768,761 \mathrm{~m}, 768 \mathrm{~m}$ e $834 \mathrm{~m}$, respectivamente; segue dai, sempre acompanhando o divisor de águas da bacia do rio Peruaçu, atravessando a Serra da Mãe Joana, a leste, passando pelos pontos cotados $752 \mathrm{~m}, 522 \mathrm{~m}, 504 \mathrm{~m}, 488 \mathrm{~m}$ e $467 \mathrm{~m}$, respectivamente; daí segue na direção sudeste passando, respectivamente, pelos pontos cotados $552 \mathrm{~m}, 538 \mathrm{~m}$; daí segue em linha reta na direção leste até atingir a margem esquerda do rio São Francisco; deste ponto segue a jusante acompanhando a margem esquerda do rio São Francisco, passando pela foz do rio Peruaçu, até atingir o ponto onde teve início esta descrição.

Art. $4^{\circ} \mathrm{Na}$ implantação e funcionamento da APA Cavernas do Peruaçu serão adotadas, entre outras, as seguintes medidas:

1 - O procedimento de zoneamento da APA será realizado pelo Instituto Brasileiro do Meio Ambiente e dos Recursos Naturais Renováveis, do Ministério do Interior, que indicará as atividades a serem encorajadas em cada zona, bem como as que deverão ser limitadas, restringidas ou proibidas, de acordo com a legislação aplicável; objetivando a salvaguarda das Cavernas e demais formações cársticas, sítios arqueopaleontológicos e a biota nativa, para garantia das espécies, proteção dos habitats das espécies raras endêmicas, ameaçadas e em perigo de extinção.

II - A utilização dos instrumentos legais e dos incentivos financeiros governamentais, para assegurar a proteção da Zona de Vida Silvestre, o uso racional do solo e outras medidas referentes à salvaguarda dos recursos ambientais, sempre consideradas necessárias;

III - A aplicação, quando cabivel, de medidas legais, destinadas a impedir ou evitar o exercício de atividades causadoras de degradação da qualidade ambiental; em especial as atividades minerárias e agropecuárias;

IV A divulgação das medidas previstas neste Decreto, objetivando o esclarecimento da comunidade local sobre a APA e suas finalidades:

Art. $5^{\circ} \mathrm{Na}$ APA Cavernas do Peruaçu ficam proibidas ou restringidas:

I A implantação de atividades industriais potencialmente poluidoras, capazes de afetar mananciais de águas;

II A realização de obras de terraplenagem e a abertura de canais, quando essas iniciativas importarem em alteração das condições ecológicas locais, principalmente da Zona de Vida Silvestre, onde a biota será protegida com maior rigor;

III O exercício de atividades capazes de provocar erosão das terras ou assoreamento das coleções hídricas;

IV O exercicio de atividades que ameacem extinguir as espécies raras da biota, o patrimônio espeleológico e arqueológico, as manchas de vegetação primitiva e as nascentes de cursos d'água existentes na região;

$\mathrm{VO}$ uso de biocidas, quando indiscriminado ou em desacordo com as normas ou recomendações técnicas oficiais.

Art. $6^{\circ} \mathrm{A}$ abertura de vias de comunicações, de canais, barragens em cursos d'águas, a implantação de projetos de urbanização, sempre que importarem na realização de obras de terraplenagem, atividades minerárias, bem como a realização de grandes escavações e obras que causem alterações ambientais, dependerão da autorização prévia do Ibama, que somente poderá concedê-la:

I após estudo do projeto, exame das alternativas possiveis e a avaliação de suas 
conseqüências ambientais;

II mediante a indicação das restrições e medidas consideradas necessárias à salvaguarda dos ecossistemas atingidos;

Parágrafo único. As autorizações concedidas pelo lbama não dispensarão outras autorizações e licenças federais, estaduais e municipais porventura exigiveis.

Art. $7^{\circ}$ Para melhor controlar seus efluentes e reduzir o potencial poluidor das construções destinadas ao uso humano na APA Cavernas do Peruaçu, não serão permitidas:

1 - a construção de edificações em terrenos que, por suas características, não comportarem a existência simultânea de poços para receber o despejo de fossas sépticas, e de poços de abastecimento d'água, que fiquem a salvo de contaminação, quando não houver rede de coleta e estação de tratamento de esgoto em funcionamento;

II - a execução de projetos de urbanização, sem as devidas autorizações, alvarás, licenças federais, estaduais e municipais exigiveis.

Art. $8^{\circ}$ Os projetos de urbanização que, pelas suas características, possam provocar deslizamento do solo e outros processos erosivos, não terão a sua execução autorizada pelo Ibama.

Art. $9^{\circ} \mathrm{Em}$ casos de epidemia e endemias, veiculadas por animais silvestres, o Ministério da Saúde e a Secretaria de Saúde, do Estado de Minas Gerais, poderão, em articulação com o Ibama, promover programas especiais, para o controle dos referidos vetores.

Art. 10. Fica estabelecida na APA Cavernas do Peruaçu, uma Zona de Vida Silvestre destinada, prioritariamente, à salvaguarda das Cavernas e demais formações cársticas, sitios arqueo-paleontológicos e da biota nativa, para garantia da reprodução das espécies, proteção do habitat de espécies raras, endêmicas, em perigo ou ameaçadas de extinção.

Parágrafo único. A Zona de Vida Silvestre, de que trata o caput deste artigo, compreenderá as áreas mencionadas no artigo 18 , da Lei $n^{\circ} 6.938 / 81$, consideradas como de relevante interesse ecológico, ainda que de dominio privado, e ficarão sujeitas às restrições de uso e penalidades estabelecidas nos termos dos Decretos $n^{\circ} \mathrm{s} 88.351 / 83$ e $89.532 / 84$.

Art. 11. Visando à proteção de espécies raras na Zona de Vida Silvestre, não será permitida a construção de edificações, exceto as destinadas à realização de pesquisa e ao controle ambiental.

Art. 12. Na Zona de Vida Silvestre não será permitida atividade degradadora ou causadora de degradação ambiental, inclusive o porte de armas de fogo e de artefatos ou instrumentos de destruição da biota, ressalvados os casos objeto de prévia autorização, expedida em caráter excepcional pelo Ibama.

Art. 13. A APA Cavernas do Peruaçu será implantada, supervisionada, administrada e fiscalizada pelo Ibama, em articulação com o órgão estadual do meio ambiente de Minas Gerais, as prefeituras municipais dos municipios envolvidos e seus respectivos órgãos de meio ambiente.

Art. 14. Com vistas a atingir os objetivos previstos para a APA Cavernas do Peruaçu, bem como para definir as atribuições e competências no controle de suas atividades, - Ibama poderá firmar convênios com órgãos e entidades públicas ou privadas.

Art. 15. As penalidades previstas nas Leis $n^{\circ} \mathrm{S} 6.902 / 81$ e $6.938 / 81$ serão aplicadas 
aos transgressores das disposições deste Decreto, pelo Ibama, com vistas ao cumprimento das medidas preventivas e corretivas, necessárias à preservação da qualidade ambiental.

Parágrafo único. Dos atos e decisões do lbama, referentes a esta APA caberá recursos ao Conselho Nacional do Meio Ambiente - CONAMA.

Art. 16. Os investimentos e a concessão de financiamento e incentivos, da Administração Pública Federal, direta ou indireta, destinados à APA Caverna do Peruaçu serão previamente compatibilizados com as diretrizes estabelecidas neste Decreto.

Art. 17. O Ibama expedirá as instruções normativas necessárias ao cumprimento deste Decreto.

Art. 18. Este Decreto entra em vigor na data de sua publicação.

Art. 19. Revogam-se as disposições em contrário.

Brasilia, 26 de setembro de $1989 ; 168^{\circ}$ da Independência e $101^{\circ}$ da República. ANTÔNIO PAES DE ANDRADE

João Alves Filho 


\section{ANEXO G: DECRETO DE CRIAÇÃO DO PARNA CAVERNAS DO PERUAÇU}

\section{DECRETO DE 21 DE SETEMBRO DE 1999.}

Cria o Parque Nacional Cavernas do Peruaçu, no Estado de Minas Gerais, e dá outras providências.

O PRESIDENTE DA REPÚBLICA, no uso da atribuição que the confere o art. 84, inciso IV, e de acordo com o art. 225 , $\$ 1$, inciso III, da Constituiçăo, e tendo em vista o disposto no art. $5^{\circ}$ da Lei $n^{\circ} 4.771$, de 15 de setembro de 1965 ,

\section{DECRETA:}

Art . $1^{\circ}$ Fica criado, na região norte do Estado de Minas Gerais, o Parque Nacional Cavernas do Peruaçu, com o objetivo de proteger o patrimônio geológico e arqueológico, amostras representativas de cerrado, floresta estacional e demais formas de vegetação natural existentes, ecótonos e encraves entre estas formaçōes, a fauna, as paisagens, os recursos hidricos, e os demais atributos bióticos e abióticos da região.

Art $2^{\circ}$ O Parque Nacional Cavernas do Peruaçu tem os seguintes limites, descritos com base nas ortofotocartas planialtimétricas em escala 1:10.000 $\mathrm{n}^{\circ} \mathrm{s} 213385,213396,213387,213388,213395$, $213396,213397,213398,217804,217805,217806,217807,217813,217914,217815,217816,217817$ $217824,217825,217826,217835,217836,217837,217838,217846,217847,217856$, e 217857 , produzidas em 1991 pela Geonex para o Instituto Nacional de Colonização e Reforma Agrária - INCRA e Fundação Rural Mineira Colonização e Desenvolvimento Agrário - RURALMINAS. e nas cartas topográficas do Vale do Săo Francisco, em escala 1:50.000, produzidas por Serviços Aerofotogramétricos Cruzeiro do Sul para a SUVALE, em 1968, no S SD.23-Z-C-1l-1 (MI 2178-1), SD.23Z-C-II-2 (MI 2178-2), SD.23-Z-C-II-3 (MI 2178-3), e SD.23-Z-C-II-4 (MI 2178-4): começa na margem do rio São Francisco, no ponto de coordenadas planas aproximadas (c.p.a.) $592046 \mathrm{E}$ e $8312660 \mathrm{~N}$ (ponto 1); deste ponto [...] até atingir o ponto de c.p.a. $592168 \mathrm{E}$ e $8312547 \mathrm{~N}$ (ponto 412); daí, segue por linha reta até atingir o ponto de c.p.a. $592046 \mathrm{E}$ e $8312660 \mathrm{~N}$, ponto inicial desta descrição, fechando o perímetro do Parque Nacional e perfazendo uma área aproximada de 56.800 há (cinqùenta e seis mil e oitocentos hectares).

Art. $3^{0}$ As terras e benfeitorias localizadas dentro dos limites descritos no artigo anterior ficam declaradas de utilidade pública, para fins de desapropriação, pelo Instituto Brasileiro do Meio Ambiente e dos Recursos Naturais Renováveis - IBAMA, nos termos do Decreto-Lei $n^{\circ} 3.365$, de 21 de junho de 1941, alterado pela Lei $n^{\circ} 2.786$, de 21 de maio de 1956.

Parágrafo único. Ficam ressalvadas do disposto no caput deste artigo, as áreas constantes do Decreto de 29 de dezembro de 1994, declaradas de utilidade pública, para fins de desapropriaçăo, integrantes da Área de Proteção Ambiental Cavernas do Peruaçu, no Estado de Minas Gerais.

Art . $4^{\circ} \mathrm{O}$ Parque Nacional Cavernas do Peruaçu será administrado pelo IBAMA, que deverá tomar as medidas necessárias para sua efetiva implantação e controle.

Art . $5^{\circ}$ O Plano de Manejo do Parque Nacional Cavernas do Peruaçu deverá ser elaborado no prazo de cinco anos, a contar da publicaçăo deste Decreto.

Art . $6^{\circ}$ Este Decreto entra em vigor na data de sua publicação.

Brasilia, 21 de setembro de $1999 ; 178^{\circ}$ da Independência e $111^{\circ}$ da República.

\section{FERNANDO HENRIQUE CARDOSO}

José Sarney Filho. 
ANEXO H: RADIAÇÃO SOLAR MÉDIA MENSAL (M/Jm²) DE MINAS GERAIS (1961 $-1990)$.

\begin{tabular}{|c|c|c|c|c|c|c|c|c|c|c|c|c|}
\hline NOME & $\mathrm{JAN}$ & FEV & MAR & $A B R$ & $\mathrm{MAI}$ & JUN & JUL & $\mathrm{ASO}$ & SET & OUT & NOV & DEZ \\
\hline Aimorés & 42 & 40 & 37 & 32 & 27 & 25 & 26 & 29 & 34 & 39 & 41 & 42 \\
\hline Araçuaí & 41 & 40 & 37 & 33 & 28 & 26 & 27 & 30 & 35 & 39 & 41 & 41 \\
\hline Araxá & 42 & 40 & 37 & 32 & 27 & 25 & 25 & 29 & 34 & 39 & 41 & 42 \\
\hline Bambuí & 42 & 40 & 36 & 31 & 27 & 24 & 25 & 29 & 34 & 39 & 41 & 42 \\
\hline Barbacena & 42 & 40 & 36 & 31 & 26 & 24 & 25 & 29 & 34 & 38 & 41 & 42 \\
\hline B. Horizonte & 42 & 40 & 37 & 32 & 27 & 25 & 25 & 29 & 34 & 39 & 41 & 42 \\
\hline C. M. Dentro & 42 & 40 & 37 & 32 & 27 & 25 & 26 & 29 & 34 & 39 & 41 & 42 \\
\hline Caparaó & 42 & 40 & 36 & 31 & 26 & 24 & 25 & 29 & 34 & 39 & 41 & 42 \\
\hline Capinópolis & 42 & 40 & 37 & 32 & 27 & 25 & 26 & 30 & 34 & 39 & 41 & 42 \\
\hline Caratinga & 42 & 40 & 37 & 32 & 27 & 25 & 25 & 29 & 34 & 39 & 41 & 42 \\
\hline Cataguases & 42 & 40 & 36 & 31 & 26 & 24 & 25 & 29 & 34 & 38 & 41 & 42 \\
\hline C. Pacheco & 42 & 40 & 36 & 31 & 26 & 24 & 24 & 29 & 34 & 38 & 41 & 42 \\
\hline Diamantina & 42 & 40 & 37 & 32 & 27 & 25 & 26 & 30 & 34 & 39 & 41 & 42 \\
\hline Espinosa & 41 & 40 & 37 & 33 & 29 & 27 & 28 & 31 & 35 & 39 & 40 & 41 \\
\hline G.Valadares & 42 & 40 & 37 & 32 & 27 & 25 & 26 & 30 & 34 & 39 & 41 & 42 \\
\hline Ibirité & 42 & 40 & 36 & 31 & 27 & 24 & 25 & 29 & 34 & 39 & 41 & 42 \\
\hline Itamarandiba & 41 & 40 & 37 & 32 & 28 & 26 & 26 & 30 & 35 & 39 & 41 & 42 \\
\hline J.Pinheiro & 41 & 40 & 37 & 32 & 28 & 26 & 26 & 30 & 35 & 39 & 41 & 42 \\
\hline Juiz de Fora & 42 & 40 & 36 & 31 & 26 & 23 & 24 & 28 & 34 & 38 & 41 & 42 \\
\hline Lavras & 42 & 40 & 36 & 31 & 26 & 24 & 25 & 29 & 34 & 38 & 41 & 42 \\
\hline Machado & 42 & 40 & 36 & 31 & 26 & 24 & 24 & 29 & 34 & 38 & 41 & 42 \\
\hline Monte Azul & 41 & 40 & 37 & 33 & 29 & 27 & 28 & 31 & 35 & 39 & 40 & 41 \\
\hline M.Clatos & 41 & 40 & 37 & 33 & 28 & 26 & 27 & 31 & 35 & 39 & 41 & 41 \\
\hline Paracatu & 41 & 40 & 37 & 33 & 28 & 26 & 27 & 30 & 35 & 39 & 41 & 41 \\
\hline P. Minas & 42 & 40 & 37 & 32 & 27 & 25 & 26 & 30 & 34 & 39 & 41 & 42 \\
\hline Pedra Azul & 41 & 40 & 37 & 33 & 28 & 26 & 27 & 31 & 35 & 39 & 40 & 41 \\
\hline Pompeu & 42 & 40 & 37 & 32 & 27 & 25 & 26 & 29 & 34 & 39 & 41 & 42 \\
\hline S. Lourenço & 42 & 40 & 36 & 31 & 26 & 23 & 24 & 28 & 33 & 38 & 41 & 43 \\
\hline Sete Lagoas & 42 & 40 & 37 & 32 & 27 & 25 & 26 & 29 & 34 & 39 & 41 & 42 \\
\hline Teófilo Otoni & 41 & 40 & 37 & 32 & 28 & 26 & 26 & 30 & 35 & 39 & 41 & 42 \\
\hline Uberaba & 42 & 40 & 37 & 32 & 27 & 25 & 25 & 29 & 34 & 39 & 41 & 42 \\
\hline Viçosa & 42 & 40 & 36 & 31 & 26 & 24 & 25 & 29 & 34 & 39 & 41 & 42 \\
\hline
\end{tabular}

Fonte: INMET, 1992. 


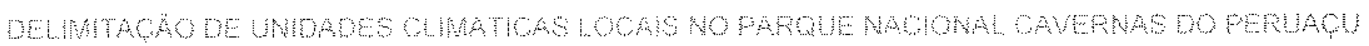
WERAO PEVGAOA

Sergin Serafm unto

ANEXO I: TEMPERATURA DO AR MÉDIA $\left({ }^{\circ} \mathrm{C}\right)$ MENSAL DE MINAS GERAIS (1961 - 1990).

\begin{tabular}{|c|c|c|c|c|c|c|c|c|c|c|c|c|}
\hline NOME & JAN & FEV & $\mathrm{MAR}$ & $\mathrm{ABR}$ & MAI & JuN & JUL & $\mathrm{AGO}$ & SET & OUT & NOV & $\mathrm{DEZ}$ \\
\hline Aimorés & 24,9 & 23,3 & 25,1 & 24,5 & 23,7 & 22,1 & 21,8 & 23,2 & 24,9 & 25,5 & 25,0 & 24,6 \\
\hline Araçuai & 24,4 & 24,7 & 24,7 & 23,9 & 23,3 & 22,1 & 22,1 & 23,2 & 24,9 & 25,5 & 24,9 & 24,5 \\
\hline Araxá & 23,7 & 23,9 & 23,9 & 22,7 & 21,4 & 19,9 & 19,5 & 20,3 & 21,4 & 22,6 & 22,9 & 23,2 \\
\hline Bambuí & 23,5 & 24,0 & 24,4 & 22,7 & 21,2 & 19,7 & 19,4 & 21,2 & 22,7 & 23,7 & 23,4 & 23,3 \\
\hline Barbacena & 25,7 & 26,5 & 26,1 & 25,0 & 23,4 & 22,0 & 21,2 & 23,1 & 24,7 & 25,4 & 25,1 & 25,1 \\
\hline B. Horizonte & 23,7 & 24,0 & 24,0 & 23,2 & 21,2 & 19,4 & 19,2 & 21,4 & 23,5 & 24,2 & 23,7 & 23,2 \\
\hline C. M. Dentro & 23,1 & 23,6 & 23,4 & 22,7 & 22,0 & 20,3 & 19,9 & 21,8 & 23,2 & 23,8 & 23,6 & 22,8 \\
\hline Caparaó & 21,6 & 21,8 & 21,7 & 20,3 & 23,8 & 17,1 & 16,3 & 17,6 & 18,9 & 20,5 & 20,8 & 21,2 \\
\hline Capinópolis & 24,8 & 24,6 & 24,9 & 23,4 & 20,6 & 20,1 & 19,5 & 20,4 & 21,8 & 22,9 & 23,6 & 22,4 \\
\hline Caratinga & 19,8 & 20,0 & 19,9 & 18,5 & 17,1 & 16,0 & 15,3 & 16,5 & 17,4 & 18,7 & 19,1 & 19,3 \\
\hline Cataguases & 22,1 & 22,2 & 22,9 & 21,2 & 19,7 & 18,5 & 18,2 & 20,3 & 22,1 & 22,2 & 22,0 & 21,7 \\
\hline C. Pacheco & 23,8 & 24,1 & 24,0 & 23,3 & 21,5 & 20,3 & 20,2 & 22,5 & 23,9 & 24,7 & 24,3 & 23,7 \\
\hline Diamantina & 26,6 & 26,9 & 26,4 & 26,4 & 23,1 & 21,6 & 21,5 & 22,7 & 24,5 & 24,7 & 25,1 & 25,7 \\
\hline Espinosa & 23,4 & 23,5 & 23,0 & 21,3 & 19,0 & 17,0 & 16,5 & 18,2 & 20,1 & 21,7 & 22,5 & 22,8 \\
\hline G.Valadares & 23,7 & 24,1 & 23,9 & 22,8 & 20,6 & 18,8 & 18,6 & 20,8 & 22,2 & 23,5 & 23,4 & 23,2 \\
\hline lbirité & 22,9 & 23,0 & 22,8 & 21,2 & 19,3 & 17,9 & 17,5 & 19,3 & 20,9 & 22,1 & 22,1 & 22,3 \\
\hline Itamarandiba & 26,6 & 27,1 & 26,7 & 25,2 & 23,6 & 21,7 & 21,3 & 22,5 & 23,5 & 25,0 & 25,5 & 26,0 \\
\hline J.Pinheiro & 21,7 & 22,2 & 22,0 & 20,7 & 19,2 & 17,9 & 17,5 & 19,4 & 20,5 & 21,4 & 21,3 & 21,1 \\
\hline Juiz de Fora & 23,6 & 23,4 & 23,3 & 21,6 & 20,1 & 18,6 & 18,5 & 20,9 & 22,6 & 23,2 & 23,1 & 23,4 \\
\hline Lavras & 23,5 & 23,9 & 23,4 & 21,7 & 19,8 & 18,3 & 18,0 & 19,1 & 20,4 & 22,0 & 22,6 & 21,9 \\
\hline Machado & 22,8 & 23,2 & 23,0 & 21,1 & 19,8 & 18,5 & 18,1 & 19,0 & 21,0 & 21,9 & 22,2 & 22,2 \\
\hline Monte Azul & 23,3 & 23,6 & 23,1 & 21,4 & 19,8 & 16,5 & 16,3 & 18,0 & 19,3 & 22,3 & 22,8 & 21,5 \\
\hline M.Claros & 22,6 & 22,9 & 22,5 & 22,4 & 18,0 & 16,9 & 16,5 & 18,4 & 20,5 & 21,7 & 22,0 & 22,1 \\
\hline Paracatu & 21,0 & 21,4 & 21,0 & 19,0 & 17,5 & 15,4 & 15,3 & 16,4 & 17,7 & 19,4 & 20,3 & 20,8 \\
\hline P. Minas & 22,1 & 22,3 & 21,8 & 20,0 & 17,7 & 16,0 & 15,4 & 16,9 & 18,3 & 20,2 & 20,2 & 21,3 \\
\hline Pedra Azul & 21,7 & 22,1 & 20,9 & 19,8 & 17,5 & 16,3 & 15,8 & 17,7 & 19,0 & 20,4 & 20,9 & 21,1 \\
\hline Pompeu & 20,3 & 20,6 & 20,0 & 18,3 & 16,4 & 15,2 & 14,7 & 16,0 & 17,1 & 18,3 & 19,0 & 19,5 \\
\hline S. Lourenço & 25,5 & 25,7 & 25,9 & 23,4 & 20,8 & 19,6 & 19,6 & 20,6 & 22,1 & 23,6 & 22,4 & 23,0 \\
\hline Sete Lagoas & 23,9 & 24,1 & 23,5 & 21,7 & 19,5 & 17,3 & 16,9 & 18,2 & 19,7 & 21,5 & 22,6 & 23,2 \\
\hline Teófilo Otoni & 22,1 & 22,4 & 21,8 & 20,1 & 17,4 & 16,1 & 15,6 & 17,6 & 19,4 & 20,7 & 20,9 & 21,6 \\
\hline Uberaba & 22,3 & 22,5 & 21,1 & 19,8 & 18,2 & 17,1 & 16,4 & 17,5 & 17,3 & 18,5 & 19,6 & 20,9 \\
\hline Viçosa & 22,1 & 22,4 & 21,6 & 19,5 & 16,4 & 14,5 & 13,7 & 16,3 & 18,7 & 20,4 & 21,2 & 22,4 \\
\hline
\end{tabular}

Fonte: INMET, 1992. 
ANEXO J: PLUVIOSIDADE ACUMULADA (mm) DE MINAS GERAIS (1961 - 1990).

\begin{tabular}{|c|c|c|c|c|c|c|c|c|c|c|c|c|}
\hline NOME & $\mathrm{JAN}$ & $\mathrm{FEV}$ & $M A R$ & $A B R$ & $\mathrm{MAI}$ & JUN & sul & AGO & SET & OUT & NOV & DEZ \\
\hline Aimorés & 68 & 66 & 67 & 64 & 60 & 57 & 54 & 48 & 48 & 55 & 64 & 69 \\
\hline Araçuaí & 72 & 70 & 69 & 73 & 62 & 58 & 55 & 51 & 52 & 56 & 66 & 71 \\
\hline Araxá & 75 & 72 & 74 & 75 & 75 & 72 & 73 & 70 & 69 & 72 & 75 & 77 \\
\hline Bambui & 74 & 71 & 73 & 72 & 65 & 65 & 59 & 52 & 53 & 62 & 76 & 77 \\
\hline Barbacena & 76 & 73 & 72 & 69 & 72 & 72 & 70 & 66 & 62 & 72 & 76 & 78 \\
\hline B. Horizonte & 89 & 78 & 79 & 77 & 76 & 74 & 64 & 64 & 63 & 69 & 76 & 82 \\
\hline C. M. Dentro & 78 & 76 & 75 & 73 & 69 & 67 & 64 & 58 & 59 & 68 & 74 & 79 \\
\hline Caparaó & 81 & 80 & 81 & 82 & 81 & 80 & 79 & 75 & 74 & 78 & 81 & 83 \\
\hline Capinópolis & 78 & 76 & 78 & 79 & 81 & 82 & 81 & 78 & 76 & 78 & 80 & 80 \\
\hline Caratinga & 80 & 76 & 79 & 80 & 78 & 76 & 73 & 70 & 72 & 75 & 80 & 82 \\
\hline Cataguases & 78 & 77 & 79 & 74 & 69 & 64 & 59 & 52 & 55 & 67 & 75 & 80 \\
\hline C. Pacheco & 85 & 83 & 83 & 80 & 78 & 75 & 70 & 67 & 69 & 73 & 79 & 85 \\
\hline Diamantina & 77 & 75 & 74 & 77 & 76 & 77 & 75 & 69 & 71 & 74 & 78 & 79 \\
\hline Espinosa & 76 & 75 & 78 & 79 & 80 & 79 & 75 & 71 & 69 & 73 & 76 & 78 \\
\hline G.Valadares & 80 & 78 & 79 & 79 & 78 & 76 & 72 & 69 & 68 & 73 & 79 & 83 \\
\hline Ibirité & 77 & 75 & 75 & 73 & 72 & 70 & 66 & 60 & 60 & 67 & 74 & 77 \\
\hline Itamarandiba & 80 & 78 & 79 & 78 & 76 & 73 & 72 & 71 & 78 & 78 & 80 & 84 \\
\hline J.Pinheiro & 82 & 82 & 82 & 80 & 77 & 74 & 71 & 67 & 70 & 76 & 81 & 85 \\
\hline Juiz de Fora & 81 & 81 & 80 & 76 & 75 & 73 & 67 & 59 & 63 & 71 & 75 & 80 \\
\hline Lavras & 81 & 79 & 81 & 82 & 83 & 83 & 81 & 77 & 80 & 77 & 80 & 82 \\
\hline Machado & 79 & 75 & 75 & 74 & 73 & 71 & 69 & 65 & 65 & 70 & 74 & 78 \\
\hline Monte Azul & 83 & 81 & 82 & 83 & 83 & 81 & 79 & 74 & 74 & 76 & 80 & 85 \\
\hline M.Claros & 79 & 78 & 78 & 78 & 78 & 77 & 74 & 69 & 68 & 72 & 76 & 80 \\
\hline Paracatu & 79 & 77 & 78 & 79 & 80 & 79 & 78 & 74 & 75 & 76 & 77 & 78 \\
\hline P. Minas & 82 & 81 & 82 & 83 & 83 & 84 & 82 & 77 & 76 & 77 & 81 & 83 \\
\hline Pedra Azul & 81 & 80 & 77 & 80 & 77 & 76 & 72 & 67 & 69 & 74 & 78 & 82 \\
\hline Pompeu & 83 & 85 & 83 & 84 & 82 & 81 & 79 & 75 & 77 & 81 & 84 & 85 \\
\hline S. Lourenço & 78 & 77 & 75 & 78 & 79 & 79 & 78 & 74 & 75 & 77 & 77 & 77 \\
\hline Sete Lagoas & 79 & 79 & 79 & 81 & 81 & 81 & 79 & 76 & 76 & 76 & 78 & 81 \\
\hline Teófilo Otoni & 77 & 76 & 76 & 75 & 75 & 73 & 69 & 64 & 64 & 70 & 73 & 77 \\
\hline Uberaba & 83 & 81 & 84 & 84 & 83 & 86 & 78 & 74 & 83 & 81 & 81 & 85 \\
\hline Viçosa & 80 & 77 & 79 & 79 & 80 & 78 & 76 & 71 & 70 & 75 & 75 & 79 \\
\hline
\end{tabular}

Fonte: INMET, 1992. 


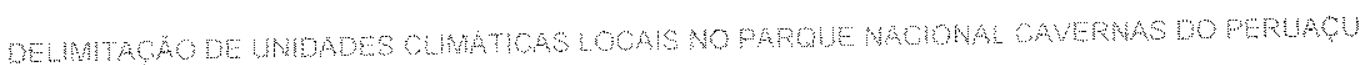

WERAOHEVADA

Serge Serant whot

ANEXO K: UMIDADE RELATIVA DO AR (\%) DE MINAS GERAIS (1961 - 1990).

\begin{tabular}{|c|c|c|c|c|c|c|c|c|c|c|c|c|}
\hline NOME & JAN & FEV & MAR & $\mathrm{ABR}$ & MAl & UUN & JuL & AGO & $S E T$ & OUT & NOV & $D E Z$ \\
\hline Aimorés & 68 & 66 & 67 & 64 & 60 & 57 & 54 & 48 & 48 & 55 & 64 & 69 \\
\hline Araçuaí & 72 & 70 & 69 & 73 & 62 & 58 & 55 & 51 & 52 & 56 & 66 & 71 \\
\hline Araxá & 75 & 72 & 74 & 75 & 75 & 72 & 73 & 70 & 69 & 72 & 75 & 77 \\
\hline Bambui & 74 & 71 & 73 & 72 & 65 & 65 & 59 & 52 & 53 & 62 & 76 & 77 \\
\hline Barbacena & 76 & 73 & 72 & 69 & 72 & 72 & 70 & 66 & 62 & 72 & 76 & 78 \\
\hline B. Horizonte & 89 & 78 & 79 & 77 & 76 & 74 & 64 & 64 & 63 & 69 & 76 & 82 \\
\hline C. M. Dentro & 78 & 76 & 75 & 73 & 69 & 67 & 64 & 58 & 59 & 68 & 74 & 79 \\
\hline Caparaó & 81 & 80 & 81 & 82 & 81 & 80 & 79 & 75 & 74 & 78 & 81 & 83 \\
\hline Capinópolis & 78 & 76 & 78 & 79 & 81 & 82 & 81 & 78 & 76 & 78 & 80 & 80 \\
\hline Caratinga & 80 & 76 & 79 & 80 & 78 & 76 & 73 & 70 & 72 & 75 & 80 & 82 \\
\hline Cataguases & 78 & 77 & 79 & 74 & 69 & 64 & 59 & 52 & 55 & 67 & 75 & 80 \\
\hline C. Pacheco & 85 & 83 & 83 & 80 & 78 & 75 & 70 & 67 & 69 & 73 & 79 & 85 \\
\hline Diamantina & 77 & 75 & 74 & 77 & 76 & 77 & 75 & 69 & 71 & 74 & 78 & 79 \\
\hline Espinosa & 76 & 75 & 78 & 79 & 80 & 79 & 75 & 71 & 69 & 73 & 76 & 78 \\
\hline G.Valadares & 80 & 78 & 79 & 79 & 78 & 76 & 72 & 69 & 68 & 73 & 79 & 83 \\
\hline Ibirité & 77 & 75 & 75 & 73 & 72 & 70 & 66 & 60 & 60 & 67 & 74 & 77 \\
\hline Itamarandiba & 80 & 78 & 79 & 78 & 76 & 73 & 72 & 71 & 78 & 78 & 80 & 84 \\
\hline J.Pinheiro & 82 & 82 & 82 & 80 & 77 & 74 & 71 & 67 & 70 & 76 & 81 & 85 \\
\hline Juiz de Fora & 81 & 81 & 80 & 76 & 75 & 73 & 67 & 59 & 63 & 71 & 75 & 80 \\
\hline Lavras & 81 & 79 & 81 & 82 & 83 & 83 & 81 & 77 & 80 & 77 & 80 & 82 \\
\hline Machado & 79 & 75 & 75 & 74 & 73 & 71 & 69 & 65 & 65 & 70 & 74 & 78 \\
\hline Monte Azul & 83 & 81 & 82 & 83 & 83 & 81 & 79 & 74 & 74 & 76 & 80 & 85 \\
\hline M.Claros & 79 & 78 & 78 & 78 & 78 & 77 & 74 & 69 & 68 & 72 & 76 & 80 \\
\hline Paracatu & 79 & 77 & 78 & 79 & 80 & 79 & 78 & 74 & 75 & 76 & 77 & 78 \\
\hline P. Minas & 82 & 81 & 82 & 83 & 83 & 84 & 82 & 77 & 76 & 77 & 81 & 83 \\
\hline Pedra Azul & 81 & 80 & 77 & 80 & 77 & 76 & 72 & 67 & 69 & 74 & 78 & 82 \\
\hline Pompeu & 83 & 85 & 83 & 84 & 82 & 81 & 79 & 75 & 77 & 81 & 84 & 85 \\
\hline S. Lourenço & 78 & 77 & 75 & 78 & 79 & 79 & 78 & 74 & 75 & 77 & 77 & 77 \\
\hline Sete Lagoas & 79 & 79 & 79 & 81 & 81 & 81 & 79 & 76 & 76 & 76 & 78 & 81 \\
\hline Teófilo Otoni & 77 & 76 & 76 & 75 & 75 & 73 & 69 & 64 & 64 & 70 & 73 & 77 \\
\hline Uberaba & 83 & 81 & 84 & 84 & 83 & 86 & 78 & 74 & 83 & 81 & 81 & 85 \\
\hline Viçosa & 80 & 77 & 79 & 79 & 80 & 78 & 76 & 71 & 70 & 75 & 75 & 79 \\
\hline
\end{tabular}

Fonte: INMET, 1992. 


\section{ANEXO L: LOCALIZAÇÃO DOS PONTOS DE AMOSTRAGEM E ASPECTOS GERAIS DO PARQUE NACIONAL CAVERNAS DO PERUAÇU.}

\begin{tabular}{|c|c|c|c|c|c|}
\hline PONTO & $\mathrm{UTM}(\mathrm{x})$ & UTM $\mathrm{Y}$ & $\begin{array}{l}\text { COMPARTIMENTO } \\
\text { GEOMORFOLOGICO } \\
\text { (IBAMA 2005) }\end{array}$ & $\begin{array}{l}\text { FISIONOMIA DO } \\
\text { RELEVO }\end{array}$ & $\begin{array}{l}\text { FISIONOMIA VEGETAL } \\
\text { (BAAMA, 2005). }\end{array}$ \\
\hline 01 & 598750 & 8347000 & CDSF & DEPRESSÃO & ANT \\
\hline 02 & 586250 & 8345250 & $\mathrm{CZT}$ & PLANALTO & FSA \\
\hline 03 & 591000 & 8340750 & $\mathrm{CC}$ & SERRA & FFL \\
\hline 04 & 576000 & 8339100 & $\mathrm{CC}$ & PLANALTO & ANT \\
\hline 05 & 585000 & 8338500 & $\mathrm{CZT}$ & PLANALTO & FSA \\
\hline 06 & 571750 & 8338250 & $\mathrm{CC}$ & PLANALTO & ANT \\
\hline 07 & 582000 & 8337750 & $\mathrm{CZT}$ & PLANALTO & ANT \\
\hline 08 & 596650 & 8336000 & CDSF & DEPRESSÃO & ANT \\
\hline 09 & 589250 & 8334750 & $\mathrm{CC}$ & SERRA & FFL \\
\hline 10 & 574500 & 8332000 & $\mathrm{CC}$ & PLANALTO & ANT \\
\hline 11 & 567250 & 8331500 & $\mathrm{CPG}$ & PLANALTO & FSA \\
\hline 12 & 578500 & 8331250 & $\mathrm{CC}$ & PLANALTO & $\mathrm{FFL}$ \\
\hline 13 & 579000 & 8329250 & $\mathrm{CC}$ & PLANALTO & ANT \\
\hline 14 & 581000 & 8329000 & $\mathrm{CC}$ & PLANALTO & FFL \\
\hline 15 & 593250 & 8329000 & CDSF & DEPRESSÄO & ANT \\
\hline 16 & 574000 & 8328000 & $\mathrm{CZT}$ & PLANALTO & FSA \\
\hline 17 & 579750 & 8327900 & $\mathrm{CC}$ & PLANALTO & $\mathrm{FFL}$ \\
\hline 18 & 582089 & 8327754 & $\mathrm{CC}$ & PLANALTO & $\mathrm{FFL}$ \\
\hline 19 & 577500 & 8327750 & CZT & PLANALTO & ANT \\
\hline 20 & 584500 & 8327650 & $\mathrm{CZT}$ & PLANALTO & ANT \\
\hline 21 & 585000 & 8326500 & $\mathrm{CC}$ & SERRA & $\mathrm{FFL}$ \\
\hline 23 & 581100 & 8325500 & $\mathrm{CC}$ & SERRA & $\mathrm{FFL}$ \\
\hline 24 & 576000 & 8325250 & $\mathrm{CZT}$ & PLANALTO & ANT \\
\hline 25 & 586500 & 8325000 & $\mathrm{CC}$ & SERRA & FSE \\
\hline 26 & 586600 & 8323250 & CDSF & DEPRESSÃO & ANT \\
\hline 27 & 595500 & 8323250 & CDSF & DEPRESSÃO & FSE \\
\hline 28 & 596000 & 8322750 & CDSF & DEPRESSÃO & FSE \\
\hline 29 & 581000 & 8322500 & $\mathrm{CC}$ & SERRA & $\mathrm{FFL}$ \\
\hline 30 & 573000 & 8322250 & $\mathrm{CC}$ & PLANALTO & FSA \\
\hline 31 & 585000 & 8321350 & CDSF & DEPRESSÃO & ANT \\
\hline 32 & 594750 & 8319750 & CDSF & DEPRESSÃO & FSE \\
\hline 33 & 580250 & 8318000 & $\mathrm{CC}$ & SERRA & ANT \\
\hline 34 & 585500 & 8317250 & CDSF & DEPRESSÃO & FSE \\
\hline 35 & 582750 & 8311000 & CDSF & DEPRESSÃO & ANT \\
\hline
\end{tabular}

Fonte: IBAMA (2005). 


\section{ANEXO M: UNIDADES DE PAISAGEM (GEOSSISTEMAS E GEOFÁCIES) DOS PONTOS DE AMOSTRAGEM DO PARQUE NACIONAL CAVERNAS DO PERUAÇU.}

\begin{tabular}{|c|c|c|c|c|}
\hline PONTO & $\mathrm{UTM}(x)$ & $\mathrm{UTMO}$ & GEOSSISTEMA & GEOFACIES \\
\hline 01 & 598750 & 8347000 & GDSF & GfAA \\
\hline 02 & 586250 & 8345250 & GPSF & GfSA \\
\hline 03 & 591000 & 8340750 & GSMC & GFFO \\
\hline 04 & 576000 & 8339100 & GPSF & GFAA \\
\hline 05 & 585000 & 8338500 & GPSF & GfSA \\
\hline 06 & 571750 & 8338250 & GPSF & GfAA \\
\hline 07 & 582000 & 8337750 & GPSF & GfAA \\
\hline 08 & 596650 & 8336000 & GDSF & GfAA \\
\hline 09 & 589250 & 8334750 & GSMC & GfFO \\
\hline 10 & 574500 & 8332000 & GPSF & GFAA \\
\hline 11 & 567250 & 8331500 & GPSF & GfSA \\
\hline 12 & 578500 & 8331250 & GPSF & GfAA \\
\hline 13 & 579000 & 8329250 & GPSF & GfAA \\
\hline 14 & 581000 & 8329000 & GPSF & GfFO \\
\hline 15 & 593250 & 8329000 & GDSF & GfAA \\
\hline 16 & 574000 & 8328000 & GPSF & GfSA \\
\hline 17 & 579750 & 8327900 & GPSF & GfFO \\
\hline 18 & 582089 & 8327754 & GSMC & GfFO \\
\hline 19 & 577500 & 8327750 & GPSF & GfAA \\
\hline 20 & 584500 & 8327650 & GSMC & GfSA \\
\hline 21 & 585000 & 8326500 & GSMC & GfFO \\
\hline 23 & 581100 & 8325500 & GSMC & GFFO \\
\hline 24 & 576000 & 8325250 & GPSF & GfAA \\
\hline 25 & 586500 & 8325000 & GSMC & GfSE \\
\hline 26 & 586600 & 8323250 & GDSF & GfAA \\
\hline 27 & 595500 & 8323250 & GDSF & GfSE \\
\hline 28 & 596000 & 8322750 & GDSF & GFSE \\
\hline 29 & 581000 & 8322500 & GSMC & GFFO \\
\hline 30 & 573000 & 8322250 & GSMC & GFAA \\
\hline 31 & 585000 & 8321350 & GDSF & GfAA \\
\hline 32 & 594750 & 8319750 & GDSF & GfSE \\
\hline 33 & 580250 & 8318000 & GSMC & GfAA \\
\hline 34 & 585500 & 8317250 & GDSF & GfAA \\
\hline 35 & 582750 & 8311000 & GDSF & GfAA \\
\hline
\end{tabular}

Fonte: IBAMA (2005). 
ANEXo N: VALORES MÉdios diáRIOS DE PRESSÃo ATMOSFÉRICA, NEBULOSIDADE, PLUVIOSIDADE, TEMPERATURA E UMIDADE RELATIVA DO AR, REGISTRADOS EM JULHO DE 2003.

\begin{tabular}{|c|c|c|c|c|c|}
\hline DA & $\begin{array}{l}\text { PRESSAO } \\
\text { ATMOSFERICA } \\
(\mathrm{hPa})\end{array}$ & $\begin{array}{r}\mathrm{NEBU}(O S D A D E \\
(\%)\end{array}$ & $\begin{array}{l}\text { PLMOSDADE } \\
(\mathrm{mm})\end{array}$ & $\begin{array}{l}\text { TEMPERATURA } \\
(\mathrm{C})\end{array}$ & $\begin{array}{l}\text { UMDADE, } \\
\text { RE ATNAC) }\end{array}$ \\
\hline 01 & 964 & 08 & 0 & 21,4 & 53 \\
\hline 02 & 963 & 13 & 0 & 23,5 & 49 \\
\hline 03 & 961 & 0 & 0 & 24,6 & 36 \\
\hline 05 & 960 & 0 & 0 & 18,2 & 62 \\
\hline 06 & 959 & 03 & 0 & 24,1 & 43 \\
\hline 07 & 960 & 01 & 0 & 24,3 & 46 \\
\hline 08 & 960 & 02 & 0 & 23,2 & 48 \\
\hline 09 & 959 & 0 & 0 & 26,4 & 45 \\
\hline 10 & 960 & 0 & 0 & 26,3 & 39 \\
\hline 11 & 960 & 01 & 0 & 26,7 & 37 \\
\hline 12 & 962 & 08 & 0 & 27,1 & 40 \\
\hline 13 & 963 & 49 & 0 & 22,8 & 59 \\
\hline 14 & 964 & 16 & 0 & 21,4 & 65 \\
\hline 15 & 964 & 34 & 0 & 24,7 & 47 \\
\hline 16 & 965 & 38 & 0 & 23,8 & 51 \\
\hline 17 & 965 & 26 & 0 & 23,1 & 55 \\
\hline 18 & 965 & 04 & 0 & 23,6 & 48 \\
\hline 19 & 965 & 09 & 0 & 24,2 & 42 \\
\hline 21 & 963 & 03 & 0 & 22,8 & 45 \\
\hline 22 & 963 & 70 & 0 & 23,3 & 60 \\
\hline 23 & 963 & 0 & 0 & 22,6 & 50 \\
\hline 24 & 963 & 35 & 0 & 25,0 & 49 \\
\hline 25 & 964 & 65 & 0 & 23,0 & 59 \\
\hline 26 & 964 & 38 & 0 & 24,7 & 53 \\
\hline 28 & 963 & 66 & 0 & 24,7 & 46 \\
\hline 29 & 963 & 66 & 0 & 24,2 & 45 \\
\hline 30 & 963 & 44 & 0 & 24,3 & 58 \\
\hline 31 & 961 & 54 & 0 & 23,2 & 52 \\
\hline
\end{tabular}

Fonte: Trabalho de campo (julho de 2003). 
ANEXO O: VALORES MÉDIOS DIÁRIOS DE PRESSÃO ATMOSFÉRICA, NEBULOSIDADE, PLUVIOSIDADE, TEMPERATURA E UMIDADE RELATIVA DO AR, REGISTRADOS EM JANEIRO DE 2004.

\begin{tabular}{|c|c|c|c|c|c|}
\hline $\mathrm{DA}$ & $\begin{array}{l}\text { PRESSAO } \\
\text { ATMOSFERICA } \\
\text { (BPa) }\end{array}$ & $\begin{array}{c}\text { NEBU OSDADE } \\
(\%)\end{array}$ & $\begin{array}{c}\text { PLUNOSIDADE } \\
\text { (mm) }\end{array}$ & $\begin{array}{l}\text { TEMPERATURA } \\
(\mathrm{C})\end{array}$ & $\begin{array}{l}\text { UMDADE } \\
\text { REIATIVA \%) }\end{array}$ \\
\hline 06 & 924 & $-\cdots$ & 0 & 32,9 & 46 \\
\hline 07 & 925 & - & 0 & 29,0 & 60 \\
\hline 08 & 925 & 82 & 0 & 27,9 & 70 \\
\hline 09 & 923 & 92 & 58 & 29,9 & 62 \\
\hline 10 & 923 & 88 & 14 & 25,4 & 85 \\
\hline 11 & 924 & 90 & 15 & 25,2 & 87 \\
\hline 12 & 924 & 100 & 11 & 24,8 & 90 \\
\hline 13 & 922 & 88 & 22 & 26,5 & 84 \\
\hline 14 & 922 & 90 & 27 & 26,0 & 86 \\
\hline 15 & 921 & 100 & 19 & 26,2 & 85 \\
\hline 16 & 921 & 98 & 29 & 24,9 & 93 \\
\hline 17 & 922 & 88 & 29 & 25,1 & 91 \\
\hline 18 & 924 & 100 & 04 & 24,6 & 88 \\
\hline 19 & 923 & 75 & 04 & 26,0 & 82 \\
\hline 20 & 924 & 39 & 01 & 25,4 & 81 \\
\hline 21 & 924 & 81 & 13 & 26,1 & 80 \\
\hline 22 & 922 & 95 & 07 & 24,4 & 93 \\
\hline 23 & 923 & 100 & 05 & 23,2 & 97 \\
\hline 24 & 925 & 91 & 0 & 24,6 & 88 \\
\hline 25 & 925 & 72 & 0 & 25,2 & 85 \\
\hline 26 & 925 & 74 & 0 & 25,6 & 83 \\
\hline 27 & 925 & 94 & 0 & 25,4 & 83 \\
\hline 28 & 925 & 75 & 03 & 25,7 & 74 \\
\hline 29 & 925 & 47 & 09 & 26,4 & 73 \\
\hline 30 & 920 & 38 & 01 & 26,9 & 70 \\
\hline 31 & -- & +-- & 0 & 21,6 & 82 \\
\hline
\end{tabular}

Fonte: Trabalho de campo (janeiro de 2004) 